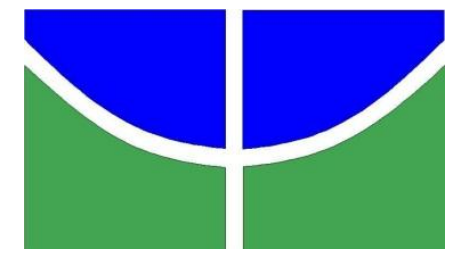

UNIVERSIDADE DE BRASÍLIA - UnB

FACULDADE DE COMUNICAÇÃO

PROGRAMA DE PÓS-GRADUAÇÃO

\title{
Comunicação Pública e Assistência Social: um estudo sobre os processos comunicativos nos Centros de Referência de Assistência Social/Cras
}

\author{
Kênia Augusta Figueiredo
}

Tese apresentada ao PPG/FAC para obtenção do grau de Doutor em Comunicação. Linha de Pesquisa: Políticas de Comunicação e Cultura. Orientadora: Prof. $^{\text {a }}$ Dr. ${ }^{\text {a }}$ Nélia Rodrigues Del Bianco 


\title{
Comunicação Pública e Assistência Social: um estudo sobre os processos comunicativos nos Centros de Referência de Assistência Social/Cras
}

\author{
Kênia Augusta Figueiredo
}

Tese apresentada ao PPG/FAC para obtenção do grau de Doutor em Comunicação. Linha de Pesquisa: Políticas de Comunicação e Cultura. Orientadora: Prof. ${ }^{\text {a }}$ Dr. ${ }^{\text {a }}$ Nélia Rodrigues Del Bianco

BRASÍLIA, FEVEREIRO DE 2016 
A tese Comunicação Pública e Assistência Social: um estudo sobre os processos comunicativos nos Centros de Referência de Assistência Social/Cras realizada pela doutoranda Kênia Augusta Figueiredo, aluna do Programa de Pós-Graduação da Faculdade de Comunicação da Universidade de Brasília foi aprovada em 26 de fevereiro de 2016, pela banca composta pelos seguintes membros:

Prof. ${ }^{\text {a Dr. }}{ }^{a}$ Nélia Rodrigues Del Bianco (orientadora)

Universidade de Brasília - Faculdade de Comunicação

Prof. ${ }^{\text {a }}$ Dr. ${ }^{\text {a }}$ Elen Cristina Geraldes

Universidade de Brasília - Faculdade de Comunicação

Prof. Dr. Jorge Antonio Menna Duarte

Empresa Brasileira de Pesquisa Agropecuária (Embrapa)

Prof. ${ }^{\text {a }}$ Dr. ${ }^{\text {a }}$ Elizabeth Pazito Brandão

FSBpesquisa

Dr. ${ }^{\text {a }}$ Marta Borba da Silva

Fasc - Fundação de Assistência Social e Cidadania/Prefeitura de Porto Alegre. 


\section{DEDICATÓRIA}

À memória de minha vó Fidalma Petraconni, filha de imigrantes italianos aportados no início do século XX, no Brasil, que com seu canto em meio ao seu ofício de lavadeira e o cuidado com suas netas nos ensinou a importância do trabalho, mas também, dado as dificuldades e pela ausência de, a necessidade do reconhecimento dos direitos sociais e a intervenção do Estado junto às famílias pobres.

A ela, assim como tantos trabalhadores de seu tempo que viram emergir as políticas sociais no Brasil e reconheceram, a partir de suas necessidades e não pela análise critica proporcionada pela dialética, Getúlio Vargas como o pai dos pobres.

Por ela, e a partir dela, meu desejo por um tempo em que a Comunicação Pública seja compreendida como parte do direito às políticas sociais e em sendo indissociável a comunicação e cultura se deflagre um processo de rompimento do mito fundador e finalmente os usuários das políticas sociais, em especial aqueles que utilizam a Assistência Social, ao se verem tratados como cidadãos não se sintam mais envergonhados, culpabilizados por sua situação e nem devedores de favores, uma vez que a exclusão social e a alienação são fundantes e inerentes ao capitalismo.

Nada justifica essa dor! 


\section{AGRADECIMENTOS}

Agradeço à minha orientadora Nélia Rodrigues Del Bianco pela disponibilidade e compromisso, sempre em busca de um trabalho coerente e realista, o que me possibilitou um amadurecimento intelectual, profissional e pessoal.

A Gustavo de Castro, Ellen Gerardes, Tiago Quiroga, Pedro Russi, Carlos Esch, Fernando Paulino e Murilo Ramos, professores da Faculdade de Comunicação (FACUnB) pela acolhida acadêmica e aprendizados.

Aos companheiros José Crus (pela disponibilidade fraterna), Simone Albuquerque e Jaime Rabelo Adriano por toda colaboração que me possibilitou realizar a pesquisa exploratória no âmbito da gestão nacional da Assistência Social e em consequência a pesquisa de campo.

Aos gestores municipais: Valdiosmar Vieira Santos, Marcelo Alves Mourão, Cleber Giovane Silveira pelo interesse e disponibilidade, o que permitiu um acesso tranquilo e profícuo às equipes técnicas e aos usuários dos Cras nos municípios de Tobias Barreto/SE, Belo Horizonte/MG e São Gabriel/RS.

A Edir Gomes de Morais Silva e Edvana Neres Cardoso, respectivamente gerentes de Proteção Social nos munícipios de Rubiataba/GO e Santarém/PA que me receberam sem um conhecimento prévio e indicações, viabilizando o contato com as equipes técnicas dos Cras e usuários.

A todos os trabalhadores que me receberam nos Cras, disponibilizando seu tempo, conhecimentos, curiosidade e confiança, transferindo suas legitimidades juntos aos usuários a fim de facilitar meu acesso a eles já que em geral é difícil a exposição, principalmente para os de etnia indígena.

Aos usuários dessa política, princípio, meio e fim de todo esse estudo, meu mais profundo agradecimento. Na memória do meu coração ficaram os registros de muitos olhares e gestos curiosos e afetivos, mas também daqueles apreensivos, mas impelidos por uma coragem solidária.

Além desses citados agradeço aos sujeitos que estão no meu cotidiano sem os quais essa tese estaria subtraída. Sem dúvida sem Solange Albernaz da Silva essa pesquisa não ocorreria nesse formato. Mais que financiar esse projeto, ela dedicou horas, companhia, trabalho, interesse e esteve junto a cada momento. Amor maior eu não poderia ter tido e melhor companheira também. Por vezes me sentia representada na figura enigmática de Dom Quixote com Sancho Pança por esse país afora em busca de 
algumas verdades. O melhor disso tudo é que com você Sol eu nunca estive só. Obrigada, eternamente!

Aos amigos de todas as horas Reginaldo Guiraldelli e Frederico Tavares, respectivamente professores do Serviço Social (UnB) e da Comunicação (UFOP) pelas horas que gastaram me ouvindo e contribuindo com as minhas análises sobre todo esse movimento que fiz. Amadurecimentos que só são possíveis de agradecer no exercício amoroso da amizade.

À minha rede de proteção social (tratam-se daquelas pessoas que sem elas ou suas decisões tudo seria muito mais difícil) meus agradecimentos especiais. São eles: Ana Luiza Figueiredo Pesce e Silva, pela cumplicidade diária que me motiva a querer ser seu melhor exemplo sempre; Minha mãe, por sua presença espiritualizada tão fundamental nesse processo e junto com meu pai pela iniciação e incentivos nos primórdios; Minha irmã Elizabeth Figueiredo (eternamente Betinha), sempre e por tudo; Aos queridos tios: Elton Vitoriano, Benedito e João Figueiredo e aos que já se foram: Enês, Elci e Eliane Vitoriano pelo amor humorado e carinhoso. A d. Alba, César e Gisele parte da minha família ampliada, pela torcida amorosa; À Emília Bandeira Gomes e à Maria da Luz Veras pelo suporte fundamental; Aos colegas do Departamento de Serviço Social que no colegiado do curso votaram a favor de minha liberação nesses dois últimos anos;

Aos mais que queridos amigos jornalistas que a todo instante me estimularam e apoiaram meu trabalho: Claúdia Sória, Diogo Adjuto, Noêmia Felix e Rafael Werkema.

À Helena Santiago pela cumplicidade nas cabeçadas iniciais na Fac.

À Yana Bieles pelo trabalho primoroso na transcrição das entrevistas e por sua amizade.

À Mione Sales, Jeferson Ruiz e Ana Lúcia Vaz pela oportunidade do debate e das parcerias.

À Elaine Behring pela certeza de que só estou aqui porque estive lá. Sem seus primeiros incentivos e apoio é provável que nada disso estivesse acontecendo.

À Beth Pires (não só pelos primórdios), Brígida Andrade, Eliseu Custódio, Gladys Carvalho, Lena Alves, Rodolfo Alexandre Cascão Inácio, Rodrigo Furtini e os arte mobilizadores: Janaína, Lucas e Fernanda pelo aprendizado de que "sonho que se sonha só / É só um sonho que se sonha só / Mas sonho que se sonha junto é realidade".

À Isabel Goes pelo apoio e disponibilidade no agreste sergipano. 
Aos colegas nas disciplinas obrigatórias: Cecilia Bizerra, Gisele Pimenta, Ligia Lopes, Sérgio Maggio por tudo que compartilhamos e ainda por eu ter aprendido "o que é Leno?” A ele, Leno Veras meus agradecimentos.

Aos companheiros do conjunto CFESS-CRESS: Carla Alexandra, Cristiano Carvalho, Leonardo David, Rosilene Tavares, Thiago Alcântara, Viviane Arcanjo e aos colegas da Assistência Social: Léa Braga, Márcia Pinheiro, Maria José de Freitas, Renato de Paula (super obrigada!), Simone Almeida e Valéria Gonelli.

À Rosa Stein e Ângela Neves pelo carinho, preocupações e contribuições acadêmicas.

Aos queridos Joaquim Lavarini e Carolina Garcia Ribeiro pela parceria e desvelamentos.

Aos amigos que somam: Alziane Amadja da Silva, Andreia de Oliveira, Arlane Oliveira, Bene Régis Figueiredo, Daniel Filho, Denise Costa, Fábio Gabriel, Fabrícia Maciel, Fátima Elizabeth da Silva, Ivanete Boschetti, Lafaiete Dias Mota, Márcia Mendonça, Marcos Fontoura, Maria Vera Lucia Horta (exemplo de força, carinho e determinação), Mariana Barros, Marlene Alves Morocini, Marise Ruperto, Maurilio Matos, Renata Grisoli, Rodriane Oliveira Souza, Valdenizia Peixoto, Yene Christie Figueiredo (pela dose de pragmatismo).

Aos queridos alunos e alunas da disciplina de estágio no ano de 2013 que tanto contribuíram e me incentivaram: Árina Cyntia Costa, Daniel Ferraz, Debora Avelino, Deysianne Oliveira, Fernanda Câmara, Fernanda Carreiro, Jéssica Bevilaqua, Mariana Sousa, Neiva Lopes, Stela Amarante.

À ex-aluna Flávia Falcão da Gama Carvalho pela constante presença e cumplicidade com o tema comunicação e Serviço Social.

Aos membros da banca pela disponibilidade, interesse e contribuições que não se encerram nessa etapa.

Ao Lucas Morais pela revisão companheira na reta final.

Aos funcionários da pós-graduação da FAC e do Departamento de Serviço Social meus agradecimentos.

Valeu a pena! 
"Mudar o mundo,

Meu amigo Sancho,

Não é loucura,

Não é utopia,

É justiça"

(M. Cervantes) 


\section{RESUMO}

Essa tese aborda a comunicação pública aplicada no âmbito do Sistema Único de Assistência Social/Suas com o objetivo de analisar as características, práticas, ações, planos e estratégias de comunicação desenvolvidas pelos Centros de Referencia de Assistência Social/Cras no atendimento ao cidadão, tendo como referencia as principais características e funções clássicas do conceito de Comunicação Pública. A pesquisa foi estruturada com base no método dialético, utilizando técnicas como a observação direta e entrevistas estruturadas, aplicadas junto aos técnicos e usuários dos Cras, em cinco munícipios de porte habitacional diferenciado, nas cinco regiões do país. O estudo apontou que sob a égide do neoliberalismo as disputas na sociedade refletidas no âmbito do Estado influenciam a política de Assistência Social e a Comunicação Pública, em decorrência da relação com a questão social, comprometendo o direito a comunicação dos usuários, a democracia e a cidadania. A tese evidencia ainda que a Comunicação de Governo e a Comunicação Pública quando complementares legitima a política, mas, nesse caso é pouco praticada nas esferas de governo. Contudo, a Comunicação Pública, em que pese às precariedades das condições objetivas e subjetivas que retroalimentam a subalternidade de usuários, técnicos e gestores se manifesta na Assistência Social por meio dos tipos e formas que a caracteriza.

Palavras Chave: Comunicação Pública; Assistência Social; Política Pública; Centro de Referência de Assistência Social - Cras. 


\begin{abstract}
This thesis is about the public communication in the "Unified system of social assistance/USSA » with the goal to analyze the characteristics, practices, actions, plans and strategies of communications developed by the Center of References of Social Assistances/ CRSA in the services provides to the citizens, with references to the principal characteristics and classic functions in the concept of public communication. The research was based on the dialectical method, using techniques such as direct observation and structured interviews, done with the professionals and the public of the CRSA, in five municipalities of different sizes, in five regions of the country. The study showed that under the dominance of neoliberalism, public discourse reflected in the action of the State influences the policies of social assistance policy and public communication, as concerns the social question, resulting a negative impact on the rights of users, on democracy and on citizenship. The thesis also shows that if Government communication and public communication are complementary, this can legitimize policies, but that happens rarely in the sphere of Government. However, there is a common denominator of types and forms that characterize public communication in social assistance, due to precariousness of the objective and subjective conditions that determine the subordinate status of users, technicians and managers.
\end{abstract}

Keywords: Public Communications; Social Assistance; public policy; Center of References of Social Assistances/ CRSA. 


\section{RÉSUMÉ}

Cette thèse cherche à comprendre la communication publique mise en place par le Système Unique d'Assistance Social/SUAS. L'objectif est d'analyser les caractéristiques, les pratiques, les actions, les projets et les stratégies de communication développés par les Centres de Référence d'Assistance Sociale /CRAS d'accueil aux citoyens à partir des principales caractéristiques et des fonctions classiques de la notion de communication publique. La recherche a utilisée la méthode dialectique, adoptant des techniques de terrain comme l'observation directe et les entretiens approfondis auprès des techniciens et des usagers du CRAS en cinq villes de taille variée dans les cinq régions du Brésil. L'étude indique que, en conséquence de la politique néolibéral de l'Etat brésilien, les conflits de la société se reflètent dans la sphère de l'Etat et influencent la politique d'Assistance Sociale et la Communication Publique, ce que met en péril le droit à la communication des usagers du service, la démocratie et la citoyenneté. La thèse signale encore que lorsque la communication de l'Etat et la communication publique sont complémentaires, ce qui est rare, cela légitime la politique publique adoptée. Cependant, la communication publique au sein de l'Assistance Sociale au Brésil présente des caractéristiques et des catégories singulières, malgré la précarité des conditions objectives et subjectives qui caractérisent les usagers et les techniciens du SUAS.

Mots-clés: Communication Publique; L'aide Sociale ; La politique publique ; Centres de Référence d'Assistance Sociale /CRAS. 


\section{Lista de Tabelas}

Tabela 1. Trabalhadores da Assistência Social - tipo de vínculo profissional, p. 20.

Tabela 2. Trabalhadores da Assistência Social - formação profissional, p. 21.

Tabela 3. Trabalhadores nos Cras, por região do país, p. 90.

Tabela 4. Principais temáticas abordadas nos grupos do Paif, p. 129.

\section{Lista de Quadros}

Quadro 1. Profissões de nível superior no Suas, p. 21.

Quadro 2. Porte dos municípios, p. 41.

Quadro 3. Municípios e regiões visitadas, p. 42.

Quadro 4. Sobre as normativas e orientações referências no Suas, p. 79.

Quadro 5. Padrão de Qualidade do atendimento, p. 88.

\section{Lista de Figuras}

Figura 1. Estrutura organizacional da política de Assistência Social no âmbito federal, p. 76.

Figura 2. Estrutura organizacional da política de Assistência Social no âmbito estadual, p. 77.

Figura 3. Estrutura organizacional da política de Assistência Social no âmbito municipal, p. 78.

Figura 4. Escala de Risco para atendimento no Suas, p. 81.

Figura 5. Proteção social básica no território. O Cras e a rede de serviços socioassistenciais, p. 84.

Figura 6. Cras: unidade pública que abriga os serviços de prestação continuada (Paif), p. 85.

Figura 7. Síntese da política de Assistência Social, p. 91.

Figura 8. Folder, com duas dobras. 1a, $5^{\mathrm{a}}$ e $6^{\mathrm{a}}$ página Cras Menino Jesus. São Gabriel/RS, p. 124.

Figura 9. Folder, com duas dobras. $2^{\mathrm{a}}, 3^{\mathrm{a}}$ e $4^{\mathrm{a}}$ página. Cras Menino Jesus. São Gabriel/RS, p. 125. 
Figura 10. Cartão do usuário. Uma dobra. $1^{\mathrm{a}}$ e $4^{\mathrm{a}}$ página. Santarém/PA, p. 126.

Figura 11. Folder, uma dobra. $1^{\mathrm{a}}$ e $4^{\mathrm{a}}$ página. Cras Tobias Barreto/SE, p. 140.

Figura 12. Folder, com uma dobra. $2^{\mathrm{a}}$ e $3^{\mathrm{a}}$ página. Cras Tobias Barreto/SE, p. 141.

Figura 13. Lembrete da próxima reunião. Cras Menino Jesus. São Gabriel/RS, p. 143.

\section{Lista de Fotos}

Foto 1. Recepção do Cras Ribeirinho onde também é realizado o cadastro no Programa Bolsa Família. Santarém/PA, p. 116.

Foto 2. Recepção Cras II - Tobias Barreto/SE, p. 116.

Foto 3. Faixada externa do Cras Menino Jesus. São Gabriel/RS, p. 117.

Foto 4. Faixada externa do Cras Ribeirinho. Santarém/PA, p. 118.

Foto 5. Identificação do equipamento no Muro interno do Cras de Rubiataba/GO, p. 119.

Foto 6. Placa de identificação do Cras Urumari de acordo com as normativas do MDS, p. 120.

Foto 7. Automóvel da Proteção Social Básica compartilhado pelos Cras em Santarém/PA, p. 122.

Foto 8. Recepção do Cras Menino Jesus com televisão e equipe uniformizada, p. 123.

Foto 9. Oficina de Música. Cras Menino Jesus. São Gabriel/RS, p. 128.

Foto 10. Oficina de costura industrial. Rubiataba/GO, p. 128.

Foto 11. Grupo de Teatro de Mobilização Social - MOBS apresentando à uma comunidade o que é o Cras (2009), p. 149.

Foto 12. Corredor principal do Cras Menino Jesus. São Gabriel/RS, p. 156.

Foto 13. Informativos afixados nas paredes do Cras em Tobias Barreto/SE, p. 156. 


\section{Lista de Siglas}

Abepss - Associação Brasileira de Ensino e Pesquisa em Serviço Social

ABNT - Associação Brasileira de Normas Técnicas

BSP - Benefício para Superação da Extrema Pobreza

BVG - Variável gestante

BVJ - Variável vinculado ao adolescente

BVN - Variável nutriz

BPC - Beneficio de Prestação Continuada

BSM - Plano Brasil Sem Miséria

CAC - Centro de Desenvolvimento Urbano/ Centro de Apoio Comunitário

CadÚnico - Cadastro Único

CE - Ceará

CEAS - Conselho Estadual de Assistência Social

Cef - Caixa Econômica Federal

CF-88 - Constituição Federal de 1988

Cfess - Conselho Federal de Serviço Social

CapacitaSuas - Programa de Capacitação da Assistência Social

CEAS - Conselho estadual de Assistência Social

CIB - Comissão Intergestora Bipartite

CIT - Comissão de Intergestores tripartite

CMAS - Conselho Municipal de Assistência Social

CNAS - Conselho Nacional de Assistência Social

Confecom - Conferência Nacional de Comunicação

Congemas - Colegiado Nacional de Gestores Municipais de Assistência Social

Cras - Centro de Referencia de Assistência Social

Creas - Centro de Referência Especializado de Assistência Social

DOU - Diário Oficial da União

FEAS - Fundo Estadual de Assistência Social

Fiocruz - Fundação Osvaldo Cruz

FMI - Fundo Monetário Internacional

FNAS - Fundo Nacional de Assistência Social

FNLDC - Frente Nacional de Luta pela Democratização da Comunicação

FNDC - Fórum Nacional pela Democratização da Comunicação 
GO - Goiás

Intervozes - Coletivo Brasil de Comunicação Social

Lai - Lei de Acesso à Informação

LBA - Legião Brasileira de Assistência

Loas - Lei Orgânica da Assistência Social

MDS - Ministério do Desenvolvimento Social e Combate à Fome

MG - Minas Gerais

NOB/RH - Norma Operacional Básica de Recursos Humanos

NOB/Suas - Norma Operacional Básica do SUAS

OMC - Organização Mundial do Comércio

PA - Pará

Paif - Serviço de Proteção e Atendimento Integral à Família

PB - Paraíba

PBF - Programa Bolsa Família

PF - Polícia Federal

PIB - Produto Interno Bruto

PNAS - Política Nacional de Assistência Social

PSB - Proteção Social Básica

PSE - Proteção Social Especial

PSE Alta - Proteção social especial de alta complexidade

PSE Média - Proteção social especial de média complexidade

RS - Rio Grande do Sul

SE - Sergipe

SP - São Paulo

Suas - Sistema Único de Assistência Social

UIT - União Internacional de Telecomunicações

UnB - Universidade de Brasília

Unesco - Organização das Nações Unidas para a Educação, a Ciência e a Cultura 


\section{SUMÁRIO}

INTRODUÇÃO ............................................................................................................................ 1

CAPÍTULO 1

O percurso metodológico da pesquisa ................................................................................ 10

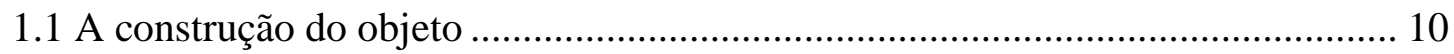

$1.2 \mathrm{O}$ referencial teórico metodológico da pesquisa .................................................. 17

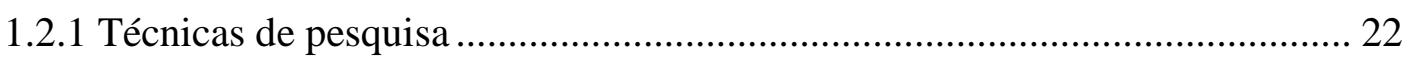

1.2.2 Campo de pesquisa .................................................................................. 24

CAPÍTULO 2

As categorias de análise da pesquisa................................................................................ 299

CAPÍTULO 3

Assistência social: uma política em movimento............................................................ 566

3.1 Sistema Único de Assistência Social: estrutura e organização............................. 599

CAPÍTULO 4

Comunicação Pública: uma unidade técnico-ético-política da comunicação......... 788

4.1 Comunicação Pública: tipos, singularidades e as formas de sua prática ............ 911

\section{CAPÍtUlO 5}

Comunicação Pública e Assistência Social: compatibilidades e contradições ...... 988

5.1 O Cras e o atendimento ao usuário ....................................................................... 988

5.2 A Comunicação Pública nos Cras.................................................................. 1199

5.2.1 Comunicação na Assistência Social: totalidades que desafiam um todo ..... 120

5.2.2 Os técnicos e a Comunicação Pública nos Cras ........................................... 1255

5.2.3 Os usuários nos Cras e a Comunicação Pública.......................................... 1388

CONSIDERAÇÕES FINAIS............................................................................... 1522

REFERÊNCIAS ............................................................................................... 1633

ANEXOS …….............................................................................................................. 1799 


\section{INTRODUÇÃO}

Esta tese aborda a Comunicação Pública aplicada no âmbito do Sistema Único de Assistência Social (Suas). O objetivo é analisar, tendo como referência as principais características e funções clássicas do conceito de Comunicação Pública, as características, as práticas, as ações, os planos e as estratégias de comunicação desenvolvidos pelos Centros de Referência de Assistência Social (Cras) no atendimento ao cidadão. A importância desse tema se deve a questões que se relacionam entre si e que decorrem do atual estágio do capitalismo, que aprofunda a desigualdade social e exige, por parte do Estado, mediações como as políticas sociais e a garantia de novas formas de participação do cidadão. Tal exigência se dá em virtude do amadurecimento do processo democrático no país, assim como a centralidade da comunicação na vida dos sujeitos na contemporaneidade.

No Brasil, embora a Constituição Federal (CF) de 1988, no tripé da Seguridade Social, ${ }^{1}$ tenha elevado a Assistência Social ao patamar de política pública, foi somente a partir de 2004 que o Sistema Único de Assistência Social (Suas) foi implementado. Seu objetivo é operacionalizar as ações de assistência social destinadas aos indivíduos que não têm condições de prover o próprio sustento de forma permanente ou provisória, independentemente de contribuição à Seguridade Social. Compete, portanto, à Assistência Social prover as necessidades básicas de indivíduos, famílias, gestantes e nutrizes, crianças, adolescentes, idosos e pessoas portadoras de deficiência que dela necessitar.

Atualmente, na Assistência Social são investidos cerca de 75,4 bilhões de reais, indicando um crescimento real de $600 \%$ entre 2003 e $2014 .^{2}$ Esse recurso financeiro é

\footnotetext{
${ }^{1}$ O tripé da Seguridade Social no Brasil, instituído pela Constituição Federal de 1988, no Título VIII sobre a Ordem Social, apresenta, entre os artigos 194 a 204, a base da regulamentação da área. Afirma que a proteção social no país é constituída pela Previdência Social prestada mediante contribuição; Assistência Social assegurada a quem dela necessitar de forma gratuita; e Saúde pública destinada a promover redução de risco de doenças e acesso a serviços básicos de saúde e saneamento.

${ }^{2}$ Informações obtidas no site "Dialoga Brasil" criado pelo governo federal em 28/07/2015 que tem por objetivo ser um canal de comunicação com a população na internet. $\mathrm{O}$ site foi criado para estimular a participação digital nas atividades governamentais e permite indicações de propostas para áreas prioritárias do governo, tais como: saúde; educação; segurança pública e redução da pobreza, perfazendo 14 temas e 80 programas. Nessa plataforma o cidadão pode fazer sugestões, votar nas propostas de outros participantes, conhecer as propostas do governo e ter acesso, em horário pré-estabelecidos, a bate-papos virtuais com ministros das áreas indicadas. Ao final do processo, indicado para novembro de 2016, o governo começará a responder às três propostas mais apoiadas de cada programa. Na operacionalização da plataforma são fornecidos dados e informações a respeito da área para o participante, os quais
} 
aplicado: na transferência de renda para 14 milhões $^{3}$ de famílias beneficiárias do Programa Bolsa Família; ${ }^{4}$ no repasse financeiro do Beneficio de Prestação Continuada ${ }^{5}$ a 4,1 milhões de pessoas com deficiência física e/ou mental ou com mais de 65 anos cuja renda per capita mensal seja de 1/4 do salário mínimo; e na prestação de serviços socioassistenciais de Proteção Social Básica (PSB) e de Proteção Especial (PSE) executados em equipamentos nos municípios vinculados ao Suas.

Os serviços socioassistenciais de proteção social básica são de base municipal e instalados em territórios identificados pelo órgão gestor da Assistência Social como áreas de vulnerabilidade social, ${ }^{6}$ sendo destinados às populações que vivem em risco pessoal e social decorrente da pobreza, privação e/ou fragilização de vínculos afetivos relacionais e de pertencimento social (discriminações etárias, étnicas, de gênero ou por deficiências, dentre outras). Com vistas ao gerenciamento e oferta desses serviços foram instituídos os Centros de Referência da Assistência Social, que funcionam como a principal porta de entrada do sistema nesse nível de atendimento. Os Cras, de acordo com a Política Nacional de Assistência Social (PNAS) de 2004, é uma unidade pública estatal de base territorial, responsável pela coordenação e organização da rede de serviços socioassistenciais local e pela execução de serviços de proteção social básica, sendo esta oferta de serviços no equipamento condicionada às condições do espaço físico, materiais e de recursos humanos da unidade.

utilizamos nesta introdução para caracterizar a dimensão da Assistência Social brasileira na atualidade. Disponível em: <http://dialoga.gov.br/\#/artigo/108073>. Acesso em: 12 ago. 2015.

${ }^{3}$ Dado extraído do Relatório de Gestão de 2014. Disponível em:

<http://www.mds.gov.br/webarquivos/arquivo/bolsa_familia/senarc/RelatorioGestao2014.pdf>.

Acesso em: 21 jan. 2016.

${ }^{4}$ Programa de transferência direta de renda, que beneficia famílias em situação de pobreza e de extrema pobreza em todo o país. Outras informações estão presentes no capítulo 3 desta tese.

5 O Beneficio de Prestação Continuada da Assistência Social (BPC) foi instituído pela Constituição Federal de 1988. Outras informações estão presentes no capítulo 3 desta tese.

${ }^{6}$ Não há um significado único para o termo de vulnerabilidade social. Trata-se de um conceito complexo e multifacetado, como afirma a publicação do Ministério do Desenvolvimento Social e Combate a Fome (MDS), “Orientações Técnicas sobre o Paif, vol. 1, 2012, p. 12 a 15”. Nesse documento, disponível no site do MDS, há uma breve sistematização do conceito desenvolvido e utilizado por pesquisadores e instituições públicas como o DIEESE, que caminham na direção de compreender que: a vulnerabilidade não é sinônimo de pobreza, mas é condição para agravar a vulnerabilidade das famílias; a vulnerabilidade não se trata de um estado, mas de uma condição dada na qual se pode atravessar, recair, permanecer ao longo da vida; a vulnerabilidade é um fenômeno que não se manifesta da mesma forma, o que exige análises especializadas tanto para a sua apreensão quanto para o enfrentamento; ela tende a gerar ciclos intergeracionais; e, as situações de vulnerabilidade social não prevenidas ou enfrentadas podem se transformar em uma situação de risco.

Disponível em:

<http://www.mds.gov.br/webarquivos/publicacao/assistencia_social/Cadernos/Orientacoes_PAIF_1.pdf>. Acesso em: 21 jan. 2016. 
Todos os Cras devem desempenhar as funções de gestor da proteção básica no seu território e ofertar o Serviço de Proteção e Atendimento Integral à Família (PAIF), que consiste na oferta de ações e serviços socioassistenciais de prestação continuada com vistas a prevenir o rompimento dos vínculos familiares e a violência no âmbito de suas relações. Dessa forma, em todos os Cras são realizados os seguintes serviços: 1) acolhida; 2) estudo da situação social dos indivíduos e das famílias; 3) visita domiciliar; 4) orientação e encaminhamentos; 5) grupos de famílias; 6) acompanhamento familiar; 7) atividades comunitárias; 8) campanhas socioeducativas; 9) informação, comunicação e defesa de direitos; 10) promoção do acesso à documentação pessoal; 11) mobilização e fortalecimento de redes sociais de apoio; desenvolvimento do convívio familiar e comunitário; mobilização para a cidadania; 12) conhecimento do território; 13) cadastramento socioeconômico; 14) elaboração de relatórios e/ou prontuários; 15) notificação da ocorrência de situações de vulnerabilidade e risco social; 16) busca ativa de pessoas com perfil da política de Assistência Social.

De acordo com o Censo Suas/Cras 2014, existem 8.088 centros de referência de assistência social em todo o Brasil em áreas de concentração de pobreza e de vulnerabilidade social. Além desses equipamentos públicos fixos, existem 1.384 equipes volantes que chegam às comunidades mais longínquas, sendo que, destas, 184 utilizam embarcações que levam o atendimento a ribeirinhos, a indígenas, a quilombolas, a pescadores artesanais, a extrativistas, a pantaneiros e outros.

Os serviços socioassistenciais da proteção especial são ofertados pelos Centros de Referência Especializado de Assistência Social (Creas) às famílias que enfrentam situações de maior risco social ou pessoal, tais como a exploração sexual, o trabalho infantil ou a violência doméstica, sendo assegurados atendimentos individualizados e com privacidade. De acordo com o Censo Suas 2014, atualmente existem 2.370 Creas em todo o país, sendo que 425 unidades trabalham especialmente com a população que mora na rua. Nesses equipamentos, a pessoa atendida pode guardar seus pertences, fazer higiene pessoal, participar de oficinas e receber orientações, além de ser incluída no Cadastro Único ${ }^{7}$ a fim de acessar outros programas sociais. Para esse público, a Assistência Social oferece também serviços de acolhimento chamados de abrigos. Há abrigos para mulheres, idosos, crianças, adolescentes e pessoas em situação de rua, que

${ }^{7}$ O Cadastro Único, ou CadÚnico, é um instrumento de coleta de dados e informações que objetiva identificar todas as famílias de baixa renda para fins de inclusão em programas de assistência social e redistribuição de renda e realizado na maior parte dos Cras existentes. Mais informações a respeito serão abordadas em outros capítulos. 
funcionam como moradia provisória e oferecem proteção em situações como abandono e violência, isto é, em situações que exijam o afastamento do convívio com a família, como em casos de violência que crianças, adolescentes e mulheres sofrem em casa. Para idosos, os abrigos podem ser moradias permanentes.

De acordo com o Censo Suas de 2014, 256.858 trabalhadores, lotados nos Órgãos Gestores Municipal da Assistência Social e nas unidades públicas, operam o sistema de Assistência Social, sendo diversificada a forma do vínculo profissional conforme indica a tabela abaixo.

Tabela 1 - Trabalhadores da Assistência Social - tipo de vínculo profissional

\begin{tabular}{|c|c|c|c|c|}
\hline & $\begin{array}{c}\text { Ensino } \\
\text { Fundamental }\end{array}$ & Ensino Médio & $\begin{array}{c}\text { Ensino } \\
\text { Superior }\end{array}$ & Total \\
\hline Estatutários & 15.784 & 37.690 & 36.590 & 90.064 \\
\hline $\begin{array}{c}\text { Empregados Públicos } \\
\text { Celetistas }\end{array}$ & 4.401 & 13.624 & 10.244 & 28.269 \\
\hline $\begin{array}{c}\text { Somente } \\
\text { Comissionados }\end{array}$ & 4.548 & 20.842 & 18.060 & 43.450 \\
\hline Outros Vínculos & 15.295 & 53.357 & 26.423 & 95.075 \\
\hline Total & 40.028 & 125.513 & 91.317 & 256.858 \\
\hline
\end{tabular}

Fonte: Censo Suas 2014 (2015, p. 23) - Trabalhadores lotados na sede do Órgão Gestor Municipal da Assistência Social e nas unidades públicas, por tipo de vínculo.

A Normativa Operacional Básica de Recursos Humanos (NOB/RH), de dezembro de 2006, estabelece, dentre outras questões, a constituição das equipes técnicas de referência no Suas. Nessa normativa foram instituídas como profissões obrigatórias, a serem ingressas por meio de concurso público, assistentes sociais e psicólogos para os serviços de proteção social básica. Na proteção especial de média e alta complexidade, além desses profissionais citados acima, é obrigatória a contratação de advogados e de profissionais para desenvolvimento de atividades socioculturais, conforme apresentamos no quadro abaixo. 


\section{Quadro 1 - Profissões de nível superior no Suas}

\begin{tabular}{|c|c|}
\hline $\begin{array}{c}\text { Campos de Atuação no Suas - Nível } \\
\text { superior }\end{array}$ & Profissões \\
\hline Proteção social básica & Assistentes sociais e psicólogos \\
\hline $\begin{array}{c}\text { Proteção especial de média } \\
\text { complexidade }\end{array}$ & Assistentes sociais, psicólogos e advogados \\
\hline $\begin{array}{c}\text { Proteção especial de alta } \\
\text { complexidade }\end{array}$ & $\begin{array}{c}\text { Assistentes sociais, psicólogos e um profissional para } \\
\text { desenvolvimento de atividades socioculturais. }\end{array}$ \\
\hline
\end{tabular}

Fonte: Norma Operacional Básica de Recursos Humanos - NOB/RH/MDS. Elaborado pela a autora.

Com a Resolução CNAS n 17/2011, outras profissões conquistaram autorização para integrar as equipes de referência, caso seja avaliado pelo gestor a necessidade, tendo em vista o funcionamento e a qualidade do atendimento. Nesse sentido, podem compor as equipes de referência do Suas: antropólogos; economistas domésticos; pedagogos; sociólogos; terapeutas ocupacionais; musicoterapeutas; economistas; administradores e contadores. Abaixo, apresentamos tabela com dados que informam as especializações e o quantitativo de acordo com o Censo Suas de 2014.

Tabela 2 - Trabalhadores da Assistência Social - formação profissional

\begin{tabular}{|l|c|}
\hline & Total Brasil \\
\hline Assistente Social & 32.247 \\
\hline Psicólogo & 15.424 \\
\hline Pedagogo & 9.842 \\
\hline Advogado(a) & 3.102 \\
\hline Antropólogo(a) & 19 \\
\hline Sociólogo(a) & 325 \\
\hline Terapeuta Ocupacional & 382 \\
\hline Contador(a) & 1.063 \\
\hline Administrador(a) & 1.911 \\
\hline Economista & 197 \\
\hline Economista Doméstico & 45 \\
\hline Estatístico & 17 \\
\hline Musicoterapeuta & 111 \\
\hline Total & 64.685 \\
\hline
\end{tabular}

Fonte: Censo Suas 2014 (2015, p. 23). Total de trabalhadores de nível superior, por área de formação. 
Em 2012, o governo federal criou o Programa CapacitaSUAS nos estados, em parceria com as universidades e também na modalidade a distância, que é voltado para a formação dos trabalhadores, gestores e conselheiros da Assistência Social. Até 2014, foram ofertadas 112 mil vagas e foi realizado o investimento de 90 milhões de reais, conforme dados informados na plataforma "Dialoga Brasil".

Todo esse reordenamento institucional da Assistência Social, construído na última década, traz a marca do controle social, visto que todas as resoluções e normativas que envolvem o Suas têm a chancela do Conselho Nacional de Assistência Social (CNAS) e decorrem das deliberações das conferências municipais, estaduais e nacionais. No entanto, concomitante a essa atmosfera de avanços dos serviços socioassistenciais e da participação popular, nos dias 18 e 19 de maio de $2013,{ }^{8}$ cerca de 1 milhão de beneficiários do Programa Bolsa Família ganharam as ruas, em 13 estados, gerando muito tumulto, uma vez que foram informados que o programa iria acabar ou que o governo liberaria um adicional em comemoração ao Dias das Mães.

A pedido da presidente Dilma Rousseff, a Polícia Federal investigou o ocorrido e identificou que o boato não tinha relação com situação que se configurasse como crime, tal como as autoridades pensaram inicialmente. Percebeu-se que as informações, em tempos da muita midiatização, ganharam tempo e territorialidade, otimizando o boca a boca, ${ }^{9}$ principal recurso de comunicação utilizado pelo público atendido pela política de Assistência Social. Ou seja, a utilização de novas tecnologias pelos beneficiários, a exemplo das mensagens rápidas por celular (SMS), reforçou a estratégia de resistência destes, gerando impactos e pauta na grande mídia.

Em meio à implantação do Suas, o fato advertiu para a inexistência de mecanismos comunicacionais próprios e ágeis entre o governo e os beneficiários do maior programa de transferência de renda do mundo, uma vez que o Estado teve de se valer e contar de imediato com o apoio da mídia comercial para esclarecer que as informações em questão se tratavam de um boato sem fundamento.

Assim, considerando a relação entre o Programa Bolsa Família e a Assistência Social, tornou-se oportuno questionar como a Comunicação Pública tem sido realizada

\footnotetext{
${ }^{8}$ Esse fato será mais aprofundado no capítulo I.

${ }^{9}$ Esse assunto foi desenvolvido pela autora à época do mestrado, por meio de pesquisa junto a usuários com trajetória de rua que eram atendidos pela política de assistência social da prefeitura de Belo Horizonte (MG). O objetivo da pesquisa junto a esse público era conhecer como se informavam a fim de acessar essa a política de atendimento. A dissertação de mestrado recebeu o titulo Novos desafios para o Serviço Social na era das comunicações e foi defendida em junho de 2005, na Universidade do Estado do Rio de Janeiro (UERJ).
} 
junto aos usuários dos centros de referência da Assistência Social, haja vista o lócus e a importância que esse equipamento tem nos territórios, sendo os beneficiários o público preferencial da proteção social básica. Importava ainda investigar os tipo de informações, as formas e estruturas de comunicação que estavam sendo assegurados aos usuários e qual a percepção deles próprios com o advento do Suas, uma vez que para Castro (2015, p. 26) esse novo modelo dá oportunidade a "novas práticas políticas que fortaleçam a cultura de direitos em detrimento da "cultura da dádiva", mediação clássica do Estado brasileiro e forte tradição na assistência social".

Com base nesse fato e em outras informações advindas da atuação profissional na área da Assistência Social ao longo de vinte anos, realizou-se uma pesquisa exploratória, em 2013, junto a representantes do Ministério do Desenvolvimento Social e Combate a Fome e a secretários municipais de Assistência Social que representavam o Colegiado de gestores municipais (Congemas) na Comissão de Intergestores Tripartite (CIT) da Assistência Social ${ }^{10}$ com o objetivo de apurar a respeito da existência de uma política de comunicação da Assistência Social para os usuários. A partir das informações coletadas e analisadas, constatou-se a inexistência de uma política de Comunicação Pública para os usuários em todas as esferas de governo, o que não significava ausência de processos comunicativos junto aos usuários. Daí a importância de ir a campo para conhecer as características, as práticas, as ações, os planos e as estratégias da comunicação desenvolvidas pelos centros de referência de Assistência Social no atendimento ao cidadão, o que ocorreu no período de março de 2014 a janeiro de 2015, em cinco munícipios de porte habitacional diferenciado, nas cinco regiões do país. $^{11}$

A pesquisa e análise sobre a Comunicação Pública junto aos usuários da Assistência Social se estruturou com base no método dialético, por ser a metodologia mais conveniente para o estudo da realidade social em função de sua abordagem se fundamentar na ontologia do ser social, sendo a historicidade o seu lócus. Essa abordagem possibilitou uma maior compreensão acerca da Assistência Social enquanto uma política social em construção, como também a percepção da singularidade da Comunicação Pública e sua inserção nos direitos humanos, portanto, necessária às

\footnotetext{
${ }^{10}$ A Comissão de Intergestores Tripartite (CIT) é um espaço de articulação entre os gestores federais, estaduais e municipais e se caracteriza por ser uma instância de negociação e pactuação quanto aos aspectos operacionais da gestão do sistema descentralizado e participativo da assistência social.

${ }^{11}$ Os critérios que incidiram sobre as escolhas dos municípios visitados serão aprofundados no capítulo sobre o percurso metodológico.
} 
políticas sociais. A perspectiva dialética possibilitou também a contribuição de categorias e conceitos de análises transversais à Assistência Social e a Comunicação Pública, tais como a democracia, a cidadania, a questão social, as políticas sociais, a cultura e o Estado liberal de democracia de massas, permitindo uma maior aproximação e conhecimento do objeto investigado.

A análise da Comunicação Pública na Assistência Social numa totalidade permeada de contradições e mediações permitiu alguns entendimentos que esta tese visa evidenciar ao longo dos cinco capítulos. Uma das evidências tem relação com a Comunicação de Governo que, ao não organizar e publicizar as informações sobre a política de Assistência Social, esvazia o debate público e, em consequência, não são criadas as condições para superação do mito fundador, identificado por Chauí (2000) como a manutenção de um vínculo interno do passado como origem, uma vez que o mito fundador não cessa de procurar novos meios para se exprimir, novas linguagens, novos valores e ideias, de forma que pareça se tratar de uma novidade, e não de uma repetição de si mesmo, a exemplo do autoritarismo no Estado e na sociedade; a cultura senhorial; o patrimonialismo; o clientelismo; a privatização do público; a tutela e o favor, tão presentes na condição dos usuários da Assistência Social. De acordo com Silva (2014), a condição subalterna atribuída à população atendida historicamente pela Assistência Social é também uma característica da própria política, sendo necessário que os trabalhadores e gestores também busquem sair desse lugar.

Outra evidência é que a Comunicação Pública não está incorporada às diretrizes, capacitações e execução da política de Assistência Social porque nem toda estrutura de Estado, com destaque para os municípios que possuem uma relação direta com os usuários, "aprenderam a se comportar de forma a trabalhar com a informação voltada para a cidadania” (Brandão, 2007 apud Matos, 2009b, p. 3) ou se interessam pela manutenção de relações pautadas no primado liberal e no clientelismo. Nesse sentido, afirma-se não haver hegemonia da concepção fundada na cultura dos direitos com participação dos usuários, uma vez que "a política de Assistência Social move-se em um espaço contraditório e, muitas vezes, assume a lógica instituída de clientelismo e de favores, reiterando essa realidade imposta” (Silva, 2014, p. 162).

Esta tese busca evidenciar que a ausência da comunicação com características de pública nos Cras negligencia o potencial do Suas, que, de acordo com Silva (2014), tem a atribuição de construir direitos para as classes subalternas e, consequentemente, para a democracia na sociedade brasileira, dado que levar os usuários a participar ativamente 
da vida política é também uma tarefa da política de Assistência Social. Assim, com vistas a desenvolver e apresentar um estudo sobre os processos comunicativos nos Cras, tendo como referência as principais características e funções clássicas do conceito de Comunicação Pública, organizamos esta investigação em cinco capítulos que abordam o percurso metodológico, os referenciais teóricos, os dados e a análise da pesquisa sobre as compatibilidades e contradições entre Comunicação Pública e Assistência Social.

Para tal, o capítulo 1 apresenta o objeto, a justificativa e a metodologia adotada pela pesquisa, assim como a análise dos dados, sendo subdividido nos seguintes subcapítulos: a construção do objeto e o referencial teórico metodológico da pesquisa onde serão apresentadas as técnicas utilizadas e o campo de pesquisa. O capítulo 2 visa aprofundar as categorias e conceitos de análise utilizados para a compreensão da Comunicação Pública entre técnicos e usuários na Assistência Social. O capítulo 3 tem por objetivo analisar a trajetória histórica da Assistência Social no Brasil, bem como apresentar a estrutura de funcionamento do Suas. O capítulo 4 trata da Comunicação Pública com vistas à compreensão histórica e o conhecimento de suas particularidades, tendo em vista suas contribuições, uma vez que a Comunicação Pública se encontra no campo dos direitos humanos e, por isso, requer uma unidade dialética entre a dimensão humana e a técnica da comunicação, conforme indicou Gomes (2007). O capítulo 5 tem por objetivo apresentar os dados coletados da pesquisa documental e de campo, analisando-os com base nos referenciais teóricos. Para tal, será subdivido em dois subcapítulos. O primeiro subcapítulo analisa o Cras enquanto o lócus de atendimento ao usuário, uma vez que a Comunicação Pública é compreendida como um todo, sendo, portanto, necessário analisar a estrutura e o padrão de atendimento assegurado. $\mathrm{O}$ segundo subcapítulo está dividido em três blocos e aborda sobre a comunicação nos Cras. Para isso, no primeiro bloco a análise se dá na perspectiva de se obter uma totalidade da comunicação na Assistência Social, considerando as relações internas e externas, tendo o olhar dos técnicos e conselheiro representante dos usuários no Conselho Municipal de Assistência Social como as principais referências. O segundo bloco analisa a comunicação na política com os usuários a partir das considerações dos técnicos, enquanto o terceiro bloco apura e analisa a percepção dos usuários sobre a Assistência Social e assuntos correlatos, bem como a relação destes com as novas tecnologias e as melhores formas de comunicação com eles. Por fim, as considerações finais apresentam reflexões e questões acerca das compatibilidades e contradições entre Comunicação Pública e Assistência Social na atualidade. 


\section{CAPÍTULO 1}

\section{O percurso metodológico da pesquisa}

Este capítulo apresenta o percurso metodológico da pesquisa realizada, desde a construção do objeto até os critérios de definição do campo de pesquisa. O primeiro subcapítulo trata sobre as bases históricas e investigativas que colaboraram para a construção do objeto, revelando sua importância no contexto da política de Assistência Social. O segundo subcapitulo aborda o método dialético como o referencial teórico metodológico da pesquisa e apresenta a metodologia empregada e articulada ao método, bem como os critérios de escolha e o campo de pesquisa.

\subsection{A Construção do Objeto}

Entre os dias 18 e 19 de maio de 2013, a informação sobre o fim do Programa Bolsa Família (PBF), assim como que o governo havia liberado um adicional em comemoração ao Dia das Mães, levou cerca um milhão de beneficiários ${ }^{12}$ do $\mathrm{PBF}$, em 13 estados $^{13}$ do país, a efetuaram saques nas agências da Caixa Econômica Federal (CEF) e em Casas Lotéricas, gerando muito tumulto. Diante do ocorrido, o governo brasileiro convocou uma coletiva junto à imprensa para esclarecer o mal-entendido e solicitou à Polícia Federal $(\mathrm{PF})$ que deflagrasse uma investigação, temendo que o acontecimento decorresse de alguma atitude, nas palavras da presidenta, ${ }^{14}$ "criminosa". As investigações realizadas pela PF apontaram que aproximadamente $40 \%$ das pessoas encontravam-se na data correta do cronograma de pagamento da bolsa, sendo que

após a liberação antecipada do pagamento, ${ }^{15}$ expressiva quantidade de beneficiários do programa passou a ir aos bancos para retirar o dinheiro. Por não comportar o volume de sacadores, as agências ficaram sem dinheiro, o que, segundo os investigadores, pode ter sido

\footnotetext{
${ }^{12} \mathrm{O}$ dado fornecido pela mídia em geral à época foi de 900 mil pessoas. Após a apuração da PF, a imprensa, e especificamente o jornal Correio do Povo, em matéria de 12 de julho de 2013, informou serem 920 mil pessoas. Disponível em:

<http://portallw.correiodopovo.com.br/Noticias/?Noticia=503024>. Acesso em: 16 jul. 2013.

${ }^{13}$ Os 13 estados foram: Pará, Piauí, Paraíba, Bahia, Pernambuco, Ceará, Maranhão, Alagoas, Sergipe, Rio Grande do Norte, Amazonas, Tocantins e regiões localizadas do Rio de Janeiro.

${ }^{14}$ A fala da presidente foi divulgada pelos principais meios de comunicação e pode ser verificada em jornais impressos e digitais, principalmente nos dias 19 e 20 de maio de 2013.

${ }^{15}$ A Caixa Econômica Federal alterou as datas de repasse do recurso para melhor organizar o controle do serviço. No entanto, esta alteração não foi comunicada ao presidente da instituição bancária, que, por sua vez, não comunicou ao Executivo. Estes dados podem ser verificados em matérias da Folha de S.Paulo em 4 de junho de 2013, com o título: Pagamento antecipado vira foco do inquérito sobre Bolsa Família e em 16 de julho de 2013, sob o titulo Caixa antecipou pagamento do Bolsa Família sem licença.
} 
o gatilho para o inicio do boato replicado depois por rádios comunitárias e na internet de forma viral. ${ }^{16}$

Entre as linhas de investigação da PF, foi analisado o uso de redes sociais para a propagação dos boatos. $\mathrm{O}$ cruzamento de dados permitiu identificar uma postagem, feita em uma rede social, feita pela filha de uma beneficiária da cidade de Cajazeiras (PB), informando sobre o saque antecipado de sua mãe. Essa foi a primeira menção na internet a respeito do assunto, não se tratando, no entanto, da origem dos boatos.

De acordo com a polícia, a internet e as redes sociais apenas reproduziram notícias veiculadas pela imprensa sobre os tumultos em agências bancárias, e não ficou configurada a utilização de rádios comunitárias, telemarketing ou empresa contratada para a disseminação da informação de cancelamento do programa, como se propagou em um primeiro momento. Apenas uma beneficiária no Rio de Janeiro noticiou ter recebido telefonema a respeito.

As informações mostraram o aumento anormal no volume de saques nas cidades de Ipu (CE) e Cajazeiras (PB), onde ocorreram os primeiros saques, já nas primeiras horas do sábado, no dia 18 de maio. Essas cidades também apresentaram, proporcionalmente, o maior número de saques dos benefícios no final de semana.

Finalizadas as investigações, a PF divulgou, em 12 de julho de 2013, que os boatos tiveram origem espontânea, não havendo como afirmar que apenas uma pessoa ou grupo tenha causado os boatos envolvendo o Programa Bolsa Família. Concluiu-se, assim, pela "inexistência de elementos que possam configurar crime ou contravenção penal", conforme nota divulgada pela $\mathrm{PF} .^{17}$

Essa situação evidenciou que o tradicional boca a boca, principal recurso de comunicação utilizado pelos usuários da política de Assistência Social, como apontou a dissertação de mestrado desta autora, ganhou localidades longínquas por meio da utilização de novas tecnologias. O uso da internet e das redes sociais e, embora não se tenha divulgado amplamente, a utilização de mensagens rápidas por meio de celular (SMS), já estão na realidade dessas pessoas, como apontou a própria investigação da PF.

Outra situação evidenciada nesse episódio diz respeito à ausência de uma comunicação direta e ágil do governo com os beneficiários do Programa Bolsa Família,

\footnotetext{
${ }^{16}$ Informação extraída de matéria do jornal Folha de S.Paulo, de 4 de junho de 2013. Disponível em: $<$ http://www1.folha.uol.com.br/fsp/poder/112273-pagamento-antecipado-vira-foco-de-inquerito-da-pfsobre-bolsa-familia.shtml>.

${ }^{17}$ Informação divulgada amplamente pela mídia, em 12 de julho de 2013.
} 
uma vez que este teve de se valer apenas do apoio da mídia comercial para esclarecer que as informações em questão se tratavam de um boato sem fundamento. Assim, considerando a relação entre o Programa Bolsa Família e a Assistência Social, foi oportuno questionar como a Comunicação Pública estava sendo realizada no âmbito do Suas junto aos usuários, dado que esses beneficiários são o público preferencial da Assistência Social, atendidos principalmente nos Centros de Referência de Assistência Social (Cras). Assim, com base nesse fato, realizou-se uma pesquisa exploratória, em julho de 2013, com representantes do Ministério do Desenvolvimento Social e Combate a Fome (MDS), sendo entrevistadas à época Adriana Moraes, assessora de comunicação, e Simone Albuquerque, diretora de Departamento de Gestão do Sistema Único de Assistência Social da Secretaria Nacional de Assistência Social. Foram entrevistados também secretários municipais de Assistência Social que representam o Colegiado de Gestores Municipais (Congemas) na Comissão de Intergestores Tripartite (CIT) da Assistência Social. Os objetivos das entrevistas eram: a) apurar sobre a percepção dos secretários municipais acerca da comunicação com os usuários da assistência social, uma vez que ocupavam espaços de representação no controle social na condição de gestores municipais; b) identificar como a comunicação junto aos usuários da Assistência Social ocorria em seus estados e municípios. Os gestores municipais entrevistados à época foram Valdiosmar Vieira, presidente do Congemas e Secretário de Tobias Barreto/SE, município de Pequeno Porte II; secretário Marcelo Mourão de Belo Horizonte/MG representando as metrópoles; e o secretário Cleber Geovane Silveira de São Gabriel/RS, município de médio porte.

As entrevistas trouxeram informações que confirmaram a ausência de uma política de comunicação com características pública para os usuários da assistência social, em que pese o investimento do governo na comunicação com os gestores e os conselheiros por meio do site do MDS visitado à época, que contava com ações pontuais e com tentativas de criação de estratégias comunicacionais para os usuários, como indicou a diretora de gestão do Suas/MDS no decorrer da entrevista.

De acordo com Simone Albuquerque, diretora de gestão do Suas/MDS a comunicação com os usuários, do ponto de vista da gestão nacional, ainda é bastante tradicional, em que pese as orientações nas normativas por uma comunicação orientada a uma formação cidadã. Segundo a diretora, a comunicação institucional em geral diz pouco e não consegue passar que a assistência social é um direito porque existe uma 
grande dificuldade dos profissionais da área de comunicação em prestar assessoria à área da assistência social, conforme entrevista abaixo.

Eles têm uma forma própria de entender esta política. Para exemplificar, é comum que os técnicos de comunicação filmem o menino comendo ou tomando banho. Criam o personagem, mas não o sujeito de direitos. Algumas tentativas foram realizadas no âmbito federal, a exemplo da disponibilidade de contratação de profissionais para pensarem estratégias comunicacionais para os usuários, mas as propostas que apareceram foram avaliadas como inadequadas para serem enviadas para o país inteiro.

Entre os gestores entrevistados houve um consenso de que a comunicação da política está refém dos profissionais da ponta de atendimento. De acordo com Adriana Moraes, assessora de comunicação do MDS, “a comunicação com os usuários só pode acontecer com o milagre da multiplicação dos pães” em que pese os investimentos na área ${ }^{18}$. No entanto, compreendem que os técnicos (da ponta) também têm uma desconfiança grande, como se comunicar fosse também expor o trabalho que é feito com o usuário. Alguns gestores, a exemplo do secretário municipal de Belo Horizonte, entendem que o técnico que atua na política tem muita resistência a uma comunicação mais ampla, como se esta fosse dar visibilidade a algo que não deveria ser exposto, por se tratar de assuntos complexos, expondo, às vezes, sua incapacidade de sintetizar expressões da questão social. Há um receio coletivo dos reducionismos tão comuns

\footnotetext{
${ }^{18}$ Em entrevista a assessora de comunicação à época, Adriana Moraes informou que por ser o Ministério do Desenvolvimento Social um órgão recente boa parte da comunicação é terceirizada, sendo atribuição da assessoria o jornalismo, a publicidade, o cerimonial e produção de eventos. Antes os jornalistas ficavam distribuídos nos setores da instituição, havendo um profissional por área a exemplo do Programa Bolsa Família, Assistência Social, dentre outros. Neste caso havia um concentração e centralização de conhecimentos e informação. Caso aquele profissional saísse, saia com ele todo um acúmulo. Por meio da gestão do assessor de comunicação anterior a ela os jornalistas migraram para a assessoria. A ideia é que a equipe tenha uma visão mais geral e não tão fragmentada, em que pese à proximidade dos profissionais com algum tema em especial. No período da entrevista todos estavam concentrados na redação, sendo 30 jornalistas na parte de jornalismo/redação para dar conta dos sites e redes sociais, em turnos de trabalho de cinco mais duas horas. Buscou-se corrigir alguns problemas em decorrência das jornadas de trabalho, uma vez que algumas noticias eram iniciadas e finalizadas no dia seguinte. De acordo com a assessora há profissionais que trabalham o dia todo, que coordenam a equipe, tendo assim um horário diferenciado. Nessa entrevista a assessora apontou dúvidas em relação a este modelo de gestão da assessoria quanto à necessidade de em alguns setores haver um âncora/jornalista articulado a assessoria. Quanto à publicidade elas são determinadas pela SECOM (secretaria de comunicação vinculada à presidência da república), sendo a verba para publicidade do MDS muito pequena e só podendo ser executada com informações de utilidade pública.
} 
feitos à área pela mídia, que, na maioria das vezes, expressa uma visão muito preconceituosa dos usuários da assistência social, passando a ideia da dependência e se sustentando na máxima de "não dar a vara, mas ensinar o homem a pescar".

Segundo a assessora de comunicação do MDS, Adriana Moraes, tem-se feito um esforço para enfrentar as distorções de informação junto à mídia. Ela considera que o papel da mídia é mesmo de vigília, de atenção, de exigir, de cobrança, mas o que incomoda é se limitar apenas a isso, a exemplo do Programa Bolsa Família, que completou 10 anos e atualmente custa $0,45 \%$ do PIB nacional para atender um em cada quatro brasileiros. Um feito que nenhum governo fez, mas o que vira manchete são as fraudes insignificantes em comparação com a totalidade do programa. Ela afirma: "tudo bem que é o Leblon que lê isso, mas eu nunca vou conseguir falar para o Leblon que as fraudes são mínimas em relação à totalidade e aos impactos sociais?” Fica a frustração de ver que a imprensa não noticia o que está acontecendo e "termina desempenhando o papel de um partido político sem o ônus deste". Ainda, sobre os limites de uma comunicação dependente dos profissionais da ponta, Adriana Moraes questionou os assistentes sociais (maior contingente de técnicos do sistema), uma vez que, na relação institucional, a linguagem utilizada é complicada, cheia de conceitos densos, sendo um desafio para a assessoria traduzir o conteúdo para as pessoas. Considera que é necessário descomplicar, haver um aprendizado para ser mais direto e que talvez esse problema não aconteça em relação à comunicação direta com os usuários, isto é, é possível que a complicação esteja de lá para cá (do técnico para o gestor e assessoria de comunicação). "Afinal, o serviço acontece. Parece que funciona".

$\mathrm{Na}$ entrevista com Simone Albuquerque, diretora à época do Departamento de Gestão do Sistema Único de Assistência Social da Secretaria Nacional de Assistência Social do MDS, obteve-se a informação sobre a existência da ouvidoria do MDS, criada a partir da Lei de Acesso à Informação (Lai), utilizada com destaque, paradoxalmente, pelos moradores de rua, bem como uma página na rede social Facebook e o próprio site do MDS, embora este seja direcionado principalmente para gestores e conselheiros e, de acordo com a assessoria de comunicação do MDS, contava com problemas de ordem técnica, comprometendo a agilidade das informações.

Num processo de avaliação sobre a implantação do Suas, a diretora de gestão do Suas/MDS considerou que a primeira etapa tratou muito das normativas de regulação e funcionamento, das normas para a área de recursos humanos e do desenho do financiamento. Na segunda etapa, cuidou-se da construção da rede estatal. Na chamada 
terceira etapa, ou seja, a partir daquele momento, pretendiam qualificar a prestação dos serviços. Ou seja: i) liberação de recursos financeiros para contratação de recursos humanos concursados nos municípios; ii) adoção de um Plano de Carreira para o Suas; iii) ajuste da estrutura física à necessidade do território e ao atendimento das famílias; iv) ajuste da estrutura material (computador, telefone, dentre outros); v) organização de um sistema de informação, à disposição dos profissionais, que facilite os encaminhamentos dos assistentes sociais, tais como prontuários, acordos e protocolo intersetorial - para saber aonde encaminhar o usuário no território e na região.

À época da entrevista, Simone Albuquerque informou que o Conselho Nacional de Assistência Social (CNAS) deliberou pelo investimento na educação continuada e permanente dos trabalhadores do Suas, sendo constituída uma rede nacional de 101 universidades para a oferta desse serviço. O Programa Nacional de Capacitação (atualmente Programa CapacitaSuas) possuía naquele momento 30 milhões de reais, com investimento maior do MDS, mas também dos estados e do Distrito Federal. A indicação era para a realização de cursos de especialização e atualização, com uma oferta variada entre capacitações de 20 horas até o nível de mestrado. No entanto, ressaltou que a questão do direito à comunicação não foi destacado. Na entrevista, ela manifestou o entendimento de ser necessário qualificar a comunicação oral, mas também investir na criação de outras formas de comunicação. Informou também que foi realizado um acordo com a Fiocruz/UnB (área do direito sanitário) para discutir o direito à assistência social. Além disso, foi realizado um concurso de artigos sobre o direito de assistência social para que, no ano de 2014, fosse realizado um seminário sobre o tema. No entanto, "em hora nenhuma, a questão do direito à comunicação entrou em alguma linha temática".

Nas entrevistas, considerou-se oportuno aprofundar sobre uma atividade desenvolvida nos Cras, denominada de Busca Ativa, ${ }^{19}$ que tem por objetivo identificar, nos territórios, pessoas com potencial de inclusão na política de assistência social. Para tal é necessário a mobilização e a utilização de estratégias e instrumentos de comunicação. Segundo a diretora de gestão do Suas, é comum a realização de eventos conjuntos entre o MDS e os governos estaduais. Afirma que, por meio dessa ação conjunta, consegue-se mobilizar a imprensa. Outra estratégia adotada, quando oportuna, tem sido a de envolver a Marinha do Brasil. São 74 lanchas, com 17 pessoas, que vão

\footnotetext{
${ }^{19}$ Cf. Orientações Técnicas da Proteção Social Básica do Sistema Único de Assistência Social - SUAS: Centro de Referência de Assistência Social - Cras. Publicado em 2009 e reimpresso em 2012.
} 
para as comunidades em situação de isolamento. Nessa operação, além do atendimento, também é realizado um trabalho educativo. "O que o ministério faz mesmo é disponibilizar recursos para que os municípios apliquem, estando liberada a forma de aplicação do recurso", afirma a gestora.

Simone Albuquerque, diretora à época do Departamento de Gestão do Sistema Único de Assistência Social da Secretaria Nacional de Assistência Social do MDS, informou ainda que, apesar de experiências bem sucedidas como a Campanha de Erradicação do Trabalho Infantil, a Campanha Contra o Abuso e Exploração Contra a Criança e o Adolescente e o Dia da Mulher, ${ }^{20}$ ainda não há um acúmulo em relação à comunicação com o usuário da assistência social a ponto de estruturar uma política nacional de comunicação com vistas aos objetivos propostos nas normativas e deliberações das conferências. Um fator que interfere nessa construção diz respeito à relação entre os entes federados, uma vez que os municípios e estados gozam de autonomia administrativa na aplicação dos recursos financeiros proposto pelo governo federal, o que propicia e termina por determinar a forma e o teor da comunicação com o usuário. Ou seja, variáveis como a concepção político-ideológica dos governantes e gestores sobre a questão da pobreza e a assistência social enquanto uma política reparadora, ou ainda sobre a escolha do perfil e a forma de contratação dos profissionais, ou mesmo sobre as condições do imóvel e insumos para funcionamento do equipamento público, são determinantes e interferem na Comunicação Pública na assistência social.

A partir das informações coletadas e analisadas, confirmou-se que a inexistência de uma comunicação ágil e direta do governo com os beneficiários do Programa Bolsa Família, especialmente na época do episódio conhecido como "Boato do fim do Bolsa Família”, derivou da ausência de uma política de Comunicação Pública para os usuários da assistência social, em todas as esferas de governo. No entanto, considerou-se que a ausência de uma política de comunicação não significava a ausência de processos comunicativos junto aos usuários na ponta do atendimento. Daí a importância de ir a campo para investigar: quais tipos de informações estavam sendo priorizadas para os

\footnotetext{
${ }^{20}$ De acordo com a diretora da gestão do Suas/MDS, esses três temas se repetem há vários anos em todo o país, envolvendo órgãos de outras políticas, bem como a ponta de atendimento do Suas, que também articula a rede e desenvolve ações nos territórios. O material é produzido (cartaz e folder) junto com as secretarias temáticas. Não há nenhuma produção especifica para os profissionais trabalharem com os usuários, mas liberação de recursos para que os municípios invistam. Outra experiência é o envio de cartas do MDS para os usuários do PBF e PBC (Programa de Benefícios Continuados), mas não há um monitoramento. "Pega-se o endereço e envia, não tem nada direcionado".
} 
usuários? Como o direito à comunicação era percebido pelos técnicos e pelos usuários no Cras? Como os técnicos percebiam e se organizavam para realizarem o trabalho educativo proposto pelas normativas do Suas? Quais eram as estruturas e os recursos disponíveis nos municípios? Como os usuários compreendiam os serviços oferecidos? Ainda: diante da perspectiva da "multiplicação dos pães", como os profissionais nos Cras se percebiam nessa função?

Além dessas questões, a investigação sobre a comunicação efetivada na prática entre a Assistência Social e os usuários deveria avaliar em que medida esse processo se aproximava dos preceitos básicos da Comunicação Pública, que, pela natureza da democracia, deveriam ser inerentes aos processos comunicativos entre o Estado, governo e sociedade, em especial na Assistência Social, tendo em vista a clássica mediação do Estado brasileiro e forte tradição na área, denominado por Castro (2015) como cultura da dádiva. Chauí (2000) entende tal cultura como o mito fundador, aquele que não cessa de procurar novos meios - novas linguagens, novos valores e ideias para se exprimir, mas que objetiva a manutenção de um vínculo interno do passado como origem. Silva (2014), por sua vez, destaca que a condição subalterna atribuída à população atendida historicamente pela Assistência Social é também uma característica da própria política, sendo necessário que os trabalhadores e gestores também saiam desse lugar.

A pesquisa de campo sobre a Comunicação Pública junto aos usuários dos Centros de Assistência Social requereu uma compreensão dialética, capaz de perceber as contradições e mediações existentes, haja vista que já se observava, a partir das entrevistas da pesquisa exploratória, ambiguidades decorrentes da disputa entre a concepção do direito social com protagonismo do usuário e a concepção pautada na manutenção da subalternidade.

\section{$1.2 \mathrm{O}$ referencial teórico metodológico da pesquisa}

O método dialético foi escolhido como o referencial teórico-metodológico para o desenvolvimento e para a análise da pesquisa sobre a comunicação junto aos usuários da política de assistência social nos Cras por sê-lo mais conveniente ao estudo da realidade social, em função de seu pressuposto ontológico - a historicidade - e da perspectiva da totalidade, que, por sua vez, é central para se compreender a dinâmica contraditória do real. Partiu-se então da concepção de que a realidade é um construto humano histórico, 
não havendo nenhuma dimensão transcendente à história a determinar os processos sociais, sendo "os homens os únicos e exclusivos demiurgos do seu destino, não havendo aqui nenhum limite imposto a eles senão as próprias relações sociais construídas pela humanidade" (Lessa, 2006, p. 92).

De acordo com Flick (2009), o objeto em estudo é o fator determinante para a escolha de um método, e não o contrário. Os objetos devem ser pensados em uma totalidade, dentro de seus contextos cotidianos, afastando-se a possibilidade de reducionismos. $\mathrm{O}$ autor sugere o cuidado, no caso das ciências sociais, para que os campos de estudos não sejam advindos de situações artificiais, e sim definidos a partir das práticas e das interações entre os sujeitos na vida cotidiana. Assim, envolve um conjunto de construtos que articulam abstrações, generalizações, formalizações e idealizações. Organiza, por assim dizer, as experiências que primeiramente permitem a cognição do mundo além do sujeito, sendo estruturadas e compreendidas por meio dos conceitos e dos contextos construídos por ele. Portanto, o conhecimento é construído em processo de mudança social, pois, de acordo com Minayo (2003), o objeto das ciências sociais é histórico, uma vez que o presente é marcado pelo passado e projetado para o futuro, num embate permanente entre o que está dado e o que está sendo estruturado. Nesse sentido, de acordo com alguns autores - Minayo (2003), Flick (2009), Peruzzo (2012) -, é preciso ressaltar que nas ciências sociais existe uma identidade entre sujeito e objeto em que o observador é da mesma natureza que o objeto, sendo o observador parte de sua observação. Outro aspecto distintivo dessas ciências, apontado por Minayo (2003, p. 14), é o "fato de ela ser em si intrínseca e extrinsecamente ideológica. Ninguém hoje ousa negar que toda ciência é comprometida". Trata-se de uma condição da pesquisa que deve ser incorporada como critério de realidade e busca de objetivação. $\mathrm{Na}$ investigação social, a relação entre o pesquisador e seu campo de estudo se estabelece definitivamente. Assim, importa a afirmativa de que o objeto das ciências sociais é essencialmente qualitativo, por ser a realidade social o próprio dinamismo individual e coletivo.

A dialética compreende a realidade social numa totalidade composta por essência e aparência, ambas resultantes do processo histórico, permeado, portanto, por contradições e mediações. Kosik (1995) afirma que, para apreender a essência, precisase do fenômeno e de sua manifestação, dado que a aparência fenomênica e imediatamente dada pela realidade é um ponto de partida, afinal, a realidade é um todo e expressa a unidade entre aparência e essência, apesar de não haver coincidência direta 
entre as mesmas. Para se desvendar a essência de um fenômeno é necessário propor a decomposição do todo em aproximações sucessivas e permanentes, como um ir e vir do conhecimento em relação ao fenômeno analisado, realizar um detóur (Kosik, 1995), pois a aproximação com a verdade depende do conhecimento sobre o fenômeno, que advém da construção histórica influenciada por múltiplas relações sociais e com a própria construção do conhecimento. A dialética requer o entendimento de que nada pode ser percebido de modo isolado, sendo que totalidade não significa uma soma funcional de partes integradas ou a separação das condições objetivas e subjetivas, que, embora sejam distintas e não necessariamente antitéticas, estão no mesmo patamar. A unidade é, portanto, configurada por meio da práxis, isto é, "uma atividade mediadora que faz com que da conjunção desses dois momentos se origine toda a realidade social" (Tonet, 2013, p. 78).

A totalidade pressupõe o entendimento de que toda realidade social é um conjunto articulado de partes, sendo que cada uma delas é em si mesma uma totalidade de maior ou menor complexidade. As partes que constituem cada um desses conjuntos se determinam reciprocamente e sua natureza é resultado de uma processualidade. De acordo com Tonet (2013, p. 96), "na totalidade há uma relação dialética entre o todo e as partes, porém, o todo é determinante. Esse conjunto é permeado por contradições e mediações que resultam no dinamismo próprio de todos os fenômenos sociais." Demo (1995, p. 91) aponta que "a alma da dialética é o conceito de antítese, uma vez que toda realidade social gera por dinâmica interna própria, seu contrário ou as condições objetivas e subjetivas para a sua superação". Ou seja, a antítese decorre da dinâmica do conflito social existente a partir de uma síntese que é uma tese e, assim, produz uma nova síntese decorrente do processo interno instaurado, constituindo, desse modo, o esquema básico que consagra a trilogia: tese, antítese, síntese, que, para Demo (1995), é, na verdade, uma duologia, dado que a síntese é apenas a próxima tese. É preciso, no entanto, compreender que a antítese não é uma fase: ela representa a negação e a superação de um determinado fenômeno social, ou, como apontou Hegel (1992), representa a superação (Alfheben) e elevação a um novo patamar. O método dialético tem uma natureza dinâmica e não pode ser concebido como um conjunto estanque e fixo de regras, fórmulas e normas aplicáveis na realidade, pois, inclusive do ponto de vista dialético, "não existe nada eterno, nada fixo, nada absoluto. (...) Tudo o que existe na vida humana e social está em perpétua transformação, tudo é perecível, tudo está sujeito ao fluxo da história" (Lowy, 2010, p. 14). 
A unidade do diverso é uma marca da dialética, uma vez que a realidade é concreta, uma síntese de muitas determinações. As determinações são traços pertinentes aos elementos constitutivos da realidade e estão postas na imediaticidade do real, mostrando-se como singularidade. Dessa forma, o conhecimento do concreto deve ser operado envolvendo universalidade, singularidade e particularidade, pois o imediato, ou o aparente, é sempre caótico, em função da heterogeneidade e da variedade dos dados imediatos, que não permitem apreender os vários elementos que compõem o objeto, suas articulações e conexões, bem como a dinâmica de todo o processo. Para Frigotto (2006, p.75), “a dialética, para ser materialista-histórica, enquanto uma postura, concepção de mundo e método de apreensão radical da realidade, ou seja, que vai à raiz precisa dar conta da totalidade, do específico, do singular e do particular". Para a dialética, a realidade é sempre mais rica do que o conhecimento que se tem dela, haja vista que tudo o que existe está em processo. O conhecimento, portanto, é sempre um processo aproximativo. Na dialética, a teoria significa conhecimento do objeto em sua estrutura e em sua dinâmica, na sua existência real e efetiva, independentemente das aspirações e representações do pesquisador. Significa ir além da aparência fenomênica, imediata e empírica, por onde necessariamente se inicia o conhecimento e, por meio de procedimentos analíticos, operar a síntese, reproduzindo no plano do ideal o movimento real do objeto. Isso significa que na relação sujeito e objeto no processo do conhecimento teórico dialético não há uma relação de externalidade, como se dá nas ciências naturais, não havendo, portanto, neutralidade por parte do pesquisador. Assim, o instrumento apropriado para realizar a crítica dos dados imediatos e sair da aparência com vistas à essência é a abstração, uma vez que a realidade social não pode ser submetida aos mesmos processos experimentais, sendo as técnicas e procedimentos similares apenas meios auxiliares como foi a observação e entrevistas nos Cras.

Importa compreender que a abstração não se reduz a uma operação lógica, tendo em vista o seu caráter ontológico. É algo que se realiza na realidade. No processo de abstração devem ser estabelecidas as diferenças, as semelhanças e as articulações que ocorrem no interior do objeto de estudo. De acordo com Tonet (2013, p. 120), “o processo lógico de abstração é a busca por traduzir no plano ideal o que acontece no plano da realidade". Na perspectiva ontológica, a abstração não pode ter um caráter subjetivo, e sim tem de provir do próprio objeto. É preciso ter em mente que o conhecimento é um processo em que estão presentes, embora em níveis diferentes, a universalidade, particularidade e singularidade. Dessa forma, ao abstrair ou separar 
algum elemento particular ou singular, este não perderá o vínculo com a universalidade. Somente a articulação entre esses três elementos ao longo do processo concreto permitirá verificar se a abstração que está sendo realizada é verdadeira ou não.

O método dialético consiste, portanto, na capacidade humana de ultrapassar, por meio da razão, o nível dos fatos imediatos, captando a realidade de forma aproximada e sucessiva em suas conexões, determinações e nexos constitutivos. De acordo com Guiraldelli $^{21}$ (2015), o processo investigativo que recorre à ontologia histórico-dialética recusa o empirismo ingênuo enquanto fato dado, imediato, acrítico, divinizado, fetichizado e desprovido de mediações. É no cotidiano que o fenomênico se manifesta e se apresenta como singularidade. Portanto, a singularidade tem relação com os fatos, com o imediato, com o aparente, com a coisa. ${ }^{22}$ Para compreendê-la e sair do fenomênico para a essência, do abstrato ao concreto, é preciso relacioná-la, buscar os nexos constitutivos na universalidade, na qual se encontram as leis tendenciais históricas, a legalidade social, isto é, o histórico sistemático e as estruturas. Construídas as conexões, torna-se necessário conectá-las às determinações que se encontram na particularidade da realidade em estudo. Na particularidade se percebe as contradições e as mediações que influem e determinam o fenômeno em estudo. É a partir da particularidade que se inicia o processo de síntese e se desvenda o aparente, confirmando que "o conhecimento concreto do objeto é o conhecimento de múltiplas determinações" (Netto, 2009, p. 685).

Em nosso caso, a singularidade dessa pesquisa se encontra na constatação inicial da ausência de uma política de comunicação para os usuários da Assistência Social, revelada a partir do boato sobre o "fim do Programa Bolsa Família" e se constitui com a pesquisa exploratória. Aparentemente, por exemplo, poder-se-ia, a princípio, ter-se tomado a ausência da política de comunicação enquanto uma ausência de processos comunicativos. No entanto, ao abstrair-se e perceber-se os usuários na universalidade do Sistema Único de Assistência Social (Suas), considerou-se as possibilidades de um contato direto e, consequentemente, de uma comunicação. Desse modo, em nossa pesquisa identificamos o Cras por ser uma unidade pública estatal e, também, a principal porta de acesso dos usuários à política de Assistência Social. A partir de tal

\footnotetext{
${ }^{21}$ Anotações realizadas na palestra do professor Reginaldo Guiraldelli, no encontro do Grupo de Estudos e Pesquisas sobre Trabalho, Sociabilidade e Serviço Social - TRASSO, em 12 mar. 2015.

${ }^{22}$ COISA - Tudo aquilo que possui uma existência individual e concreta. Sinônimo de objeto, portanto realidade objetiva, isto é, independente da representação. Nesse sentido, a coisa se opõe à ideia (Japiassú \& Marcondes, 1996, apud Malina, 2002).
} 
identificação, pôde-se investigar a particularidade sobre a comunicação efetivada na prática junto aos usuários, desvendando-se a essência sobre essa questão. A particularidade que se revelou nos Cras em relação à Comunicação Pública com o usuário apontou para algumas questões, tais como: o padrão de atendimento estabelecido nos Cras; o fluxo, organização e os tipos de informação; a concepção e as ações da equipe técnica em relação ao direito à comunicação do usuário; a compreensão dos usuários sobre a política de Assistência Social; e questões relacionadas à comunicação interna e externa na Assistência Social.

Essas informações articuladas à totalidade da Assistência Social e da Comunicação Pública em suas dimensões históricas, todas elas vinculadas a outras totalidades como a dinâmica política, econômica e social do país e às categorias ontológicas e reflexivas, aprofundadas no capítulo 2, foram decisivas para retratar-se o movimento do objeto e chegar-se à essência sem, contudo, obter uma compreensão estagnada, em função da dinamicidade da realidade, da comunicação junto aos usuários da Assistência Social, gerando o conteúdo desta tese.

Assim, nossa metodologia adotou técnicas e instrumentos necessários à apreensão da matéria na perspectiva da análise dialética, os quais estão apresentados a seguir.

\subsubsection{Técnicas de pesquisa}

A metodologia deve ser compreendida como o conjunto de procedimentos, técnicas, meios e instrumentos utilizados nas sucessivas aproximações do objeto e devem ter relação com o método de análise. Constituem o caminho do pensamento e a prática exercida na abordagem do real, de forma que estejam incluídas as concepções teóricas de abordagem, o conjunto de técnicas que possibilitem a construção da realidade e o "sopro divino do potencial criativo do investigador" (Minayo, 2003, p. 16), uma vez que a escolha do objeto, do método e dos procedimentos metodológicos não é uma atitude neutra. Como afirma Netto (2011, p. 25-26),

[...] os instrumentos e também as técnicas de pesquisa são os mais variados, desde a análise documental até as formas mais diversas de observação, recolha de dados, quantificação etc. Esses instrumentos e técnicas são meios de que se vale o pesquisador para "apoderar-se da matéria", mas não devem ser identificados com o método: instrumentos e técnicas similares podem servir (e de fato servem), em escala variada, a concepções metodológicas diferentes. 
A escolha pelo método dialético demandou, tendo em vista o seu caráter abrangente e histórico, a pesquisa bibliográfica e documental, que se realizou em todo o processo que envolveu a tese, a fim de que os nexos fossem construídos tanto no que diz respeito à Assistência Social quanto à Comunicação Pública, bem como estes entre si. $\mathrm{O}$ processo investigativo com base no método dialético também possibilitou o contato direto com os sujeitos pesquisados e a observação no período da visita, propiciando uma pesquisa qualitativa. O contato com os sujeitos se deu por meio de entrevista estruturada, utilizando questionários específicos para usuários, representantes dos usuários no CMAS, técnicos e gestores (Anexos 1, 2, 3 e 4) como instrumento de coleta de informações e garantindo que a mesma pergunta fosse feita da mesma forma a todos os técnicos e usuários que foram entrevistados. De acordo com Gil (1999, p. 121), a entrevista estruturada "desenvolve-se a partir de uma relação fixa de perguntas, cuja ordem e redação permanece invariável para todos os entrevistados, que geralmente são em grande número".

As entrevistas realizadas foram diferenciadas, mas com pontos comuns, para os técnicos, usuários e conselheiros usuários integrantes do Conselho municipal de Assistência Social. Para os técnicos, as questões se orientaram no sentido de verificar a percepção sobre o direito à comunicação dos usuários, sobre o tipo de informação priorizada, as formas e a estrutura que possuem e produzem para a realização da comunicação e do trabalho educativo, dentre outros. O roteiro de entrevistas para os usuários abordou: a) a percepção deles próprios em relação às possibilidades de atendimento de suas necessidades sociais na Assistência Social; b) como avaliam a resolutividade no atendimento; c) a relação com as tecnologias de comunicação e d) as melhores formas de comunicação individual e coletiva. Quanto ao roteiro para usuários integrantes do Conselho Municipal de Assistência Social, este se estruturou de forma a apurar o entendimento sobre Assistência Social como política pública e as melhores formas de se comunicar com o usuário, além da questão da relação entre o usuário e os meios e tecnologias de comunicação.

Importa esclarecer que, no projeto de pesquisa qualificado, a proposta era entrevistar individualmente os coordenadores dos Cras. No entanto, à exceção do Cras Menino Jesus em São Gabriel/RS, os demais coordenadores solicitaram que a entrevista fosse conjunta com a equipe técnica, o que foi acatado. Todos os usuários integrantes do Conselho Municipal de Assistência Social foram entrevistados individualmente. 
Em Belo Horizonte/MG e Santarém/PA, a estrutura institucional é bem hierarquizada, haja vista se tratar de uma metrópole e um município grande. Isso exigiu da pesquisa contatos e entrevistas com os gerentes de proteção social básica que coordenam e gerenciam todos os Cras no município. Em Belo Horizonte destaca-se ainda a Gerência de coordenação da política de Assistência Social que participa também da gestão sobre os Cras.

A observação se deu de forma sistemática e semiestruturada, uma vez que se escolheu previamente as categorias de observação sem se fechar à formação de novas categorias, como apontou Ferreira e outros (2012), repetindo-se a mesma orientação na observação em todos os Cras visitados. Realizou-se também registros em diário de campo e por meio de fotografias. As visitas nos Cras não podem se caracterizar como pesquisa etnográfica e nem como observação participante em decorrência da dinâmica no campo e o tempo aplicado, pois, de acordo com Flick (2009), em sua forma mais característica, a participação do etnógrafo na vida cotidiana das pessoas deve se dar por um período prolongado de tempo, a fim de que seja observado o que acontece, seja escutado o que é dito e seja questionado e coletado qualquer dado afim.

A pesquisa empírica foi realizada nos Cras de cinco municípios: Belo Horizonte/MG, Santarém/PA, São Gabriel/RS, Tobias Barreto/SE, Rubiataba/GO nas cinco regiões do país, sendo os critérios de escolha construídos a partir da Política Nacional de Assistência Social de 2004, conforme apresentação a seguir.

\subsubsection{Campo de pesquisa}

A escolha dos municípios foi feita a partir dos critérios estabelecidos pela Política Nacional de Assistência Social (PNAS/2004), que distingue os municípios pela dinâmica populacional, conforme o Quadro 2: 
Quadro 2

\section{Porte dos municípios}

\begin{tabular}{|c|c|c|}
\hline Porte do município & População & Número de municípios \\
\hline Municípios pequenos 1 & Até 20.000 habitantes & 4.018 \\
\hline Municípios pequenos 2 & Entre 20.001 e 50.000 habitantes & 964 \\
\hline Municípios médios & Entre 50.001 e 100.000 habitantes & 301 \\
\hline Municípios grandes & $\begin{array}{c}\text { Entre 100.001 e 900.000 } \\
\text { habitantes }\end{array}$ \\
\hline Metrópoles & Superior a 900.000 habitantes & 209 \\
\hline \multicolumn{2}{|c|}{ Fonte: MDS/CNAS (PNAS, 2004, p. 16) } \\
\hline
\end{tabular}

Para realização da pesquisa, compatibilizou-se o porte demográfico e a região do país de forma a assegurar que fosse visitado um município de cada porte em uma determinada região (Norte, Nordeste, Centro-Oeste, Sudeste e Sul). Assim, esperava-se assegurar, dentro das possibilidades e limites desta pesquisa em detrimento da dimensão continental do país, as particularidades decorrentes da estrutura organizacional e administrativo-financeira, bem como os aspectos culturais e de desenvolvimento local e regional. Outro critério adotado, mas não universalizado, foi a representação do município na diretoria do Congemas e nas instâncias de deliberação e pactuação da política, pela oportunidade de se fazer um paralelo entre as questões deliberadas e as executadas no respectivo munícipio. Dessa forma, elegeu-se e visitou-se os seguintes locais:

\section{Quadro 3}

\section{Municípios e regiões visitada}

\begin{tabular}{|c|c|c|}
\hline Porte & Município/Estado & Região \\
\hline Pequeno porte 1 & Rubiataba/Goiás & Centro-Oeste \\
& 18.915 hab. & Nordeste \\
\hline Pequeno porte 2 & Tobias Barreto/Sergipe & Sul \\
& 48.040 hab. & \\
\hline Municípios médios & São Gabriel/Rio Grande do & Sul \\
& 60.425 hab. & Norte \\
\hline Municípios grandes & Santarém/Pará & Sudeste \\
& 294.580 hab. & \\
\hline Metrópoles & Belo Horizonte/Minas & Gerais \\
& 2.375 .151 hab. & \\
\hline
\end{tabular}

Fonte: Censo IBGE 2010. Quadro elaborado pela autora.

\footnotetext{
23 A PNAS/2004 utilizou dados do IBGE de 2000 e o Atlas do Desenvolvimento Humano de 2002. Embora o número de municípios oficialmente divulgado pelo IBGE seja de 5.561, o Atlas do Desenvolvimento Humano trabalhou com um universo de 5.509 municípios por razões metodológicas.
} 
O município de Rubiataba não participava das instâncias democráticas da política à época, no entanto, foi escolhido por causa do porte - no estado de Goiás os municípios geralmente possuem grandes áreas territoriais e baixa densidade demográfica - e em função de um Cras itinerante que atende a aldeia indígena dos Tapuias, na Reserva do Carretão, além de o município possuir um Cras fixo no centro da cidade. Dessa forma, assegurou-se algumas particularidades, como a questão das grandes extensões fundiárias e a questão indígena como público da Assistência Social. O Cras de Rubiataba conta com um blog próprio, uma página na rede social Facebook e produz também um jornal e uma revista digital com o site da prefeitura.

O município de Tobias Barreto foi escolhido por sua participação política nas instâncias de decisão, por causa de seu porte e por estar na região do semiárido sergipano, na divisa com o estado da Bahia. Na fronteira, há um povoado, com cerca de 7.000 habitantes, vinculado administrativamente ao município baiano de Itapecuru, cuja sede está a 20 quilômetros do local. Em decorrência dessa localização, toda a demanda de assistência social do povoado ocorre em Tobias Barreto, uma vez que apenas uma ponte separa os municípios. Dessa forma, essa região, cuja condição climática é desafiadora, sendo a principal fonte de arrecadação o comércio varejista e a produção de artesanato, com destaque para os bordados em tecido, enfrenta também a contradição de algumas divisões geopolítico-administrativa imprimidas no país. O município dispõe de dois Cras, um voltado para o atendimento da população urbana e outro para a população rural, e em ambos funciona uma central de cadastramento do Programa Bolsa Família. A prefeitura, por sua vez, possui um site pouco alimentado.

O município de São Gabriel foi escolhido por causa de sua participação nas instâncias da política de Assistência Social, por seu porte e por ser uma cidade próxima da fronteira com outros países da América Latina. São Gabriel está localizada nos pampas gaúchos, na fronteira oeste do Rio Grande do Sul, às margens da BR-290, rota do Mercosul. Situada num corredor de importação e exportação, está a 320 quilômetros de Porto Alegre, a 290 quilômetros do Porto Internacional de Rio Grande, a 300 quilômetros de Uruguaiana/Argentina e a 170 quilômetros de Livramento/Uruguai. Além disso, é o $3^{\circ}$ maior município em extensão no estado, sendo que sua principal arrecadação advém do setor primário e terciário. Possui apenas um Cras, onde atuam 12 profissionais com formação de nível superior, sendo todos eles concursados. O Cras 
atende cerca de 8000 pessoas ao ano na proteção básica. No município, existem nove jornais, três rádios cidade, sendo duas AM e uma FM, além de blogs de opinião.

O município de Santarém, embora também à época não participasse das instâncias de discussão e deliberação da política no âmbito nacional, foi escolhido por seu porte e por estar situado numa região do baixo Amazonas, sendo um centro polarizador da região oeste do Pará, por oferecer melhor infraestrutura econômica e social (escolas, hospitais, universidades, estradas, portos, aeroporto, comunicações, indústria e comércio, etc.) e ter um setor de serviços mais desenvolvido. A área de abrangência dos Cras também é diferenciada em relação às de outras áreas do país tendo em vista a grande extensão territorial que ainda é separada por afluentes e pela confluência do rio Tapajós com o rio Amazonas. Santarém ocupa uma área urbana de aproximadamente 77 quilômetros quadrados. Isso lhe dá, de acordo com a Lei do Plano Diretor, Lei $\mathrm{n}^{\mathrm{o}} 18.051 / 2006$, uma zona urbana com cinco distritos, delimitando 48 bairros, e uma zona rural com estes oito distritos: distrito do Lago Grande do Curuai, distrito do Rio Arapiuns, distrito do Rio Tapajós, distrito do Rio Amazonas, distrito do Eixo Forte, distrito do Rio Mojui, distrito do Rio Moju e distrito do Rio Curuá-Una. De acordo com os dados do Programa Agentes Comunitários de Saúde 2009, da Secretaria Municipal de Saúde (Semsa), são 472 comunidades rurais distribuídas ao longo desses distritos, das quais 260 localizam-se nas regiões dos rios e várzeas e 212 estão na zona do planalto.

A cidade de Belo Horizonte foi escolhida por sua participação nas instâncias nacional de deliberação da política, por ser um município com cerca de 2,4 milhões de habitantes e ter uma relação história com a Assistência Social já que foi referência na implantação da Loas, entre as décadas de 1990 e de 2000, servindo de referência para a criação do Suas. É uma cidade que tem na prestação de serviços sua principal fonte de arrecadação. A política de assistência social é gerenciada pela Secretaria Municipal de Assistência Social e, em seu organograma no nível central para o gerenciamento dos CRAS, conta, além do gerenciamento local, com as seguintes gerências e setores: Gerência de Proteção Básica; Gerência de Coordenação da Política de Assistência Social; Gerência de Monitoramento e Avaliação e Assessoria de Comunicação e Mobilização Social. Atualmente, 33 Cras prestam serviços na capital mineira, que tem a projeção de ampliar, nos próximos anos, para mais 21, totalizando 54 centros. Os Cras estão inseridos nas nove regiões administrativas da cidade, sendo cada um deles referência para cinco mil famílias e atendendo, no mínimo, mil famílias por ano. 
Segundo o site da prefeitura, ${ }^{24}$ mais de 150 mil pessoas são atendidas nas nove regionais de Belo Horizonte.

As visitas aos Cras se basearam nos seguintes critérios: municípios com até dois Cras foram visitados na sua totalidade, uma vez que se trata de públicos diferentes, como é o caso de Tobias Barreto, que, apesar de ser de pequeno porte 2, possui uma unidade para atender a população urbana e outra para atender a população rural. No caso dos municípios com mais de dois Cras, como é o caso de Santarém/PA e Belo Horizonte/MG, os critérios foram construídos com a equipe de coordenação da proteção básica, por envolverem dimensões da realidade local desconhecidos a priori, tais como: a forma de organização, as condições de acesso e de segurança, a disponibilidade da equipe, dentre outras.

A título de curiosidade, uma vez se tratar de uma pesquisa qualitativa, informase que foram entrevistados no total 49 usuários, sendo destes um com representação no Conselho municipal de Assistência Social em Belo Horizonte/MG e outro em Tobias Barreto/SE. Foram entrevistados 13 técnicos dos oito Centros de Referência de Assistência Social - Cras visitados e seis técnicos que atuam nas Gerências de Proteção Social Básica e coordenação da política de Assistência Social ou similar, totalizando 19 profissionais que trabalham nesse setor da política. Entrevistou-se ainda dos cinco municípios visitados três gestores da Assistência Social, sendo que os outros dois tratase de primeira dama que justificaram não ter agenda em decorrência de outros compromissos se fazendo representar pelos coordenadores e técnicos da Proteção Básica.

Todo o percurso metodológico da pesquisa envolveu a singularidade, a particularidade e a universalidade de nosso objeto, sendo necessário a essa pesquisa o aporte de categorias e conceitos de análise que, na perspectiva da dialética, é o fio condutor para o estudo de qualquer realidade sócio-histórica. O próximo capítulo tem por objetivo apresentar e aprofundar a respeito o referencial teórico adotado no desenvolvimento e na análise da pesquisa.

\footnotetext{
${ }^{24}$ Disponível em: $<$ http://portalpbh.pbh.gov.br/pbh/ecp/comunidade.do?evento=portlet\&pIdPlc=ecpTaxonomiaMenuPortal \&app=assistenciasocial\&lang=pt_BR\&pg=5568\&tax=18420>. Acesso em 9 de fevereiro de 2014 .
} 


\section{CAPÍTULO 2}

\section{As categorias de análise da pesquisa}

Este capítulo tem por objetivo apresentar e aprofundar as categorias de análise que foram o fio condutor para a compreensão sobre a Comunicação Pública junto aos usuários nos Cras. De acordo com o método dialético, as categorias são ontológicas, uma vez pertencerem à ordem do ser social, por exprimir formas e modos de ser que determinam uma sociedade e são reflexivas em decorrência de ser mediante aos procedimentos intelectivos próprios da abstração, que o pesquisador as reproduz teoricamente. São, portanto, de acordo com Netto (2011), históricas e transitórias tanto real quanto teoricamente.

Nessa perspectiva é necessário reconhecer o processo histórico que produziu e desenvolveu categorias tais como a questão social, as políticas sociais, a democracia, a cidadania, a cultura e o Estado liberal de democracia de massas, percebendo a intrínseca relação entre elas ${ }^{25}$ e como se realizam no atual contexto, definido como capitalismo monopolista, que é marcado pela financeirização e pela mundialização ${ }^{26}$ do capital. $\mathrm{O}$ capital, por sua vez, tem como prerrogativa a concentração e a centralização da riqueza em face da intensificação da pobreza com o apoio do Estado democrático e de direitos sob a hegemonia neoliberal. Essa fase do capitalismo, identificado por Harvey (1993) como acumulação flexível, configura a reação burguesa à crise do modelo taylorista/fordista e da regulação keynesiana da economia, gestada já na década de 1960, quando as economias centrais começaram a apresentar sinais de declínio do crescimento econômico, evidenciando o início da saturação daquele padrão de acumulação.

As décadas de 1980 e 1990 foram marcadas como um período de reestruturação tecnológica e organizacional capitaneado pela ofensiva burguesa, cujo acordo se

\footnotetext{
${ }^{25}$ Daí optou-se por não subdividir o capítulo de forma a assegurar a dinâmica reflexiva do método dialético que, no processo de abstração, requer que sejam estabelecidas as diferenças, as semelhanças, as articulações e os nexos que colaboram para a compreensão do objeto de estudo.

${ }^{26} \mathrm{O}$ termo mundialização é utilizado neste texto por representar uma análise critica à globalização do capital. A palavra globalização teve sua origem nas business schools norte-americanas, no inicio da década de 1980. Traz consigo a ideia de que a liberalização e a desregulamentação da economia são processos naturais, devendo todas as economias se adaptarem a esse processo. Ver Chesnais em "Mundialização: o capital financeiro no comando", publicado em Les Temps Modernes, n. 607, 2000 e reproduzido com a permissão do autor e da revista Outubro. Tradução de Ruy Braga. Disponível em: $<$ http://outubrorevista.com.br/wp-content/uploads/2015/02/Revista-Outubro-Edic\%CC\%A7a\%CC\%83o5-Artigo-02.pdf>. Acesso em: 11 set. 2015.
} 
estabeleceu no Consenso de Washington", 27 por meio do qual se pactuou pela apologia à privatização, transferindo para o mercado a tarefa de regulamentar os conflitos de interesses e de satisfazer as demandas sociais. O neoliberalismo surge como uma estratégia teórica e política de desmonte dos direitos trabalhistas e do Welfare State, passando as expressões da questão social a ser alvo de ações solidárias, além da emergência da filantropia e do terceiro setor nos anos de 1990 e de 2000.

Mota (2009) indica que as crises no capitalismo, além de intrínsecas a ele, são necessárias para sua reorganização. Como as crises ocorrem em decorrência do descompasso entre as condições de produção da mais-valia em relação às da sua realização (pois não basta produzir mercadorias), elas têm de se transformar em dinheiro, retornando ao incessante processo de acumulação do capital produção/circulação/consumo. Assim, após a revolução tecnológica, com sinais de esgotamento no setor energético (petróleo) e com a fragilização da organização dos trabalhadores e do socialismo real, o capitalismo monopolista entrou em outra fase: a da mundialização do capital, sustentada pelo neoliberalismo. Numa clara estratégia de aumentar os lucros em detrimento do aumento do trabalho morto ${ }^{28}$ a mundialização se faz com a intensificação de fusões e por meio da enorme concentração de oferta dos setores de alta tecnologia e de produção em escala. $O$ trabalho e as mercadorias passaram a ser desterritorializados e as condições e relações de trabalho foram precarizadas, alterando a vida, a organização e a resistência dos trabalhadores. Para Mota (2009), o capitalismo fez emergir um novo trabalho/trabalhador coletivo à base de uma nova divisão internacional e sociotécnica do trabalho, mantendo a parte nobre (planejamento, pesquisa, designers, etc.) nos países centrais e a parte do trabalho

\footnotetext{
${ }^{27}$ O Consenso de Washington ocorreu no ano de 1989 e contou com a participação de economistas de instituições financeiras situadas em Washington D.C. como o Fundo Monetário Internacional (FMI), o Banco Mundial e o Departamento do Tesouro dos Estados Unidos. Ali foram criadas um conjunto de medidas que se tornou a política oficial do FMI, em 1990, quando passou a indicado o "ajustamento macroeconômico" dos países em desenvolvimento que passavam por dificuldades.

${ }^{28}$ Em entrevista ao site Primeiro Conceito, o sociólogo Ricardo Antunes (2012) contribuiu com a análise de que o capital na atualidade traz embutidos novos modos de geração da mais valia (seja sob a forma absoluta e/ou relativa), ao mesmo tempo em que expulsa da produção muitos trabalhos que se tornam sobrantes. De acordo com ele estas modalidades de trabalho intensificam as formas geradoras do valor (mesmo que aparentemente não se expressem como valor), colaborando para o aumento de novos e velhos mecanismos de intensificação e de exploração do trabalho. Entretanto, como o capital só pode gerar mais-valor realizando alguma forma de interação entre trabalho vivo e trabalho morto (máquinas e equipamentos), ele busca incessantemente o aumento da produtividade do trabalho, "ampliando os mecanismos de extração do sobretrabalho em tempo cada vez menor, através da ampliação do trabalho morto corporificado no maquinário tecnocientífico-informacional (...) sem deixar de mencionar a crescente importância dos trabalhos de tecnologias de informação e comunicação no processo de valorização do capital". Disponível em: <http://www.primeiroconceito.com.br/site/?p=1582>. Acesso em: 11 jan. 2016.
} 
precário e sujo nos países periféricos, em função de a mão de obra ser mais barata, de os regimes de trabalho serem heterogêneos e de haver dispersão espacial e a não proteção dos riscos de trabalho. As mudanças no mundo do trabalho contemporâneo expressam o retorno à mais-valia absoluta (intensificação do processo de trabalho) e à mais-valia relativa (exigências na qualidade da produção), nas quais há "uma mudança de propriedade do capital e não a criação de novos meios de produção. O novo está menos na indústria e mais no papel do capital financeiro e capital bancário" (Behring, 2003, p. 54).

O neoliberalismo se orienta pela tese de que o mercado é o principal e insubstituível mecanismo de regulação social, devendo a intervenção do Estado ser mínima e restrita a três funções: garantir a segurança, assegurar as condições para que os indivíduos possam se defender de qualquer ofensa e o prover as obras públicas. Seu objetivo central é combater as políticas macroeconômicas de matriz keynesiana e a garantia dos direitos sociais, defendendo como meta a estabilidade monetária. A reestruturação produtiva vem sendo conduzida com o ajuste neoliberal, que requer a desregulamentação de direitos sociais, o corte dos gastos sociais e apelo ao mérito individual. No neoliberalismo, a orientação geral é pela flexibilidade para alcançar o máximo de produtividade da força de trabalho com o mínimo de custo.

Dessa forma, compete ao Estado sob orientação neoliberal se converter em ponto de apoio às empresas que se tornam organizações de governo da economia mundial, além de se orientarem pelos modelos do FMI e do Banco Mundial, que indicam a parte mais competitiva para a exportação, havendo contenção do mercado interno, bloqueio do crescimento dos salários, dos direitos sociais e diminuição do controle democrático. O atual estágio do capitalismo, portanto, hipertrofia as atividades de natureza financeira dotadas de extraordinária mobilidade espaço-temporal, tendo em vista as tecnologias da comunicação, a intensificação de fusões e os controles estataisnacionais, dirigindo o grande capital para a rentabilidade, e não para o atendimento de necessidades, produzindo-se, assim, novas manifestações da questão social. A questão social, longe de ser um problema social, um fato social ou um fenômeno social, uma vez que essas abordagens reduzem a sua compreensão por não vinculá-la à forma como a sociedade produz e reproduz as relações sociais, também não pode ser identificada como um problema exclusivo dos pobres que, por uma razão meritocrática, não obtiveram sucesso. Ou seja, por não terem méritos próprios, como ter capacidade ou 
inteligência, como defendia o laissez-faire (Adam Smith, 1776) não prosperaram num regime de concorrência.

Historicamente, antes do modo capitalista de produção, a pobreza e as desigualdades sociais tinham relação com a escassez relacionada ao baixo grau de desenvolvimento e às condições de produção. No capitalismo, o pauperismo e a miséria adquiriram uma nova lógica e dinâmica por estarem associadas à questão da produção e socialização da riqueza. De acordo com Castello (2006), a escassez passou a ser resultado de uma produção social, e não mais decorrente da ordem natural, podendo a pobreza e as desigualdades sociais serem relacionadas à divisão da sociedade em classes sociais e à existência da propriedade privada. O trabalho, por sua vez, é a atividade central: é por meio dele que a riqueza se produz e é regulada. No entanto, ao se instituir enquanto classe hegemônica, a burguesia excluiu os trabalhadores da vida política por considerar, dentre outras razões, que, em decorrência do baixo nível intelectual, seriam incapazes de atuar racionalmente no campo da política.

Por conseguinte, os trabalhadores se organizaram e lutaram, reivindicando soluções contra o pauperismo e em defesa da participação na vida política, a exemplo do movimento do Cartismo (1838) na Inglaterra, que propunha o sufrágio universal para todos os homens adultos; renovação anual do parlamento, a fixação de remuneração parlamentar, para que os candidatos sem recursos pudessem igualmente exercer o mandato, as eleições por escrutínio secreto, circunscrições eleitorais iguais, possibilitando representações equitativas e a abolição da disposição que dá elegibilidade apenas aos proprietários de terra, dando a todos o direito à elegibilidade. A entrada dos operários organizados no cenário político, por meio de várias lutas, gerou o rompimento com "o domínio privado nas relações entre capital e trabalho, extrapolando a questão social para a esfera pública, exigindo a interferência do Estado para o reconhecimento e a legalização de direitos e deveres dos sujeitos sociais envolvidos” (Iamamoto, 2001, p. $66)$.

A questão social, portanto, mais que pobreza, desigualdade e meritocracia, significa as contradições inerentes ao capitalismo manifestadas no cotidiano, as quais os trabalhadores exigiram outros tipos de intervenção, além da caridade e da repressão. De acordo com Iamamoto e Carvalho (2003, p. 77) a questão social significa "as expressões do processo de formação e desenvolvimento da classe operária e de seu ingresso no cenário político da sociedade, exigindo seu reconhecimento como classe por parte do empresariado e do Estado". A cada fase do capitalismo a questão social se expressa de 
diferentes formas, não se tratando, na atualidade de uma nova questão social, mas de manifestações da questão social que decorrem da reestruturação do mundo do trabalho e se apresentam no século XXI com as seguintes características: desemprego estrutural; precarização e casualização do trabalho; terceirização; trabalhos precários; novos modelos de organização e gestão do trabalho, desmonte sindical, perda de direitos trabalhistas e sociais. Logo, para Behring e Santos (2009, p. 271), a questão social pode ser compreendida na atualidade como:

\begin{abstract}
expressão das contradições inerentes ao capitalismo que, ao constituir o trabalho vivo como única fonte de valor, e, ao mesmo tempo, reduzi-lo progressivamente em decorrência da elevação da composição orgânica do capital - o que implica um predomínio do trabalho morto (capital constante) sobre o trabalho vivo (capital variável) - promove a expansão do exército industrial de reserva (ou superpopulação relativa) em larga escala.
\end{abstract}

As necessidades dos trabalhadores mais pobres têm sido enfrentadas historicamente de forma diferenciada a cada período. De acordo com Pereira (1996), desde o século XIV existiam intervenções públicas que visavam o atendimento aos indigentes, inclusive a repressão a vagabundagem. $\mathrm{Na}$ fase do capitalismo concorrencial, inicialmente as necessidades eram atendidas por meio das associações comunais e principalmente religiosas, que legitimavam a esmola, o asilo e alguns cuidados com a saúde. Nesse período, havia uma distinção entre os pobres merecedores e os não merecedores de assistência. Os merecedores eram aqueles não aptos ao trabalho, tais como crianças, doentes, deficientes físicos e viúvas. Os não merecedores eram os que estavam aptos ao trabalho e, caso não estivessem incorporados ao mercado de forma temporária ou permanentemente, eram compreendidos como mendigos e vagabundos. A legislação era severa e repressiva, sendo estes açoitados, marcados com ferro e condenados à morte, ou enviados, a partir do inicio do século XIX, para as casas de trabalho ou de coerção para a prática de trabalhos forçados.

Para Boschetti (2003), a questão entre o (não) trabalho e a assistência como política governamental se dá, desde os primórdios do capitalismo, de forma tensa e não resolvida, sendo que essa condição vem atravessando séculos e fronteiras. As primeiras expressões dessa oposição se localizam na relação entre a Lei dos Pobres ${ }^{29}$ e a Lei

\footnotetext{
${ }^{29}$ A Lei dos Pobres foi criada em 1601, no final do reinado da Rainha Elizabeth. Caracterizava-se pela oposição entre o trabalho e a assistência, sendo que os critérios de atendimento eram: ter um domicílio fixo e ser incapaz para trabalhar. Dessa forma, eram atendidas as pessoas que não tinham condições de trabalhar. Quanto às pessoas aptas ao trabalho, caso não estivessem trabalhando, eram submetidas a severas punições dependendo do grau de insubordinação (julgamento moral): poderiam receber como punição desde o enforcamento ao encaminhamento para as Casas de Correção para o trabalho forçado,
} 
Speenhamland, ${ }^{30}$ uma vez que enquanto a primeira induzia o trabalhador a aceitar qualquer trabalho por qualquer salário, a segunda assegurava proteção ao trabalhador, permitindo a ele negociar o valor de sua força de trabalho, impondo um limite à exploração, ainda que restrito ao mercado. De acordo com Polanyi (2000, p. 100 apud Boschetti, 2003, p. 55), a Lei Speenhamland "introduziu uma inovação social e econômica que nada mais era que o direito de viver e, até ser abolida, em 1834, ela impediu efetivamente o estabelecimento de um mercado de trabalho competitivo".

A proclamação da segunda Lei dos Pobres em 1834 marcou, portanto, o predomínio do primado liberal do trabalho, mais precisamente do assalariado, isto é, prevaleceu a concepção de que o homem deve manter a si e a sua família com os ganhos de seu trabalho, não havendo ponderação em relação ao salário quanto a atender todas as necessidades do homem, bem como se há trabalho para todos. Tem-se, portanto, de acordo com Boschetti (2003), um movimento circular: a mesma particularidade que dificulta o reconhecimento e a materialização do direito se alimenta e se reproduz da condição do não direito. A proteção, o amparo, a habilitação e a garantia de renda mínima destinam-se apenas àqueles cuja situação não permite trabalhar, ou seja, aqueles compreendidos como os bons pobres. Os demais pobres, aptos ao trabalho e vistos como oportunistas e vagabundos, uma vez que não se "dispõem" a exercer um trabalho, são repelidos das ações assistenciais ou, em troca, submetidos ao trabalho obrigatório. De acordo com Faleiros (1980), tem-se aí uma coerção para o trabalho ao estabelecê-lo como moeda de troca para se acessar algum tipo de assistência, além de existir uma culpabilização do indivíduo por sua situação, legitimada por critérios morais, cuja ideologia se afirma na naturalização da existência de ricos e pobres, e não como resultado do tipo de produção existente.

Percebe-se que as concepções sobre a pobreza também são construídas historicamente. Na atualidade, uma compreensão vigente é a de que os pobres são aqueles que, de modo temporário ou permanente, não têm acesso a um mínimo de bens e recursos, sendo excluídos, em graus diferenciados, da riqueza social. Nesse sentido, a exclusão social deve ser compreendida como parte integrante da dinâmica do

onde recebiam em seus corpos uma marca feita a ferro em brasa para que fossem sempre identificados em qualquer lugar e circunstância como "um não cidadão".

${ }^{30}$ A Lei Speenhamland foi criada em 1795 na Inglaterra e consistiu em um sistema de abonos em complementação aos salários, cujo valor se baseava no preço do pão, independente de critérios de domicilio ou incapacidade para o trabalho. 
capitalismo, estando o indivíduo não só excluído do modo de produção e do usufruto da riqueza socialmente produzida, mas, também, do plano espiritual, moral e político.

Nessa perspectiva, a categoria subalternidade possibilita ampliar o entendimento sobre a classe trabalhadora, uma vez que é possível aprofundar com maior clareza suas diferenciações internas. Trata-se,

de uma concepção ampla na qual tanto incluímos trabalhadores cujo trabalho não é suficiente para garantir seu próprio sustento e o de sua família, como os desempregados e grupos sem condições de obtenção de meios para subsistir. (Yasbek, 2003, p. 70)

As primeiras iniciativas de apoio ao trabalhador e à sua família identificadas como políticas sociais não são determinadas historicamente com precisão, mas afirmase que elas decorrem da confluência dos movimentos de ascensão do capitalismo com a Revolução Industrial, das lutas de classe e do desenvolvimento da intervenção estatal. Sua origem é comumente relacionada aos movimentos de massa socialdemocratas e ao estabelecimento dos Estados-nação na Europa ocidental do final do século XIX, mas sua generalização situa-se na passagem do capitalismo concorrencial para o monopolista, em especial na sua fase tardia, após a Segunda Guerra Mundial. Portanto, o contexto histórico que marca a existência das políticas sociais está associado à constituição da sociedade burguesa, no seu modo capitalista de produzir e reproduzir-se, mas não se dá exatamente nos primórdios do capitalismo, mas "quando tem-se um reconhecimento da questão social inerente às relações sociais nesse modo de produção, vis à vis ao momento em que os trabalhadores assumem um papel político e até revolucionário" (Behring, 2000, p. 21).

Pereira (2009) indica que a expansão das políticas sociais está associada a três marcos orientadores, são eles: a revisão conceitual da relação entre Estado e mercado elaborada por John Maynard Keynes, motivado pela Crise de 1929; as postulações sobre Seguridade Social, preconizadas pelo relatório organizado por Willian Beveridge; e pela formulação da "teoria trifacetada da cidadania" de T. H. Marshall. Essas concepções propiciaram a experiência de construção do "Welfare State" em alguns países da Europa ocidental, a partir da Segunda Guerra Mundial. Em seus primórdios, o liberalismo compreendia que o interesse dos indivíduos em melhorar suas condições de vida maximizaria o bem-estar coletivo. Assim, os indivíduos seriam conduzidos por uma mão invisível - o mercado - que promoveria um fim que não faria parte de sua intenção inicial. Ao Estado competiria garantir a base legal para que o mercado livre gerasse 
benefícios aos homens, sendo, portanto, um Estado mínimo com apenas três funções: a defesa contra os inimigos externos; a proteção de todo o indivíduo de ofensas dirigidas por outros indivíduos; e o provimento de obras públicas, que não pudessem ser executadas pela iniciativa privada.

A Crise de 1929, ou a Grande Depressão, foi a maior crise econômica mundial que o capitalismo enfrentou até aquele momento. Diante daquela realidade, Keynes começou a se afastar da ortodoxia liberal representada pela Lei de Say. Para ele, a "mão invisível" não produzia a harmonia apregoada entre o interesse egoísta dos agentes econômicos e o bem-estar geral. Em busca de seu ganho máximo, o comportamento individual dos agentes econômicos - produtores, consumidores e assalariados - pode gerar crises, a despeito do bom funcionamento das forças automáticas do livre mercado, e estas advêm de insuficiências de demanda efetiva. Os níveis de produção e emprego são determinados pela igualdade entre ofertas e demandas agregadas, sem a garantia de que todos aqueles que queiram trabalhar possam efetivamente encontrar emprego. Para escapar das armadilhas recessivas, evitar a acumulação improdutiva e gerar demanda efetiva, Keynes, a partir de reflexões oriundas da Crise de 1929, propôs a ação do Estado para eliminar a carência de demanda efetiva em momentos de recessão e desemprego, por meio da geração de um déficit orçamentário e da emissão de títulos para extrair a "renda não gasta" do setor privado e, com ela, garantir que as máquinas ociosas voltassem a operar.

Com base na crítica ao modelo birmackiano ${ }^{31}$ de seguro social, é publicado o relatório Beveridge, em 1942, na Inglaterra, sob a referência "Seguro Social e Serviços afins" que propunha a constituição de um sistema complexo e completo de proteção social na ausência do salário que deveria ser fruto do pleno emprego. De acordo com Faleiros (1980), o modelo beveridigiano visava à garantia de um rendimento quando ao trabalhador ocorressem situações que o impedissem de extrair o seu salário, a exemplo do desemprego, doença, acidente, aposentadoria ou morte daqueles membros que supriam as necessidades do grupo familiar. Ainda, haveria de serem consideradas as situações que gerassem despesas extraordinárias, tais como despesas com nascimento, morte, casamento, dentre outros. A Seguridade Social proposta significava para esse

\footnotetext{
${ }^{31} \mathrm{O}$ modelo bismarckiano de seguro social foi o sistema implementado por Bismarck na Alemanha no final do século XIX. Tal modelo introduziu caixas estatais, em geral regionalizadas com controle central, de seguro saúde, de seguro-velhice e de seguro-acidente com contribuições compulsórias de empregados, patrões e subsídios do Estado. Os trabalhadores de renda mais baixa eram isentos de contribuição. (Faleiros, 2000).
} 
modelo a segurança a um rendimento mínimo, sendo que estes deveriam cessar tão cedo possível.

Em 1949, T. H. Marshall (1967) formula o conceito de cidadania num contexto de ampla utilização das estratégias fordistas-keynesianas, imprimindo um novo estatuto teórico para a política social. Porém, ao vincular a cidadania como parte dos princípios liberais, terminou por legitimar a desigualdade no capitalismo ao afirmar existir compatibilidade entre este e a desigualdade de classes, bastando apenas que se preservasse uma igualdade básica dada pelo conjunto de alguns direitos, tais como: direitos civis: direito de ir e vir, de imprensa, de fé e de propriedade; direitos políticos: de votar, de ser votado e os direitos sociais - isto é, o acesso a um mínimo de bem-estar econômico e de segurança. Muitas críticas foram realizadas ao trabalho de Marshall quanto à linearidade, generalização da experiência inglesa e à subsunção da desigualdade à cidadania. No entanto, é oportuno considerar a relação realizada entre política social e cidadania, haja vista que essa não é uma relação imediata, afinal, as políticas sociais decorrem do conflito entre classes, não se tratando, como indicou Coimbra (1987), da hipótese do engodo ou da hipótese da conquista, ${ }^{32}$ e sim de uma totalidade na qual as políticas sociais devem ser compreendidas como a síntese de múltiplas determinações. Portanto, de acordo com Behring (2000) e Faleiros (1980), a política social é sempre um resultado que envolve mediações complexas, decorrentes de relações socioeconômicas, políticas, culturais e de sujeitos políticos e forças sociais que se movimentam e disputam hegemonia nas esferas estatal, pública e privada. Ou ainda, como apontou Raichelis (2000, p. 60), podem ser compreendidas como a "luta dos trabalhadores urbanos e rurais pela apropriação da riqueza socialmente produzida, sendo as demandas articuladas junto ao Estado e patronato que no enfrentamento da questão social, formulam as políticas sociais".

A experiência do Welfare State indicou, mesmo com vários padrões de proteção social, que as políticas sociais decorrem da relação entre as classes sociais e as condições econômicas gerais que interferem nas opções políticas e econômicas dos governos. Daí a variação quanto à cobertura ser mais ou menos universal e o padrão de financiamento ser redistributivo ou não, contributivo ou não. Contudo, duas questões

\footnotetext{
${ }^{32}$ Marcos Coimbra (1987) chama a atenção sobre os simplismos das análises bipolares sobre as políticas sociais ser resultado da interação entre o Estado e as classes trabalhadores. Esse tipo de análise levaria ou à hipótese do engodo, visão economicista na qual a política social é apenas fator de acumulação e de cooptação dos trabalhadores, ou à hipótese da conquista, visão politicista na qual a política social é decorrente simplesmente da pressão dos trabalhadores sobre o Estado capitalista.
} 
são centrais: a primeira é que as políticas sociais não conseguem oferecer igualdade de condições, sendo limitadas ao combate à desigualdade, não redistribuindo efetivamente a riqueza socialmente produzida; a segunda é que há um deslocamento do conflito entre o capital e o trabalho para o interior do Estado quando este assume o papel de gestor das medidas anticrise.

A análise histórica tem possibilitado perceber o quanto a questão social e as políticas sociais possuem uma relação estreita com a democracia e com o exercício da cidadania, em que pese os limites da democracia liberal e a contradição entre política social e direitos sociais, pois a formulação e execução dos serviços sociais relativiza a perspectiva universal dos direitos sociais, dado que no Estado "há uma forte tendência à segmentação e setorialização das demandas, bem como de tecnocratizar questões econômico-políticas, despolitizando-as”, como apontou Behring (2000, p. 35).

Coutinho (2000) afirma que, na modernidade, ocorre uma profunda articulação entre cidadania e democracia, sendo o melhor conceito que expressa a democracia a cidadania, uma vez que democracia implica também no acesso e na apropriação aos bens socialmente produzidos por parte dos indivíduos. Ambas decorrem de processos históricos, pois a cidadania e a democracia não são obtidas pelos indivíduos de forma determinada, por períodos indeterminados, e sim resultam de uma luta permanente, travada pelas classes sociais e segmentos subalternizados, implicando, assim, um processo histórico de longa duração. Portanto, a democracia tem relação não só com as modificações da política, mas também com a economia e com a questão social, sendo minimalista a concepção liberal quando aborda que a democracia tem relação apenas com as regras formais que definem os processos eleitorais.

Nesse sentido, Coutinho (2000, p. 129) afirma que a democracia é um valor universal, ${ }^{33}$ pois "deve ser entendida não como algo que se esgota em determinada configuração institucional, mas sim como processo. (...) A democracia é soberania popular, é construção de uma comunidade participativa, é igualdade". Em concordância com a ideia de que democracia e cidadania decorrem de processos históricos e da relação das forças políticas em presença, faz-se necessário compreender a especificidade da dinâmica brasileira, dado que a estrutura social capitalista em nosso

\footnotetext{
${ }^{33}$ Em uma entrevista publicada no livro Contra a Corrente - Ensaios sobre democracia e socialismo, editora Cortez, 2000, Coutinho afirma que se pudesse, naquele momento mudaria o titulo do artigo que publicou em 1979 "A democracia como um valor universal" para a "democratização como um valor universal". Esse apontamento do autor tem relação com Lukács que ao falar de democracia preferia falar em democratização visto tratar, ontologicamente, de um processo e não de um estado.
} 
país possui vícios especificamente brasileiros, sendo a exclusão social o grande problema nacional, como afirmou Coutinho (2000, p. 129):

[...] no Brasil, sempre vivemos processos de modernização excludentes, que consistem essencialmente em arranjos entre frações das classes dirigentes, com a permanente tendência a excluir a grande massa da população de uma participação tanto nas decisões políticas quanto nos benefícios da modernização e do progresso econômico. Esse tipo específico de capitalismo brasileiro gerou um fenômeno extremamente perverso: a exclusão das grandes maiorias da vida nacional.

Outros autores aprofundam sobre o fenômeno da exclusão de frações da classe trabalhadora a bens e serviços, indicando três processos de envergadura histórica que influenciam tanto o exercício da cidadania na atualidade como a própria democracia, que podem ser identificados como: o sentido da colonização, o peso do regime escravo e a peculiaridade do desenvolvimento desigual e combinado. O sentido da colonização desvenda as peculiaridades da Colônia, do Império e da República ao sugerir uma acumulação originária dos excedentes obtidos por meio de um mercantilismo, seja por meio de guerras contra os povos, da pirataria, das diversas formas de trabalho compulsório e outros meios de acumulação mercantil. É a reprodução do capital numa perspectiva de concentração e centralização em escala mundial. "Cada país, dependente, subordinado ou associado, se revela mais uma vez um subsistema altamente determinado pelos movimentos internacionais do grande capital" (Ianni, 1992, p. 57).

A escravatura dos negros, com início no século XVI, entrou pelo século XIX e tudo mais dependeu principalmente dela. Foi a única coisa organizada da sociedade colonial. Foram séculos de trabalho escravizado, que produziram um universo de valores, padrões, ideias, doutrinas, modo de ser, pensar e agir, influindo sobre o conceito de trabalho e sobre a concepção de algumas ocupações vistas de forma pejorativa e desabonadora. Como fato político, a abolição marcou o início de uma nova ordem. Ainda que fosse um trabalhador livre, o negro era considerado um cidadão de segunda categoria, mas superior aos índios. Ele aparece como um fator dinâmico da vida social, sendo um aliado do branco, que, por sua vez, prosperou. Os índios ficaram fadados, na dinâmica da vida social, ao desaparecimento. Aos negros libertos, não foram asseguradas escolas, terras ou empregos. Muitos regressaram às fazendas de origem ou a fazendas vizinhas, retomando o trabalho em troca de baixos salários. Alguns se dirigiram para as cidades, reforçando as filas dos sem emprego fixo. Onde havia uma economia mais dinâmica, a exemplo de São Paulo, os novos empregos eram ocupados pelos imigrantes europeus. Dessa forma, os negros desempenhavam 
atividades mais brutas e mal remuneradas. Coube à população negra enfrentar, por conta própria, o desafio da ascensão social, e, de acordo com Carvalho (2013), fazendo-a por rotas originais, como o esporte, a música e a dança. Ainda de acordo com Carvalho (2013, p. 21), o Brasil chegou ao fim do período colonial com a maioria da população excluída dos direitos civis e políticos e sem a existência de um sentido de nacionalidade. Mesmo a independência do país não teve participação popular significativa. Não houve experiência política anterior que preparasse o individuo para obrigações cívicas e políticas. E, mesmo com a proclamação da república, não se pode dizer que os senhores fossem cidadãos, a julgar que lhes faltava "o próprio sentido da cidadania, a noção de igualdade de todos perante a lei (...) em suas mãos a justiça, a principal garantia dos direitos civis, tornava-se simples instrumento do poder pessoal".

Com a 'Revolução'34 de 1930, as mudanças que vinham ocorrendo foram orientadas politicamente, tendo o Estado à frente da consolidação do desenvolvimento social. De acordo com Ianni (1992), estava em marcha uma singular revolução pelo alto. Pessoas, interesses, grupos, diretrizes no âmbito do poder estatal, tudo foi remanejado de forma a alterar o poder estatal. Por décadas, em manifestações sociais, econômicas, políticas e culturais diversas, díspares e frequentemente contraditórias, a classe dominante brasileira se desdobrou, realizando uma revolução lenta e segura, a única que temos experimentado em toda a nossa vida nacional. Assim, afirma-se ter ocorrido uma metamorfose do senhor-colonial em senhor-cidadão, uma vez que a democracia não era uma condição geral da sociedade. Faziam parte desta somente os estamentos, ou seja, aqueles indivíduos agregados no desfrute de uma série de vantagens vinculadas ao intercâmbio social. Por meio da junção das ideias liberais e da prática patrimonialista, garantindo os privilégios estamentais, foi-se constituindo o Estado brasileiro, sendo que, nessa época, desenvolveu-se a noção de uma política econômica orientada para o desenvolvimento econômico, envolvendo o Estado em atividades que deveriam ser assumidas pela iniciativa privada.

$\mathrm{O}$ terceiro processo que influencia a cidadania e a democracia na atualidade tem relação com o desenvolvimento desigual e combinado que vem atravessando a história do país, caracterizando toda a formação social brasileira. A combinação dos ciclos econômicos com os surtos de povoamento e com as expansões das frentes pioneiras no

\footnotetext{
${ }^{34}$ Muitos autores entendem não se tratar de uma revolução, mas sim de um processo de alternância de hegemonia entre a classe dominante. No entanto, não há discordância sobre este período ser um marco para a república no Brasil e que suas bases influem ainda o presente.
} 
extrativismo, na pecuária, na agricultura, na urbanização e na industrialização tem contribuído para as mais diversas e contraditórias formas de organização da vida e do trabalho.

Uma das contradições tem relação com os direitos sociais. Até a Primeira República, as práticas assistenciais foram exercidas por algumas irmandades religiosas oriundas da época colonial, que ofereciam a seus membros certidão de nascimento, apoio para tratamentos de saúde, auxílio funerário, empréstimos e mesmo pensões para viúvas e seus filhos.

O período de 1930 a 1945 foi marcado, dentre outros acontecimentos, pela aprovação da legislação social. O país passou a experimentar outra estrutura assistencial, sem haver, no entanto, um rompimento com a cultura já instituída, centrada na subalternização do sujeito. Tem-se, nesse período, o marco das políticas sociais no Brasil. Carvalho (2013, p. 110) aponta para a inversão no processo de conquista de cidadania em relação à experiência da Inglaterra, analisada por T. H. Marshall, uma vez que "os direitos sociais, no Brasil, saem na dianteira" em comparação aos demais. Para o autor, essas mudanças decorreram de um período de pouca participação política e de precária vigência dos direitos civis. "Este pecado de origem e a maneira como foram distribuídos os benefícios sociais tornaram duvidosa sua definição como conquista democrática". A forma como se instituiu o acesso aos benefícios, privilegiando inclusive os trabalhadores urbanos por meio dos sindicatos, que funcionavam como órgãos consultivos e técnicos do governo, criou aquilo que Wanderley G. dos Santos (1994) cunhou como 'cidadania regulada', isto é, uma cidadania que se orienta por uma lógica de restrições políticas em detrimento da adoção de um código de valores políticos universalistas.

Teixeira (1989) compreende tratar de uma 'cidadania invertida', pois o individuo se reconhece, em relação com o Estado, como um não cidadão, uma vez que há uma perda de direitos inerentes à condição de cidadania, a exemplo do direito político. Yasbek (2003, p. 50) colabora que "o apoio na matriz do favor, do apadrinhamento, do clientelismo, do mando, são formas enraizadas na cultura política do país, sobretudo no trato com as classes subalternas, o que reproduz relações de dependência”. Trata-se, portanto, de uma concepção da política social como privilégio, e não como direito, reeditando nas terras brasileiras a meritocracia, a culpabilização do sujeito e o primado liberal. 
De acordo com Neves (2008), no Brasil a cultura política é híbrida, ambivalente e tem no clientelismo um limite para a construção da democracia no país, uma vez que este se dá por meio de: i) relações assimétricas, ou seja, um detendo o poder sobre o outro; ii) se funda no favor; iii) e na troca ou apoio pela ajuda recebida da parte do patrão. O clientelismo pode ser caracterizado na relação entre duas pessoas, constituindo uma díade, e se sustenta no clientelismo tradicional "que busca a troca de favores entre duas pessoas, favorecendo os interesses pessoais e privados, típico das sociedades rurais" (Neves, 2008, p. 39). Ele pode ocorrer por meio de relações horizontais - constituído por relações de interesses pessoais e por meio de relações verticais, que são compreendidas como uma relação patrão-cliente, sendo totalmente assimétricas no que diz respeito ao status e ao poder, estabelecendo-se com bastante desigualdade. Essas relações, embora sejam mutáveis, estão, na maioria das vezes, associadas a benefícios materiais entre o patrão e o cliente, caracterizando-se em favor para atender uma necessidade do cliente.

Outro tipo de clientelismo é o de massa e partidário, realizado nas instituições políticas, nos partidos e nas organizações públicas. Tem em comum com o do tipo díade o fenômeno da troca, do favor e do paternalismo. Neves (2008) afirma que nas organizações de Estado, mesmo com alto grau de burocracia e impessoalidade, realizam-se a troca e o favor político, que se caracterizam como favores de massa, coletivos e corporativos. O clientelismo partidário é marcado por sua permanência no Estado, sendo as lideranças partidárias os mediadores que se colocam como pontes entre a população e o governo, estabelecendo a ideia da importância da manutenção da ordem como possibilidade de continuidade da troca. Com a modernização e a urbanização da sociedade, o clientelismo se transformou, e, na sua base, encontra-se a reedição do mito fundador (Chauí, 2000) como aquele que não cessa de procurar novos meios para se exprimir, mas que objetiva a manutenção de um vínculo interno do passado como origem. Segundo Neves (2008, p. 43)

\footnotetext{
A novidade do clientelismo estaria associada à ideia de que os novos patrões seriam os políticos profissionais e as lideranças partidárias que utilizam mecanismos institucionais para reproduzir a lógica do cliente/patrão, da troca e do favor em detrimento dos direitos conquistados.
}

Chauí (2003, p. 10) considera que é por meio da ideologia que se unifica o pensamento, a linguagem e a realidade, de forma a obter a identificação de todos os sujeitos sociais com uma imagem particular universalizada, isto é, a imagem da classe 
dominante. Daí tem-se a impressão que "ninguém exerce o poder, porque este emana da racionalidade do mundo organizado, ou da competência dos cargos e funções que estão ocupados por homens determinados". Gramsci (2001) afirma que o predomínio ideológico é resultante de um processo de hegemonia das classes dominantes sobre a classe subalterna na sociedade civil. A noção de hegemonia propõe uma nova relação entre estrutura e superestrutura e tenta se distanciar da determinação da primeira sobre a segunda, mostrando a centralidade das superestruturas na análise das sociedades avançadas. Nesse contexto, a sociedade civil adquire um papel central, bem como a ideologia, que aparece como constitutiva das relações sociais. Desse modo, uma possível tomada do poder e construção de um novo bloco histórico ${ }^{35}$ passa pela consideração da centralidade dessas categorias. No entanto, a busca por hegemonia também se dá no interior das classes dominantes quando frações dessa classe exercem domínio e controle sobre outras frações internas e sobre frações de classe aliadas. Segundo Carnoy (1986, p. 95), a compreensão gramsciana indica que,

[...] a hegemonia compreende as tentativas bem sucedidas da classe dominante em usar sua liderança política, moral e intelectual para impor sua visão de mundo como inteiramente abrangente e universal, e para moldar os interesses e as necessidades dos grupos subordinados. [...] A hegemonia não é uma força coesiva. Ela é plena de contradições e sujeita ao conflito.

No entanto, ainda de acordo com Gramsci (2001), é por meio da cultura que se realiza o desenvolvimento da consciência crítica do ser social. Ao se tornar um ser consciente de sua existência individual, o homem não deixa de se conscientizar de sua existência social: ele pode distanciar-se dentro de si, na sua imaginação, e colocar-se no lugar de outra pessoa, comunicando suas sensações, emoções, expandindo conteúdos intelectuais. Ele pode formular ideias e propostas de crescente complexidade e comunicá-las aos outros indivíduos como possibilidades futuras, sendo essa a base da cultura popular que numa sociedade de classes ocorre quando há um reconhecimento dos dominantes.

$\mathrm{Na}$ contemporaneidade, um determinante que tem influído na relação entre cultura, democracia e cidadania são as inovações tecnológicas no setor das comunicações, uma vez que têm sido, simultaneamente, causa e efeito da mundialização

\footnotetext{
35 Gramsci desenvolveu o conceito de bloco histórico com a perspectiva de explicar teoricamente o processo mediante o qual uma classe subalterna adota uma estratégia de "guerra de posição" e remodela as forças sociais visando à construção de um novo Estado. Trata-se de uma articulação interna de uma situação histórica precisa. É um conceito dialético na medida em que há uma interação entre estrutura (conjunto das relações materiais) e superestrutura (conjunto das relações ideológico-culturais).
} 
do capital, em função das indústrias da comunicação que são capazes tanto de organizar como também expressar o imaginário do movimento, controlando seus significados. Para Lima (2004), a mundialização desencadeia no setor das comunicações consequências que incidem desde a economia política do setor, a natureza da comunicação e até sua semântica, visto estarmos na era das comunicações.

Essa organização técnico-econômica, que extingue fronteiras políticas, econômicas e ideológicas, impondo pactos, alianças estratégicas internacionais e que intensifica a exploração do trabalhador, vem promovendo um controle sobre todas as atividades sociais e se sustenta, inclusive, por meio de uma construção sociolinguística compatível com a ideologia neoliberal, que se impõe também por meio da virtualidade, por recortes denominados de discursos, promovendo um ethos midiatizado, sendo obtida a hegemonia da classe dominante "não com mera racionalidade, mas também com dissimulações, simulações, recursos mágicos e afetos nada racionais" (Sodré, 2009, p. 35).

A revolução digital tem provocado alguns diferenciais em relação a outros tempos, como, por exemplo, a dificuldade de se fazer distinções nítidas entre o mundo da mídia, o mundo da comunicação, o mundo que poderíamos denominar de cultura de massas e o mundo da publicidade, uma vez que as informações circulam e migram de uma mídia a outra sem se saber ao certo a origem da fonte ou mesmo a que se objetivam. Ou seja, a era digital permite a junção da esfera da informação, da publicidade e da cultura de massa, a mescla do texto, do som e da imagem ${ }^{36}$ e ainda, a produção da informação que pode ser realizada, à princípio, por qualquer individuo e

\footnotetext{
${ }^{36}$ A origem e o desenvolvimento dos meios de comunicação estão articulados aos contextos econômicos, políticos, sociais e culturais e tem características muito próprias. Cada mídia reflete as possibilidades não só da criação do meio, mas também de seu acesso e de seu uso, daí inclusive a predominância de um determinado tipo de linguagem. Recorremos a alguns exemplos a fim de contribuirmos na elucidação da magnitude da era digital, uma vez que esta reúne em si vários recursos de comunicação e de linguagem, possibilitando à sociedade, de um modo em geral, uma dinamicidade nunca antes registrada na história. No uso do telégrafo era necessário, além da tecnologia, incluído os cabos, uma pessoa que dominasse um código e estivesse dotada de estrutura para fazer chegar a mensagem a seu destino final. Na impressão gráfica, o predomino da linguagem escrita propiciou uma expansão das informações, mas com um recorte para o acesso. No uso do rádio, a linguagem oral possibilita um maior acesso da população às informações, desde, é claro, que obtenham as condições físicas para isso, tais como o meio, a eletricidade e o alcance. Cada mídia, a exemplo do telefone, do cinema e da televisão, proporcionou e ainda proporciona experiências de impacto, sejam elas coletivas ou individuais, bem como a combinação de vários recursos de linguagem. No entanto, é a partir da convergência aplicada ao desenvolvimento tecnológico digital, que integrou textos, números, imagens, sons e diversos elementos da mídia, que a computação e a comunicação se vincularam, possibilitando à humanidade viver uma experiência como se não houvesse fronteiras espaciais ou temporais. Para aprofundar a respeito da história da mídia, sugerimos a leitura de Uma história social da mídia. De Gutemberg à internet, de Asa Briggs e Peter Burke (Rio de Janeiro: Jorge Zahar Editor, 2004).
} 
lançada em rede. No entanto, esse universo de muitas possibilidades comunicacionais não quer dizer garantia total de acesso, nem transparência das informações ou democratização do conhecimento, uma vez que sob o capitalismo a informação se faz essencialmente como mercadoria, afinal, a tendência é tornar a informação cada vez mais gratuita por meio do rádio, da televisão ou da imprensa, pois, na verdade, quem paga a informação é a publicidade, que vende consumidores aos anunciantes, fechando um ciclo de que a informação é comprada e vendida com o objetivo de se obter lucros.

Adorno e Horkheimer (1985), ao final dos anos de 1940, denunciaram que toda a práxis da indústria cultural transferia a motivação do lucro às criações espirituais, sendo que o vento que arrasta para a cultura é o vento do lucro capitalista. Nessa perspectiva, Ramonet (2009) entende que o discurso atual, ou seja, a linguagem utilizada nos vários meios de comunicação e que aos poucos é incorporada e naturalizada pela sociedade, caracteriza-se por ser um discurso rápido, com vistas a evitar o tédio. Tudo é feito a partir de um modelo publicitário que utiliza artigos curtos, frases breves e títulos impactantes, com elementos de espetacularização e/ou de dramatização, para que se provoquem fortes emoções. A comunicação é construída de forma bem elementar e simples, por meio de um discurso infantilizante, ao articular a simplicidade e a brevidade de uma maneira emotiva, com vistas a possibilitar a compreensão da maioria dos indivíduos.

Diante dessa complexa teia que quer naturalizar a lógica do mercado, MartínBarbero (2013) considera que o processo comunicativo deve ser visto em sua totalidade e de forma contínua, ou seja: produção, recepção, meio e mensagem. Para o autor, ao considerar todo o processo pelo qual se dá a comunicação, é possível perceber que, mesmo com a alienação social promovida pelo capitalismo, o receptor não está impossibilitado de filtrar as mensagens que se dão por meio de mediações, afinal, a comunicação e a cultura são categorias intercambiáveis. É preciso reconhecer que as manifestações culturais não se limitam apenas às relações sociais de que são produto, pois possuem dinâmica própria e são, em essência, criativas.

Martín-Barbero (2013) entende que as mediações são um campo fértil das apropriações e ressignificados dos receptores em relação à mensagem produzida. Para ele, é no terreno das mediações que se dão as articulações entre práticas de comunicação e movimentos sociais, visto que elas integram cultura e comunicação na processualidade do cotidiano, por ser a cultura vivida na sua dinamicidade comunicativa. Assim, na 
relação entre a produção da mensagem para o receptor, a mediação seria o pano de fundo de onde as manifestações comunicacionais alimentam as tramas culturais.

Em relação às particularidades dos processos comunicacionais na América Latina contemporânea, Martín-Barbero (2013) afirma que o debate sobre a identidade continua em aberto e que existe uma razão dualista: uma delas refere-se a um nacionalismo populista, obcecado pelas raízes, uma identidade a ser buscada, dado que a maioria da população encontra-se em espaços urbanos; a outra razão aponta para um progressismo iluminista, que continua a ver no povo, em sua natureza indolente e supersticiosa, um obstáculo para o desenvolvimento. O que ele defende é que essas perspectivas retiram dos grupos subalternizados, a exemplo dos índios e dos camponeses $^{37}$ já envoltos no capitalismo, sua capacidade de se desenvolver em suas culturas. Ou seja, embora esses grupos tenham vivenciado e vivenciem pressões que vêm de fora, eles são capazes, por meio das mediações que operam por dentro, de realizar operações de afirmação étnica.

Ainda de acordo com o autor, a partir dos anos de 1960, a cultura popular urbana passou a ser envolvida pela indústria cultural vulgar, podendo então o popular ser compreendido, como vimos anteriormente, como o entrelaçamento de submissões e resistência. Para alguns sociólogos e antropólogos (Gutiérrez \& Romero apud MartínBarbero, 2013), tendo como base uma pesquisa sobre a cidade de Buenos Aires, essa produção de sentidos é construída nos movimentos sociais e nos bairros. A base da cultura política já não se faz somente no âmbito tradicional de organização dos trabalhadores, mas se dá também em espaços do bairro, como a escola, o café, as bibliotecas e os clubes - tudo isso tendo em vista as alterações no mundo do trabalho. Ainda, em consideração a essa reorganização social, os pesquisadores argentinos e o espanhol, radicado na Colômbia (Martín-Barbero, 2013, p. 273), consideraram que um elemento que tem corroborado com a constituição dessa cultura popular são os mediadores, que são os profissionais que atuam "nas instituições locais fazendo a conexão entre as experiências dos setores populares e outras experiências do mundo intelectual e das esquerdas".

\footnotetext{
${ }^{37}$ Os estudos de Barbero se dão principalmente em países da América Latina, a exemplo da Colômbia, país em que se radicou, cuja população indígena representa o principal segmento social destituído de direitos. No Brasil, reconhece-se que, para além dos índios, os negros devem também ser considerados, uma vez que representam um segmento historicamente excluído da distribuição de riquezas e do acesso a bens e serviços, além de que resistirem e lutarem contra a injustiça, a desigualdade social e preconceitos desde o período da escravidão. Para aprofundar sobre a constituição do povo brasileiro, indica-se: Sergio Buarque de Holanda, Gilberto Freire, Caio Prado Júnior e Darcy Ribeiro.
} 
Na perspectiva de Gramsci (2001), podemos compreender a mediação referida pelos pesquisadores como uma práxis pertinente aos intelectuais ${ }^{38}$ em colaboração ao processo de emancipação dos subalternos e denominado por ele de catarse: o momento em que os homens deixam a condição de egoístico-passional para elevarem-se ao éticopolítico, ao nível da consciência universal.

A Catarse deve ser entendida como a passagem da estrutura à superestrutura, da necessidade à liberdade, é o momento em que o individuo se transforma em ser social, no que se produz o sentido unitário da sociedade e se forma o bloco histórico que permite integrar dialeticamente as forças da esfera econômica com as expressões culturais e a participação das massas excluídas. (Semeraro, 1999, p. 156)

No bairro, ${ }^{39}$ desenvolve-se uma nova institucionalidade, um tecido social em que a vida cotidiana possibilita às pessoas a construção de um a gente, ${ }^{40}$ afinal, no trabalho elas são apenas o empregado. Aqui, elas se constituem e se transmitem, por meio de suas famílias, vizinhos e amigos. Dessa forma, de acordo com as reflexões de MartimBarbero (2013), a necessidade de $\operatorname{partidos}^{41}$ para a população de um modo em geral deixa de ser interessante em decorrência da dissociação da política à vida cotidiana, uma vez que os partidos se encontram mais interessados com a tomada do Estado ou com sua permanência no poder.

Alguns autores (Antunes, 1999; Carvalho \& Netto, 2000; Lessa, 2006), referindo-se à discussão lukacsiana na ontologia do ser social, afirmam que a vida cotidiana é caracterizada e característica de cada período e contexto histórico, sendo equivocado identificar o cotidiano como mero espaço de dominação e de alienação, como também de emancipação e de desalienação. Trata-se, no entanto, da primeira forma de consciência, sendo a consciência de classe adquirida na inter-relação entre o trabalho, a vida cotidiana e a consciência do ser social. Assim, o cotidiano é um campo

\footnotetext{
${ }^{38}$ Iamamoto (2003) afirma que o assistente social deve ser também considerado na sua condição de intelectual, devendo contribuir, como apontou Gramsci sobre o papel dos intelectuais orgânicos, na luta pela direção social e cultural dessas classes na sociedade.

${ }^{39}$ Optou-se por manter o bairro em menção à pesquisa realizada pelos pesquisadores argentinos citados no texto anteriormente, entretanto, entende-se que ela pode ocorrer nos espaços públicos em geral, nas comunidades, vilas, favelas, etc. Compreende-se que o bairro diz de um espaço comum partilhado e onde se encontram equipamentos públicos, a exemplo dos centros de saúde, centros de referencia de assistência social, creches e outros.

${ }^{40}$ Martín-Barbero (2013) utiliza essa expressão indicando que no bairro as pessoas compartilham questões comuns e, muitas vezes, esse compartilhamento colabora para a construção de uma identidade coletiva, o que possibilita inclusive a deflagração de lutas e conquistas de direitos.

${ }^{41}$ Em suas reflexões, Martín-Barbero (2013) aponta para uma questão presente na América Latina que diz respeito à representatividade dos partidos políticos e que de fato merece muitos estudos e reflexões. No entanto, entende-se que, em decorrência da forma como os Estados nacionais estão estruturados na América Latina, não é possível prescindir dos partidos políticos, o que não quer dizer deixar de ser críticos a eles.
} 
de construção histórica que está em disputa. Para Carvalho e Netto (2000, p. 67) é necessário considerar que o cotidiano tem características próprias, tais como:

i) a heterogeneidade que representa não só fenômenos e processos da natureza, como a linguagem, trabalho, interação, vida política, vida privada, mas também os interesses dos mais diversos, determinados por dinâmicas singulares e pela condição de classe. ii) imediaticidade. Corresponde às respostas imediatas, direta, sem mediações entre necessidade, pensamento e ação às carências singulares. iii) superficialidade extensiva, significando respostas ao conjunto de situações singulares, porém, sem considerar as relações que as vinculam.

Nesse sentido, na vida cotidiana desenvolve-se um nível de consciência individual e imediata, um senso comum que pode ser desenvolvido com vistas à reflexão do sujeito sobre as leis do mercado, o consumo, o uso do tempo, o corpo, o habitat, a consciência do possível para cada vida. Como afirma Yazbek (2003, p. 67), "os subalternos correspondem a uma realidade caracterizada pelo lugar que ocupam nas relações sociais", sendo que o mundo dos dominados não se encontra separado do mundo dos dominadores, afinal, possuem um ponto de contato, que se dá exatamente onde se exerce o domínio. Do ponto de vista cultural, são realidades que se interpenetram sem haver território definido.

No Brasil, a década de 1990 foi marcada pela ofensiva burguesa. Tratou-se da recomposição das forças políticas entre os setores conservadores, pressionados para melhor atender as novas exigências do capital internacional, bem como uma reação ao abalado sofrido pela crescente mobilização dos movimentos sociais que obtiveram importantes conquistas na Constituição Federal de 1988. O Plano Real, implementado pelo governo de Fernando Henrique Cardoso, ${ }^{42}$ no decorrer da década de 1990 foi o instrumento necessário para subordinar o país à ilusão da mundialização (Behring, 2003). O país conviveu com o desmantelamento do setor produtivo estatal, ${ }^{43}$ por meio

\footnotetext{
42 O Plano Real, iniciado em 1994 foi um plano econômico, desenvolvido e aplicado no Brasil durante o governo de Itamar Franco, quando Fernando Henrique Cardoso era o ministro da Fazenda, sendo eleito para a presidência da República posteriormente para dois mandatos. O principal objetivo era a redução e o controle da inflação, por meio de: i) redução de gastos públicos e aumento dos impostos como forma de controlar as contas do governo; ii) criação da Unidade Real de Valor (URV) como forma de desindexar a economia, até então indexada pelos índices de inflação; iii) criação de uma nova moeda forte: o real (R\$); iv) aumento das taxas de juros e aumentos dos compulsórios (dinheiro que os bancos devem recolher junto ao Banco Central). Estas medidas tinham como objetivo reduzir o consumo e provocar a queda da inflação; v) redução dos impostos de importação para aumentar a concorrência com os produtos nacionais, provocando a redução dos preços; vi) controle cambial, mantendo o Real valorizado diante ao Dólar. Esta medida visava estimular a importação e aumentar a concorrência interna, controlando o aumento dos preços dos produtos nacionais.

${ }^{43}$ De acordo com o artigo de Tiago Soares, na Carta Maior, em 21/10/2010, com base nos dados do livro de Aloysio Biondi, O Brasil privatizado, entre 1990 e 1999 foram privatizadas 166 empresas, com 546 mil postos de trabalho extintos diretamente. Disponível em:
} 
inclusive da privatização de setores estratégicos como telefonia e mineração, comprometendo outros setores de interesse social.

Ainda, de acordo com Nogueira (1998), a propaganda neoliberal elegeu temas da área social como responsáveis pelo déficit público e pelo excessivo gasto estatal, atribuindo ao setor público a condição de fonte única de corrupção e ineficiência. Há uma redução da crise ao problema do déficit público, ao "gigantismo" do Estado, banalizando a ideia clássica de que este deveria estar sob o controle da sociedade. Partiu-se então para a desvalorização do conjunto das instituições e das ações públicas junto à sociedade, sempre em nome da necessidade que todos teriam de se verem livres do Estado. Ao explorar um sentimento nascente de desconfiança e cansaço na sociedade diante de tudo o que era estatal, o neoliberalismo brasileiro encontrou meios de se reproduzir num país de contrastes profundos, repleto de problemas complexos, imerso em uma grave crise ética, no qual o futuro se tornava incerto. A generalização de um desencantamento utópico trouxe para o imaginário social que a política estava posta em xeque, reduzida à corrupção, aos interesses privados. Estavam dados os efeitos desagregadores da mundialização sobre a política: a transferência desta para o mercado.

Ao final dos anos de 1990, setores organizados da sociedade persistiram em estado de mobilização precária, sendo alguns deles esvaziados em função do desemprego estrutural e do complexo processo de despolitização. A sociedade foi engolida pelo pragmatismo da disputa eleitoral e pelo uso recorrente de estratégias de marketing e de dissimulações. Alguns partidos de esquerda à época, a exemplo do Partido dos Trabalhadores (PT), fizeram concessões de seus programas originais para compor grandes coligações, assegurando duas vitórias a Luiz Inácio Lula da Silva ${ }^{44}$ à Presidência da República, bem como a eleição de sua candidata, Dilma Rousseff, para o período de 2011 a 2014 e 2015 a 2018. O período Lula/Dilma tem sido compreendido a partir de diferentes análises. Algumas têm apontado para um período constituído por um novo desenvolvimentismo ou neodesenvolvimentismo ou social-desenvolvimentista e outras indicam se tratar de um neoliberalismo à brasileira. ${ }^{45}$ Esse assunto de grande

<http://www.cartamaior.com.br/?/Editoria/Economia/Memoria-de-um-Brasil-privatizado/7/16016>. Acesso em: 11 jan. 2016.

${ }^{44}$ Luiz Inácio Lula da Silva foi candidato pelo Partido dos Trabalhados e após três tentativas frustradas conseguiu se eleger presidente em 2002. Ex-líder sindical nos anos 1970/1980, foi cofundador da Central Única dos Trabalhadores (CUT) e do Partido dos Trabalhadores (PT). Por sua atuação política no campo sindical tornou-se uma referencia para a questão social e para os trabalhadores em geral.

${ }^{45}$ Esse conceito foi desenvolvido na tese defendida por Renato Francisco dos Santos Paula, orientado pela Prof. ${ }^{a}$ Dr. ${ }^{a}$ Maria Carmelita Yazbek, em julho de 2013, no Programa de Pós-Graduação em Serviço Social da Pontifícia Universidade Católica de São Paulo (PUC-SP). A tese analisa o projeto neoliberal e o 
complexidade tem merecido a atenção de analistas experientes, sendo importante suscitá-lo haja vista a sua importância para a análise do tema desenvolvido nesta tese, sem a pretensão de esgotá-lo, mas situando sobre as correntes e significados em debate na contemporaneidade.

De acordo com Castelo (2012, p. 629) existem três correntes de pensamento filiadas à ideia do novo desenvolvimentismo no país. A primeira pode ser chamada de macroeconomia estruturalista do desenvolvimentismo e tem como expoente principal Bresser Pereira. ${ }^{46} \mathrm{O}$ centro dessa concepção afirma a "primazia do mercado e seus mecanismos de produção da riqueza, com uma atuação reguladora do Estado nas falhas de mercado, especialmente nas políticas cambiais e de juros, com destaque para a promoção das exportações". A segunda corrente, chamada de pós-keynesiana, constituída por intelectuais tradicionais alinhados ao estruturalismo cepalino e ao keynesianismo, ${ }^{47}$ assemelha-se muito à primeira e sustenta o papel do Estado como redutor das incertezas do mercado. Tal corrente aponta para uma "coalizão nacional entre burguesia industrial nacional, burocracia estatal, setores médios e trabalhadores, com hegemonia dos primeiros dois grupos sobre os demais" (Castelo, 2012, p. 629). A terceira corrente, denominada de social-desenvolvimentista, é defendida por um grupo

suposto projeto (neo)desenvolvimentista vigentes no Brasil dos últimos 25 anos, concluindo que o ciclo atual de desenvolvimento carrega as características estruturais do período anterior, bem como renova parte das estratégias liberais a partir de adaptações "sociais" e "culturais" próprias da realidade local, o que permitiu ao autor afirmar a existência de um neoliberalismo à brasileira. Essa expressão foi apropriada a partir da leitura de autores como Reinaldo Gonçalves, Lucio Flavio de Almeida, Armando Boito Júnior, entre outros que a usam informalmente quase que como senso comum, sem aprofundamentos. A partir da Lei geral da acumulação, crédito e capital fictício no Livro III d’O Capital (Marx) e das reflexões de Mandel e Mészáros o autor demonstra como se realiza a expansão do capital na contemporaneidade e como se realizam as crises no contexto neoliberal. Com base nessa reflexão mais geral, Paula (2013) aborda as particularidades brasileiras na constituição do capitalismo brasileiro a partir de autores como Florestan Fernandes, Caio Prado Júnior, Nelson Werneck, dentre outros. No período atual, concentra-se sobre as particularidades brasileiras atuais se referenciando em autores de matizes teóricas diferenciadas, mas que contribuíram para a compreensão do que ele convencionou denominar neoliberalismo à brasileira, demonstrando como o neoliberalismo no Brasil foi diferente do resto do mundo. Os autores são: Sergio L. Lazzarinni, Lucio Flavio Rodrigues de Almeida, Armando Boito Júnior, Valério Arcary e André Singer. É importante ainda registrar que estudos sobre a especificidade do capitalismo brasileiro estão presentes em autores como Francisco de Oliveira, que analisa o governo Lula, que, embora tenha sua identidade no campo do trabalho, passou a representar os interesses da classe dominante sem pertencer a ela, sendo esse um traço muito particular do capitalismo brasileiro ou do neoliberalismo à brasileira.

${ }^{46}$ Luiz Carlos Bresser-Pereira é economista, cientista político, administrador de empresas e formado em direito. Foi ministro da Fazenda no governo de José Sarney, no ano de 1987.

47 As formulações metodológicas dessa corrente podem ser encontradas no livro organizado por João Sicsú, Luiz Fernando Paula e Michel Renault, intitulado Novo Desenvolvimentismo: Um Projeto Nacional de Crescimento com Equidade Social (Barueri: Manole, Rio de Janeiro: Fundação Konrad Adenauer, 2005). 
de intelectuais ligados ao $\mathrm{PT}^{48}$ que acreditam que uma inflexão nas políticas econômicas, sociais e externa no Brasil teria levado o país a romper com o neoliberalismo e a viver uma época pós-neoliberal, colaborando para uma grande transformação e/ou a emergência de um padrão de acumulação. As propostas desse modelo se assentam na afirmação do mercado interno por meio da ampliação do consumo de massa, tendo o Estado uma importância maior em comparação com as demais correntes, sendo que as políticas macroeconômicas devem ser subordinadas às de desenvolvimento.

A perspectiva que considera esse período se tratar do neoliberalismo à brasileira argumenta que, mesmo tendo ocorrido inflexões políticas, institucionais, partidárias, ideológicas, culturais e econômicas no governo Lula, não houve a reprodução do trinômio clássico do desenvolvimentismo - industrialização, intervencionismo e nacionalismo, ${ }^{49}$ sendo que ao se manter o essencial, ou seja, ao não ter alterado o estruturante e o estrutural, o neoliberalismo acaba por transformar qualquer mudança em beneficio de si e do capitalismo. Para Paula (2013, p. 265), tudo converge a fortalecer as estratégias no capital nesse estágio. Portanto,

Sem mexer no núcleo, as mudanças na membrana tendem a reforçar este núcleo ainda que possa rearranjar o lugar e o espaço de algumas células em seu interior. E, isto no Brasil tem sido feito de um modo engenhosamente peculiar. Em outros termos, por mais que os momentos de síntese histórica do desenvolvimentismo brasileiro possam distinguir-se entre si por particularidades conjunturais ou mesmo por medidas sui generis que possa torná-los único no trajeto histórico, a estrutura essencial das medidas permanecem, e, assim, favorecem a perenização da lógica do desenvolvimento capitalista e do conceito conservador de desenvolvimentismo.

\footnotetext{
${ }^{48}$ Em 2010, Aloizio Mercadante Oliva defendeu uma tese de doutorado, que teve, dentre os seus arguidores, Bresser Pereira e Delfim Netto, na qual sistematizou o pensamento dessa terceira corrente. As Bases do Novo Desenvolvimentismo no Brasil: Análise do Governo Lula (2003-2010) foi o nome que a tese recebeu, sendo apresentada ao Instituto de Economia da Universidade de Campinas (Unicamp). Castelo (2012) identifica também a produção de Marcio Pochmann, quando este esteve à frente do Ipea como seu presidente, de 2007 a 2012 e Emir Sader como organizador do livro Lula e Dilma: 10 anos de governos pós-neoliberais no Brasil (2013).

${ }^{49}$ De acordo com Filgueiras \& Oliveira (2013, apud Paula, 2013, p. 283) "apesar da melhora em todos os indicadores conjunturais no governo Lula não se identifica uma mudança estrutural pró-indústria de maior valor agregado, nem uma inserção externa mais sólida com superávits provenientes de manufaturas de alta tecnologia. Pelo contrário, o BNDES está atuando a favor da produção de produtos primários e da indústria intensiva em recursos naturais e em energia. Seu programa de estímulo a internacionalização das “campeãs brasileiras" não faz parte de um planejamento estatal de desenvolvimento econômico, mas, sim, atende à demanda a burguesia interna por financiamentos para a sua expansão devido às oportunidades de lucros surgidas no exterior. O que se percebe é um processo de desindustrialização que no médio ou longo prazo possa se tornar extremamente complexo e custoso se reverter".
} 
Paula (2013, p. 254) corrobora ainda com a ideia de que o neoliberalismo no Brasil foi instituído em duas fases: a primeira foi a contrarreforma ${ }^{50}$ do Estado, executando as diretrizes do Consenso de Washington sob a primazia do projeto de estabilização monetária, o Plano Real. A segunda é caracterizada por experimentalismos relativamente bem-sucedidos, dado que o impacto do efeito do ajuste já havia passado, tendo início no novo século até os dias atuais. Ambas as fases se dão no contexto de uma agenda que mantém a ortodoxia neoliberal que, ao ser flexibilizada, pode levar à uma errônea impressão de que se trata de programas diferenciados. "A supremacia do processo de financeirização pode nos levar a essa falsa identificação da realidade, se não nos dermos conta da permanência dos níveis crescentes de expropriação do trabalho, da terra, dos direitos, etc." Para Paula (2013) o que ocorreu entre o período FHC e a era Lula/Dilma, que ele denomina de Sistema de Reciprocidades, foi um deslocamento não traumático do capital financeiro internacional e da burguesia brasileira a ele vinculada. Essa alteração ascendeu, não significando a supressão ou a marginalização da outra fração. Os membros da burguesia interna que ainda não haviam se "internacionalizado" e pouco se "financeirizado" passaram a se "internacionalizar" e a se "financeirizar". Ou seja, os membros da classe proprietária que não estavam no centro do poder na era FHC foram "incorporados" nesse período ao Sistema de Reciprocidades existente entre os principais agentes da acumulação, que são: o Estado, o capital produtivo nacional e internacional (em escala menor), o capital financeiro internacional (em escala dominante) e as empresas com base na acumulação "primitiva" em território nacional.

É por meio do Sistema de Reciprocidades que se tem articulado um intenso metabolismo entre capitais, mantendo a produção territorializada, mas necessitando da desterritorialização para sua reprodução. Essa fase de alteração da dinâmica interclasses promoveu a emergência de estratos da classe trabalhadora nas estruturas do poder político e na estrutura do Estado que, consequentemente, criaram medidas que induziram à ampliação do mercado consumidor e elevaram estes novos consumidores ao que se convencionou como a nova classe média. Esse movimento deu origem também a um aspecto do neoliberalismo à brasileira destacado por Paula (2013), que diz respeito à diferenciação no trato da questão social praticado na primeira fase de

\footnotetext{
${ }^{50}$ A contrarreforma, para Behring (2003), tem relação com a reforma do Estado imprimida no governo de Fernando Henrique Cardoso (FHC) e tem um sentido totalmente ideológico. Para ela, trata-se de uma "contra-reforma" do Estado, pois o discurso do programa de reforma se fundamenta apenas em elementos fiscais. A proteção social aparece mais como embasamento legal aos planos e emendas constitucionais para deixá-la mais aceitável socialmente.
} 
implantação do neoliberalismo no Brasil, caracterizada por ações focalizadas e articuladas à filantropia. Essa diferenciação se trata de uma ruptura com a minimização do Estado no que tange às suas responsabilidades com a reprodução da classe trabalhadora. Um novo modelo de proteção social foi adotado com ênfase nos programas de transferência de renda, de qualificação e de uma política de acesso a bens e serviços públicos. Essa estratégia requereu uma alteração na estrutura física e financeira da máquina estatal, uma vez que no padrão neoliberal ela é direcionada para as funções de administração geral, da segurança e da justiça. Paula (2013) afirma que nesse processo há uma relação de atração e repulsa entre a primeira e a segunda fase do neoliberalismo no Brasil. Repulsa quando se aponta para um maior gasto social federal e atração por esse investimento público funcionar como um vetor anticíclico ao promover o desenvolvimento regional e no setor privado. Portanto, essa conjuntura, constituída pelo período mais longo de democracia da história do país tem indicado que a democracia no Estado brasileiro tem relação direta com os arranjos políticos da classe dominante que, sob o amalgama do pensamento liberal, assume a forma de democracia liberal de massa com um objetivo central: a sustentabilidade que esse tipo de Estado possibilita ao próprio capitalismo.

Amparado pelos estatutos normativos dispostos na Constituição Federal de 1988, alcunhada de Constituição Cidadã, a democracia liberal tanto consagra o direito à vida quanto à propriedade, dá ao Estado o direito de exercer o poder coercitivo, mas também direito à participação dos cidadãos na agenda pública. Demonstra, portanto, que o Estado, longe de ser um bloco monolítico, como apontou Gramsci (2001), ${ }^{51}$ é a expressão das forças em presença na sociedade civil em disputa por hegemonia, sendo essa relação dinâmica, por envolver vários sujeitos políticos coletivos.

A era Lula/Dilma, em que pese não ter promovido uma ruptura com a política econômica implementada por FHC, tem abordado de forma diferenciada a questão social e o enfrentamento a pobreza em comparação a outros períodos históricos no Brasil, como indica Yasbek (2012), entendendo inclusive que "estaríamos diante de uma nova roupagem do neoliberalismo, pois seus acessórios o particularizam, o que

\footnotetext{
${ }^{51}$ Para Gramsci (2001), sobretudo a partir de 1870, havia surgido uma nova esfera do ser social capitalista: o mundo das auto-organizações. São os partidos de massa, os sindicatos, as diversas associações, os movimentos sociais, dentre outros. Na verdade, tudo que resultava na presença, na esfera pública, de novos sujeitos individuais e coletivos. Essa nova esfera, Gramsci conceituou como sociedade civil e a considerou como integrante do Estado, em sentido amplo. O Estado é constituído por um "núcleo duro" de poder, resultante da disputa por hegemonia travado no cenário das lutas de classes. O efetivo exercício do poder governamental se dá por meio da busca do consenso e da legitimação, devendo o Estado considerar os diversos interesses que não os restritos à classe dominante.
} 
também nos permite falar em um neoliberalismo à brasileira, desafinando um pouco o coro do novo desenvolvimentismo" (Paula, 2013, p. 255).

Importa, por fim, à compreensão das categorias de análise aqui expostas, resgatar o entendimento de que o Estado é produto histórico do modo capitalista de produção e embora a forma como ele se desenvolve diga respeito a uma universalidade comum aos Estados latino-americanos, a realidade só pode ser compreendida após o entendimento de suas singularidades e particularidades. Desse modo, deve-se considerar ainda, como particularidade brasileira, a singularidade da liderança do ex-presidente Lula, com enorme adesão popular junto à classe subalterna, dando a estes a oportunidade de sentirem em condições (mais ideais que reais) de fazer parte do poder político da nação, originando o que Antunes (2015) denominou de lulismo. ${ }^{52}$

Nessa perspectiva, na era Lula/Dilma, o investimento na política Assistência Social torna-se relevante e emblemático, visto que nos governos neoliberais os investimentos em ações assistenciais objetivam atenuar o apartamento social da classe trabalhadora, dando a impressão de ampliação de acessos, sempre de forma muito focalizada. Em 2004, o Sistema Único de Assistência Social (Suas) foi criado, configurando-se como um avanço político e social, pois, até esse período, o único tratamento dado após a Constituição Federal de 1988, por parte dos governos brasileiros, à Assistência Social foi a criação da Lei Orgânica de Assistência Social (Loas), em 1993, quase no final do governo de Itamar Franco, que regulamentou os capítulos da CF-88 para a área. A Loas, em que pese a sua importância histórica, apontava uma direção, mas nenhuma orientação quanto ao reordenamento e a operacionalização da política.

\footnotetext{
52 O fenômeno do Lulismo foi tratado primeiramente por André Singer em 2009, por meio do artigo "Raízes sociais e ideológicas do lulismo" publicado pela revista Novos Estudos, do Centro Brasileiro e Planejamento (Cebrap), tendo publicado, em 2012, "Os sentidos do Lulismo - Reforma gradual e pacto conservador" pela Companhia das Letras. Ricardo Antunes também tem corroborado sobre esse fenômeno e em entrevista ao Correio da Cidadania em 09/11/2015, aponta que o fenômeno do lulismo é muito recente, sendo pouco conhecido, embora se possa ter muitas pistas, como vem se dando desde 2002 pelo menos. Trata-se de uma figura carismática que, no apogeu, conseguia atingir as duas pontas da classe trabalhadora. "No apogeu do Lula, ele tinha um respaldo quase inquebrantável da classe trabalhadora organizada brasileira, aquela classe trabalhadora que tem formas de associação sindical ou de algum outro nível, onde Lula era sua principal liderança. Não sem razão. É preciso dizer que Lula foi, talvez, a maior liderança sindical do século 20 brasileiro. É passado, mas foi. E foi com base nessa trajetória, de 1975 até 1989, e depois até 2002, algo real, que ele se tornou uma liderança nacional. O lulismo, e em particular seu personagem, está também atado de forma indissolúvel à figura do Lula - assim como o varguismo está atado a Vargas e o brizolismo à figura do Brizola. Mas o lulismo não tem herdeiros". Cf.: A Desertificação Neoliberal do Brasil e A Esquerda Fora do Lugar. Entrevista disponível em: $<$ http://www.correiocidadania.com.br/index.php?option=com_content $\&$ view $=$ article $\&$ id $=11210: 2015$ 11-09-21-35-07\&catid=34:manchete>. Acesso em 27 nov. 2015.
} 
A criação e a implantação do Suas tem se dado em um período adverso aos interesses da classe trabalhadora, mas, contraditoriamente - e porque não até por isso -, inaugura para a Assistência Social um novo momento até então sem referência no país, exigindo um olhar dialético sobre a trajetória histórica dessa política, com vistas a revelar as concepções das forças políticas em presença no que tange, especialmente, a questão do direito do usuário dessa política à Comunicação Pública. Como afirmou Couto (2004), é por meio da análise do cotidiano que se pode apreender sobre os fenômenos, e, assim, revelar as transformações que puderam ser feitas com a implantação do Suas e quais ações têm contribuído para referendar as velhas formas de se relacionar com a população. 


\section{CAPÍTULO 3}

\section{Assistência social: uma política em movimento}

Embora a era Lula/Dilma tenha reconhecido de forma diferenciada a questão social, desencadeando o enfretamento à pobreza no país, sob uma nova abordagem, como analisa Yasbek (2012), alguns autores advertem, a exemplo de Pereira (2012, p. 730), que as mudanças verificadas na política social brasileira "não ocorrem de forma isolada, unilateral e autônoma, uma vez que elas fazem parte do processo mundial de reestruturação capitalista, iniciado no final dos anos 1970, cuja justificação ideológica encontra guarida no credo neoliberal desde então dominante". No entanto, em que pese ser considerado que em todas as políticas sociais prevalecem fenômenos ${ }^{53}$ com esses princípios, Pereira (2012, p. 751) considera que essas tendências não são fatais e que tudo depende do regime político vigente, da organização do movimento social, da correlação de forças em presença e do sentido de desenvolvimento que se pretende alcançar, uma vez que:

a política social por ser um processo complexo e internamente contraditório e não um sistema, um ato formal de Estado ou de governo, uma receita técnica ou mera resposta institucional —, ela pode mudar de tendência e ser colocada a serviço do trabalho na sua luta endêmica contra o capital.

É, portanto, no rastro da dinâmica societária, contradizendo a orientação hegemônica, que a Assistência Social no Brasil se instituiu como uma política pública,

\footnotetext{
${ }^{53}$ Os fenômenos identificados por Pereira (2012) como relacionados ao neoliberalismo nas políticas sociais são: a) a direitização da política social. Isso significa que a própria política social não está vinculada a um compromisso social, mas aos princípios que norteiam o neoliberalismo, ou seja, reduzir o pauperismo realizando ações focalizadas e assegurando os mínimos sociais; b) a monetarização da política social. A autora destaca que as ações de repasse de dinheiro aos pobres os transformam em consumidores portadores de cartão de crédito ou compradores de produtos a prazo e, portanto, permanentemente endividados. Essa monetarização termina por não garantir-lhes, como dever de cidadania, serviços sociais públicos, empregos e salários de qualidade; c) a laborização precária da política social, visto que a principal responsabilidade desta, principalmente da Assistência Social, é o encaminhamento para o trabalho. Como tal encaminhamento é limitado, sem haver condições de inserir a todos no mercado formal, os governos apelam para ações empreendedoristas e de baixo custo e nível; d) a descidadanização da política social. Trata-se da autorresponsabilização dos pobres pelo seu próprio sustento e bem-estar dissociada da cidadania. Ou seja, o trabalho assegurado no mercado formal é precarizado, flexível, mal pago e desprotegido e o que vem sendo chamado de assistência ocorre sob os moldes do que acontecia no século XIX sob a regência do sistema das workhouses inglesas; e) o estado de emergência econômica. Trata-se do expediente utilizado pelos governos para agirem livremente tratando a questão social como se fosse uma exceção e um perigo que levaria o país a um precipício. Sobre o governo Lula, a autora destaca, utilizando-se do conceito de Francisco de Oliveira de "hegemonia às avessas", que significa o exercício da liderança material (exploração) pela classe burguesa, sob o consentimento das classes dominadas que acreditaram exercer a liderança moral e intelectual, invertendo, assim, o conceito de hegemonia gramsciana. Nesse sentido, há uma dissociação da política social dos direitos de cidadania, uma vez que direitos não combinam com estados de exceção.
} 
integrando a Seguridade Social em conjunto com a Previdência e a Saúde, a partir da Constituição Federal de 1988 (CF-88). Por política pública, de acordo com Pereira (1996, p. 130) compreende-se "a ação coletiva que concretiza direitos sociais declarados e garantidos em lei. É mediante as políticas públicas que são distribuídos ou redistribuídos bens e serviços sociais, em resposta às demandas da sociedade", sendo de competência do Estado a sua execução.

Em princípios gerais, a Seguridade Social associa, ao mesmo tempo, universalidade e seletividade, centralização e descentralização, distributividade e redistributividade, gratuidade e contributividade. Ou seja, a Saúde é constituída pelos princípios da universalidade, gratuidade, não contributividade, redistribuitividade e descentralização, constituindo-se em um direito universal de acesso a qualquer cidadão aos serviços convencionados como assistência à saúde. A Previdência é caracterizada como contributiva, uma vez que só tem acesso aos benefícios e aos serviços aqueles que contribuem financeiramente. Portanto, trata-se de uma política seletiva, não redistributiva e centralizada.

À Assistência Social, regulada em 1993 por meio da Lei Orgânica de Assistência Social (Loas), foi imprimido um caráter de seletividade por definir critérios de atendimento, mas também de universalidade e de gratuidade no acesso dos benefícios e dos serviços; não contributividade no que tange a natureza dos direitos; redistributividade no que se refere aos mecanismos de financiamento; e descentralização e participação dado a sua forma de organização político-institucional. De acordo com Boschetti (2003), a Loas significou o fim da travessia do deserto, uma vez que a trajetória da assistência social se deu em um campo nebuloso, permeado pela compreensão da assistência social como dever moral e como uma solidariedade, sujeita a possibilidades pessoais e políticas, sendo um expoente expressivo dessa trajetória a atuação das primeiras damas, ${ }^{54}$ as ações religiosas e a filantropia.

O reconhecimento tardio da Assistência Social como política pública atribui-se à noção de desenvolvimento do capitalismo no Brasil e à forma como se originou o Estado brasileiro. Segundo Behring (2003), a incapacidade do país em romper com uma

\footnotetext{
${ }^{54}$ Refere-se à participação das primeiras-damas na máquina pública das esposas dos políticos eleitos. A estas, cabia o papel de ouvir as demandas sociais da população e intermediar junto ao marido a assistência necessária, mas triada por ela. Essa participação da primeira-dama na política, como extensão do marido na gestão pública, gerava um círculo vicioso de dependências políticas e econômicas, denominado de apadrinhamento que se trata de uma característica do clientelismo. Sobre esse tema sugere-se o livro de Iraildes Caldas Torres, As primeiras damas e a Assistência Social - relações de gênero e poder (São Paulo: Editora Cortez, 2002).
} 
relação dependente com o exterior, de desagregar completamente os setores arcaicos e, ainda, de superar o subdesenvolvimento gerado pela concentração da riqueza, propiciou um Estado com ambiguidades entre um liberalismo formal e a garantia de privilégios, além de este desempenhar um papel, pela lógica liberal, da iniciativa privada.

A CF-88, ao estabelecer a Assistência Social na qualidade de política pública, reconhece que os pobres não o são por uma questão meritocrática, mas que se encontram nessa situação em decorrência da dinâmica societária inscrita no capitalismo, sendo da competência do Estado a mediação entre o conflito capital e trabalho, manifesto pelas expressões da questão social. Draibe (2003) aponta que a CF-88 consagrou novos princípios de reestruturação do sistema de políticas sociais, pautados no direito social como fundamento da política; no compromisso da primazia do Estado, tendo o setor privado um papel complementar; na concepção da seguridade social na perspectiva de proteção, e não apenas na ideia de seguro e, no plano organizacional, a descentralização e a participação social como diretrizes para o reordenamento institucional do sistema.

Nos anos de 1990, a adoção do neoliberalismo como modelo político, econômico e social no país comprometeu a implementação da política de Assistência Social em decorrência do ajuste fiscal proposto pelos sucessivos governos. ${ }^{55}$ Ao longo de onze anos, o movimento social de luta pelo reconhecimento da Assistência Social como política pública se manteve organizado, reivindicando, nos espaços do Conselho

\footnotetext{
${ }^{55}$ O Brasil, a meio caminho de tentar criar um Estado de Bem-estar Social, foi tomado pelo ajuste neoliberal, havendo uma articulação entre assistencialismo focalizado e mercado livre. Houve o incentivo à privatização da previdência e da saúde e à ampliação dos programas sociais. As expressões da questão social foram atendidas por meio de políticas focalizadas, seletivas e compensatórias, afastando-se do conceito constitucional de seguridade e da Loas. Em 1995, foi criado o Programa Comunidade Solidária, pelo governo de Fernando Henrique Cardoso (FHC), por meio do Decreto no 1.366, de 12 de janeiro. Esse programa esteve vinculado diretamente à Casa Civil e foi presidido pela então primeira-dama do país, Ruth Cardoso, sendo encerrado em dezembro de 2002.

A política de assistência social na era FHC foi conduzida pelo Programa Comunidade Solidária e pelo Ministério da Previdência e Assistência Social (MPAS). Destacam-se, como ações do Comunidade Solidária, as campanhas de combate à fome e incentivo à participação da sociedade em ações solidárias, a exemplo da doação de alimentos não perecíveis em eventos culturais, trabalho social voluntário (Lei do Voluntariado) e estimulo à criação de organizações não governamentais (ONGs). A atuação do MPAS teve ações focalizadas, pautadas muitas vezes pela agenda internacional, a exemplo do trabalho infantil (Programa de Erradicação do Trabalho Infantil/Peti), do abuso e da exploração de crianças (Programa Sentinela) e de combate à evasão escolar no ensino fundamental e médio e prevenção ao uso de drogas (Programa Agente Jovem). Importa registrar que, durante a era FHC, todas as conferências nacionais de assistência social criticaram duramente o Programa Comunidade Solidária, sendo que a conferência realizada em 1997 aprovou a sua extinção. Dados indicam que mesmo programas como o Peti, que obteve crescimento considerável, não atingiu, no ano de 2002, 30,5\% do universo possível (Boschetti, 2003 e Behring, 2003). Draibe (2003), em seu estudo sobre A política social na era FHC e o sistema de proteção social, afirma que os programas de transferência monetária às famílias pobres, ocorridos ao final do segundo mandato, foram um desvio do projeto original do governo e uma mudança no sistema tradicional de proteção advindos das condições sociais do período e da pressão popular.
} 
Nacional de Assistência Social (CNAS) e nas Conferências nacional de Assistência Social ocorridas nos anos de 1990, a implantação da Loas e a criação de um sistema único descentralizado e participativo da Assistência Social, o Suas.

Em 2003, a IV Conferência Nacional deliberou pela elaboração e pela implementação do Suas, sendo deflagrado um amplo processo de discussão com base em uma versão preliminar apresentado pelo CNAS. ${ }^{56}$ Após esse processo de debates, foi aprovado na plenária do conselho a Resolução $\mathrm{n}^{\circ} 145$, publicada no Diário Oficial da União em 28 de outubro de 2004, estabelecendo as diretrizes da Política Nacional de Assistência Social (PNAS/2004) e a criação do Suas.

\subsection{Sistema Único de Assistência Social: estrutura e organização}

A criação do Suas, apontada como a primeira etapa pela diretora de gestão do Suas/MDS, Simone Albuquerque, à época da entrevista decorrente da pesquisa exploratória, "cuidou das normativas de regulação e funcionamento, das normas para a área de recursos humanos e do desenho do financiamento, sendo que a segunda etapa, cuidou da construção da rede estatal". A esse respeito, importa o registro feito ao observar que todas as Resoluções sobre o Suas são deliberadas e aprovadas nas instâncias do $\mathrm{CNAS}^{57}$ e publicadas posteriormente no Diário Oficial da União. Desde a Loas de 1993, a Assistência Social tem acumulado uma dinâmica de participação social com a instituição dos conselhos deliberativos no âmbito municipal, estadual e federal, além das conferências que são realizadas a cada dois anos, convocadas e coordenadas pelos conselhos em cada esfera da federação. Esse nível de organização, além de ter possibilitado o movimento de luta pela Assistência Social como política pública, permitiu também a criação de uma organização com instâncias para debates, deliberações e pactos entre os entes federados. Portanto, o Suas se movimenta a partir dessas instâncias, sendo o CNAS o nível máximo de deliberação da política.

\footnotetext{
${ }^{56}$ Esse processo contou com a participação dos conselhos estaduais e municipais de Assistência Social, Fórum Nacional de Secretários de Assistência Social (Fonseas), colegiado de gestores nacionais, estaduais e municipais de assistência social, associações de municípios, fóruns estaduais, regionais governamentais e não governamentais, bem como universidades e núcleos de estudos, entidades de assistência social, categorias profissionais, dentre outros.

57 Agrega-se a essa informação que os encaminhamentos no CNAS derivam das deliberações das conferências nacionais, estaduais e municipais realizadas ao longo do período de criação do Suas. Desde 2005, foram realizadas, de dois em dois anos, sete conferências nacionais. A X Conferência Nacional de Assistência Social, realizada em Brasília (DF), em dezembro de 2015, teve como tema: Pacto Republicano no Suas rumo a 2026: o Suas que temos e que queremos.
} 
Há, portanto, uma estrutura organizacional que se realiza em todos os níveis de gestão. Todo órgão executivo da Assistência Social dever ter ligado diretamente a si: o conselho de Assistência Social paritário, constituído por membros do governo e da sociedade civil para deliberar sobre a política; uma instância de pactuação da política constituída pelos órgãos executivos da área e o fundo de financiamento da Assistência Social. No nível federal, o Suas é gerenciado da seguinte forma: o órgão gestor da política de Assistência Social é o Ministério de Desenvolvimento Social e Combate a Fome (MDS), que está vinculado diretamente ao CNAS, que delibera sobre a política a ser seguida. A instância de negociação e pactuação é denominada de CIT (Comissão Intergestora Tripartite), constituída por representantes de gestores federal, estaduais e municipais, cujo objetivo é viabilizar a política quanto aos aspectos operacionais da gestão do Suas. O recurso financeiro da Assistência Social é alocado no Fundo Nacional de Assistência Social (FNAS), sendo o repasse dos recursos para estados e municípios ocorrendo de fundo a fundo.

\section{Figura 1}

\section{Estrutura organizacional da política de Assistência Social no âmbito federal}

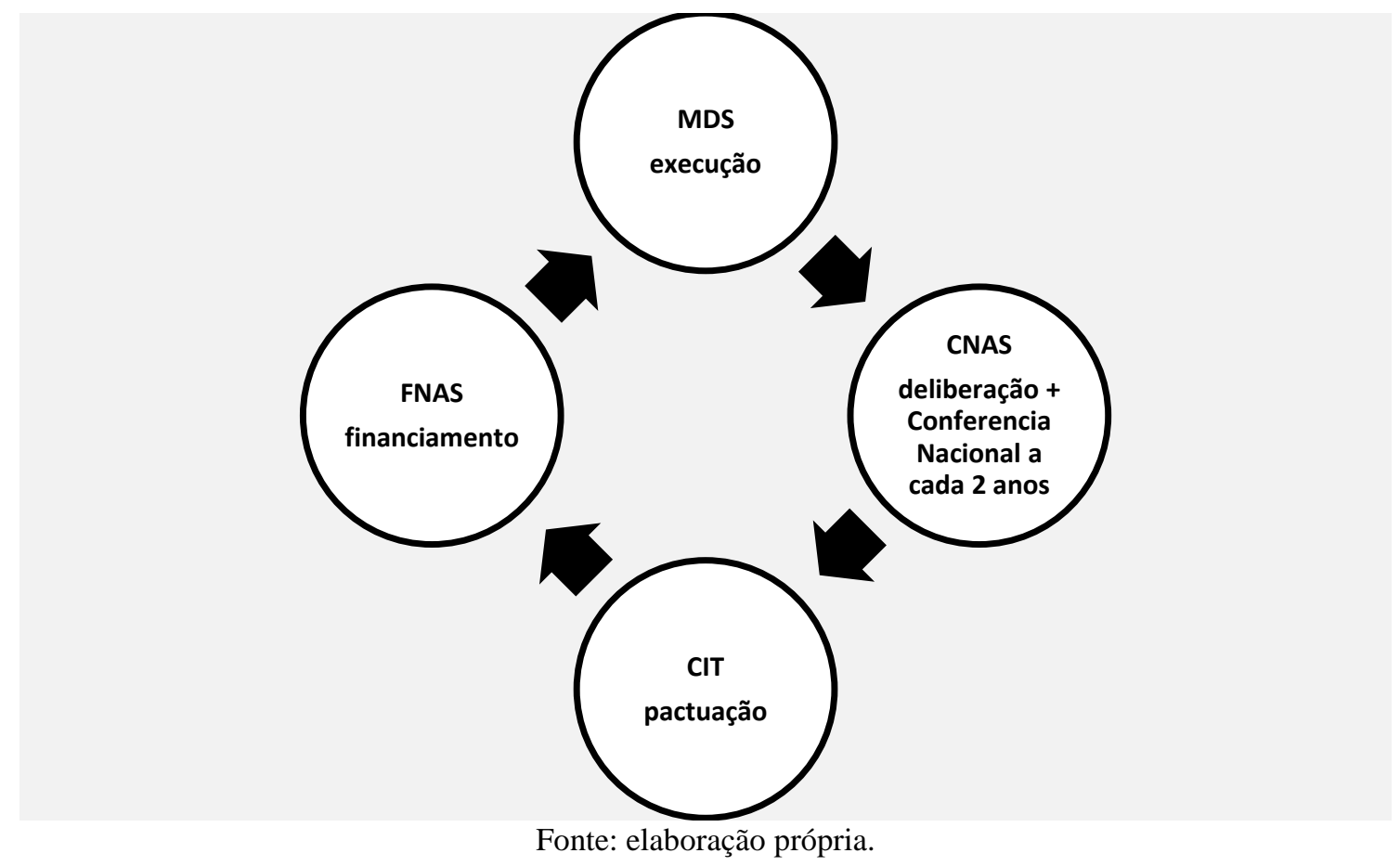

Nos estados da federação, a instância da política para pactuar procedimentos de gestão, de distribuição e de partilha de recursos estaduais e federais é denominada de 
CIB (Comissão Intergestores Bipartite). É constituída por três representantes dos estados, que, por sua vez, são indicados pelo gestor estadual da Assistência Social e por seis gestores municipais, indicados pelo Colegiado Estadual de Gestores Municipais de Assistência Social, respeitando a representação regional e o porte dos municípios de acordo com a PNAS. Ao órgão gestor está vinculado o Conselho Estadual de Assistência Social (Ceas), assim como os recursos alocados no Fundo Estadual de Assistência Social.

\section{Figura 2}

\section{Estrutura organizacional da política de Assistência Social no âmbito estadual}

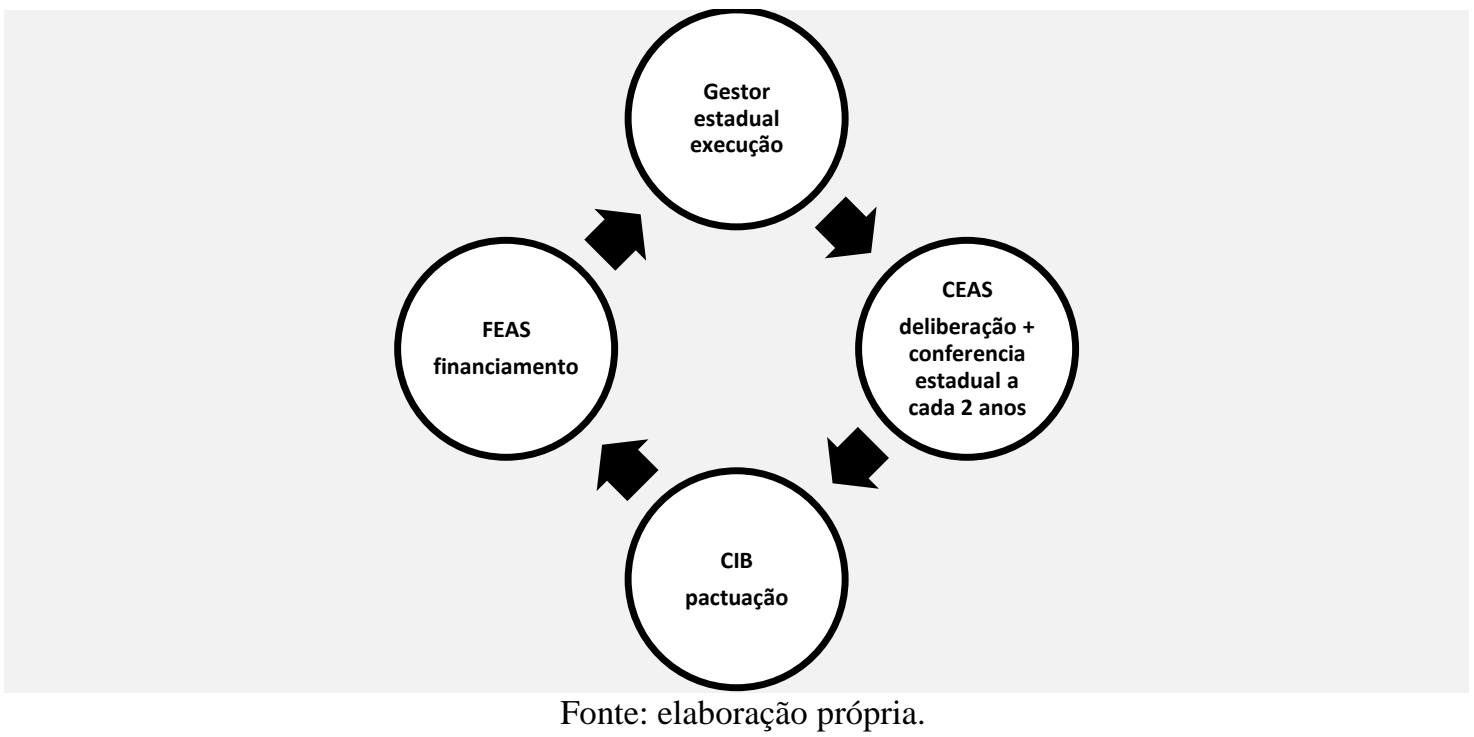

Nos municípios, o órgão executivo está vinculado ao Conselho Municipal de Assistência Social (CMAS) e todos devem ter o Fundo Municipal de Assistência Social gerenciado e fiscalizado pelo conselho, conforme podemos verificar na figura abaixo. De acordo com o Censo Suas/2014, 5.507 municípios possuem um conselho municipal de Assistência Social, sendo o controle social do Programa Bolsa Família realizado por 4.748 deles. 


\section{Figura 3}

\section{Estrutura organizacional da política de Assistência Social no âmbito municipal}

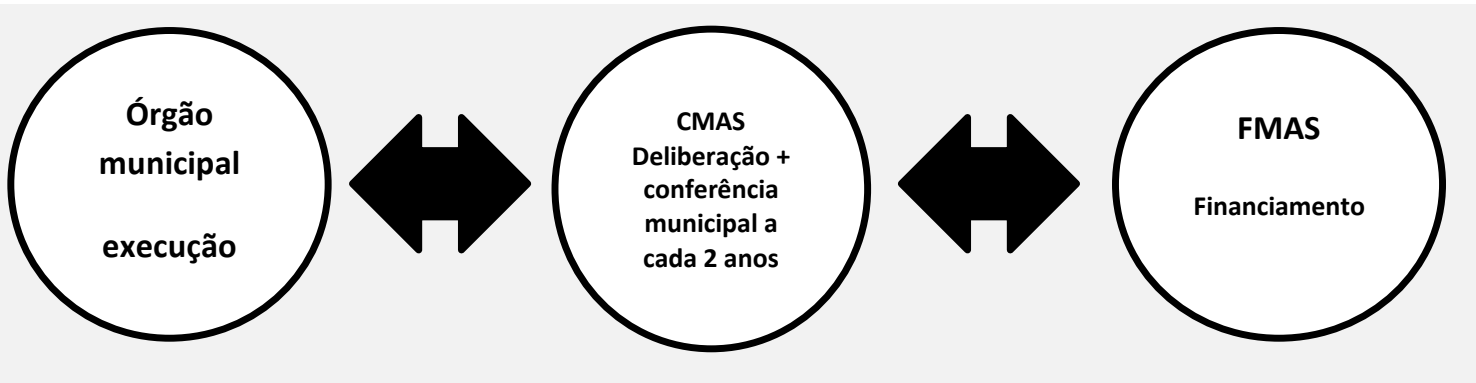

Fonte: elaboração própria.

Toda essa estrutura apresentada acima dialoga entre si, constituindo, assim, o sistema descentralizado e participativo da Assistência Social. No âmbito do CNAS são aprovadas as várias normativas que orientam a política em todo o país. Essas normativas se referem a todas as questões necessárias para regular o sistema, sendo identificadas como as principais aprovadas pelo CNAS nos últimos dez anos as seguintes: i) Norma Operacional Básica do SUAS. Aprovada em 2005, dispõe sobre a forma de gestão e financiamento da política de assistência social. ii) Norma Operacional Básica de Recursos Humanos (NOB/RH). Aprovada em 2006, define sobre as questões pertinentes ao trabalho, como constituição de equipes de referência, contratações, dentre outros. iii) Tipificação Nacional de Serviços Socioassistenciais, que orienta sobre o padrão de qualidade dos serviços prestados, tendo sido aprovada em 2009.

Em 2011, o Congresso Nacional aprovou a nova Lei Orgânica de Assistência Social, que teve como base a Loas de 1993. Essa alteração se deu em decorrência da criação do Suas, sendo identificada pelo número 12. 435. Recebeu a alcunha de Loas Ampliada. Em setembro de 2015, o CNAS aprovou uma nova Resolução que ampliou, em comparação a Lei $n^{\circ} 12.435$ e outras normativas, a definição e a caracterização dos usuários da política quanto aos seus direitos e à sua participação na Política Pública de Assistência Social e no Sistema Único de Assistência Social. Trata-se da Resolução ${ }^{\circ}$ 11 , de 23/09/2015.

Outros dois documentos foram criados pela equipe técnica do Ministério do Desenvolvimento Social e Combate a Fome/MDS com o objetivo de influir e orientar tecnicamente na implantação dos Cras e do Paif (Serviço de Proteção e Atendimento Integral à Família). Em 2009, foi elaborado um caderno chamado Orientações Técnicas: Centro de Referência de Assistência Social - Cras, que trata, de forma didática, sobre 
como implantar uma unidade do Cras. Esse compêndio aborda questões desde as funções, o padrão de atendimento, entre outras sugestões de conteúdo e de organização até as questões relacionadas ao padrão da estrutura física e identificação do equipamento. Em 2012, foi publicado o caderno sobre as Orientações Técnicas sobre o Paif. Volume 1 e 2, também com linguagem didática, com vistas a orientar sobre como desenvolver os serviços de atendimento às famílias.

O conjunto dessas normativas e orientações é importante por elas regularem todo o sistema no território nacional, refletindo o trabalho realizado em conjunto entre o MDS e o CNAS, sendo também a referência documental para o desenvolvimento deste capítulo e para as análises posteriores. Segue abaixo um quadro síntese das normativas e orientações de referência para implantação do Suas. 
Quadro 4

Sobre as normativas e orientações referências no SUAS

\begin{tabular}{|c|c|c|c|}
\hline Normativa & Objetivo & $\begin{array}{l}\text { Número da } \\
\text { Resolução }\end{array}$ & $\begin{array}{r}\text { Data da } \\
\text { Resolução }\end{array}$ \\
\hline $\begin{array}{l}\text { Política } \\
\text { Assistência } \\
\text { (PNAS/2004) }\end{array}$ & $\begin{array}{l}\text { Estabelece as diretrizes da Política Nacional } \\
\text { de Assistência Social e a criação do Suas. }\end{array}$ & 145 & $\begin{array}{c}\text { DOU } \\
28 / 10 / 2004\end{array}$ \\
\hline $\begin{array}{l}\text { Norma Operacional } \\
\text { Básica do SUAS. }\end{array}$ & 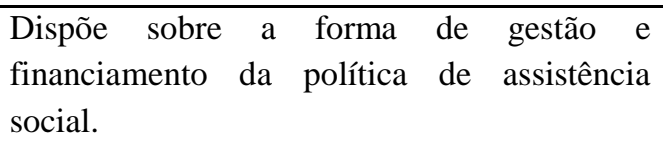 & 130 & $15 / 07 / 2005$ \\
\hline $\begin{array}{l}\text { Norma Operacional } \\
\text { Básica de Recursos } \\
\text { Humanos (NOB/RH). }\end{array}$ & Dispõe sobre os recursos humanos no Suas. & 269 & $\begin{array}{l}13 / 12 / 2006 \\
\text { DOU } \\
26 / 12 / 2006\end{array}$ \\
\hline $\begin{array}{lr}\text { Tipificação } & \text { Nacional } \\
\text { de } & \text { Serviços } \\
\text { Socioassistenciais. }\end{array}$ & $\begin{array}{l}\text { Orienta sobre o padrão de qualidade dos } \\
\text { serviços prestados. }\end{array}$ & 109 & $\begin{array}{c}\text { DOU } \\
25 / 11 / 2009\end{array}$ \\
\hline $\begin{array}{l}\text { "Loas Ampliada" } \\
\text { (elaborada partir da } \\
\text { Loas de 1993) }\end{array}$ & Institui legalmente o Suas & Lei $\mathrm{n}^{\circ} 12.435$ & $6 / 07 / 2011$ \\
\hline $\begin{array}{l}\text { Resolução } r \\
\text { usuários (revoga a } \\
\text { Resolução n }{ }^{\circ} \text { 24, de } \\
16 \text { de fevereiro de } \\
2006)\end{array}$ & $\begin{array}{l}\text { Caracteriza os usuários, seus direitos e sua } \\
\text { participação na Política Pública de } \\
\text { Assistência Social e no Sistema Único de } \\
\text { Assistência Social. }\end{array}$ & 11 & $23 / 09 / 2015$ \\
\hline $\begin{array}{l}\text { Orientações Técnicas: } \\
\text { Centro de Referência } \\
\text { de Assistência Social } \\
\text { - CRAS }\end{array}$ & $\begin{array}{l}\text { São orientações técnicas com abordagem } \\
\text { didática dirigida especialmente para gestores } \\
\text { e técnicos; orientam como implantar um } \\
\text { Cras. }\end{array}$ & $\begin{array}{l}\text { Produção } \\
\text { técnica do } \\
\text { MDS }\end{array}$ & $\begin{array}{l}\text { 2009, com } \\
\text { reimpressão } \\
\text { em } 2012 .\end{array}$ \\
\hline $\begin{array}{l}\text { Orientações Técnicas } \\
\text { sobre o Paif. Volume } \\
1 \text { e } 2\end{array}$ & $\begin{array}{l}\text { São orientações técnicas com abordagem } \\
\text { didática dirigida especialmente para gestores } \\
\text { e técnicos e orientam sobre a qualidade dos } \\
\text { serviços prestados. }\end{array}$ & $\begin{array}{l}\text { Produção } \\
\text { técnica do } \\
\text { MDS }\end{array}$ & 2012 \\
\hline
\end{tabular}

Fonte: elaboração própria.

A fundamentação conceitual do Suas se sustenta nas definições e nas orientações da PNAS/2004, que concebe a assistência social como uma política de proteção social, devendo garantir atendimento a todos que dela necessitarem, sem prévia contribuição. A proteção social deve considerar as pessoas, as suas circunstâncias e, dentre elas, seu núcleo de apoio que é a família, ${ }^{58}$ percebendo-as no cotidiano, pois é nele que os riscos

\footnotetext{
${ }^{58}$ Por "família" a política de Assistência Social (PNAS, 2004) compreende se tratar de um núcleo afetivo, vinculado por laços consanguíneos de aliança ou por afinidade, que circunscrevem obrigações recíprocas e mútuas, organizadas em torno de relações de geração e de gênero. Portanto, o direito à convivência familiar supera o conceito de família como unidade econômica, mera referência de cálculo de rendimento per capita e a entende como núcleo central de acolhida, convívio, autonomia, sustentabilidade e protagonismo social.
} 
e as vulnerabilidades se constituem. Compete ao Estado assegurar o atendimento e o acompanhamento desses sujeitos em seus territórios, de modo proativo, protetivo, preventivo, assegurando o acesso a direitos e a melhoria da qualidade de vida. Nesse sentido, o Suas é o sistema responsável pela organização e gestão da proteção social não contributiva no país, devendo ser descentralizado e participativo, além de assegurar em sua estrutura a proteção social em diferentes níveis de complexidade, tais como a Proteção Social Básica (PSB) e a Proteção Social Especial (PSE), podendo esta última ser de média e de alta complexidade.

Compreende-se por Proteção Social Básica um conjunto de serviços, programas, projetos e benefícios da assistência social que visam prevenir situações de vulnerabilidade e risco social por meio do desenvolvimento de potencialidades, de aquisições e do fortalecimento de vínculos familiares e comunitários. A Proteção Social Especial (PSE) é destinada às pessoas e às famílias que ainda mantêm vínculos familiares e comunitários, mas vivenciaram experiências de violação de direitos. A essas pessoas são ofertados um conjunto de serviços, de programas e de projetos que têm por objetivo contribuir para a reconstrução de vínculos familiares e comunitários, fortalecendo as potencialidades e aquisições, além de proteção às famílias e indivíduos para o enfrentamento das situações de violação de direitos. A PSE pode ser de média e de alta complexidade. A PSE de média complexidade é dirigida às pessoas que estão em situação de risco pessoal e social, mas que ainda possuem um ponto nodal em relação à família e à comunidade. São pessoas que não perderam totalmente seus vínculos. É o caso, por exemplo, de adolescentes com Medida Socioeducativa de Liberdade Assistida ou situações de violência doméstica não extremada. A PSE de alta complexidade visa atender aqueles que, por diversas razões, não têm mais nenhum vínculo familiar ou comunitário e precisam de uma intervenção complexa do Estado. Um exemplo clássico são os moradores de rua que, para terem seu direito assegurado, precisam de uma intervenção que garanta desde a moradia até a inserção no mundo do trabalho. Sem saúde, endereço, documentos, qualificação profissional, nenhum individuo é cidadão e sequer tem condições de gozar de algum nível de autonomia. 


\section{Figura 4}

\section{Escala de Risco para atendimento no SUAS}

\section{Sistema Único da Assistência Social}

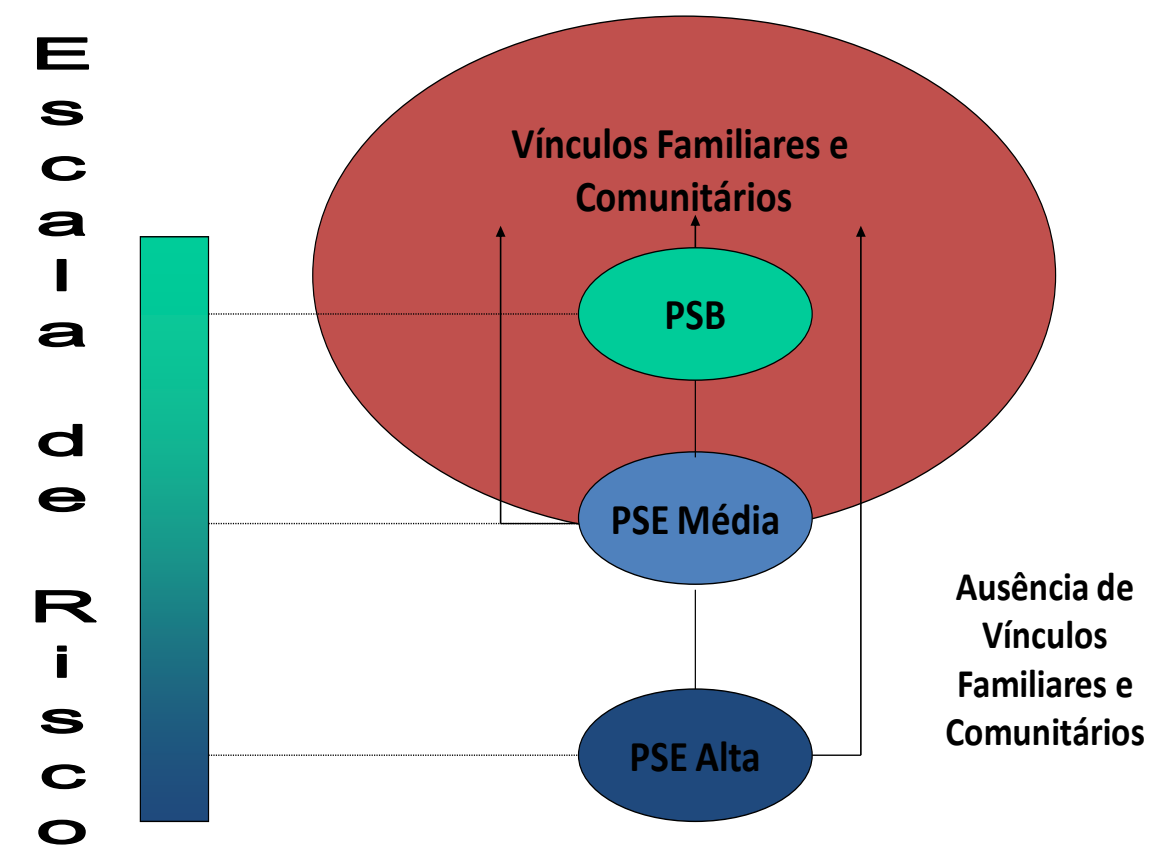

Fonte: Ministério do Desenvolvimento Social e Combate à Fome, Secretaria Nacional de Assistência Social, 2005.

É da competência do Suas: i) assegurar a consolidação da gestão compartilhada, o cofinanciamento e a cooperação técnica entre os entes federativos; ii) integrar a rede pública e privada de serviços, programas, projetos e benefícios de assistência social; iii) estabelecer as responsabilidades dos entes federativos na organização, regulação, manutenção e expansão das ações de assistência social; iii) definir os níveis de gestão, respeitadas as diversidades regionais e municipais; iv) implementar a gestão do trabalho e a educação permanente na assistência social; v) estabelecer a gestão integrada de serviços e benefícios; vi) afiançar a vigilância socioassistencial e a garantia de direitos.

A Loas Ampliada define três grande objetivos para o Suas: i) assegurar proteção como garantia da vida, a redução de danos e a prevenção da incidência de riscos; ii) assegurar a vigilância socioassistencial, que visa a analisar territorialmente a capacidade protetiva das famílias e nela a ocorrência de vulnerabilidades, de ameaças, de vitimizações e danos; iii) assegurar a defesa de direitos, que visa a garantir o pleno acesso aos direitos no conjunto das provisões socioassistenciais. Com base nesses objetivos a Assistência Social realiza o cadastramento das pessoas e famílias no 
Cadastro Único ou CadÚnico, ${ }^{59}$ que, por sua vez, possibilita a inserção das pessoas e famílias em vários benefícios e serviços. Um deles, previsto na CF-88 é o Beneficio de Prestação Continuada (BPC). ${ }^{60}$ Trata-se de um beneficio não vitalício e intransferível que se dá pela transferência de um salário mínimo mensal. É destinado à pessoa idosa a partir de 65 anos, à pessoa com deficiência de qualquer idade com impedimentos de longo prazo, de natureza física, mental, intelectual ou sensorial sendo, em ambos os casos, necessária a comprovação de não possuir meios de garantir o próprio sustento, nem tê-lo provido pela família. A renda mensal per capita familiar deve ser inferior a $1 / 4$ (um quarto) do salário mínimo vigente.

Outro beneficio por transferência de renda é o Programa Bolsa Família (PBF), que visa atender famílias em situação de pobreza e de extrema pobreza em todo o país. O PBF integra o Plano Brasil Sem Miséria (BSM). O perfil e os tipos de benefícios são: o básico, variável, variável vinculado ao adolescente (BVJ), variável gestante (BVG), variável nutriz (BVN) e o Benefício para Superação da Extrema Pobreza (BSP). Os valores dos benefícios pagos pelo $\mathrm{PBF}^{61}$ variam de acordo com as características de

59 O Cadastro Único ou CadÚnico é um instrumento de coleta de dados e informações que objetiva identificar todas as famílias de baixa renda existentes no país para fins de inclusão em programas de assistência social e redistribuição de renda. Criado no governo de Fernando Henrique Cardoso, em 24/10/2001, passou por duas regulamentações posteriormente (Decreto ${ }^{\circ} 6.135$ de 26/06/2007 e Portaria $\mathrm{n}^{\circ} 376$ de 16/10/2008). Compõe-se de uma base de dados e de instrumentos, procedimentos e sistemas eletrônicos. Sua base de informações pode ser usada pelos governos municipais, estaduais e federal a fim de propiciar o diagnóstico socioeconômico das famílias cadastradas. O cadastramento das famílias é executado por 5.489 órgãos gestores municipais da Assistência Social (dados do Censo Suas de 2014) e os cadastros são processados pelo Agente Operador do Cadastro Único, que é a Caixa Econômica Federal, responsável por fornecer, para cada pessoa da família cadastrada, um número de identificação social (NIS) de caráter único, pessoal e intransferível.

${ }^{60} \mathrm{O}$ Beneficio de Prestação Continuada da Assistência Social (BPC) foi instituído pela Constituição Federal de 1988 e regulamentado pela Lei Orgânica de Assistência Social - Loas, Lei $n^{\circ}$ 8.742, de 07/12/1993; pelas Leis $\mathrm{n}^{\mathrm{o}} 12.435$, de 06/07/2011 e $\mathrm{n}^{\mathrm{o}} 12.470$, de 31/08/2011, que alteram os dispositivos da Loas, e, também, pelos Decretos no 6.214, de 26/09/2007, e nº 6.564, de 12/09/2008.

O BPC é um beneficio da Política de Assistência Social, que integra a Proteção Social Básica no âmbito do Sistema Único de Assistência Social/Suas. Para acessá-lo não é necessário ter contribuído com a Previdência Social. A gestão do BPC é realizada pelo Ministério de Desenvolvimento Social e Combate à Fome (MDS), sendo a operacionalização realizada pelo Instituto Nacional do Seguro Social (INSS). Os recursos para o custeio provêm da Seguridade Social, administrado pelo MDS e repassado ao INSS, por meio do Fundo Nacional de Assistência Social (FNAS).

Além do repasse financeiro, a Assistência Social desenvolve um projeto denominado BPC na escola que visa adotar medidas que assegurem a presença de crianças e adolescentes beneficiárias na escola. Para tal, são assegurados transporte e cadeiras escolares adaptadas, adequação das instalações físicas para acessar as salas de aula e orientações às famílias e às equipes escolares. Com essas medidas de 2007 a 2014, 310 mil beneficiários de até 18 anos foram inseridos na rede de educação.

Dados disponíveis em: <http://mds.gov.br/assuntos/assistencia-social/beneficios-assistenciais/bpc >, e $<$ http://agenciabrasil.ebc.com.br/politica/noticia/2015-07/populacao-podera-conversar-com-ministros-emnova-plataforma-do-governo>. Acesso em: 12 ago. 2015.

${ }^{61} \mathrm{O}$ valor que a família recebe por mês é a soma de vários tipos de benefícios previstos no Programa Bolsa Família. Os tipos e as quantidades de benefícios que cada família recebe dependem da composição (número de pessoas, idades, presença de gestantes, etc.) e da renda da família beneficiária e podem ser 
cada família, considerando a renda mensal da família por pessoa, o número de crianças e adolescentes de até 17 anos, de gestantes, nutrizes e de componentes da família.

Para ofertar os serviços socioassistenciais, a estrutura do Suas foi organizada de acordo com a caracterização das proteções sociais. Na PSB, os serviços socioassistenciais são de base municipal e são instalados em territórios identificados pelo órgão gestor da Assistência Social como áreas de vulnerabilidade social. ${ }^{62}$ É destinado à população que vive em risco pessoal e social decorrente da pobreza, privação e/ou fragilização de vínculos afetivos - relacionais e de pertencimento social (discriminações etárias, étnicas, de gênero ou por deficiências, dentre outras).

Com vistas ao gerenciamento e oferta de serviços foram instituídos os Cras, que funcionam como a principal porta de entrada do sistema nesse nível de atendimento. Os Cras, de acordo com a PNAS/2004, é uma unidade pública estatal de base territorial, responsável pela coordenação e organização da rede de serviços socioassistenciais local ${ }^{63}$ e execução de serviços de proteção social básica, sendo essa oferta de serviços no equipamento condicionada às condições do espaço físico, materiais e de recursos humanos da unidade.

conhecidos e calculados no seguinte endereço eletrônico: <http://mds.gov.br/assuntos/bolsa-familia/oque-e/beneficios/beneficios>. Acesso em: 15 nov. 2015.

${ }^{62}$ Como foi apresentado na Introdução, o conceito de vulnerabilidade social é de natureza complexa e multifacetada. Compreende-se não sinônimo de pobreza, e sim esta ser condição para agravar a situação das pessoas e das famílias, sendo que isso pode ocorrer por um período ou permanecer ao longo da vida. A ausência de intervenção pode causar uma situação de risco, comprometendo ciclos intergeracionais.

${ }^{63}$ No geral, os serviços da proteção básica local ocorrem por meio do atendimento realizado por várias unidades no território, que podem ser estatais e/ou filantrópicas, constituindo uma rede. Compete ao Cras, enquanto unidade pública estatal, a gestão territorial dessa rede local de forma que sejam assegurados: serviços de proteção às famílias; inclusão produtiva e projetos de enfrentamento da pobreza; centros de convivência para idosos; serviços para crianças de 0 a 6 anos; serviços socioeducativos para crianças, adolescentes e jovens na faixa etária de 6 a 24 anos; programas de incentivo ao protagonismo juvenil e de fortalecimento dos vínculos familiares e comunitários; centros de informação e de educação para o trabalho, voltados para jovens e adultos. 


\section{Figura 5}

\section{Proteção social básica no território: o Cras e a rede de serviços socioassistenciais}

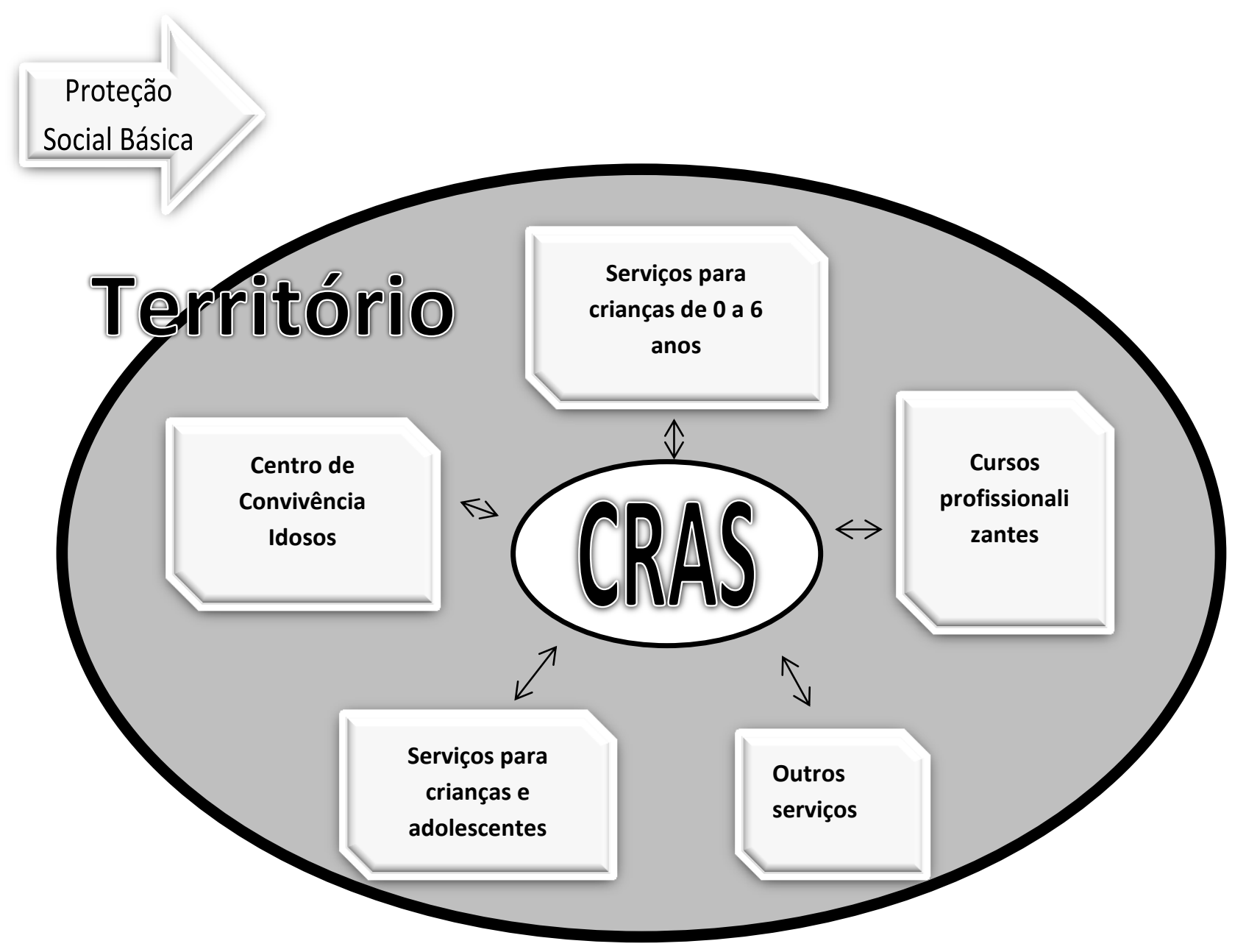

Fonte: elaborado pela autora.

Todos os Cras devem desempenhar as funções de gestor da proteção básica no seu território e ofertar o Paif, ${ }^{64}$ que consiste na oferta de ações e serviços socioassistenciais de prestação continuada, com vistas a prevenir o rompimento dos

\footnotetext{
${ }^{64}$ O Serviço de Proteção e Atendimento Integral à Família (Paif) tem suas bases no Programa Nacional de apoio à família/NAF, instituído em 2001. Posteriormente, em 2003, foi expandido e aperfeiçoado, sendo lançado como Plano Nacional de Atendimento Integral à Família - Paif (Portaria $\mathrm{n}^{\circ} 78$ de 08/04/2004). Em 2004, o Plano foi ajustado às bases do Suas e incorporado à Política Nacional de Assistência Social/PNAS, que passou a institui-lo como Programa de Atenção Integral à Família, sendo sua oferta obrigatória e exclusiva nos Cras (Decreto n ${ }^{\circ}$ 5.085, de 19/05/2004). Em 2009, após muitos debates para a aprovação da Tipificação Nacional de Serviços Socioassistenciais, passou a ser denominado e reconhecido como Serviço de Proteção e Atendimento Integral à Família (Paif). Essa mudança da nomenclatura veio no sentido de corroborar com o conceito de ação continuada estabelecida pela Loas e também reconhecer que as vulnerabilidades e os riscos sociais que atingem as famílias exigem intervenções continuadas que trabalhem aspectos objetivos e subjetivos relacionados à função protetiva da família e ao direito à convivência familiar.
} 
vínculos familiares e a violência no âmbito de suas relações. Dessa forma, em todos os Cras são realizados os seguintes serviços: acolhida; estudo social; visita domiciliar; orientação e encaminhamentos; grupos de famílias; acompanhamento familiar; atividades comunitárias; campanhas socioeducativas; informação, comunicação e defesa de direitos; promoção do acesso à documentação pessoal; mobilização e fortalecimento de redes sociais de apoio; desenvolvimento do convívio familiar e comunitário; mobilização para a cidadania; conhecimento do território; cadastramento socioeconômico; elaboração de relatórios e/ou prontuários; notificação da ocorrência de situações de vulnerabilidade e risco social; busca ativa.

\section{Figura 6}

\section{Cras: unidade pública que abriga os serviços de prestação continuada (Paif)}

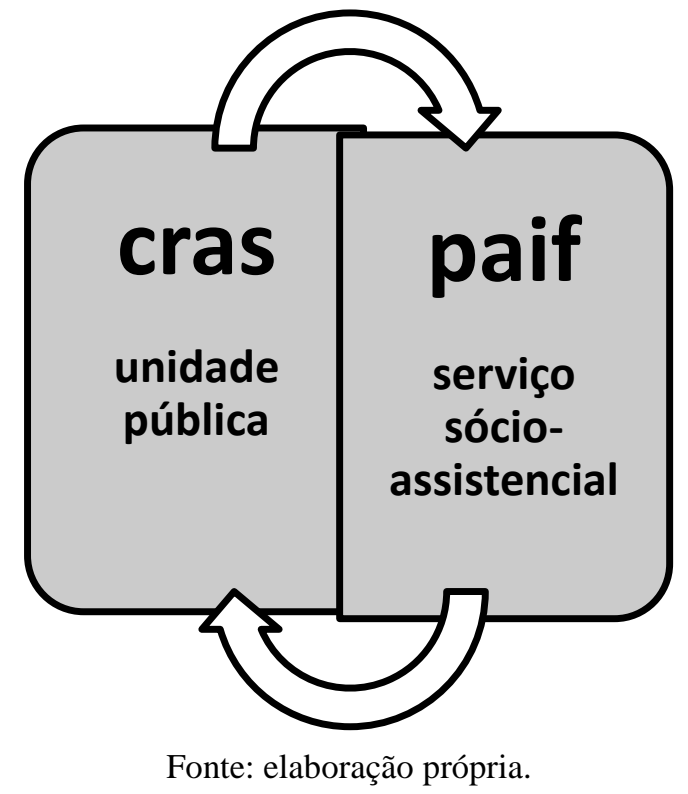

O Paif foi regulado pela Resolução $\mathrm{n}^{\circ}$ 109, de 11 de novembro de 2009, que aprova a Tipificação Nacional de Serviços Socioassistenciais (anexo à normativa). Ela aponta para a necessidade de o Paif utilizar de ações culturais para o cumprimento de seus objetivos. "O trabalho social do Paif deve utilizar-se também de ações nas áreas culturais para o cumprimento de seus objetivos, de modo a ampliar o universo informacional e proporcionar novas vivências às famílias usuárias do Serviço” (2009, p. 6). Considera-se que os usuários desse serviço são as famílias em situação de vulnerabilidade social em decorrência da pobreza ou do precário ou nulo acesso aos serviços públicos, ou, ainda, aquelas com fragilidades em seus vínculos de 
pertencimento e de sociabilidade que sejam residentes nos territórios de abrangência dos Cras. A normativa considera em especial:

i) Famílias beneficiárias de programas de transferência de renda e benefícios
assistenciais; ii) Famílias que atendem os critérios de elegibilidade a tais
programas ou benefícios, mas que ainda não foram contempladas; iii)
Famílias em situação de vulnerabilidade em decorrência de dificuldades
vivenciadas por algum de seus membros; iv) Pessoas com deficiência e/ou
pessoas idosas que vivenciam situações de vulnerabilidade e risco social.
(Resolução ${ }^{\circ} 109$, de 11 de novembro de 2009 , anexo, p. $7-9$ )

Nota-se que constituem as famílias beneficiárias de programas de transferência de renda e benefícios assistenciais 13,9 milhões de famílias pelo Programa Bolsa Família, ${ }^{65}$ beneficiando diretamente 50 milhões de pessoas pobres, sendo que em 2013 a meta do governo era ampliar o atendimento para mais 700 mil famílias ${ }^{66}$ em situação de miséria, ou seja, brasileiros que vivem em lares cuja renda familiar mensal é de $\mathrm{R} \$ 70$ por pessoa em média. O ingresso de usuários no Programa Bolsa Família constitui uma atribuição do Cras, que, por meio do serviço de Busca Ativa, localiza essas famílias, podendo o cadastramento no PBF ocorrer ou não na unidade do Cras, a depender da estrutura física e de recursos humanos alocados na Assistência Social, da localização do equipamento no município, entre outros fatores. Porém, todos os Cras devem realizar esse serviço, a fim de identificar pessoas em seus territórios que tenham o perfil do PBF, além de assegurar a inserção dessas pessoas em outros serviços e programas socioassistenciais.

A fim de operar serviços do Paif, tais como campanhas socioeducativas, informação, comunicação e defesa de direitos, desenvolvimento do convívio familiar e comunitário e da mobilização para a cidadania (visando o desenvolvimento do protagonismo do usuário), o Cras deve assegurar materiais socioeducativos e instrumentos de comunicação, podendo essa produção e reprodução ser feita pelo próprio Cras ou por outro órgão indicado pelo município ou pelo Estado, ou ainda pelo próprio Ministério de Desenvolvimento Social e Combate à Fome (MDS).

\footnotetext{
${ }^{65}$ Dado informado pelo MDS em 17 de setembro de 2015. Disponível em: <http://mds.gov.br/area-deimprensa/noticias/2015/setembro/numero-de-beneficiarios-do-bolsa-familia-tem-se-mantido-estavel $>$. Acesso em: 15 nov. 2015.

${ }^{66}$ De acordo com o site do MDS, o governo estimava a existência de 700 mil famílias em situação de miséria e que precisavam ser identificadas. Para tal, o governo iniciou uma campanha, por meio de seu site, em que divulga o vídeo $O$ fim da miséria é só o começo no YouTube. A proposta era reforçar o trabalho de 'busca ativa' dos Cras. Dados indicam que, por meio do 'busca ativa', foram localizadas cerca de 791 mil famílias. Matéria publicada pelo site do MDS em 22 de fevereiro de 2013. Disponível em: <http://www.mds.gov.br/saladeimprensa/noticias/2013/02/busca-ativa-localizou-791-mil-familiasextremamente-pobres>. Acesso em: 15 nov. 2015.
} 
As normativas orientam ainda que "a efetividade do Paif depende do investimento dos municípios, na promoção da intersetorialidade local, bem como do estabelecimento de fluxos, no âmbito do território do Cras". O resultado esperado com essa integração é a "segurança de desenvolvimento da autonomia, sendo a melhoria da qualidade de vida das famílias residentes no território de abrangência do CRAS o impacto social esperado" (Orientações Técnicas Centro de Referência de Assistência Social - Cras, 2012, p. 8-9).

A recente Resolução $n^{\circ} 11$, de 23 de setembro de 2015, caracteriza quem são os usuários da política de Assistência Social, define que estes são cidadãos, sujeitos de direitos e coletivos que se encontram em situações de vulnerabilidade e riscos social e pessoal, que acessam os serviços, programas, projetos, benefícios e transferência de renda no âmbito da Política Pública de Assistência Social e no Suas. A Resolução afirma ainda que os usuários de tais serviços têm direitos a: i) ter acesso a atendimento, assessoramento, defesa e garantia de direitos, que lhes garanta suporte socioassistencial; ii) ter acesso a informações e orientações sobre serviços, programas, projetos, benefícios e transferência de renda, no âmbito da Política Pública de Assistência Social, em linguagem clara, simples e acessível; iii) usufruir do reconhecimento de seus direitos frente à sociedade; iv) usufruir de serviços e programas socioassistenciais de qualidade. A Resolução trata ainda de um padrão de qualidade dos serviços e das informações prestados ao usuário, que variam desde o direito à transparência no atendimento até as condições de expressar suas opiniões, além do acesso ao serviço de qualidade orientado às suas necessidades. A Resolução apresenta os indicadores do padrão de qualidade no atendimento relacionados no quadro abaixo. 
Quadro 5

Padrão de Qualidade do atendimento

PADRÃO DE QUALIDADE DOS SERVIÇOS E DAS INFORMAÇÕES PRESTADAS AOS USUÁRIOS

1- Conhecer o nome e a credencial de quem o atende.

2- Ser atendido com menor tempo de espera e de acordo com as suas necessidades.

3- Receber os encaminhamentos para outros serviços ou instituições por escrito, de forma clara e legível, identificados com o nome do profissional responsável pelo encaminhamento.

4- Ter informações e orientações sobre como manifestar suas demandas e necessidades no campo da assistência social por serviços, programas, projetos, benefícios e transferência de renda no âmbito da Política Pública de Assistência Social.

5- Ter seu registro realizado nos prontuários que lhe dizem respeito, se assim o desejar.

6- Ter informações sobre organizações públicas e privadas que oferecem suporte para o desenvolvimento de produções coletivas, associadas ou cooperativadas.

7- Ter acesso a quaisquer informações que possam contribuir para a construção de sua autonomia como sujeito de direitos, visto o reconhecimento da importância da sua intervenção na vida pública e no acesso a oportunidades para o exercício do protagonismo social e político e da sua cidadania.

8- Ter acessibilidade às tecnologias assistivas asseguradas a todos os usuários.

9- Ter acesso a atividades de convivência e de fortalecimento de vínculos, ancoradas na cultura local e na laicidade do Estado.

10- Ter a possibilidade de avaliar o serviço recebido, contando com espaço de escuta para expressar sua opinião.

Fonte: Resolução n 11, 23/09/2015. Elaborado pela autora.

A Resolução também aborda a respeito da participação dos usuários na política de Assistência Social e no Suas e determina que ela se dará por meio de diferentes organizações coletivas, que visem promover a mobilização e a organização de usuários, influindo nas instâncias de deliberação do Suas - os conselhos e as conferências. Dessa forma, a Resolução reconhece a relevância de se construir uma sociedade democrática, assegurando o direito de pessoas, famílias e coletivos de se comunicar com as instâncias do Suas na condição de cidadãos usuários e de direitos. Determina, por fim, que gestores públicos estatais ou entidades ou Organizações de Assistência Social e Trabalhadores do Suas não representam os usuários nas instâncias deliberativas do Suas 
- nos conselhos e nas conferências de Assistência Social. Na atualidade, o Suas está constituído em todos os munícipios do país, sendo que, de acordo com o Censo Suas 2014, em $4.279^{67}$ municípios existe ao menos uma secretaria municipal exclusiva da área de Assistência Social, sendo que 61\% destas possuem oficialmente uma gerência de proteção social básica responsável pelos Cras, que totalizam $8.088^{68}$ em todo o país.

Nas Orientações Técnicas Centro de Referência de Assistência Social - Cras, publicada pelo MDS em 2009 e reimpresso em 2012, especificamente na página 58, há um item que trata da norma sobre a 'identificação do CRAS'. "Todos os Cras deverão receber identificação por meio de uma placa, ${ }^{69}$ de modo a garantir a visibilidade da unidade e o acesso facilitado das famílias beneficiárias, bem como sua vinculação ao Suas". Além disso, destaca-se nesse documento as orientações sobre a estrutura do espaço físico do Cras, que "deve ser reflexo de uma concepção". O Cras deve ser organizado de modo que as famílias o reconheçam como uma unidade pública que possibilite o acesso aos direitos constitucionais.

Assim, os CRAS não podem ser instalados em edificações inadequadas e improvisadas e devem conter: recepção; sala de atendimento; sala de uso coletivo; sala administrativa; copa e banheiros. Para cada um desses ambientes há um detalhamento e orientações que vão desde a sugestão de metragem, de iluminação, de ventilação, de conservação, de privacidade, de salubridade, de limpeza e, também, sugestões de cartazes, murais, dentre outros instrumentos de informação.

Nesse documento sobre o mobiliário, a orientação é que as mobílias devem ser adequados aos ambientes do Cras, devendo este adquirir materiais e recursos de comunicação, tais como: livros, CD's, DVD's, televisor, aparelho de DVD, aparelho de som, microfone, máquina fotográfica, dentre outros. Sugere-se ser determinante que o Cras disponha de equipamentos e condições de conectividade que permitem agilidade dos processos de trabalho e maior interação com a rede socioassistencial e setorial, tais como linha telefônica e computador com internet, além de automóvel, sobretudo para a realização de visitas domiciliares e para o acompanhamento de famílias em áreas dispersas do território de abrangência do Cras. A organização do espaço físico do Cras

67 De acordo com o IBGE, atualmente são 5.570 munícipios no Brasil. Disponível em: <http://7a12.ibge.gov.br/voce-sabia/curiosidades/municipios-novos>. Acesso em: 25 set. 2015. ${ }^{68}$ Censo Suas 2014.

${ }^{69}$ A placa de identificação do Cras possui uma identidade visual, cujo modelo e especificações padrão encontram-se disponíveis no sítio do Ministério do Desenvolvimento Social e Combate à Fome (<http://www.mds.gov.br>, na seção "Suas", campo "Proteção Social Básica"). Pode ser vista também no caderno de Orientações Técnicas Centro de Referência de Assistência Social - Cras, publicado pelo MDS, reimpresso em 2012. 
deve considerar a diversidade do público de modo a respeitar as especificidades de todos os membros das famílias: crianças pequenas, adolescentes, jovens, idosos e pessoas com deficiência.

Essas orientações técnicas do MDS estabelecem um Índice de Desenvolvimento do Cras para a estrutura física, para o funcionamento do Cras e para os recursos humanos, uma vez que se estabelece desde a carga horária de funcionamento do equipamento à proporção de profissionais para o número de atendidos, bem como as atribuições do coordenador de Cras e da equipe técnica de nível médio e superior com enfoque no trabalho interdisciplinar. Os 256.858 trabalhadores possuem vínculos empregatícios com os órgãos gestor municipais de Assistência Social, sendo que 95.325 atuam nos Cras, compondo as equipes de referência como mostra a tabela abaixo por região.

Tabela 3 - Trabalhadores nos Cras, por região do país

\begin{tabular}{|l|c|c|}
\hline \multicolumn{3}{|c|}{ Quantidade de trabalhadores nos CRAS, por região } \\
\hline \multicolumn{2}{|c|}{ Quantidade de trabalhadores } & $\%$ \\
\hline Norte & 9.355 & 9,8 \\
\hline Nordeste & 36.452 & 38,2 \\
\hline Sudeste & 28.423 & 29,8 \\
\hline Sul & 13.413 & 14,1 \\
\hline Centro-Oeste & 7.682 & 8,1 \\
\hline Total & 95.325 & 100,0 \\
\hline
\end{tabular}

Fonte: SNAS/DGSUAS/CGSVIS - Censo Suas 2014, p. 30.

De acordo com as informações desenvolvidas neste capítulo, podemos verificar que a Assistência Social adquiriu estrutura e organização correspondente a uma política pública, uma vez que está assegurada por lei (Loas ampliada), instituída por meio de um sistema de gestão e de execução da política (Suas), que funciona com controle social e fundo público. O Suas é dividido entre duas proteções: PSB, cuja unidade direta de atendimento são os Cras e a PSE, cuja unidade direta são os Creas. Todas as proteções sociais devem ser conduzidas por meio da estrutura do Estado, podendo os serviços socioassistenciais ser compartilhados com prestadores de serviços da sociedade civil, que são identificados como unidades indiretas. Os Cras são a principal porta de entrada do sistema por ter um caráter preventivo e se orientam pelo Paif. Os Creas atendem pessoas que vivenciaram experiências de violação de direitos, como informa o quadro abaixo: 
Figura 7

Síntese da política de Assistência Social

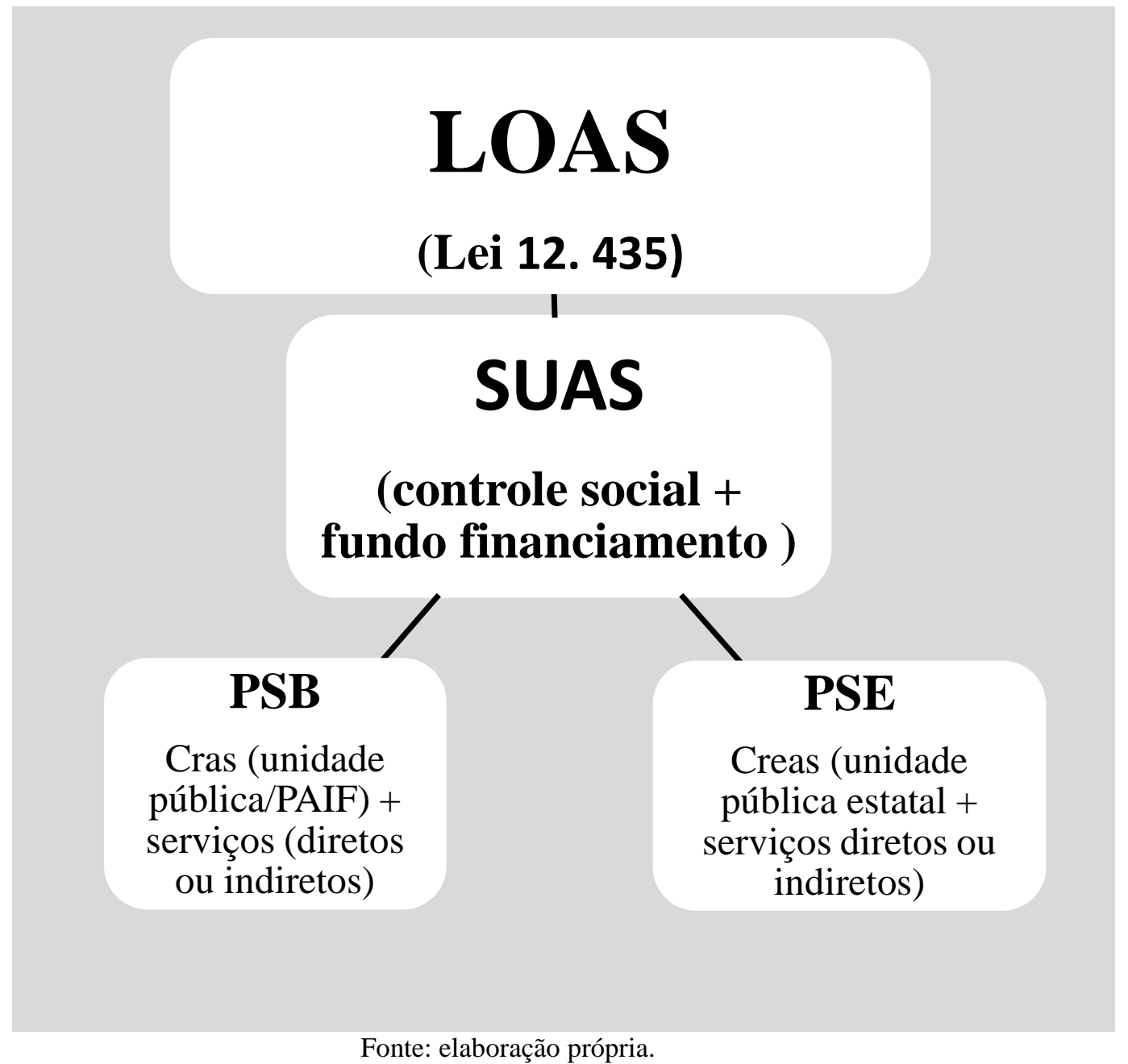

Fonte: elaboração própria.

Ainda de acordo com as informações apresentadas, constata-se que o Suas é uma realidade em todo território nacional, sendo uma política pública estruturada para redistribuir bens e serviços. A questão é: como tem sido realizada a comunicação junto aos usuários na prestação dos serviços nos Cras sob o contexto do neoliberalismo à brasileira, com disputas ideológicas internas à política, mas tendo o governo uma visão diferenciada para a questão social e para o enfrentamento à pobreza? Estaria essa comunicação afinada com os princípios da Comunicação Pública? Em que medida a comunicação de Estado, nos vários níveis de governo e tendo como referências as normativas e as orientações, para os Cras tem se dirigido para se constituir como uma Comunicação Pública efetiva na sua relação com os usuários? Para compreendermos essas questões, o capítulo quatro tem por proposta, por meio do resgate histórico e 
conceitual, desenvolver o entendimento sobre Comunicação Pública construído na contemporaneidade. 


\section{CAPÍTULO 4}

\section{Comunicação Pública: uma unidade técnico-ético-política da comunicação}

O estudo sobre a Comunicação Pública como um eixo transversal à política de Assistência Social tem relação com o que Bobbio (1992) denominou de gravidade do problema atual. Está posto em questão a proteção dos direitos do homem, e não mais a sua fundamentação. Para esse autor, os direitos do homem, a democracia e a paz são três momentos necessários do mesmo movimento histórico. Não é possível existir democracia sem o reconhecimento e a proteção dos direitos do homem. Tampouco é possível haver paz sem as condições necessárias à vida.

Lima (2010, p. 21) afirma que a comunicação é "um direito que se refere à liberdade individual e ao direito humano fundamental da palavra, da expressão". Tratase, portanto, de um direito que potencializa as condições para a autonomia e a igualitária participação dos indivíduos, inclusive, nas políticas sociais, uma vez que estas resultam de mediações complexas que se movimentam e disputam hegemonia nas esferas estatal, pública e privada. No entanto, é necessário ter clareza, para desvendar o objeto da pesquisa realizada, que informar não é comunicar. Wolton (2011), em publicação sobre os perigos que os novos meios de comunicação podem proporcionar aos homens, destaca que a comunicação é mais complexa que a informação porque comunicar requer uma relação com o outro, pois é por meio dela que os seres humanos podem compartilhar, convencer e seduzir - mesmo que esses três elementos não estejam explicitados. Para ele, na comunicação está presente a ideia de negociação, compartilhamento e relação, sendo que a informação está sempre ligada à mensagem e aos dados. Assim, de acordo com Lima (2013), quando a comunicação é de "mão dupla" toda "relação de poder" fica excluída, pois pressupõe uma igualdade entre os sujeitos capazes de, ao mesmo tempo, assegurarem o direito de voz e o direito de ser ouvido, sendo que o próprio conhecimento gerado pelo diálogo comunicativo só será verdadeiro e autêntico quando comprometido com a justiça e a transformação social. Nessa mesma direção apontou Freire (1994), em seu livro Pedagogia do Oprimido, ao afirmar ser a comunicação (embora esta possa se dar por meio de muitas linguagens) um encontro entre os homens mediados pela palavra, a fim de dar nome ao mundo, sendo por meio do diálogo que os homens transformam o mundo, e, ao transformá-lo, promovem a humanização de todos. 
É nessa perspectiva, tendo como referência Bourdieu (2004, p. 48) em sua afirmativa de que "o real nunca toma a iniciativa já que só dá resposta quando questionado", que o estudo sobre a Comunicação Pública na política de Assistência Social cresce em importância, uma vez que esse tema incide diretamente na constituição do Estado de direitos, na consolidação da democracia brasileira, no respeito aos trabalhadores usuários e, principalmente, no enfrentamento à cultura clientelista. Daí ser imprescindível compreender a Comunicação Pública em sua dimensão histórica, técnica, ética e política no país, a fim de identificar sua transversalidade com a Assistência Social.

No país, as experiências anteriores da comunicação como um serviço público foram marcadas por um viés autoritário, a exemplo do período Vargas (1930-1945) e do regime civil-militar (1964-1985), ${ }^{70}$ bem como por uma comunicação de governo com natureza publicitária, cujo objetivo era a divulgação das ações dos governos por meio da veiculação na grande mídia, e, por fim, menos usual, de cunho educativo, às vezes com um apelo cívico. ${ }^{71}$ A ideia da Comunicação Pública como meio e meta para o desenvolvimento da democracia tem sua origem, no Brasil, no movimento deflagrado, nos anos de 1980, pela Frente Nacional de Luta pela Democratização da Comunicação (FNLDC) que teve o auge da sua atuação durante a elaboração da CF-88.

O FNLDC, atual FNDC - Fórum Nacional pela Democratização da Comunicação, ${ }^{72}$ é um movimento social que integrava e integra ainda várias entidades

\footnotetext{
70 Jorge Duarte colabora com as informações de que no Brasil, por muito tempo, evitou-se falar em comunicação dentro de governos, até para não lembrar o DIP - Departamento de Imprensa e Propaganda - do período Vargas. Os objetivos implícitos desse setor estavam vinculados à estratégia de manipulação com vistas a um ideário fascista, populista e personalista e à censura. Posteriormente, a comunicação como um serviço público foi retomada pelo regime militar, que adotou um novo modelo de sistema de comunicação usando o então nome "moderno" de Relações Públicas. Na prática, fortaleceu-se a compreensão da comunicação como instrumento de persuasão social em um governo. Além de reafirmar preconceitos sobre comunicação de governo, esse período serviu também para ajudar a estigmatizar a prática das relações públicas. Disponível em:

<http://www.jforni.jor.br/forni/files/ComP\%C3\%BAblicaJDuartevf.pdf> e <http://redeescoladegoverno.fdrh.rs.gov.br/upload/1367323906_Jorge\%20Duarte.pdf>. Acesso em: 24 jan. 2016.

71 Brandão (2009) indica que as campanhas educativas se deram de modo mais intenso no campo da Saúde e da Agropecuária, a exemplo das campanhas de vacinação e o "Difusionismo" - modelo teórico de comunicação adotado pela extensão rural no período do desenvolvimentismo. Outras campanhas ocorridas no período militar estão ligadas ao incentivo de não jogar lixo na rua ("Sujismundo") e de incentivo à prática de atividades físicas ("Mexa-se").

72 O Fórum surgiu em julho de 1991 como movimento social e se transformou em entidade constituída em 20 de agosto de 1995. No entanto, sua história começou em 1984, com a criação da Frente Nacional por Políticas Democráticas de Comunicação (FNPDC). Em julho de 1994, o FNDC contava com a adesão de Comitês Regionais e Comissões pró-Comitês, além de 32 entidades nacionais e 364 entidades regionais. A lista pode ser encontrada no texto da ata de fundação do FNDC. A partir de 1997, pela conjuntura nacional e diversas outras razões, o FNDC se desarticulou, voltando apenas a se mobilizar a
} 
profissionais e intelectuais. Sua origem teve relação com os debates críticos iniciados nos anos de 1970, acerca das políticas de comunicação no período do desenvolvimentismo no Brasil, este ocorrido nas décadas de 1950 e de 1960. O início desse movimento também recebeu influências, em sua origem, da concepção de comunicação social da Igreja Católica latino-americana, bem como de um ideal histórico da comunicação. Outra contribuição que influenciou o movimento pela democratização da comunicação no Brasil foi a Nomic (Nova Ordem Mundial da Informação e Comunicação), vinculada à Unesco, que, por sua vez, gerou o Relatório MacBride ${ }^{73}$ que definiu a comunicação como um direito humano por estar vinculo à liberdade de expressão e à participação política, esta que é permeada por discussões de temas de interesse público. De acordo com o documento:

[...] todo mundo tem o direito de comunicar. Os elementos que integram esse direito fundamental do homem, sem que sejam de modo algum limitativos, são os seguintes: a) o direito de reunião, de discussão, de participação e outros direitos de associação; b) o direito de fazer perguntas, de ser informado, de informar e os demais direitos de informação; c) o direito à cultura, o direito de escolher, o direito à proteção da vida privada e outros direitos relativos ao desenvolvimento do indivíduo. (Ramos, 2005, p. 249)

Sob clima de redemocratização do país, considerando os 20 anos de ditadura civil-militar, a CF-88 foi elaborada com base em valores democráticos, o que alcançou também a comunicação, passando esta a ser reconhecida como um direito humano e

partir de meados de 2001, quando foi acelerado, no Congresso Nacional, o processo de desregulamentação da mídia brasileira, com a tramitação da PEC do capital estrangeiro. Atualmente, o Fórum está organizado em nove estados e é integrado por 15 entidades nacionais. Disponível em: <http://www.fndc.org.br/tire-sua-duvida/>. Acesso em: 16 jan. 2016.

${ }^{73}$ É no clima da Guerra Fria que a Organização das Nações Unidas para a Educação, Ciência e Cultura Unesco propõe a realização de um estudo sobre os problemas relativos à comunicação na sociedade contemporânea. O relatório "Um mundo e muitas vozes: comunicação e informação em nossa época" foi produzido por uma comissão instituída a partir da 19ª Conferência Geral, realizada em Nairóbi (Quênia) em 1976. É importante assinalar, conforme destaque do prof. Murilo Ramos em aula, no dia 16 de abril 2013, que esse documento foi deliberado em circunstâncias políticas em que estavam reunidos representantes de três blocos: os Estados Unidos e seus aliados; a União Soviética e seus aliados, e um grupo de países que se declaravam "não alinhados" - este último com inclinações a se aliar ao bloco liderado pelos soviéticos. Ramos (2005, p. 245) afirma que esse documento emerge entre os anos de 1960 e de 1970 em decorrência de vários fatores, tais como o desenvolvimento dos meios de comunicação e a necessidade de sua democratização, que se articulava aos âmbitos econômico e político da época, sendo necessário, em consequência, incorporar a compreensão de que "a comunicação é portadora de um novo direito social que é o direito a comunicação", tendo um papel para o fortalecimento da democracia. O autor considera ainda que esse vasto, denso e instigante documento, ainda que contraditório tendo em vista a heterogeneidade político-ideológica dos membros, é hoje o mais completo relato produzido sobre a comunicação na contemporaneidade. Participaram da Comissão Internacional para o Estudo dos Problemas da Comunicação os seguintes representantes: Seán MacBride (presidente, Irlanda), Elie Abel (EUA), Hubert Beuve-Méry (França), Elebe Ma Ekonzo (Zaire), Gabriel García Márquez (Colômbia), Sergei Losev (URSS), Mochtar Lubis (Indonésia), Mustapha Masmoudi (Tunísia), Michio Nagai (Japão), Fred Isaac Akporuaro Omu (Nigéria), Bogdan Osonik (Iugoslávia), Gamal El-Oteifi (Egito), Johannes Pieter Pronk (Holanda), Juan Somavía (Chile); Boobli George Verghese (Índia) e Betty Zimmerman (Canadá) (Unesco, 1983. p. 482-483). 
social de terceira geração. ${ }^{74}$ No artigo $5^{\circ}$, inciso XXXIII, foi assegurado a todos o direito de receber dos órgãos públicos informações de seu interesse particular, ou de interesse coletivo ou geral, sendo tais informações prestadas no prazo da lei, sob pena de responsabilidade, exceto aquelas cujo sigilo seja necessário à segurança da sociedade e do Estado. No capítulo V, sobre a Comunicação Social, assegurou-se o direito à liberdade de expressão, à proteção e defesa à pessoa e à sua família contra programas ou programações de rádio e televisão que se mostrem inadequadas; à democratização dos meios de comunicação social, coibindo o monopólio ou oligopólio, inclusive controlando a participação de grupos estrangeiros; e a constituição do Conselho de Comunicação Social como um órgão auxiliar do Congresso Nacional.

Inscreveu-se, portanto, na Carta $\mathrm{Magna}^{75}$ a comunicação como um direito fundamental, que significa assegurar o poder de comunicar aos brasileiros por meio da transparência e da fidedignidade nas informações veiculadas pelo Estado por meio de seus organismos; da regulação e do controle das concessões dos meios de comunicação; e da garantia do "acesso do cidadão e de suas organizações coletivas aos meios de comunicação social na condição de emissores - produtores e difusores - de conteúdos" (Peruzzo, 2004, p. 57). No entanto, em que pese a CF-88 ter sido elaborada sob a efervescência da redemocratização do país, com participação ativa dos movimentos sociais, sob o espírito de integrar a comunicação como um dos direitos fundamentais, ${ }^{76}$ a sua regulação tem se dado em uma conjuntura em que a comunicação social é simultaneamente mercadoria e direitos fundamentais. Isso porque o final do século XX foi marcado pela a revolução multimídia que, além de potencializar a dissolução de fronteiras entre as tecnologias utilizadas nas telecomunicações, comunicação de massa e da informática, ou entre o telefone, a televisão e o computador, apresenta-se como um novo território de valorização do capital, agora impulsionado pelas privatizações da economia e pelas desregulamentações das políticas estatais. Assim, engendra-se a formação de um mercado unificado com companhias mundializadas, configurando-se, em base planetária, concepções, produção e distribuição de produtos e serviços, numa “encarniçada concorrência entre oligopólios, que se dá especialmente por meio do controle mundial dos insumos: matérias-primas no Terceiro Mundo e insumos

\footnotetext{
${ }^{74}$ Os direitos civis e políticos são considerados de primeira geração e os direitos sociais como de segunda geração. "Os direitos coletivos e os que pregam o respeito às diferenças são de terceira geração" (Peruzzo, 2004, p. 63).

${ }^{75}$ Trata-se do capítulo V - da comunicação social, artigos 220 a 224 da Constituição Federal de 1988.

${ }^{76}$ São reconhecidos como direitos fundamentais na CF-88 a liberdade religiosa, a liberdade de opinião, de pensamento e de expressão, a liberdade de imprensa e, ainda, a liberdade de reunião e de associação.
} 
tecnológicos - em geral dentro da tríade"77 (Chesnais apud Behring, 2003, p. 45). Para Lima (2004), a mundialização desencadeia, no setor das comunicações, consequências que incidem na economia política, entre outras áreas. A consequência na economia política está ligada à dissolução das fronteiras entre as telecomunicações, as mass media e a informática. É o surgimento da nova mídia numa onda mundial que vem promovendo a compra, fusões e parcerias de agentes econômicos. Esse fato vem promovendo uma concentração sem precedentes na mídia privada, promovendo o surgimento de novos mega-atores internacionais. "Esses atores se transformam em 'global players', interferindo direta ou indiretamente na formulação das políticas públicas de comunicações, tanto em nível internacional com em nível nacional." (Capparelli \& Lima, 2004, p. 17).

A Organização Mundial do Comércio (OMC) e a União Internacional de Telecomunicações (UIT) têm tido um papel preponderante no setor, uma vez que oferecem cobertura diplomática e de poder daqueles Estados nacionais que detêm hegemonia no mundo. A desregulamentação do setor tem significado, na prática, a reformulação das legislações nacionais, possibilitando, parcial ou totalmente, a abertura dos mercados ao capital nacional ou internacional e a consequente privatização das empresas estatais de comunicação, desqualificando inclusive o Estado nacional como gestor da atividade pública.

Os novos atores globais emergidos na mundialização já estão presentes no país desde o governo Sarney (1985-1989), quando foi tratada a regulamentação das TVs por assinatura, e, ainda, pelo governo Fernando Henrique Cardoso (1995-2002), com a regulamentação da TV a cabo, por satélite e as normas legais para a telefonia celular e fixa. Capparelli e Lima (2004) chamam a atenção para o argumento de que tais governos trataram a questão como se fosse uma "sinergia natural e inevitável", e não uma oligopolização no setor.

As comunicações apareceram como um dos setores de maior concentração econômica no país, fruto de uma série de aquisições e de fusões, estando ao lado de indústrias como as de chocolate, bebidas e pasta de dente. As megaempresas de comunicações encontraram no Brasil condições promissoras, decorrentes da frágil legislação, que ainda não delimita e/ou limita a concentração de propriedade. Não há normas ou restrições para a "afiliação" de emissoras de radiodifusão e nem um período

\footnotetext{
77 "Por tríade, entenda-se os grandes pólos da economia mundial, que se constituem em torno dos EUA, Alemanha e Japão" (Behring, 2003, p. 42).
} 
de carência para a troca legal de proprietários, sendo que, para as concessões de radiodifusão, é previsto um período de apenas cinco anos. Na comunicação brasileira persistem quatro peculiaridades: 1) a propriedade familiar; 2) a vinculação da radiodifusão com as elites políticas; 3) a presença das igrejas; 4) a exclusão do cidadão no processo de formulação e deliberação das políticas públicas para o setor.

A era Lula (2003-2010), em que pese a criação da Secretaria das Telecomunicações, os questionamentos quanto ao papel da Anatel e a realização da primeira Conferência Nacional de Comunicação (I Confecom), em 2009, com a participação de 1.600 delegados, representando os movimentos populares, o empresariado e o governo, deliberando mais de 600 resoluções, não propiciou mudanças significativas para uma democratização dos meios de comunicação em decorrência da pressão de organismos internacionais e grupos econômicos poderosos.

De acordo com Napolitano (2011), dos sete artigos constitucionais, apenas três foram regulamentados e efetivados até esse momento do governo Dilma. Foram regulados: a Lei $n^{\circ} 9.294 / 96$ que regula o artigo 220 , paragrafo $4^{\circ}$ e dispõe sobre a propaganda comercial de tabaco, bebidas alcoólicas, agrotóxicos, medicamentos e terapias; a Lei $\mathrm{n}^{\mathrm{o}}$ 10.610/2002 que disciplina sobre a participação de capital estrangeiro em empresas de comunicação; e a Lei $n^{\circ} 8.389 / 91$ que criou o Conselho de Comunicação Social.

Além disso, a ausência de regulação dos outros artigos da CF-88 tem produzido lacunas, uma vez que as leis anteriores a esse período estão em vigência, mas sendo alteradas e ajustadas à realidade das novas tecnologias e do mercado, produzindo, além de retrocessos, fragmentações e vazios, a exemplo do "Código Brasileiro de Telecomunicação de 1997 que tem validade parcial uma vez que somente diz respeito à radiodifusão sonora e de sons e imagens" (Napolitano, 2011, p. 9). Nesses últimos vinte e sete anos, foram alteradas as leis de imprensa (Lei $n^{\circ}$ 5.250/67), o Código Brasileiro de Telecomunicações (Lei $\mathrm{n}^{\mathrm{o}}$ 4.117/62) e o Decreto-lei que dispunha sobre a obrigatoriedade do diploma de jornalismo para o exercício profissional. Como afirma Gomes (2007, p. 156), “o fio de relações que determinam e condicionam quem pode ou não efetivamente exercer a comunicação ultrapassa a necessidade ontológica, e chega aos movimentos de dominação". Sem dúvida, essa ausência de interesse do legislativo brasileiro em regular as atividades econômicas relacionadas à comunicação social e a passividade do executivo do país estão relacionadas com a emergência e interesses de conglomerados transnacionais de comunicação como peças centrais no sistema global 
de comunicação e de difusão da informação, pelo impacto de novas tecnologias, especialmente aquelas associadas à comunicação via satélite, pelo fluxo assimétrico dos produtos de informação e de comunicação dentro do sistema global e pelas variações e desigualdades de acesso às redes de comunicação global, como apontou Thompson (1998).

Esse cenário da contrarreforma do Estado brasileiro e de afirmação do neoliberalismo com suas forças políticas em presença tem impedido a instituição da Comunicação Pública como meio e meta para o desenvolvimento da democracia. Embora, em países da América Latina, ${ }^{78}$ avanços em relação à regulação da comunicação tenham ocorrido, a conjuntura brasileira tem exigido articulações, organização e maior pressão por parte dos movimentos sociais. Na atualidade, além do fortalecimento do FNDC por meio de sua ampliação, considerando o ingresso de outras categorias profissionais, outras entidades se constituíram, a exemplo do Intervozes, além do engajamento de outros movimentos à luta pela democratização da comunicação, como, por exemplo, os movimentos que representam a questão racial, de gênero, de diversidade sexual, entre outros.

Em que pese o reconhecimento de que as alterações societárias decorrem da dinâmica entre as classes, a partir da perspectiva da dialética não se pode ignorar as particularidades e as mediações nos processos históricos. Nessa conjuntura, um campo que tem demandado reflexão sobre a Comunicação Pública é o universo das políticas públicas sociais. Sabe-se que esse direcionamento da investigação não se dá por acaso, visto que a configuração da segunda fase do neoliberalismo no Brasil investiu nas políticas sociais, em especial na Assistência Social como uma mediação para atenuar as expressões da questão social na atual fase do capitalismo. Dessa forma, alguns pesquisadores, em especial da área de comunicação, têm elaborado teoricamente a respeito da Comunicação Pública, revelando suas inúmeras possibilidades, como é o caso das produções na esfera pública estatal, referenciadas, em especial, nas experiências dos conselhos na área da Saúde. ${ }^{79}$

\footnotetext{
78 As referências mais recentes em relação à regulação e à democratização da comunicação ocorreram no Uruguai, em 2014, com a aprovação pelo congresso da Ley de Servicios de Comunicación Audiovisual, e na Argentina, em 2009, com a Ley de Medios, como ficou conhecida. Ambas se constituíram como um importante instrumento no combate aos monopólios e oligopólios de mídia, reafirmando a comunicação como um direito humano.

${ }^{79}$ No desenvolver da pesquisa bibliográfica para elaboração desta tese, vários artigos e teses foram consultados. Alguns tratavam da relação entre a Comunicação Pública e outras áreas das políticas públicas, em especial a Saúde. Mas importa destacar a contribuição do prof. Murilo Ramos (2005) sobre a necessidade de que a Comunicação Pública seja reconhecida enquanto política pública essencial, tal como
} 
Esse campo de investigação tem se referenciado na Comunicação Pública, tendo em vista a pertinência entre o direito às políticas sociais e o direito à comunicação. Embora a Comunicação Pública seja um conceito ainda em construção, esta advém no mesmo rastro do processo de redemocratização do país que possibilitou: a produção de alterações nas estruturas do Estado, das instituições privadas, do terceiro setor, além da pressão social pela implantação das políticas públicas sociais. Alguns pesquisadores brasileiros $^{80}$ tem se debruçado na perspectiva de compreender e definir o conceito de Comunicação Pública, dialogando inclusive com autores no exterior do país. No geral, há um reconhecimento de que a comunicação nas instituições públicas, estatais ou não, deve estabelecer uma interlocução ativa com o receptor, não devendo, portanto, contentar-se com os princípios utilizados no mercado de produtos ou no marketing, e sim articulados ao espírito da publicidade. De acordo com Duarte (2009, p. 60), o interesse recente dos comunicadores que atuam nos três poderes tem reconhecido a Comunicação Pública na atualidade como:

uma expressão que não especifica um conjunto de conhecimentos, áreas, profissões ou estruturas estando mais próximo de se caracterizar como um etos, uma postura de perceber e utilizar a comunicação como um instrumento de interesse coletivo para fortalecimento da cidadania.

Ao longo dos anos, uma tendência à elaboração do conceito tem sido a de relacionar a Comunicação Pública à concepção de esfera pública desenvolvida por Habermas, na qual o público se manifesta e influencia as decisões das instituições por meio da ação comunicativa, que se dá no cotidiano na esfera pública, permitindo o desenvolvimento de "uma complexa rede de transações informais, expressivas e solidárias que ocorrem na esfera pública ou no espaço público de qualquer sociedade” (McQuail, 2012, p. 17 apud Koçouski, 2013, p. 42).

Especificamente no Brasil, considerando-se os apontamentos da CF-88 e o processo de redemocratização, há uma tendência em reconhecer que a Comunicação Pública se dá na esfera pública estatal por meio dos conselhos de políticas e de direitos, bem como na realização das conferências nacionais, estaduais e municipais relacionadas às políticas públicas sociais. Compreende-se que esses espaços permitem a inclusão de

políticas públicas para os segmentos de saúde, alimentação, saneamento, trabalho, segurança, entre outros.

${ }^{80}$ Ao longo da elaboração desta tese foram acessadas muitas publicações sobre Comunicação Pública. Sobre sua conceituação, destacam-se os livros: Comunicação Pública - Estado, mercado, sociedade e interesse público, organizado por Jorge Duarte, e o livro Comunicação Pública - interlocuções, interlocutores e perspectivas, organizado por Heloiza Matos, dentre outras publicações na Revista Organicom, em especial a edição de número 4, de 2006. 
minorias e instituições da sociedade civil no debate público com vistas ao debate e a soluções de interesse geral. Nessa perspectiva, a Comunicação Pública diz respeito a uma dinâmica de informações na esfera pública, que pode inclusive chegar ao seu destinatário final por meio de reinterpretações e ou mediações, mas que objetiva, no geral: informar, consultar, deliberar, negociar e corresponsabilizar os cidadãos e ou consumidores em assuntos sempre de interesse geral.

Nesse sentido, autores como Lópes (2003, p. 1 apud Koçouski, 2013, p. 45) consideram que a Comunicação Pública nasce da relação que existe entre comunicação e política, considerando que o público é aquilo que é de todos e que a política é a arte de construir consensos. Daí ser possível ela se constituir em algumas dimensões, inclusive as de caráter mobilizatório. No Brasil, a compreensão consensual é de que a Comunicação Pública é um conceito que tem sua origem na comunicação governamental, embora não se confunda com ela. Assim, as dimensões da Comunicação Pública no Brasil, em que pese algumas diferenciações de nomenclatura, diz respeito às possibilidades da Comunicação Pública quanto ao campo de atuação e atividade profissional dos profissionais de comunicação. De acordo com Brandão (2006), existem cinco áreas diferentes: a) conhecimentos e técnicas da área de comunicação organizacional; b) comunicação científica; c) comunicação política; d) comunicação da sociedade civil organizada; e) comunicação do Estado e/ou governamental. Apresentaremos tais áreas a seguir, tendo a autora citada como a referência inicial.

A Comunicação Organizacional tem relação com a rede, fluxos, processos presentes nas organizações privadas como empresas, terceiro setor e sociedade em geral, estando, portanto, presente em todas as modalidades da Comunicação Pública constituindo um mix denominado por Kunsch (2013, p. 8) de "comunicação organizacional integrada". A Comunicação Pública tem por característica precípua o interesse público, o que ocorre no âmbito das organizações quando interage e dissemina informações de interesse geral.

A Comunicação Cientifica envolve muitas atividades e estudos, sendo o principal objetivo criar canais de integração da ciência com a vida cotidiana. Nesse sentido, a comunicação e a divulgação científica utilizam um variado leque de metodologias e tecnologias com vistas a influir para a mudança de hábitos de segmentos da população, bem como em decisões políticas da área.

Sobre a Comunicação Política, o entendimento é que existem dois enfoques nessa área: um que diz respeito às pesquisas de opinião pública com vistas a influenciar 
a vida política dos Estados e outra que diz respeito às disputas de interesses na regulação do setor das comunicações. A compreensão da Comunicação política como Comunicação Pública decorre principalmente em virtude da responsabilidade do Estado no seu papel de gerir as complexas questões sobre políticas públicas de comunicação e telecomunicação, assegurando, assim, o interesse o público em detrimento dos interesses privados e a liberdade de expressão dos profissionais que atuam no setor. De acordo com Matos (2006, p. 72), é preciso reconhecer que a "comunicação pública contém a comunicação política, e não o seu inverso", uma vez que o contexto atual exige uma perspectiva de totalidade, haja vista as disputas de poder marcadas pela centralidade da mídia e pelas transformações tecnológicas e no mercado, colaborando, inclusive, para o deslocamento progressivo do polo público-cidadão para o polo público-consumidor.

A respeito da comunicação da sociedade civil organizada, a literatura da área aponta que as mudanças ocorridas tanto na estrutura do Estado quanto no desenvolvimento das novas tecnologias tem possibilitado ao terceiro setor, aos movimentos sociais e às comunidades organizadas, entre outros, desenvolverem uma comunicação comunitária ou alternativa. De acordo com Peruzzo (2007, p. 27), o direito à comunicação não se refere apenas ao direito de ser informado sobre o conhecimento produzido pela humanidade: diz respeito também ao acesso de poder se comunicar. Ou seja, ao cidadão e às suas organizações deve ser assegurado "o direito de ascender aos canais de informação e comunicação como o rádio, televisão, internet, autofalantes e etc, enquanto emissores de conteúdos, com liberdade e poder de decisão sobre o que é veiculado". Trata-se, de acordo com Ruiz (2010), da relação que o direito de comunicação tem de não só produzir e veicular a informação, mas também de se ter asseguradas as condições técnicas e materiais para dizer e ser ouvido, entendendo que a comunicação pertence a toda a sociedade, configurando-se, portanto, como um bem público.

A Comunicação Pública como Comunicação do Estado e ou governamental ou ainda como sugere Duarte (2009, p. 59) como "Comunicação do Serviço Público" é compreendida como aquela de "responsabilidade do Estado e do governo e cujo objetivo deve ser de estabelecer um fluxo informativo e comunicativo com os cidadãos" (Brandão, 2006, p. 5), promovendo uma comunicação cuja informação deve se dar como um meio de construção da cidadania, no afloramento do sentimento de pertencer ao coletivo e de tomada de consciência do cidadão enquanto sujeito, visto sê-lo 
contribuinte, eleitor, usuário e outros. Segundo Matos (2009b), é recorrente uma confusão estabelecida entre as noções de comunicação governamental e Comunicação Pública, embora, para Zémor (2005), seja delicado estabelecer a fronteira entre Comunicação Pública, política e governamental porque o tempo de uma instituição pública é maior do que o tempo de exercício de poder de quem ocupa um cargo político ou um mandato eleitoral, sendo o cidadão também eleitor e por ser no legislativo onde acontecem os debates públicos em decorrência de sua própria natureza. No entanto, há um esforço de alguns autores em estabelecer essa diferenciação, bem como definir as interseções, uma vez que compreendem, assim como Matos e Gil (2013, p. 100), que a Comunicação Pública está comprometida com a

recuperação da esfera publica em sua força expressiva e democrática de permitir a interpelação do Estado e o direcionamento da política conforme o interesse coletivo [...] Por isso é fundamental desprender as amarras estatais, ou seja inseri-la efetivamente na esfera pública, entendida como um domínio da nossa vida pessoal.

Brandão (2009) e Matos (2009b) consideram que a Comunicação Pública se relaciona mais profundamente com as noções de cidadania, participação e engajamento cívico e dá origem aos processos de interlocução que ocorrem na esfera pública entre Estado, governo e sociedade, por meio dos quais temas de interesse coletivo e interesses plurais são discutidos e negociados. "É a ênfase do dissenso produtivo que permite à Comunicação Pública descortinar os contextos de negociação e conflito que subjazem à comunicação governamental” (Matos, 2009b, p. 1). Nessa perspectiva, a Comunicação de Governo está relacionada "à prática instrumental dos governos, em busca de legitimação da gestão estatal" (Matos \& Gil, 2013, p. 100).

Brandão (2009, p. 15) afirma que, em geral, os pesquisadores sobre Comunicação Pública têm tido um cuidado extremo em diferenciar a Comunicação Pública da comunicação de governo e que existem poucos estudos que aprofundem acerca da comunicação governamental, sendo "ainda mais pitoresco é saber que esta multiplicidade de visão está fundamentada em um mesmo autor que é Pierre Zémor". Matos (2009b), por sua vez, afirma que há um reconhecimento, entre autores brasileiros e franceses, de que entre a Comunicação Pública e a comunicação de governo existem pontos de interseção. Para essa autora, a comunicação de governo funciona como um elemento estratégico de mediação entre os sujeitos sociais e o governo, tendo, assim, o Estado um papel anunciante. No entanto, esse papel seria questionável tendo vista os interesses políticos do próprio governo em se projetar e influenciar os comportamentos 
e as atitudes dos cidadãos. Outros autores, a exemplo de Mégard e Deljarrie (2003 apud Matos, 2009b, p. 3), compreendem que a comunicação de governo visa organizar e publicizar informações que possibilitam a criação e o reforço aos vínculos entre os parceiros da ação pública.

Matos (2009a) considera ainda que a comunicação de governo pode contribuir para o fortalecimento do debate público, sem, contudo, haver mudanças no status dos cidadãos, visto que, de acordo com Brandão (2009), a Comunicação Pública identificada como ação governamental teria de desenvolver ações voltadas para a cidadania, as quais não ocorreriam por meio do embate argumentativo, mas por meio de quatro ações. Seriam elas: i) campanhas ligadas aos direitos dos cidadãos vinculados ao direito à assistência social, moradia, saúde e empregos, que devem despertar o sentimento cívico e a noção de cidadania; ii) campanhas de prevenção social voltadas para a higiene, segurança, educação e outros que objetivam mudanças de comportamento e de compreensões da realidade; iii) convocação dos cidadãos para o cumprimento de seus deveres, tais como alistamento militar, declaração de imposto de renda, entre outros; iv) realização de campanhas para melhorar a imagem pública do próprio governo.

Ainda de acordo com Matos (2009a; 2013), mudar o status dos cidadãos envolve mais que estratégias de convencimento, publicização de fatos e regulação social. É necessário o investimento no diálogo e na busca coletiva pelo entendimento, com vistas a soluções de questões de interesse público. Daí ser necessário compreender que a Comunicação Pública é muito mais que uma relação entre o governo e o povo, competindo a este assegurar os meios que favoreçam relações democráticas e inclusivas entre o Estado e a sociedade. Dessa forma, compreende-se que o Estado é o único, entre os demais sujeitos (promotores ou emissores) envoltos nas dimensões da Comunicação Pública, que age pelo dever de informar, uma vez que é no âmbito estatal que ocorre o reconhecimento do direito do cidadão e no qual deve estar assegurado o princípio da impessoalidade (Kçouski, 2013; Matos 2009a). Trata-se de um princípio constitucional (CF-88. Artigo 37) em que se deve excluir a promoção de autoridades ou servidores públicos, partidos políticos, entre outros, sobre as realizações administrativas. Nesse sentido, entende-se ser uma característica intrínseca a esse campo de atuação da Comunicação Pública a dimensão ética comprometida com o interesse público, "sem a qual ela deixa de existir enquanto conceito" (Kçouski, 2013, p. 54). 
Outro aspecto que também requer um aprofundamento nessa dimensão diz respeito à comunicação normativa, na qual se torna impensável a relação de troca entre Estado e cidadãos sem que estes últimos não compreendam as leis. Haswani (2013) aponta que, no Brasil, o caráter patrimonialista do estamento burocrático sempre privilegiou as classes dominantes desde o período colonial. A autora contribui com a ideia de que, ao longo da história do Brasil, a cúpula do poder sempre privilegiou e apadrinhou seus pares com cargos e vantagens, sendo que muitos desses apadrinhados vinham de universidades europeias, o que propiciou a criação de mecanismos de organização e controle da sociedade de forma a demonstrar a superioridade e o poder dos governantes, considerando-se o discurso rebuscado, com palavras incompreensíveis para uma massa de analfabetos e iletrados. Essa prática de elaborar os documentos administrativos não em função do destinatário final adentrou a cultura política brasileira, comprometendo o exercício democrático, dado que o conhecimento e a compreensão das leis são a base da Comunicação Pública e pré-condição para uma relação consciente entre o Estado e o cidadão. A Comunicação Pública, portanto, deve atuar para reduzir as diferenças de compreensão da realidade promovida historicamente pela desigualdade social com o apoio de uma comunicação governamental elitista e centralizadora.

Para Matos (2006) e Brandão (2009, p. 9) existe, entre tantas compreensões, um ponto comum no entendimento sobre a Comunicação Pública: a de que ela se refere a um "processo comunicativo que se instaura entre o Estado, o governo e a sociedade, com o objetivo de informar para a construção da cidadania”. Koçouski (2013) colabora com a compreensão de que a Comunicação Pública ocorre quando há o reconhecimento pelo agente de prestar um atendimento em que esteja assegurado o direito do cidadão à informação e à participação em assuntos relevantes à condição humana ou na vida em sociedade de forma a colaborar para que o debate se desenvolva até o nível de negociações e construção de consensos. Dessa forma, a Comunicação Pública pode ser identificada não só no âmbito do controle social como também no cotidiano das políticas sociais, uma vez que parte do controle social é representado pelos usuários dos serviços, a exemplo do Conselho Nacional e alguns conselhos estaduais e municipais da Assistência Social.

No campo da prestação de serviços ao cidadão por meio das políticas públicas sociais ocorrem processos comunicativos entre o Estado e o cidadão, mediados por agentes públicos estruturados e organizados sob diretrizes técnico-ético-políticas que 
podem estar coadunados ou não com os princípios da Comunicação Pública. De qualquer forma, trata-se de um espaço público constituído por fluxos de informação e interação entre agentes públicos e sujeitos sociais mediados pelo interesse geral. Nesse sentido, importa reconhecer que a Comunicação Pública, embora ocorra em um vasto campo e sua conceituação ainda ser um desafio, é realidade, sendo possível identificá-la a partir de sua singularidade e de suas formas como apresentado a seguir.

\subsection{Comunicação Pública: tipos, singularidades e as formas de sua prática}

Com base na compreensão de que a Comunicação Pública apresenta muitas possibilidades de atuação numa sociedade democrática, é preciso identificar suas características especificas na esfera pública estatal, uma vez que, de acordo com Zémor (2009), todo poder público civilizado acumula dados que estão ligados à sua identidade e ao seu desenvolvimento, sendo de sua competência disponibilizar as informações, fornecer as regras do jogo coletivo e prestar conta por seus atos. Nesse sentido, importa elencar os tipos de informações existentes na esfera pública estatal, de forma a relacioná-los com a singularidade das mensagens da Comunicação Pública, as quais devem resultar em transparência e na centralidade no cidadão, com vistas a uma relação dialógica, e não apenas de transmissão.

Segundo Duarte (2009), é possível agrupar as informações do Estado por tipos da seguinte forma: a) institucional: refere-se às informações que orientam sobre a estrutura, atribuições e funcionamento das instituições, além dos direitos e deveres; b) gestão: refere-se às informações que indicam as decisões e as ações de agentes que atuam em temas de interesse público; c) de utilidade pública: diz respeito às informações que estão relacionadas ao dia a dia das pessoas; d) de prestação de contas: diz respeito à apresentação e aos esclarecimentos sobre decisões políticas e sobre o uso de recursos públicos; e) de interesse privado: são informações que dizem respeito exclusivamente ao cidadão ou às instituições privadas; f) mercadológicos: referem-se a produtos e serviços que participam de concorrências no mercado; g) dados públicos: diz respeito à informação de dados produzidos pelo Estado e que dizem respeito à coletividade como as leis, as normas, os estudos e as estatísticas.

Identificados os tipos de informação importa destacar as características das mensagens da Comunicação Pública de forma a evidenciar sua singularidade em relação as outras formas de comunicação. Sendo assim, a primeira característica singular da 
mensagem da Comunicação Pública está relacionada em ser de interesse geral, compreendido como aquele decorrente de negociações, de alianças e de conflitos sociais, estando o interesse coletivo acima do interesse privado ou particular. Nesse sentido, a transparência é um pressuposto historicamente relacionado com a visibilidade e com a legitimidade e que, de acordo com Duarte (2009, p. 60), diz respeito,

à atuação ética, responsável, límpida e acessível no trato das questões de
interesse público. Exige a oferta de informações necessárias aos interessados,
o estímulo ao acesso, facilitação da fiscalização sobre as práticas de quem
detém o poder, adoção de mecanismos de cobrança de responsabilidade e
sistemática prestação de contas.

Uma segunda característica da mensagem da Comunicação Pública é centralizar o processo no cidadão, reconhecendo, como apontou Zémor (2005), tratar-se de um sujeito que é concomitantemente consumidor, eleitor e usuário das políticas públicas. Portanto, a democracia no poder de comunicar é condição para o exercício da cidadania, devendo o Estado assegurar as condições que possibilitem, conforme indicou Peruzzo (2004): o direito à liberdade de opinião; à liberdade de expressão; à liberdade de difusão; à liberdade de informação; e ao acesso e uso dos meios de comunicação e das tecnologias da informação e comunicação. A terceira característica da mensagem da Comunicação Pública tem a ver com o entendimento de que a comunicação é um processo maior do que informar. Vários autores que abordam esse tema destacam essa questão, uma vez que historicamente a transmissão tem adquirido ares de informação e de comunicação. Trata-se de assegurar a superação da concepção da passividade do receptor em relação ao emissor, sem, contudo, ignorar que a informação é o início do processo de conhecimento e que, ao se dar pelo viés da comunicação a junção da informação e interação, é assegurada, sendo o diálogo a essência desse processo. Monteiro (2009, p. 40) colabora com a ideia de que as informações que constituem a essência da Comunicação Pública só têm efeitos em longo prazo, uma vez que o resultado a que se pretende chegar "requer um tempo maior para se consolidar, já que seu objetivo, além de informar, é qualificar o cidadão para exercer seu direito de voz, de voto e de veto nas questões que dizem respeito à coletividade”. Outra característica da Comunicação Pública, mas que diz respeito às condições para a sua atuação tem relação, de acordo com Duarte (2009), com a adaptação dos instrumentos às necessidades, possibilidades e interesses dos públicos. Ou seja, em se tratando do espaço público estatal, o Estado, propulsor do processo comunicativo, deve viabilizar as condições para o exercício do direito coletivo e individual, à informação e à expressão 
por meio do diálogo, respeitando as particularidades e as necessidades, bem como o estímulo ao protagonismo dos sujeitos. Nesse sentido, deve-se buscar uma diferenciação entre os instrumentos de informação que são destinados a subsidiar, disponibilizar e fornecer dados em relação àqueles que propiciam relações dialógicas, a compreensão mutua de determinadas situações, acordos, consensos e encaminhamentos de questões decididas em comum acordo. Esses instrumentos de comunicação na perspectiva dialógica, de acordo com o autor, podem ser realizados a partir de três modelos básicos: i) os massivos, caracterizados pela disseminação de informação para um máximo de pessoas, sendo sua principal vantagem a possibilidade de se criar uma agenda com debates públicos. ii) os segmentados, orientado para grupos de interesse específico em que há maior possibilidade de domínio do conteúdo, do acesso, da distribuição e do retorno deles próprios. iii) os diretos referem-se ao contato personalizado, geralmente do tipo face a face e que pode ser ajustado imediatamente às características dos interlocutores. De acordo com o autor, "este instrumento garante uma aprendizagem mais consistente e um nível de informação adaptado às necessidades do interessado, assim como o feedback tende a ser mais imediato e preciso" (Duarte, 2009, p. 66). Por fim, outra condição à Comunicação Pública apontada por Duarte (2009) diz respeito à compreensão da comunicação como algo complexo e que deve ser tratada como um todo. Ou seja, deve-se levar em conta que tudo e todos em uma instituição pública se comunicam. Cada integrante, agente público, cartaz, uniforme, crachá, site e prédio, entre outros, transmitem informações e colaboram para que o cidadão acesse informações e forme sua opinião acerca dos processos políticos, econômicos e sociais.

Os cinco elementos destacados, que colaboram para elucidar a singularidade da Comunicação Pública, podem ser percebidos na compreensão de Zémor (2005; 2009) em relação à função da Comunicação Pública: i) informar (levar ao conhecimento, prestar conta e valorizar); ii) ouvir as demandas, as expectativas, as interrogações e o debate público; iii) contribuir para assegurar a relação social (sentimento de pertencimento ao coletivo, tomada de consciência do cidadão enquanto sujeito); iv) acompanhar as mudanças, tanto as comportamentais quanto as de organização social. Essas funções assumem variadas formas na prática da Comunicação Pública, considerando-se a vocação das instituições públicas, sendo que, no geral, devem: tornar a informação disponível ao público; assegurar o diálogo; dar visibilidade aos serviços; conduzir campanhas de informação; criar as condições para o debate público que acompanha os processos decisórios, entre outros, conforme indica Zémor (2009). 
Assim, na prática da Comunicação Pública pressupõem-se algumas condições e estruturas necessárias como:

\section{i) Criação de estruturas que organizem, que armazenem e que disponibilizem os dados para os usuários;}

O acesso à informação pública é um direito que deve ser assegurado. Para tal, é necessário que se criem estruturas para a organização, o armazenamento e o acesso. Todo documento é comunicável, devendo ser consultável gratuitamente ou cobrado, se for necessário, o preço de custo quando houver despesas para o poder público no caso de haver a necessidade de cópia. Na atualidade, o recurso à informática e às redes virtuais possibilita uma maior disponibilização dos dados, mas requer um reagrupamento das informações.

\section{ii) Recepção}

A recepção diz respeito ao início da relação com o usuário e com o serviço público. Assim, requer um investimento que vai desde a sinalização na cidade, dentro dos limites relativos à publicidade, às placas, às pré-placas indicativas do equipamento e à organização da logística dos locais de atendimento, como, por exemplo: mobiliário adequado; uniforme e crachás de identificação do servidor público; ações de formação dos servidores públicos; disponibilização de equipamentos multimídia com informações adequadas ao ambiente e à política; condições estruturais e gerenciais para redução de filas e/ou ampliação do atendimento, como, por exemplo, a alteração de horário de funcionamento mais adequado à demanda do usuário/comunidade, móveis mais adequados à recepção, dispositivos de fotocópia mais acessíveis, dentre outros.

\section{iii) Escuta}

A relação dos funcionários com o público em geral depende da aptidão do agente, que deve estar identificado por seu nome e sua função precisa. No entanto, é preciso identificar se a linguagem do agente público entra em ressonância com as preocupações, com a situação, com a cultura e com o vocabulário do usuário. Zémor (2009) considera que a simplicidade de expressão é um artifício para escapar à cultura e 
ao jargão administrativos. Para essa atividade, deve ser assegurada as condições ao atendimento, que tanto pode se dar de forma coletiva quanto individual. Essas escutas devem fornecer informações tanto para o poder público quanto para o usuário, substituindo, muitas vezes, de acordo com Zémor (2009), os microestudos contratados para a realização de reformas ou de mudanças, posto que as observações cotidianas das demandas contribuem tanto para a simplificação dos procedimentos e das estruturas como também para melhor resolutividade do atendimento.

\section{iv) Diálogo}

O diálogo é considerado como uma atitude de serviço público e exige um mediador qualificado, igualmente identificado, capaz de estabelecer relações entre a administração e o usuário, a fim de receber a demanda e qualificá-la, apontando as possibilidades de encaminhamentos. A escuta do caso particular confere ao cidadão a qualidade de contratante social junto ao poder público, mas também possibilita, por parte do agente público, o encorajamento à participação nos comitês de usuários, em associações e em outras instâncias representativas.

\section{v) Publicidade dos serviços oferecidos}

A publicidade dos serviços deve levar em consideração a variedade das situações dos receptores, tomando as devidas precauções na escolha da linguagem e da expressão publicitária, e ainda dos suportes e dos meios de comunicação. Deve atentar, também, para que sejam consideradas a qualidade e as condições em que estão ofertados antes de sua publicização.

\section{vi) Campanhas de informação de interesse geral}

As campanhas têm sua origem na utilidade pública e são instituídas e fixadas de acordo com o interesse da coletividade. A comunicação deve propor antídotos para banir ideias preconcebidas e os jargões para desenvolver a escuta social, multiplicar reportagens e todas as iniciativas que despertem o interesse dos cidadãos e das diversas instituições. Deve-se buscar motivar os cidadãos para que eles se associem ao processo de tomadas de decisão. 


\section{vii) Comunicação interna}

A Comunicação interna, entendida também como a identidade da instituição pública, deve assegurar a informação aos funcionários, escuta e diálogo interno, além de contribuir para formação permanente do quadro de profissionais. Orienta-se para que a escuta seja priorizada a fim de que se assegure as condições de trabalho dos funcionários, a mobilização e o estímulo com vistas à qualidade na ação e cumprimento dos objetivos do serviço público.

\section{viii) Valorização da política institucional}

Sobre a valorização da política institucional, Zémor (2009, p. 234) delega à comunicação institucional a atribuição de criar os meios para apresentar o papel do organismo, de afirmar sua identidade e sua imagem, de prestar contas do conjunto de suas atividades. Entende que a comunicação "só é dominada quando se assume as preocupações da comunicação externa e aquelas ligadas à comunicação interna". Nesse sentido, a identidade do organismo deve ser central à comunicação, uma vez que é por meio da identidade que se tem obtém a legitimidade e a coerência em relação a um lugar em relação aos outros. O imaginário organizacional, na concepção de Zémor, é fundado sobre três imagens internas: da instituição, pelos que a compõem; das qualidades éticas e profissionais que qualificam sua vocação e missão; e pelos grupos internos e externos que a influenciam. Assim, importa que a aproximação da identidade e da legitimidade assegurem a transparência e a autenticidade como uma regra fundamental da Comunicação Pública.

A compreensão sobre os tipos, singularidades das mensagens, das funções e das práticas da Comunicação Pública reafirma a possibilidade de ela ser percebida como parte do direito às políticas sociais, uma vez que são organismos de Estado e têm por objetivo a prestação de serviços diretos à população, sendo algumas delas universais, como, por exemplo, a política de Saúde, de Educação e outras para quem dela necessitar, como é o caso da Assistência Social destinada aos segmentos mais subalternizados da sociedade. Matos (2009) aponta a Comunicação Pública como um "modelo teórico-instrumental" e Sardinha (2012, p. 3) a indica como um "modelo 
teórico-operativo, um serviço público tão fundamental como são os serviços de saúde". Ou seja, estes autores indicam, ao pensarmos a Comunicação Pública no âmbito do espaço público que o Estado deve assegurar as condições para que o exercício do direito ao diálogo, à informação e expressão seja incorporado ao cotidiano dos serviços prestados, ampliando a perspectiva cidadã de minorias, como mulheres, negros, povos indígenas e outros. No entanto, com base nas categorias desenvolvidas até o momento e na afirmativa de Kçouski (2013, p. 54) de que uma característica intrínseca à Comunicação Pública na esfera estatal é sua dimensão ética comprometida com o interesse público, "sem a qual ela deixa de existir enquanto conceito" considera-se tratar de pensar a Comunicação Pública não como um modelo, tendo em vista que as relações sociais são dinâmicas, diferenciadas e históricas, mas como uma diretriz técnico-éticopolítica uma vez que em seu núcleo há o reconhecimento da liberdade como um valor central e o compromisso com uma transformação societária onde a autonomia e a emancipação dos indivíduos sociais sejam alcançadas. Ou seja, a Comunicação Pública requer uma unidade dialética entre a dimensão humana e a técnica da comunicação, conforme indicou Gomes (2007). Nesse sentido, importa a Comunicação Pública no serviço público estar submetida a exigências como: informar por dever; assegurar uma pedagogia às mensagens, incluir a comunicação em todo o processo de atendimento e, especialmente, contribuir para conferir sentido à vida coletiva. Assim, destacou-se neste capítulo todos os atributos da Comunicação Pública verificados e analisados a partir da pesquisa de campo, a qual será apresentada a seguir. 


\section{CAPÍTULO 5}

\section{Comunicação pública e Assistência Social: compatibilidades e contradições}

Este capítulo tem por objetivo, a partir dos dados coletados por meio das pesquisas de campo qualitativa e documental e das categorias analíticas, evidenciar a Comunicação Pública junto aos usuários nos Cras, desvendando as compatibilidades e as contradições existentes nesse processo comunicativo na Assistência Social.

Toda análise realizada neste capítulo se sustenta na observação das condições objetivas e subjetivas, como requer a dialética, buscando as determinações constitutivas da realidade, uma vez que o conhecimento do concreto se realiza ao envolver universalidade, particularidade e singularidade. Portanto, a perspectiva é estabelecer o todo e as partes com vistas a compreender a essência da comunicação junto aos usuários nos Cras na execução da política de Assistência Social. Para tal, subdividiu-se este capítulo em dois subcapítulos. O primeiro traça uma panorâmica da estrutura e dos serviços prestados ao usuário nos Cras e analisa a estrutura e o padrão do atendimento real, tendo como referência as normativas da política e a Comunicação Pública entendida como um todo, sendo o cidadão o princípio, o meio e o fim de toda a ação. $\mathrm{O}$ segundo subcapítulo aborda a comunicação nos Cras e está dividido em três blocos. $\mathrm{O}$ primeiro bloco analisa a totalidade da comunicação interna e externa da política de Assistência Social, a partir do olhar dos técnicos nos Cras e de outros dados e observações. O segundo bloco aborda como os técnicos organizam a comunicação junto aos usuários, e o terceiro bloco apresenta e analisa como os usuários percebem a política de Assistência Social.

Em relação à apresentação das entrevistas, optou-se por identificar os técnicos por sua condição na política e os usuários por número, destacando em ambos a localidade.

\subsection{O Cras e o atendimento ao usuário}

Este subcapítulo abordará os aspectos do atendimento prestado nos Cras, que é a porta de entrada do Suas e relacionado à proteção social básica, tendo como referência a infraestrutura, a logística e as concepções que perpassam na operacionalização dos serviços ofertados, uma vez que, para a Comunicação Pública, a comunicação é um todo. Tudo e todos em uma instituição pública comunicam, colaborando para que o 
cidadão acesse informações e forme sua opinião acerca dos processos políticos, econômicos e sociais (Duarte, 2009).

Para tanto, o primeiro aspecto a ser considerado tem relação com o espaço físico dos Cras, cuja atribuição de instalação do equipamento determinado pelo Suas é da prefeitura. De acordo com o Censo Suas/Cras 2014, 47,7\% dos imóveis destinados aos Cras são próprios da prefeitura, 44,8\% são alugados, $6 \%$ são cedidos e 1,4\% outros, sendo que $81,8 \%$ dos imóveis estão destinados apenas para o Cras.

Em relação à acessibilidade no equipamento em 46,9\% dos Cras o acesso principal é adaptado com rampas e rota acessível desde a calçada até a recepção. 49,4\% da rota aos espaços do Cras (recepção, salas de atendimento e espaços de uso coletivo) é acessível e $23,8 \%$ dos banheiros são adaptados para pessoas com deficiência, em que pese toda essa estrutura estar fora das normas da ABNT.

No entanto, o que se percebe pelas visitas, a exemplo do Cras Menino Jesus, em São Gabriel/RS, Cras Havaí/Ventosa, em Belo Horizonte/MG, Cras Ribeirinho (Foto 1) e Urumari, em Santarém/PA, é que, embora funcionem em equipamentos próprios da prefeitura, essas unidades foram adaptadas a partir de prédios construídos em décadas passadas, alguns inclusive tendo sido repassados para o município quando ocorreu a extinção da Legião Brasileira de Assistência (LBA), sendo ainda identificados pela comunidade como obra social ou como ocorreu em Belo Horizonte, onde uma usuária se referiu ao Cras como CAC. ${ }^{81}$ Há também aqueles, a exemplo do Cras Urumari, Santarém/PA, onde o equipamento era uma escola de ensino fundamental rural atualmente cedida para a Assistência Social. O único prédio construído com a finalidade de ser esse equipamento é o Cras Alto Vera Cruz, em Belo Horizonte/MG. Essa unidade possui todos os quesitos das normativas, inclusive elevador para as pessoas com mobilidade reduzida e portadoras de deficiência. De acordo com uma usuária desse equipamento, há uma maior credibilidade no serviço ao comparar com o espaço anterior.

\footnotetext{
${ }^{81}$ Em algumas regiões mais pobres de Belo Horizonte, por volta dos anos de 1980, foram construídos equipamentos denominado de Centro de Desenvolvimento Urbano. Neles, eram desenvolvidos trabalhos por meio da prefeitura e da LBA sendo as ações relacionadas ao combate da desnutrição infantil, atividades esportivas, entrega de cartão de leite, biblioteca, etc. No decorrer dos anos, alguns deles firmaram convênios com creches para utilização do espaço. Outros passaram a cobrar financeiramente a comunidade em decorrência dos serviços oferecidos, tais como atividades para os idosos, infraestrutura para times de futebol, entre outros. Outros, por sua vez, tornaram-se clube privado, como na região de Venda Nova. Em meados dos anos de 1990, com a Loas instituída, houve uma força-tarefa de iniciativa da área da Assistência Social para instituir um conselho comunitário local a fim de resgatar a função pública do equipamento que passou a ser denominado de CAC (Centro de Apoio Comunitário).
} 
Eu reparo em tudo. Reparo as maravilhas que tem, tudo arrumadinho, bonito. O de lá estava uma pindaíba danada (se referindo ao antigo Cras). Parecia casa de moradia. Aqui não, aqui tem salas bonitas, lá parecia um quarto, sala, copa, cozinha e banheiro. Aqui não. Aqui a gente vem para buscar a informação mesmo. Tudo dividido, bonitinho, dá até gosto a gente de vir cá. (Usuária 4, de Belo Horizonte)

Ainda sobre as condições do espaço físico, um conselheiro, representante dos usuários no CMAS de Belo Horizonte, disse: "o pessoal aluga uma casa e coloca o equipamento lá e as pessoas veem a placa e olham a prefeitura lá e acham que é uma regional $^{82}$ ou coisa assim". Essa é a situação dos equipamentos em Tobias Barreto/SE (Foto 2) e Rubiataba/GO que alugaram imóveis e adaptaram para o funcionamento do Cras. As normativas reconhecem que o aluguel de um imóvel seja a possibilidade imediata diante da necessidade de se implantar a política, mas chama a atenção para o cumprimento dos quesitos estabelecidos para a estrutura física e para o tempo de contrato, dado que a permanência do Cras em determinado local é importante para que se torne referência.

Em Rubiataba, onde há apenas um Cras fixo, a recepção foi adaptada na garagem do imóvel e não há sala para atendimento individual, sendo que as atividades coletivas, tais como as oficinas profissionalizantes, ocorrem em cômodos nos fundos da casa e no quintal. Os imóveis onde funcionam os Cras de Tobias Barreto são maiores, mas também adaptados. O Cras que atende a população rural é bem central e termina sendo um espaço mais administrativo, de resoluções mais pontuais, sendo o trabalho socioeducativo realizado de forma descentralizada em equipamentos de outras políticas na área rural.

\footnotetext{
${ }^{82}$ Trata-se, em Belo Horizonte, de um equipamento de administrativo.
} 


\section{Foto 1}

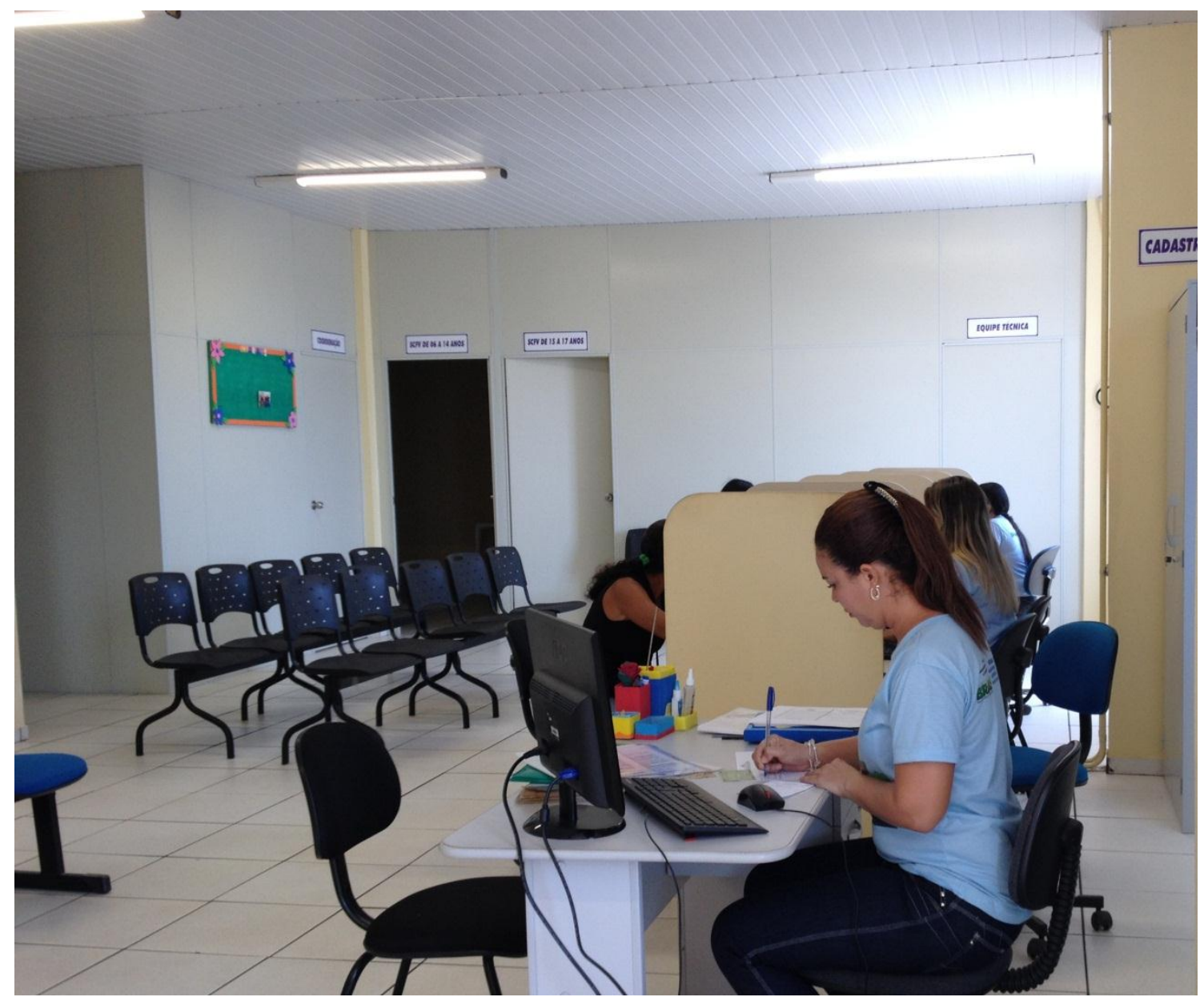

Recepção do Cras Ribeirinho onde também é realizado o cadastro no Programa Bolsa Família. Santarém/PA. Foto: Solange Albernaz. Acervo pessoal.

\section{Foto 2}

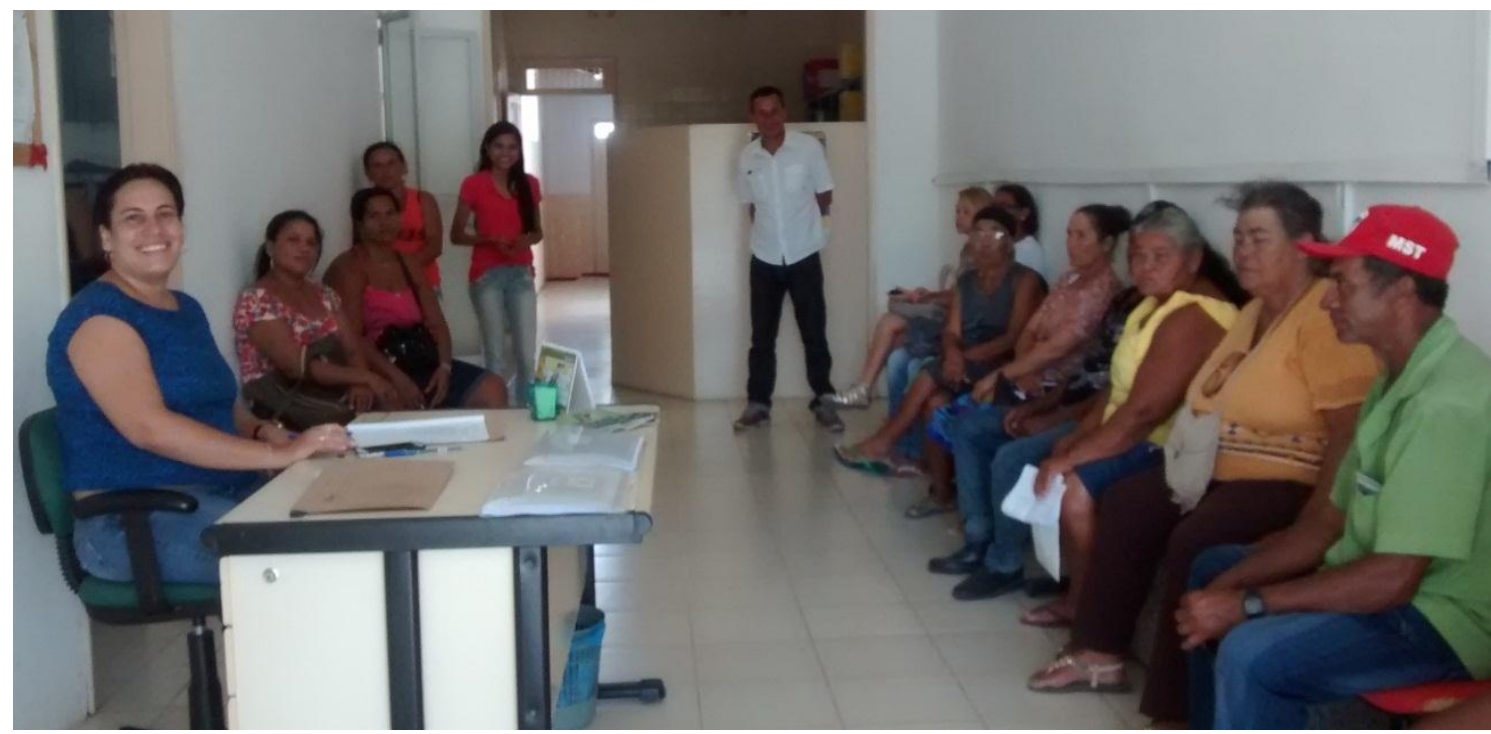

Recepção Cras II - Tobias Barreto/SE. Foto: Solange Albernaz. Acervo pessoal. 
Uma das características da singularidade da Comunicação Pública é que a comunicação precisa ser compreendida como um todo. Assim, Zémor (2009) considera que o equipamento público deve assegurar informação desde as placas de rua que indicam a localização da unidade até a sinalização no local, além de serem consideradas as condições de atendimento que levem em consideração as circunstâncias do usuário, assegurando-lhe instalações como banheiro, água, lanche, cadeiras adequados ao tempo de espera, sendo que o agente público deve estar devidamente identificado no atendimento e a recepção deve contar com móveis adequados e uma logística como: telefone, equipamento multimídia, dispositivos de fotocópia, entre outros.

Em relação ao espaço físico dos Cras, embora as normativas apontem sobre a estrutura ser reflexo de uma concepção, devendo expressar a cultura local, de forma a estimular a expressão e o sentimento de pertencimento das famílias usuárias, não foi encontrado uma identidade visual nos equipamentos que expressem essa direção. Os prédios próprios mantêm o padrão, no geral, dos prédios públicos dos anos de 1970/1980 (Foto 3), à exceção do Cras de Alto Vera Cruz, cuja construção é recente, e do Cras de Ribeirinho (Foto 4), que funciona em um prédio localizado na beira do porto, pintado com as cores do partido do prefeito, onde funcionam outros projetos sociais, estando previsto à época a instalação do restaurante popular.

\section{Foto 3}

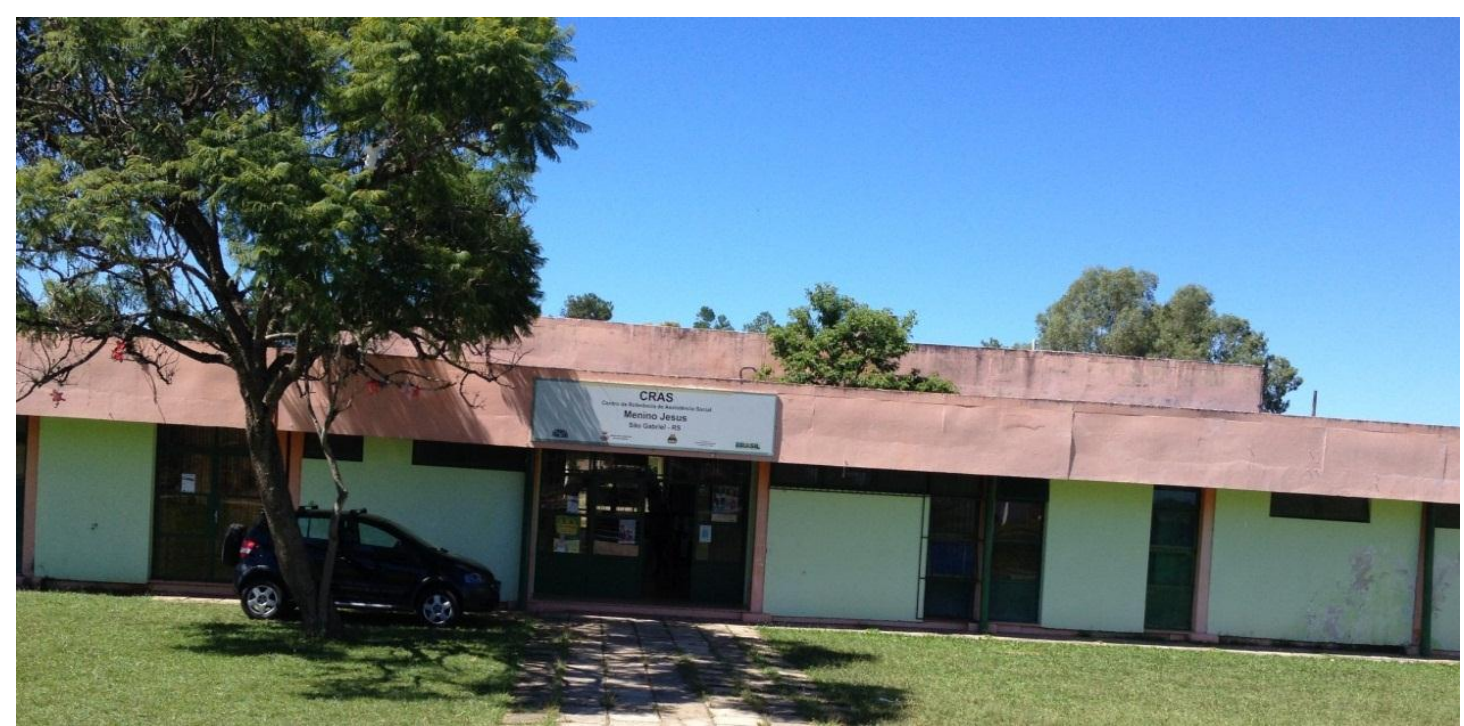

Faixada externa do Cras Menino Jesus. São Gabriel/RS. Foto: Solange Albernaz. Acervo pessoal. 


\section{Foto 4}

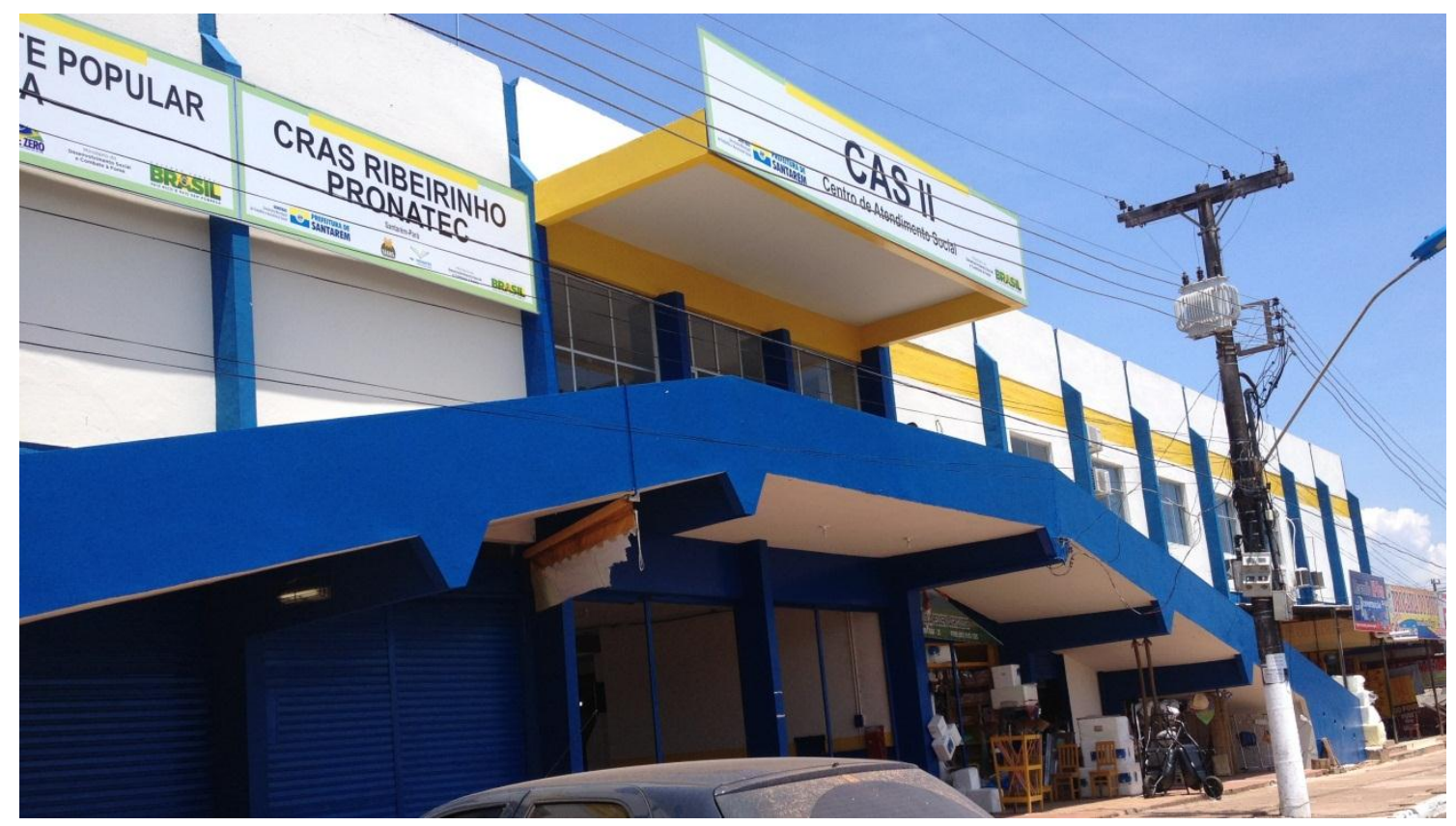

Faixada externa do Cras Ribeirinho. Santarém/PA. Foto: Solange Albernaz. Acervo pessoal.

Quanto à sinalização, em nenhum município visitado pôde-se observar placas pré-indicativas sobre o local. Todavia, em relação à sinalização de identificação no equipamento, todos os Cras visitados estão dentro das normas, com suas especificidades, a exemplo do Cras de Rubiataba/GO (Foto 5), cuja placa se encontra no muro lateral interno do imóvel. Em Belo Horizonte, no Cras de Havaí/Ventosa a placa de sinalização da unidade se encontra acima do portão que fica fechado, sendo que a entrada se dá por outro portão, cuja placa é referente a outros serviços e programas. Contudo, o Censo Suas/Cras 2014 indica que 85,1\% dos Cras possuem placa de sinalização do equipamento conforme o modelo padronizado pelo MDS (Foto 6) e 10,8\% em outro modelo, mas com o nome Centro de Referência de Assistência Social, conforme pode-se verificar na foto do Cras de Rubiataba/GO. 


\section{Foto 5}

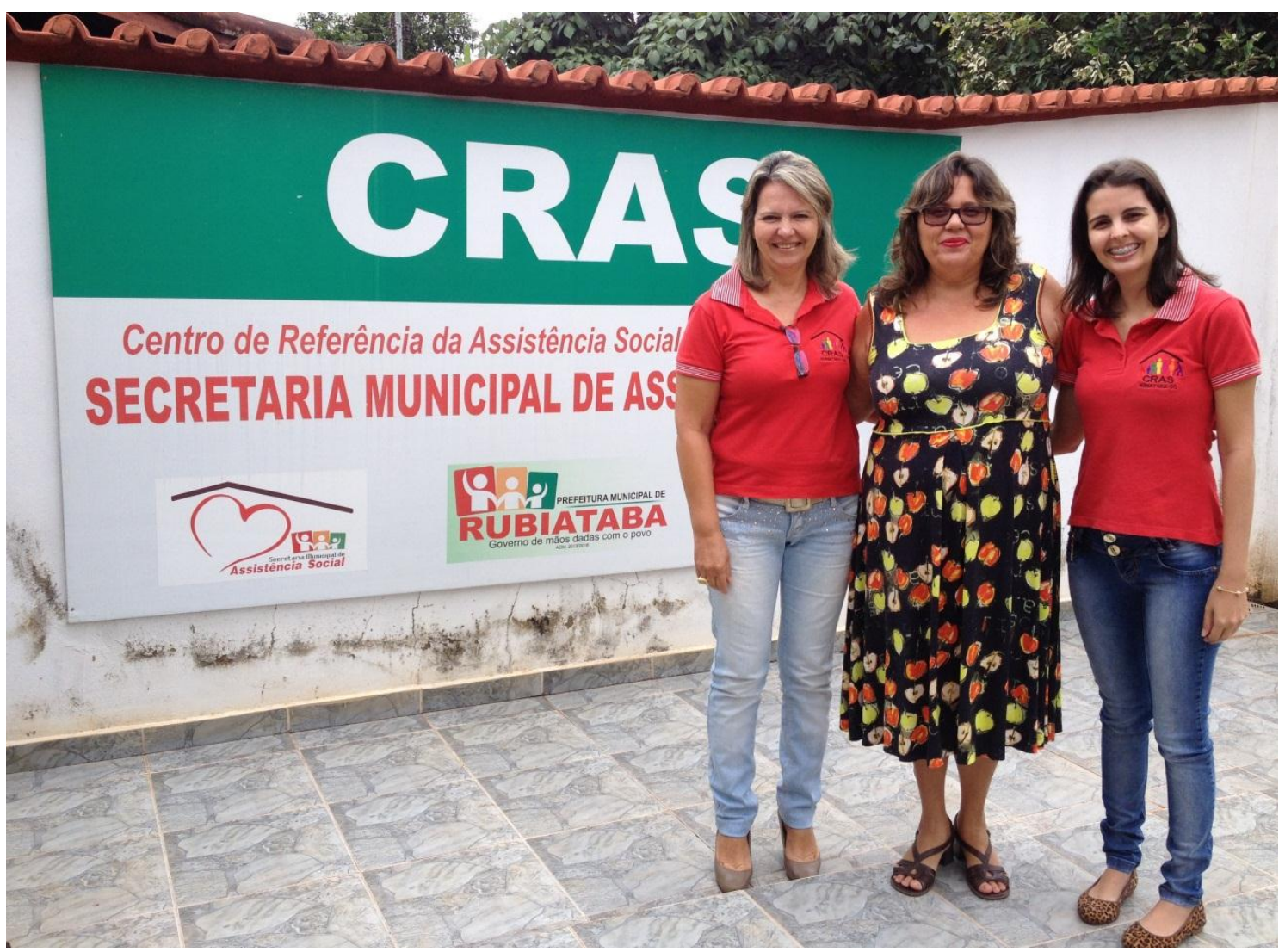

Identificação do equipamento no muro interno do Cras de Rubiataba/GO. Foto: Solange Albernaz. Acervo pessoal. 
Foto 6

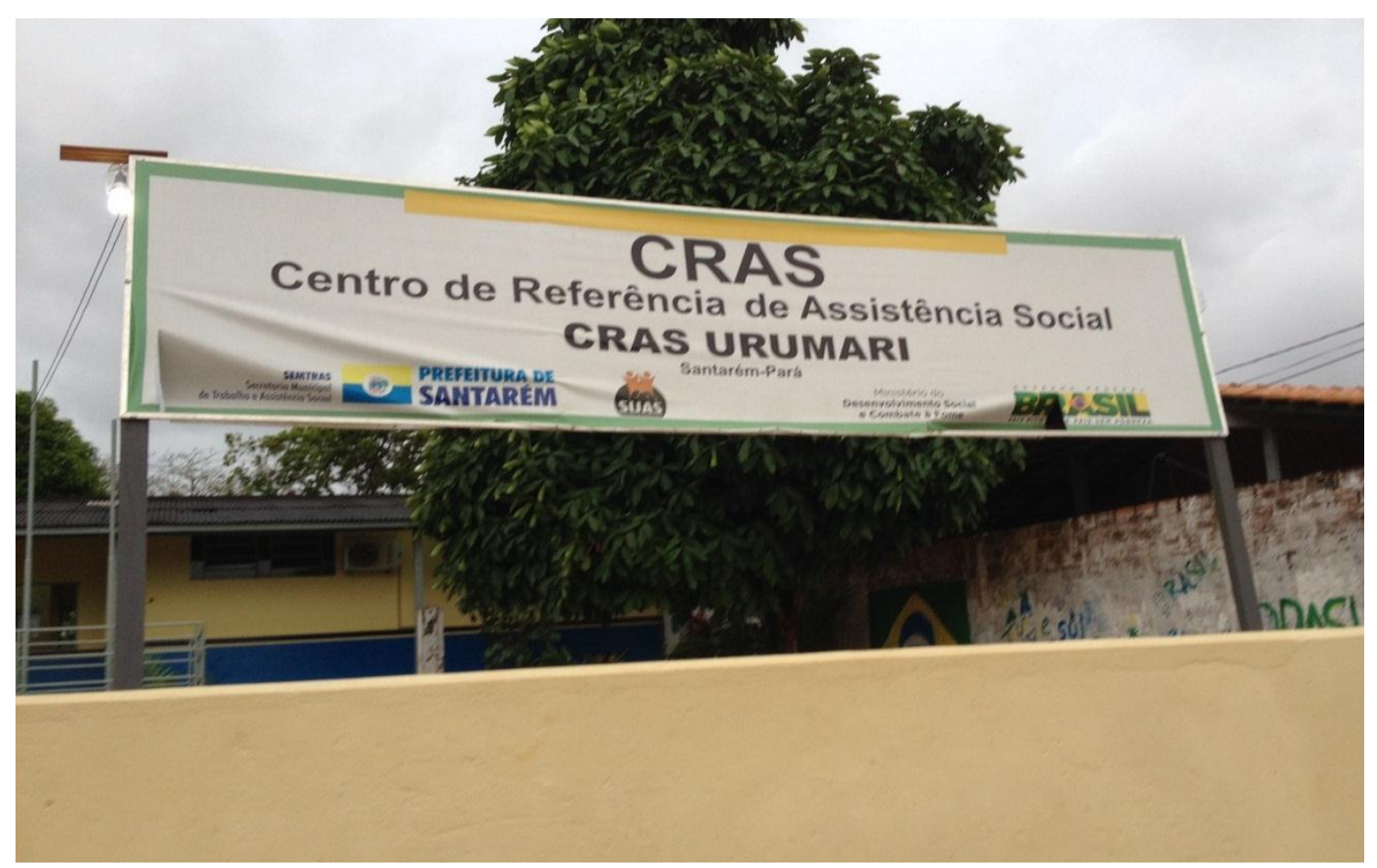

Placa de identificação do Cras Urumari de acordo com as normativas do MDS. Santarém/PA. Foto: Solange Albernaz. Acervo pessoal.

No Cras Ribeirinho, em Santarém/PA, ficam disponibilizados para os usuários, em uma mesa no canto da sala de recepção, água, café e biscoitos, pois ali funciona o cadastro do Programa Bolsa Família. Foi o único Cras em que se observou uma atenção para além das questões de infraestrutura relacionadas com as circunstâncias do usuário, como aponta Zémor (2009). No quesito identificação do agente público, não foi observado o uso de crachá, mas em quase todos os Cras há o uso de uniformes definido pela própria equipe. Em alguns Cras há variação na cor do tecido para indicar a atividade desempenhada pelo profissional. Em relação a equipamentos e materiais disponíveis para o desenvolvimento dos serviços no Cras, a pesquisa de campo permitiu identificar que a disponibilidade de linha para telefonia móvel, ${ }^{83}$ automóvel exclusivo para o Cras e acesso a internet constituem um problema para muitas unidades. Na região norte do país, a questão do acesso à internet tem também relação com uma particularidade regional, não se tratando apenas de uma especificidade do Cras. Essa precariedade em itens básicos de funcionamento contraria as orientações técnicas, que afirmam ser determinante que o Cras disponha de equipamentos e de condições de conectividade para agilidade dos processos de trabalho e maior interação com a rede

\footnotetext{
${ }^{83}$ O Censo Suas/Cras 2014 não apurou esse item.
} 
socioassistencial e setorial, bem como seja assegurado o automóvel por ser imprescindível aos serviços.

O Censo Suas/Cras 2014 constata que apenas 33,1\% possuem automóvel exclusivo para o Cras (Foto 7). Em relação ao número de computadores ligados a internet para uso da equipe técnica os dados indicam que 18,2\% dos Cras possuem 2 computadores, mas destes apenas 15,9 estão conectados à internet. Essa proporção entre computador e internet é uma variável constante entre a quantidade de computadores e quantos deles que estão ligados à internet, revelando a necessidade de investimento. $\mathrm{O}$ Censo Suas/Cras 2014 indica que 74,5\% dos Cras não possuem computador ligado à internet para uso do usuário, não sendo verificado essa possibilidade nos Cras visitados, exceto em Belo Horizonte, onde há uma sala no Cras de Alto Vera Cruz com cerca de vinte computadores novos destinados, a princípio, para cursos profissionalizantes, sendo a utilização em outros momentos facultada apenas com a presença de um monitor. Como a prefeitura não disponibiliza este profissional, os computadores ficam obsoletos e a comunidade sem acesso. 


\section{Foto 7}

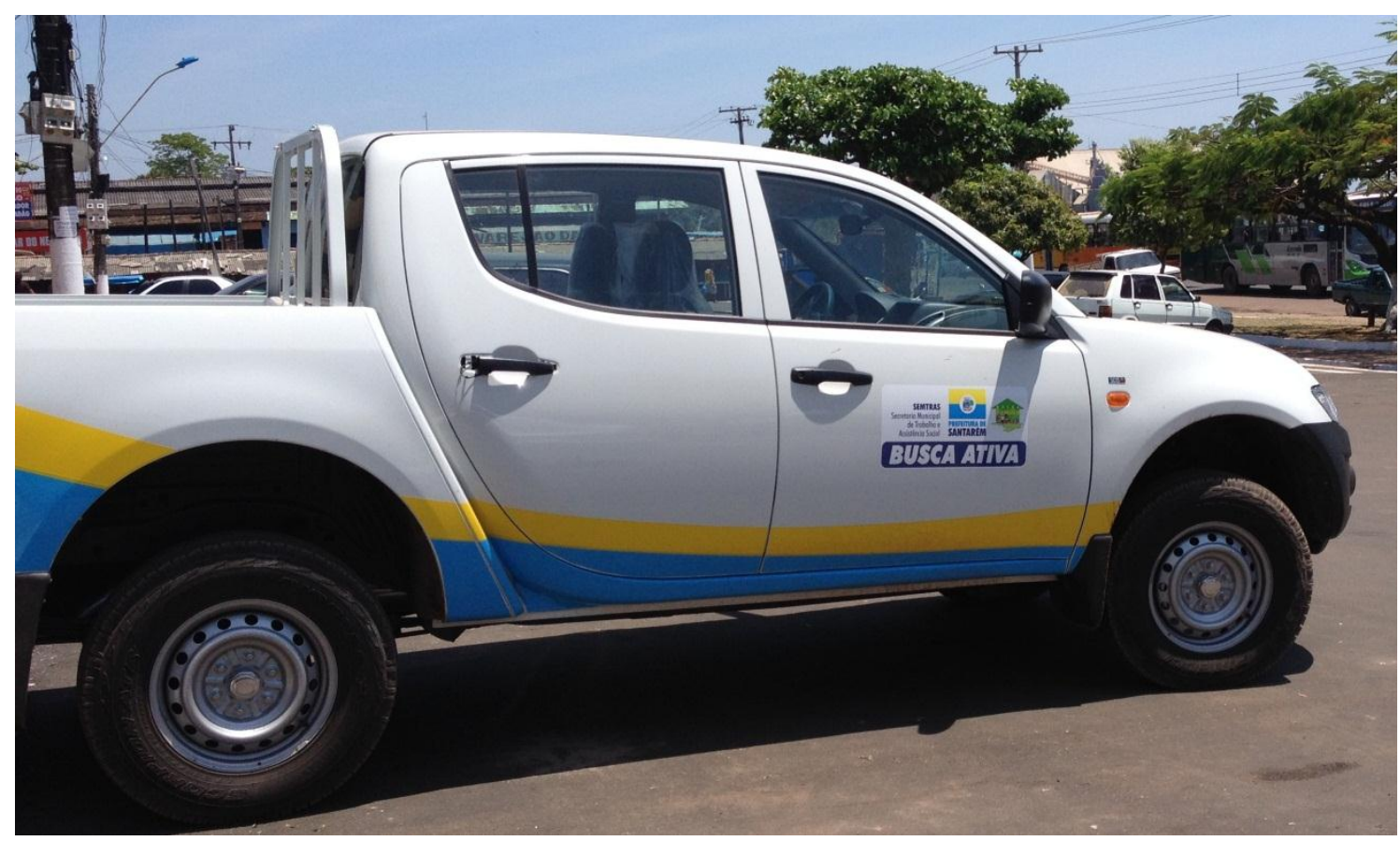

Automóvel da Proteção Social Básica compartilhado pelos Cras em Santarém/PA. Foto: Solange Albernaz. Acervo pessoal.

Os técnicos dos vários Cras visitados, em sua maioria, informaram usar o próprio celular para acionar o usuário, considerando-se a urgência da questão ou ainda por ser a única forma de contato. Também utilizam seus carros pessoais, uma vez que a disponibilidade de transporte para o serviço é reduzido, como explicitaram as técnicas de Belo Horizonte e Santarém, respectivamente.

[...] A gente fazia essas visitas domiciliares também a pé e hoje a gente tem um carro disponibilizado pela regional duas vezes por semana. (Técnica do Cras Alto Vera Cruz. Belo Horizonte/MG)

Infelizmente a gente não tem transporte próprio direcionado aqui. Tem na coordenação dos Cras. Direcionado, disponibilizado para as necessidades nossas dos Cras. (Técnica do Cras Urumari, Santarém/PA)

O que mais dificulta para nós no CRAS é a questão de transporte. Até mesmo a questão de a equipe estar no distrito. Mesmo até as assistentes sociais estarem nos fazendo uma visita temos carro duas vezes por semana. É uma demanda grande com pouco acesso. A gente usa muitos carros nossos particulares mesmo para estar ali no serviço. Cada um usa seu petróleo, seu carro. Graças a Deus com muita dificuldade a gente está caminhando. Os funcionários têm que ter mais transporte dentro das cidades também. (Técnica do Cras de Rubiataba/GO)

O Censo Suas/Cras 2014 revela ainda que $81 \%$ dos Cras possuem televisão, $85 \%$ possuem telefone, podendo este ser exclusivo ou compartilhado. 94,4\% possuem 
impressoras e 65,3\% DVD/Cassete. A maioria, conforme orienta as normativas, possui equipamentos multimídia, brinquedos e materiais pedagógicos, culturais e esportivos.

\begin{abstract}
A organização do espaço físico do CRAS deve considerar a diversidade do público que frequenta essa unidade socioassistencial, de modo a respeitar as especificidades de todos os membros das famílias: crianças pequenas, adolescentes, jovens e idosos, para que nenhum usuário do CRAS sinta-se alheio ao serviço ofertado, devido às características ambientais da unidade. Por exemplo, é importante que o CRAS possua mobiliários próprios para crianças e brinquedos à disposição, de forma a assegurar a acolhida delas, e possua cartazes que façam referência aos diferentes ciclos de vida da população e suas especificidades. (Orientações Técnicas: Centro de Referência de Assistência Social - CRAS, 2009, p. 55-56)
\end{abstract}

No entanto, por meio da observação, percebeu-se nos Cras, a exemplo de São Gabriel (Foto 8) e Tobias Barreto, que a televisão na recepção estava sintonizada em canais da rede aberta, reforçando os meios de comunicação que historicamente sempre se colocaram no campo oposto da assistência social como política pública e que atuam, muitas vezes, como porta-voz do preconceito contra os pobres. A TV e os DVD/Cassete seriam melhor aproveitados com mensagens de utilidade pública ou institucional, por meio do modelo de comunicação segmentado (Duarte, 2009), orientado para grupos de interesse específico, havendo mais possibilidades de domínio do conteúdo, de acesso, de distribuição e de retorno deles próprios, qualificando a relação do usuário com o equipamento e com a política.

\title{
Foto 8
}

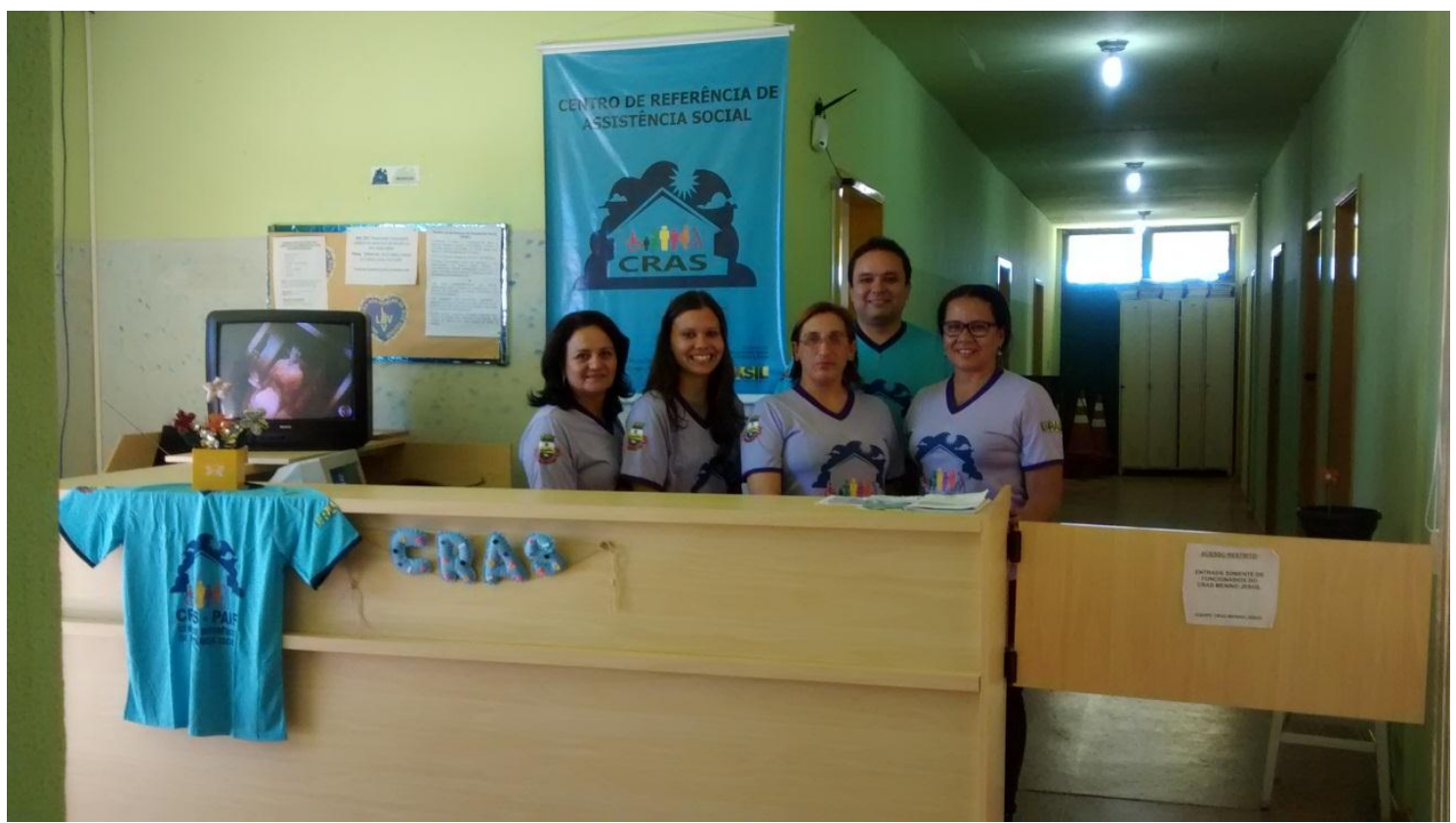

Recepção do Cras Menino Jesus com televisão e equipe uniformizada. São Gabriel/RS. Foto: Solange Albernaz. Acervo pessoal. 
Um serviço realizado por 65,1\% dos Cras é o Cadastro Único (CadÚnico). Ao ser inserido nesse cadastro, o cidadão passa a ser incluído em vários serviços e programas federais. ${ }^{84}$ Alguns Cras possuem uma ficha de Cadastro própria como uma estratégia inicial de abordagem. Nem todos os Cras realizam o cadastramento do Programa Bolsa Família, como Belo Horizonte e São Gabriel/RS. Alguns Cras preenchem o formulário manualmente e encaminham posteriormente para uma central por meio da qual os dados são lançados no sistema, como em Santarém/PA.

No primeiro atendimento, em geral, o usuário recebe o material de apresentação com informações do tipo institucional (Figuras 8 e 9) e uma lista, se necessário, feita de próprio punho pelo agente público de documentos necessários ao retorno. Em alguns Cras é entregue ainda um Cartão do Usuário (Figura10) com vistas à organização deste, mas também para o controle do Cras sobre a presença e a participação do usuário nos serviços oferecidos pelo Paif.

\section{Figura 8}

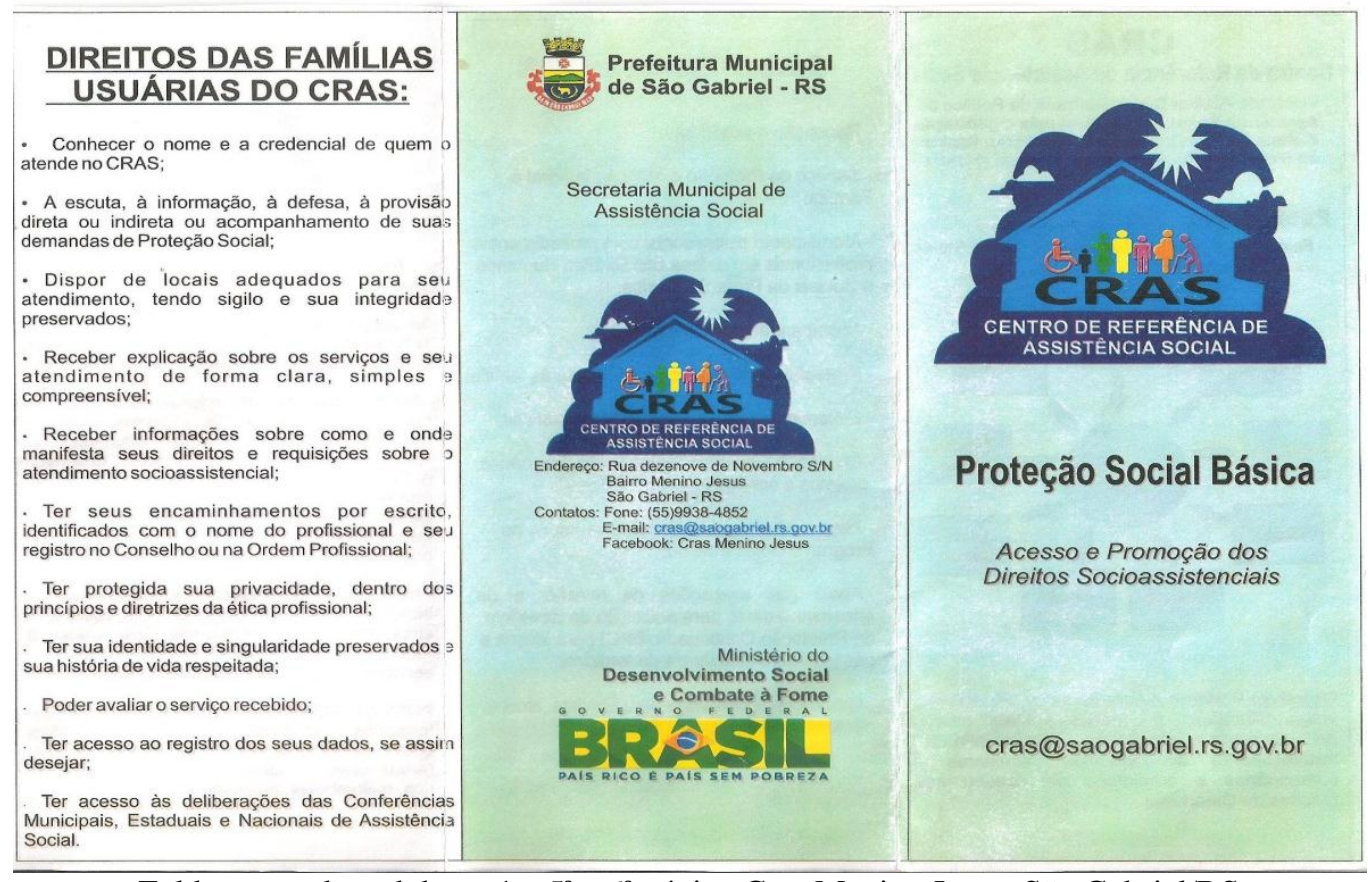

Folder, com duas dobras. 1a, $5^{\mathrm{a}}$ e $6^{\mathrm{a}}$ página Cras Menino Jesus. São Gabriel/RS

\footnotetext{
${ }^{84}$ O Cadastro Único faculta o acesso das pessoas aos seguintes programas e serviços: Bolsa Família; Tarifa Social de Energia Elétrica; Isenção de pagamento de taxa de inscrição em concursos públicos; ProJovem Adolescente; Programa de Erradicação do Trabalho Infantil (Peti); Programa Brasil Carinhoso; Carteira do Idoso; Programa Minha Casa Minha Vida e outros Programas Habitacionais do Ministério das Cidades; Passe Livre para pessoas com deficiência; e Carta Social. No entanto, estar cadastrado no CadÚnico não quer dizer ter acesso a todos esses benefícios.
} 


\section{Figura 9}

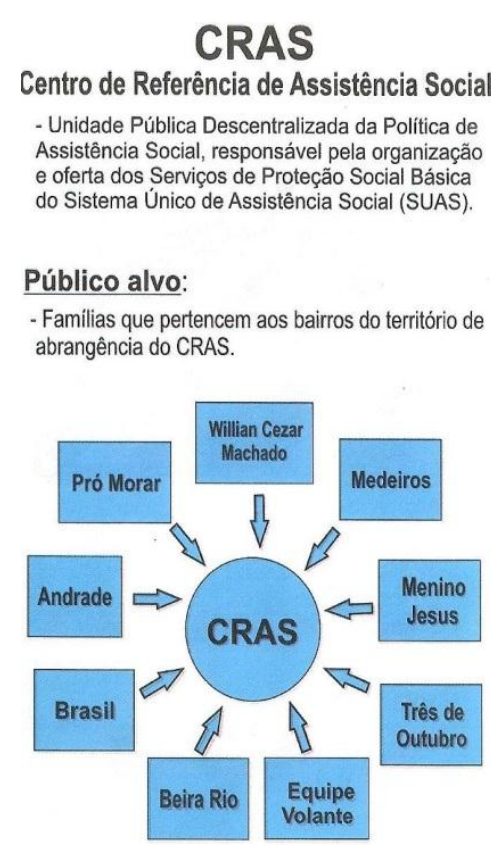

Objetivo: Prevenir a ocorrência de situações de vulnerabilidades e riscos sociais através do Desenvolvimento de potencialidades, fortalecimento de vinculos familiares e comunitários e ampliação do acesso aos Direitos de Cidadania.

\section{Serviços Ofertados no CRAS:}

- Recepção e acolhida;

- Serviço de Proteção e Atenção Integral à Família;

- Atendimento psicossocial com procedimentos profissionais em defesa dos Direitos Humanos e Sociais da Proteção Básica;

- Acompanhamento das familias;

- Proteção proativa através de visitas às famílias;

- Encaminhamento á rede socioassistencial;

- Divulgação de informações sobre programas, projetos e serviços;

- Acompanhamento às familias inseridas no Programa Bolsa Família;

- Apoio nas avaliações de revisão e de encaminhamento para aquisição de Benefício de Prestação Continuada (BPC) para idosos e pessoas com deficiência do território;

- Grupos de convivência para famílias, idosos, adolescentes e crianças (6 anos).

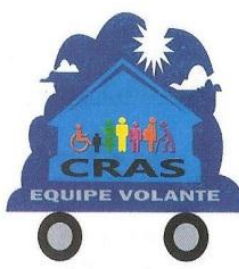

A Equipe Volante consiste em uma equipe em uma equipe adicional que integra um Centro de Referência de Assistência Social (CRAS) em funcionamento, com o objetivo de prestar serviços no território de abrangência do referido SRAşos no território de abrangência do referido

Essas familias vivem em locais de dificil acesso distantes desta unidade física, ou estão dispersas no território. A Equipe Volante é responsável por realizar a busca ativa destas famílias, desenvolve - Serviço de Proteção e Atenção Integral à Familia (PAIF) e demais serviços de Proteção Básica que poderão ser adaptados às condições locais especificas, desde que respeitem seus objetivos.

A Equipe Volante também é responsável por incluir as familias no Cadastro Único, realizar os encaminhamentos necessários para acesso à renda, para Serviços de Proteção Especial e pare serviços de outros setores, sempre que couber.

PÚBLICO ALVO: Famílias que residem em territórios com baixa densidade demográfica com espalhamento ou dispersão populacional (áreas rurais, comunidades indigenas, calhas de rios, quilombolas, assentamentos, dentre outros).

Folder, com duas dobras. $2^{\mathrm{a}}, 3^{\mathrm{a}}$ e $4^{\mathrm{a}}$ página. Cras Menino Jesus. São Gabriel/RS. 
Figura 10

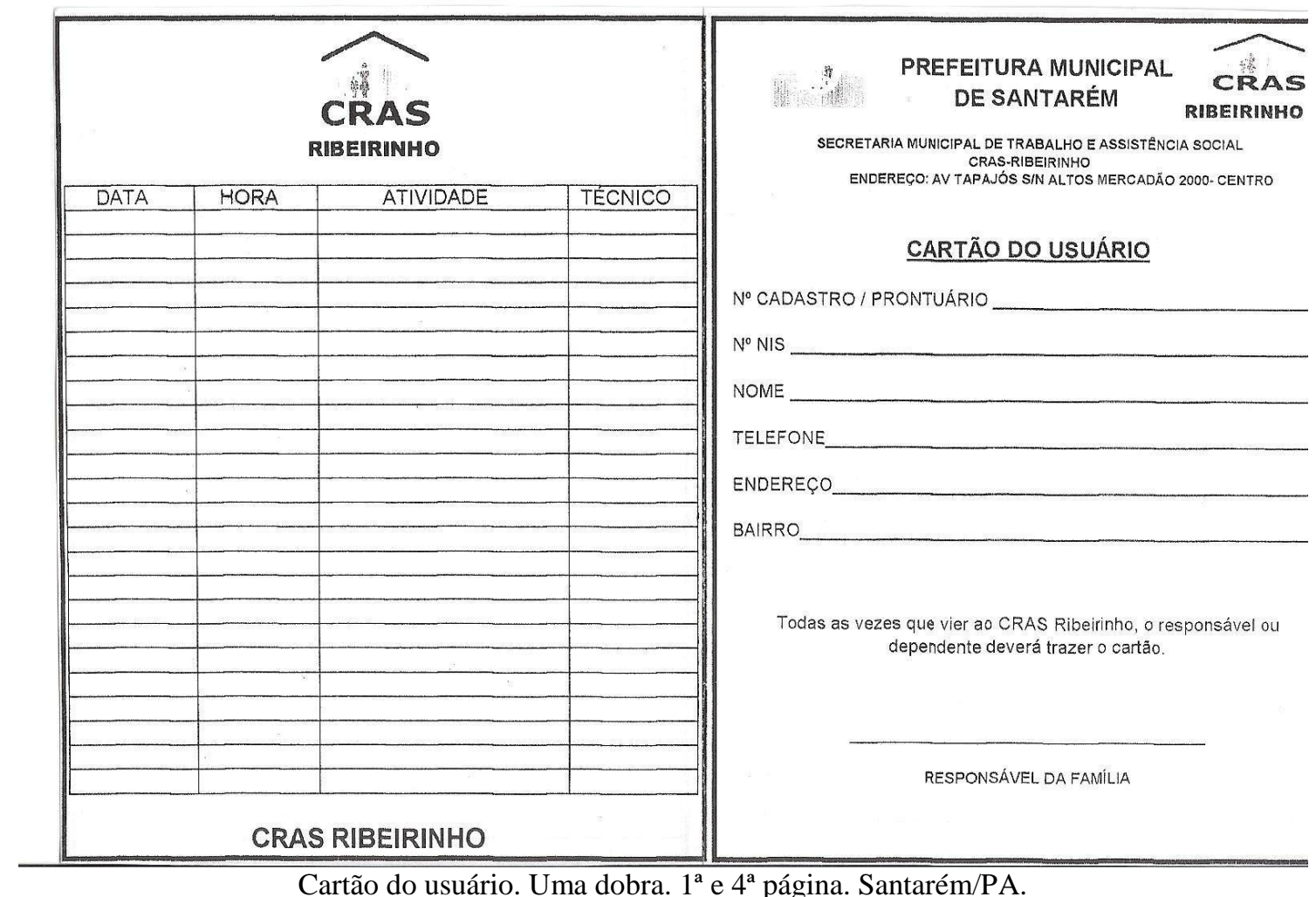

Cartão do usuário. Uma dobra. $1^{\mathrm{a}}$ e $4^{\mathrm{a}}$ página. Santarém/PA.

Outra atividade cotidiana dos Cras está articulada à oferta de cursos e de oficinas que, de acordo com alguns usuários, significa a oportunidade de melhorar o futuro por possibilitar alterações no mundo do trabalho, mais valorização e remuneração, bem como uma elevação da autoestima e a promoção da sociabilidade. Sentem-se gratificados, prestigiados e otimistas por isso, como podemos ver nas falas de dois usuários:

Estou feliz de estar aqui com as colegas que são maravilhosas e as professoras também. Tem ginástica, a costura. (Usuária 2, São Gabriel/RS).

Eu já fiz bonequinho aqui, já fiz muitas oficinas. Eu gostei demais e tem um lanche muito gostoso. (Usuária 5, de Belo Horizonte)

À exceção do Cras Ribeirinho, em Santarém/PA, por estar, na época de nossa visita, recém-inaugurado, todos os Cras visitados oferecem oficinas e cursos. Assim, as observações de campo permitiram um contato com os profissionais que são contratados para ministrar cursos e oficinas. Trata-se de profissionais que detêm conhecimentos técnicos, tais como: corte e costura; artesanatos em geral; musica; danças; capoeira; bordados, corte de cabelo; aplicação de químicas no cabelo, operador de máquinas pesadas, de motor de álcool e de diesel, eletricista industrial, encanador, panificação e 
outros. Além disso, muitos dos materiais produzidos por eles são colocados à venda, o que possibilita um retorno financeiro para os/as matriculados/as. São profissionais dotados de habilidades, muitos inclusive reconhecidos no município, mas poucos deles estão formados sobre as especificidades da Assistência Social e das especificidades do perfil desse aluno(a). Abaixo, pode-se verificar o curso de música oferecido em São Gabriel/RS por meio do ensaio da banda (Foto 9) e o espaço para a oficina de costura industrial em Rubiataba/GO (Foto 10). 


\section{Foto 9}

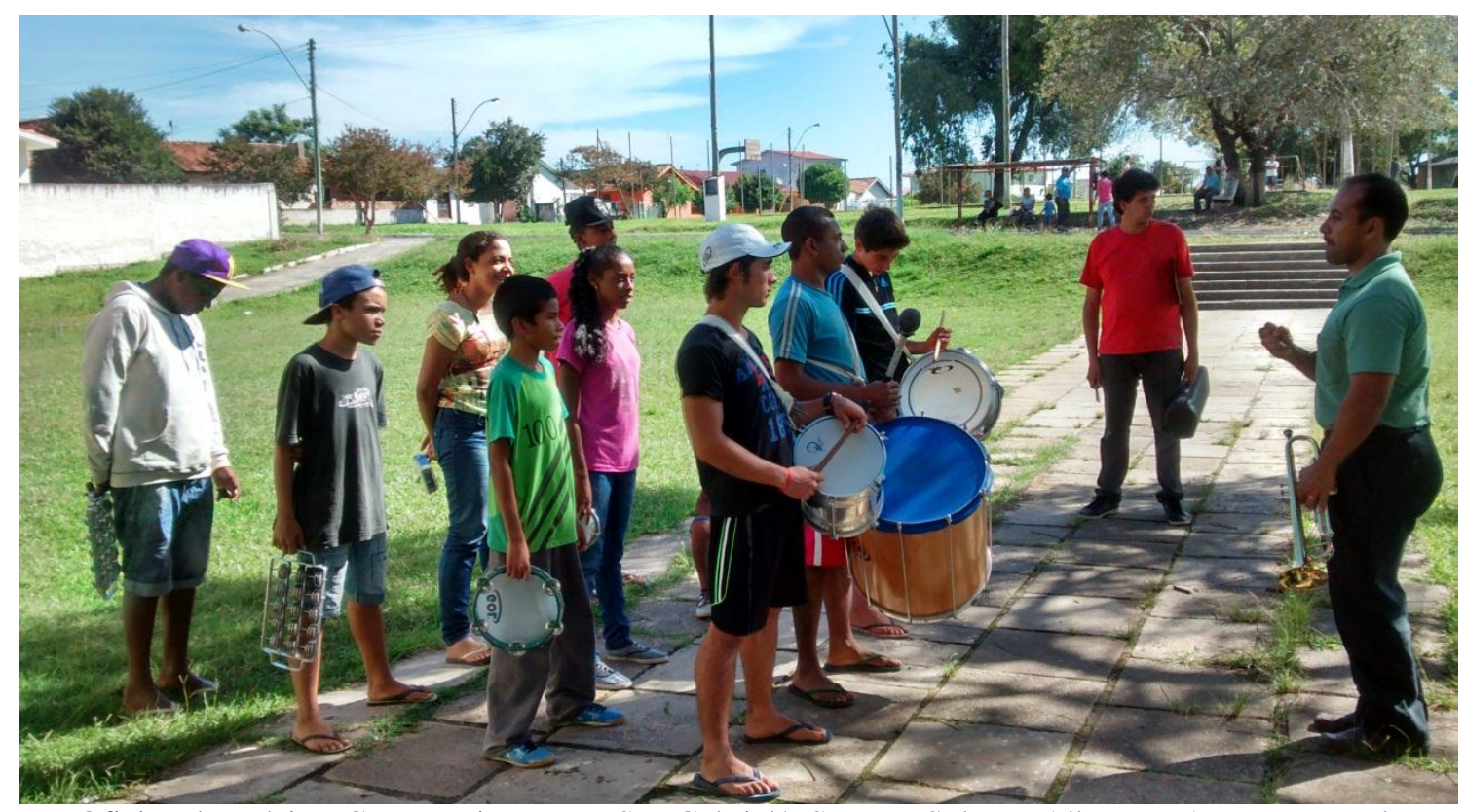

Oficina de Música. Cras Menino Jesus. São Gabriel/RS. Foto: Solange Albernaz. Acervo pessoal.

\section{Foto 10}

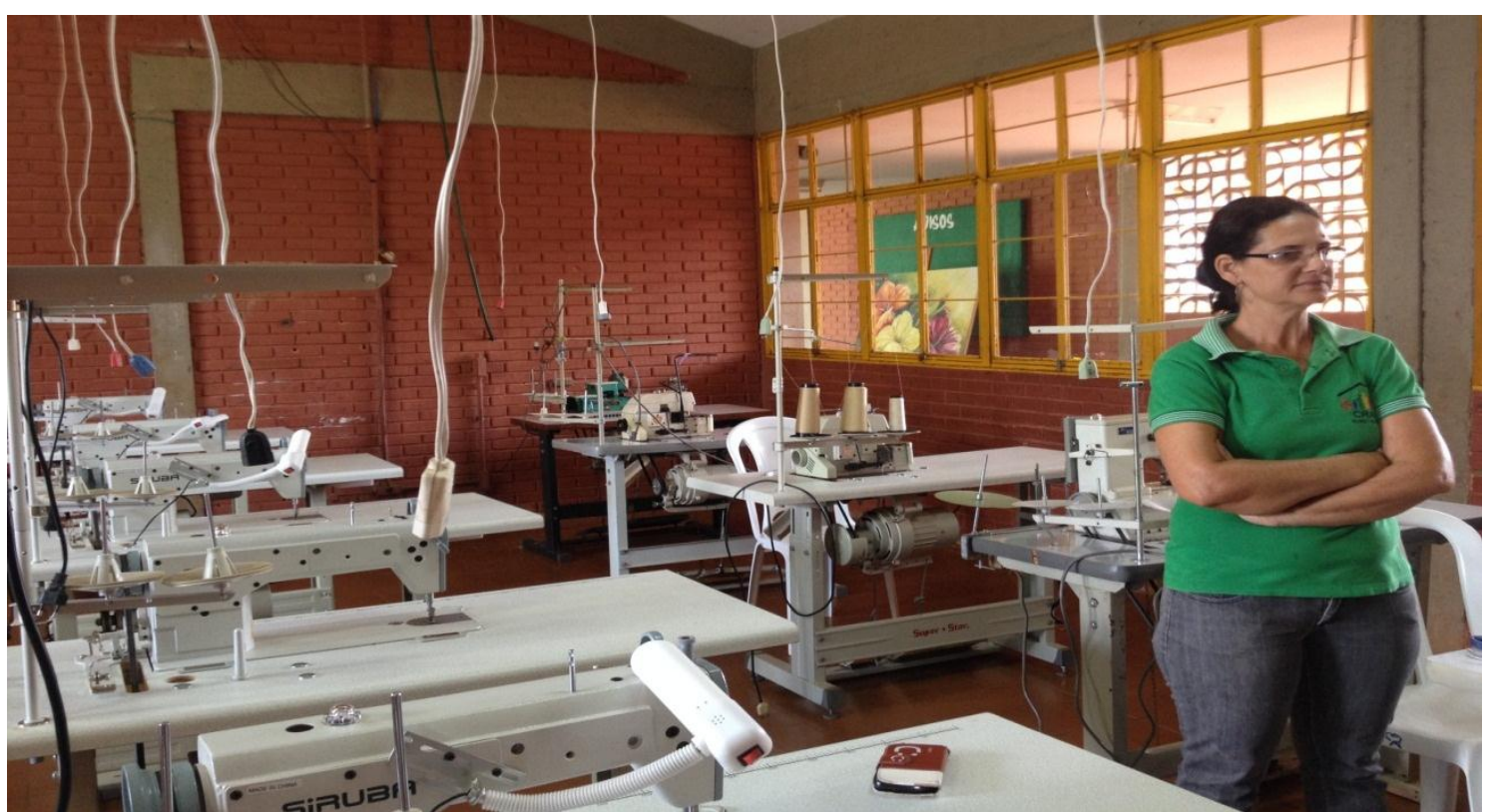

Oficina de costura industrial. Rubiataba/GO. Foto: Solange Albernaz. Acervo pessoal.

Foi possível identificar, na maioria dos Cras, a ausência da formação cidadã nessa modalidade de serviços, perdendo-se a oportunidade da comunicação direta (Duarte, 2009), que, por sua vez, permite um contato personalizado, geralmente do tipo face a face e que pode ser ajustado imediatamente às características dos interlocutores. A oficina fica, portanto, limitada ao conhecimento técnico operativo. 
Outro serviço ofertado pelos Cras são as reuniões mensais do Paif, cujos temas são extraídos geralmente nos próprios encontros coletivos. Muitos dos temas são ministrados por agentes externos, como, por exemplo, profissionais da Caixa Econômica Federal, para abordar sobre habitação e o Programa Bolsa Família, bem como profissionais do Sistema $S^{85}$ convidados para comentar sobre a questão da qualificação profissional e da inserção no mundo do trabalho. Trata-se, portanto, de um momento em que a comunicação é um processo maior do que informar, deflagrando um processo que requer um tempo maior para se consolidar, como apontou Monteiro (2009), dado que seu objetivo é qualificar o cidadão para exercer sua autonomia pessoal e política.

$\mathrm{Na}$ oportunidade da pesquisa foi verificado que temas como sexualidade, saúde da mulher e outros temas afins interessam aos usuários e aos técnicos de um modo geral, sendo que quando articuladas às palestras e às oficinas nem sempre o tema é tratado na ótica da saúde pública, e sim por religiosos, como foi verificado em Santarém, podendo-se averiguar por meio da fala de umas das técnicas abaixo.

\begin{abstract}
A gente faz as reuniões e pergunta as dificuldades que tem e elas próprias nos colocaram os temas que elas querem que seja tratado. Vários temas, gerenciamento, conselho tutelar e as interfases já esteve em nossas reuniões. Elas gostam de vir. Já virou a reunião do Bolsa. A gente incentiva pra vir as reuniões, traz temas e pegou. Não é só o acompanhamento de tu ir fazer visita. Elas gostam de vir e participar. (Técnica do Cras Menino Jesus. São Gabriel/RS)

A gente tem parceria com as igrejas, elas sempre dão palestras principalmente no projeto de meninas grávidas de 12 a 15 anos e senhoras de 40 a 50 anos grávidas. (Técnica do Cras Urumari. Santarém/PA)
\end{abstract}

Os dados do Censo Suas/Cras 2014 informam sobre os vários temas desenvolvidos pelos Cras. O direito social, com suas especificidades, é a base de todos os temas. De um modo geral, trata-se de uma ressignificação da inserção e do papel social do sujeito, como se pode verificar na tabela abaixo.

\footnotetext{
${ }^{85}$ Sistema S - Sesc, Sesi e Senai.
} 
Tabela 4 - Principais temáticas abordadas nos grupos do Paif

\begin{tabular}{|l|c|c|}
\hline \multicolumn{2}{|c|}{ Principais temáticas abordadas nos grupos do Paif } \\
\hline \multicolumn{1}{|c|}{ Quantidade de Cras } & $\%$ \\
\hline $\begin{array}{l}\text { Direito à transferência de } \\
\text { renda e benefícios } \\
\text { assistenciais }\end{array}$ & 5.651 & $82,0 \%$ \\
\hline $\begin{array}{l}\text { Direito a Documentação Civil } \\
\text { Básica (certidão de } \\
\text { nascimento, CPF, RG, título } \\
\text { eleitoral) }\end{array}$ & 4.373 & $63,5 \%$ \\
\hline Direito a cultura e lazer & 3.949 & $57,3 \%$ \\
\hline Direito das Mulheres & 5.480 & $79,5 \%$ \\
\hline $\begin{array}{l}\text { Direitos das pessoas com } \\
\text { deficiência }\end{array}$ & 3.952 & $57,4 \%$ \\
\hline Direito à Alimentação & 3.747 & $54,4 \%$ \\
\hline Os direitos das famílias & 5.533 & $80,3 \%$ \\
\hline $\begin{array}{l}\text { As especificidades do ciclo } \\
\text { vital dos membros das } \\
\text { famílias }\end{array}$ & 3.235 & $47,0 \%$ \\
\hline Cuidar de quem cuida & & $50,7 \%$ \\
\hline $\begin{array}{l}\text { O uso de álcool e/ou outras } \\
\text { drogas na família }\end{array}$ & 3.490 & $68,5 \%$ \\
\hline $\begin{array}{l}\text { Problemas e soluções do } \\
\text { território }\end{array}$ & 4.719 & $38,6 \%$ \\
\hline $\begin{array}{l}\text { Diversidade cultural, étnica e } \\
\text { social }\end{array}$ & 2.658 & $51,5 \%$ \\
\hline Quantidade de Cras que responderam essa pergunta & 6.889 \\
\hline
\end{tabular}

Fonte: SNAS/DGSUAS/CGSVIS - CENSO SUAS 2014, p. 13.

Outra atividade desenvolvida nos Cras, que tem sua base na informação de utilidade pública, é denominada de Busca Ativa, que é uma atividade do Paif prevista nas normativas cujos objetivos são: buscar novos sujeitos que tenham direito aos serviços da Política de Assistência Social, mas desconhecem, e mobilizar a comunidade em torno de assuntos de interesse geral, percebidos, a princípio, por meio de diagnósticos sociais. Sobre o Busca Ativa, os técnicos informam regularmente vão nas comunidades usando um uniforme para se identificar. Em algumas ações, principalmente quando envolve outras secretarias, conseguem melhor infraestrutura, como, por exemplo, um carro de som, entre outros instrumentos de comunicação.

Com base no que foi elencado, há muitas contradições entre o que é proposto pelas normativas a respeito da estrutura e do padrão de qualidade e o implantado. Como a própria norma afirma: a estrutura do espaço físico do Cras é reflexo de uma 
concepção. Portanto, há uma concepção e uma prática diferentes das deliberações do CNAS e das Conferências de Assistência Social e dos pactos estabelecidos entre as CIB's e CIT.

Ao analisar as particularidades do fenômeno na totalidade, percebe-se que a travessia no deserto que elevou a Assistência Social à condição de política pública social não significou a ruptura com a lógica de liberal que não a considera como um componente das políticas de desenvolvimento econômico e social, deixando-a refém das velhas práticas fundadas no improviso, no voluntarismo e no messianismo. A estrutura física deficitária termina por colaborar para a perpetuação de práticas não condizentes com a vida democrática. Permanece a correlação de forças entre a efetivação da lógica da proteção social e a reedição do mito fundador, representados por aqueles que se inserem no novo formato da Assistência Social, mas repetem as velhas práticas. Como afirmou Silva (2014, p. 162), “a política de Assistência Social move-se em um espaço contraditório e, muitas vezes, assume a lógica instituída de clientelismo e de favores, reiterando essa realidade imposta".

Essa correlação de forças se exprime por meio de muitas práticas conservadoras. Um exemplo é o estado de Goiás que, em pleno reordenamento da política de Assistência Social, usa os recursos da Assistência Social como moeda de troca, reatualizando o patrimonialismo/clientelismo, como se pode verificar no depoimento em entrevista de uma técnica do Cras de Rubiataba/GO, onde o governo do estado limita o repasse de recursos materiais e financeiros apenas para os municípios e entidades de seu interesse político.

\footnotetext{
O nosso prefeito aqui é oposição ao governo e o mecanismo que nós temos na área de assistência nós não temos respaldo. Nem para o estado de Goiás ele não manda recurso para a assistência social. É uma briga nossa contra o estado e estamos brigando aí nas conferências, as verbas estaduais que o governo repassa nos recursos para a área de assistência. Só fica na ONG o recurso, caso contrário a gente não consegue o mínimo como cadeira de rodas, fraudas... nunca tem pra nós. Se tiver outro município lá entregam um caminhão. Então não temos essa comunicação em relação ao recurso do estado. (Técnica do Cras. Rubiataba/GO)
}

Outra manifestação do conservadorismo é a presença do primeiro-damismo na gestão da Assistência Social, verificado pela pesquisa de campo nos municípios de Santarém/PA e Rubiataba/GO, sendo que no município de Goiás o lema da política é “Assistência Social, um projeto de amor”. Além disso, por ocasião da visita, foi solicitado que a pesquisadora proferisse uma oração junto a toda equipe técnica do Cras 
para o inicio dos trabalhos do dia, sendo essa uma prática diária. Revela-se nessa experiência no campo de pesquisa uma concepção de Estado como uma extensão do âmbito privado e a assistência social como um "projeto de amor". Ainda que muito engajados, extremamente dedicados e comprometidos com o trabalho, o que se percebe é que a Assistência Social não se efetiva como direito à medida que no Estado ainda transita o estímulo dado pela própria gestão à contribuição do trabalhador como uma doação, como falaram alguns técnicos se referindo aos baixos salários, aos empréstimos de carros para atividades profissionais, selado pelo apelo ao espirito religioso, colocando por terra a concepção de que o Estado é laico. Ainda, nesse município, na visita à Aldeia Indígena dos Tapuias com membros da equipe de referência volante, estes foram informados por uma professora da escola da Aldeia que uma mãe indígena precisava recadastrar os filhos no Programa Bolsa Família, mas não estava conseguindo falar no Cras. Com cordialidade, a resposta da agente pública foi que o Cras tinha mudado de endereço, estando todos os equipamentos desconectados, inclusive o telefone. Por meio dessa resposta, observa-se que a mudança física do Cras não foi divulgada para os usuários, sob o argumento de que eles são acompanhados por uma equipe volante do Cras e não precisariam, a princípio, realizar o deslocamento. No entanto, se o argumento é pela ausência da necessidade do deslocamento, por que o recadastramento de quase todas as crianças da aldeia não é realizado no próprio local? Acredita-se que a base dessa resposta está no comentário corrente entre alguns técnicos, de que "os índios Tapuias tem uma vida boa, pois a Funai dá tudo, inclusive eles têm uma caminhonete para ir pra tudo quanto é lugar que quiserem".

Outro momento da pesquisa de campo demonstra que o direito à proteção social não está claro para os operadores à medida que estes não compreendem aspectos das estratégias de sobrevivência dos subalternos e nem a cultura local, quando uma técnica do Cras Urumari em Santarém aponta que o problema está na população, e não na forma como historicamente as necessidades sociais da classe trabalhadora foram tratadas no Brasil. Seja:

Mas em termos de crescimento hoje eu vejo essa parte do social dos
programas do governo ele tenta ajudar, mas o povo tem um pensamento
muito errado de dizer: enquanto eu estiver me beneficiando eu não vou
procurar melhorar / Aqui existe um problema muito grande que é a questão
de que falam muito do "gato" com esse aumento de energia em Santarém de
$35 \%$. É uma realidade aqui nessa população, é carência mesmo, falta de
trabalho / É uma Busca Ativa ainda devagar porque a divulgação, mas elas
(comunidade) aqui na parte da manhã têm o costume de dormir muito. Você
só pode ir na casa de alguém aqui depois das dez ou onze horas porque não 
tem a perspectiva de ir para o trabalho e fazer alguma coisa e então a questão é dormir. Dorme tarde. Acorda tarde. (Técnica do Cras Urumari. Santarém/PA)

Essa correlação de forças hegemonizada ainda pelo pensamento conservador reforça a condição subalterna da própria política, dos gestores e dos trabalhadores, como corroborou Silva (2014), revelado, inclusive, no baixo investimento financeiro destinado aos serviços socioassistenciais. ${ }^{86}$ É certo, como apontou Simone Albuquerque, diretora à época do Departamento de Gestão do Sistema Único de Assistência Social/MDS, em entrevista, na ocasião da pesquisa exploratória, que os municípios e os estados gozam de autonomia administrativa na aplicação dos recursos financeiros proposto pelo governo federal, estando, portanto, a aplicação desses recursos sujeitas à concepção política ideológica dos governantes e dos gestores, que se manifesta em escolhas que incidem desde a infraestrutura até no perfil, na forma de seleção, de contratação e nos salários dos trabalhadores sociais.

Essa força politica conservadora em presença reedita a síndrome do Bom Samaritano, ${ }^{87}$ que motiva a todos a doarem camuflando as condições de trabalho, a realidade dos salários, a ausência de profissionais de outras áreas importantes ao trabalho social, as condições reais dos equipamentos, a precariedade da formação profissional dos agentes públicos e transforma tudo em queixa. Queixam-se dos componentes da gestão, dos técnicos, dos usuários, como apontou o secretário de Belo Horizonte, por ocasião da pesquisa exploratória, sem que com isso movimentem e alterem efetivamente a realidade.

\footnotetext{
${ }^{86}$ Há um movimento promovido por entidades que atuam na área da Assistência Social que reivindica que seja assegurado $10 \%$ do Orçamento da Seguridade Social para os serviços continuados da Assistência Social, uma vez que a maior parte dos recursos é destinada aos programas de transferência de renda. De acordo com o IPEA em 2009, 93\% do orçamento do Ministério de Desenvolvimento Social e Combate à Fome foram destinados ao pagamento de benefícios monetários. Em 2013, o Conselho Federal de Serviço Social/CFESS, apontou que o governo gastou $74 \%$ do orçamento da Seguridade Social com a Previdência Social, $15 \%$ com a Saúde e $11 \%$ com a Assistência Social, sendo, no caso da Previdência, recursos oriundos dos contribuintes. No entanto, apenas 1,05\% do orçamento da Assistência Social foi para o cofinanciamento dos serviços, programas, projetos, política de educação permanente e os planos do governo federal (Brasil Sem Miséria, Enfrentamento ao Crack e outras drogas, Viver Sem Limites). Nas regulamentações do SUAS, a manutenção dos serviços socioassistenciais são compartilhadas pelas três esferas de governo. Silva (2012) aponta que, em setembro de 2009, foi firmado um pacto denominado de Protocolo de Gestão Integrada de Serviços, Benefícios e Transferências de Renda no âmbito do Sistema Único de Assistência Social, estabelecendo que o público beneficiário de programas de transferência de renda seja atendido prioritariamente nos serviços socioassistenciais. Para a autora, embora se reconheçam os avanços apontados no Protocolo, há um risco de se criar uma seletividade no acesso aos serviços ofertados, visto que nem sempre as pessoas e famílias cadastradas no CadÚnico são inseridas nos programas de transferência de renda como o Bolsa Família.

${ }^{87}$ A Síndrome do Bom Samaritano é uma parábola contida na Bíblia, no Novo Testamento, Lucas 10:3037. Trata-se da compaixão que se deve ter com o próximo, de forma a assistir os desassistidos e compartilhar o que se possui.
} 
Ao conservadorismo liberal, que se expressa historicamente em vários níveis de governos e também por meio de organismos de representação da sociedade civil, interessa essa condição que não possibilita aos usuários perceberem a diferença entre o novo que se lança e o instituído, com o intuito de que estes não se coloquem como sujeitos da política, fortalecendo os processos democráticos e a cidadania, dado sua articulação simbiótica. Como afirmou Coutinho (2000, p. 129), "a democracia é soberania popular, é construção de uma comunidade participativa, é igualdade", portanto, um valor universal por ser um processo.

Embora a Assistência Social enquanto política pública seja nova no país, ela se ressente da terceira etapa, denominada pela diretora de Gestão do Sistema Único de Assistência Social/MDS à época como a fase de qualificar o sistema, ressaltando que a comunicação sequer entrou em pauta. Contudo, ao considerar a Comunicação Pública como um todo, importa qualificar os espaços físicos, dotando-os de um padrão visual que rompa com a impessoalidade, com a austeridade do passado e com o improviso, tão típicos de nossa formação histórica, marcada pelo paternalismo, pelo patrimonialismo e pelo populismo; investir na locomoção dos funcionários para as atividades precípuas do equipamento com linhas telefônicas disponíveis para celular e materiais de comunicação produzidos na justa medida para serem reproduzidos nas recepções e em outros espaços de intervenção da política; e investir na capacitação dos trabalhadores para além das normativas e da estrutura do Suas, entre outros.

Vistas e analisadas as condições estruturais dos Cras, a prestação e a dinâmica dos serviços ofertados e as questões mais gerais da política de Assistência Social, percebendo as contradições em decorrência das disputas de concepções e das forças políticas em presença, importa verificar como a comunicação se organiza e flui nessa estrutura com suas correlações de forças.

\subsection{A Comunicação Pública nos Cras}

Este subcapítulo tem como proposta evidenciar a essência sobre a comunicação nos Cras, o que requer a compreensão de que a realidade é em si mesma uma totalidade constituída de totalidades de maior ou menor complexidade, sendo que "toda formação social é suficientemente contraditória, para ser historicamente superável" (Demo, 1995, p. 89). Para tal, subdividiu-se em três blocos, na expectativa de dar transparência ao processo de abstração no qual são estabelecidas as diferenças, as semelhanças e as 
articulações que ocorrem no interior do objeto de estudo, mas sempre articulando a universalidade, a particularidade e a singularidade. Por isso, no primeiro bloco buscou-se compreender a comunicação numa totalidade interna e externa à Assistência Social, sob o olhar dos técnicos dos Cras, das gerências correlatas e dos representantes dos usuários no CMAS, uma vez que os últimos debatem e deliberaram sobre a política.

O segundo bloco traz uma análise sobre as considerações e as ações dos técnicos envolvidos com a proteção social básica em relação à comunicação com os usuários, evidenciando as condições objetivas e subjetivas, bem como as contradições e mediações presentes nos processos comunicativos junto aos usuários.

O terceiro bloco apresenta a compreensão dos usuários sobre as questões que circundam a Assistência Social e analisa, tendo como referência os princípios da Comunicação Pública estatal, entre outras especificidades.

\subsubsection{Comunicação na Assistência Social: totalidades que desafiam um todo}

Na perspectiva da dialética, a Comunicação Pública no Cras tem relação com a totalidade da política de governo e com o sistema de gestão descentralizado e participativo da Assistência Social, que estão inseridos, por sua vez, no contexto do capitalismo monopolista, cuja dinâmica no Brasil contém particularidades, considerandose o processo histórico de formação social e política desse país. A compreensão dos técnicos sobre a dinâmica da comunicação na Assistência Social a partir do cotidiano do trabalho apontou para algumas contradições existentes mesmo em se tratando de uma estrutura de gestão que assegura internamente espaços de debates, deliberações e pactos.

Entre 2012 a meados de 2015, observou-se que as informações postadas sobre a política de Assistência Social, no site do MDS, eram direcionadas explicitamente para gestores e para conselheiros. À época da pesquisa exploratória, a assessora de comunicação do MDS, Adriana Moraes, informou que o site tinha muitos problemas técnicos, dificultando a postagem das informações. Mesmo assim, na análise dos técnicos, a comunicação interna sobre a política, a partir do Suas (2004), melhorou significativamente em função da utilização dos recursos tecnológicos e da produção e distribuição de materiais impressos e capacitações, possibilitando a circulação das deliberações dos fóruns de discussões, bem como a compreensão das normativas, entre outros, como pode-se verificar pelo depoimento abaixo: 
Na comunicação a nível nacional, estadual e municipal eu vejo que melhorou bastante. A gente tem acesso a todas as movimentações, a documentação, até mesmo porque a gente precisa porque a política de Assistência Social vem nas conferências com as deliberações. A gente tem que estar sempre atualizada e tentando colocar em prática [...] a gente tem o costume de entrar todo dia no site pra ver essa documentação, e-mails também do governo federal, do estadual em qualquer situação que ocorra. Reuniões da CIT, do Conselho Nacional. A gente está sempre informada dessas situações que acontecem. (Técnica do Cras Menino Jesus. São Gabriel/RS)

De 2005 pra cá muita coisa melhorou aqui porque hoje a descentralização de alguns programas e a questão do Cras. Nós podemos trabalhar de uma forma muito mais independente, mas também em conjunto, né? [...] Essa é a comunicação do MDS com a gente. Eles mandam o material impresso que ajuda muito. Tivemos o Capacita-Suas do dia $1^{\circ}$ ao dia 4 de julho deste ano e todos os assistentes sociais que participaram receberam uma bolsa com bastante material. Tudo atualizado. NobRH 2012, esses prontuários Suas e alguns livros explicando a história do Suas, o estatuto da pessoa idosa, recebemos um bom material para estarmos trabalhando. (Técnica do Cras Ribeirinho. Santarém/PA)

Embora na atualidade o site esteja totalmente revisado, estando mais didático e acessível, inclusive com um acesso direto para a imprensa, é pouco provável que ele contribua sem haver um direcionamento para a superação de uma questão destacada pelos técnicos e que diz respeito à comunicação com outras áreas das políticas sociais, como Saúde e Educação. Os técnicos afirmam que os trabalhadores especializados de outras áreas não apreendem um entendimento acerca das especificidades da Assistência Social. Acreditam que por algum motivo que atribuem à gestão, mesmo aparecendo como deliberação nas conferências, a exemplo de Belo Horizonte, a comunicação não entra na agenda, dificultando o cotidiano dos serviços intersetoriais, como afirma uma técnica no depoimento abaixo.

Acho que a comunicação não entrou ainda nem na pauta. Por mais que eu veja nas conferências os usuários clamando e as deliberações, de dois em dois anos, mas, eu nunca vi ela se materializar como uma agenda da secretaria. [...] Acho que é uma questão que tem sido deixada pra segundo plano. Nós comunicamos muito mais pra dentro, para os trabalhadores, para os gestores e pouco pra fora. Aí falo da comunicação institucional. Nós não temos uma comunicação institucional nos serviços. não tem uma diretriz da comunicação com o usuário. A comunicação da política de Assistência Social ela ainda é endógena, ela é pra dentro. O tanto que eu ouço da Educação e Saúde o que é acompanhamento familiar mesmo? Anos participando de GT's e reunião e desenhando e eles continuam perguntando o que é esse acompanhamento familiar? [...] A política de Assistência Social sempre aparece repetitiva, né? Ou é pra resolver um problema da população de rua ou BH Cidadania. Ela está sempre com uma máscara, mas não é a política de assistência social a oferta de um direito a esse usuário. Acho que isso fragiliza também esse recorte dessa política, hoje em dia é difícil falar de Suas. A gente tem tido essa dificuldade. (Técnica da Gerência de Coordenação da Proteção Social Básica de Belo Horizonte/MG) 
Essa falta de compreensão da Assistência Social por técnicos de outras áreas e da sociedade de um modo em geral se justifica, para alguns técnicos, em função da inexistência de uma política de comunicação que dê à política uma visibilidade maior. Acreditam que um dos motivos decorre da dimensão do Programa Bolsa Família, em que pese a absorção de muitos Cras na atividade do cadastramento e da adesão total ao acompanhamento dos beneficiários. Ou seja, em virtude da visibilidade desse programa, não se investe na publicidade da Assistência Social enquanto uma política de governo, como afirmaram vários técnicos em entrevistas, podendo ser verificado no depoimento abaixo de uma técnica em Tobias Barreto/SE.

A gente ficou meio que refém na política de assistência do Bolsa Família. Mesmo nessa função que a gente tenta fazer de trazer o cadastro pra dentro do Cras para que o serviço seja valorizado com um todo. A gente ainda não conseguiu passar este programa como um programa que está inserido dentro de uma politica. A gente ficou meio do Bolsa Família porque é um programa de expressão enorme. Mundial, porque quantas pessoas o Bolsa Família não atinge? Então eu acho que a política tem que encontrar um meio termo de não desvalorizar o programa que é extremamente importante. (Técnica do Cras 2. Tobias Barreto/SE)

Outra questão que os técnicos destacaram foi a relação que os meios de comunicação comercial têm com a Assistência Social. Na opinião deles, a mídia compreende a pobreza com base na meritocracia e no clientelismo, não havendo um contraponto à altura que enfrente essa concepção. Alguns acreditam que a relação com a mídia se dá por questões de afinidade política entre o meio e a gestão. Outros consideram que as informações de utilidade pública, como inaugurações, horários de funcionamento e etc., é o que recebe adesão da mídia, como pode-se verificar abaixo.

Sobre a mídia, não existe o entendimento do nosso serviço. Acho que isso é pra todo lado. E aqui em Tobias Barreto tem o quarto poder que é violento. Um vereador aqui que é radialista que só Jesus na vida dele. Tudo é contra o prefeito e fora as opiniões. Os poucos que eu conheço eles têm a mesma visão. Porque nós estamos ali para dar cesta básica, pra fazer caridade. O que a gente fez foi uns foros que a gente faz de mesa redonda. A gente fala, solicita deles a presença, que eles estejam também para ouvir um pouco sobre o que é o nosso trabalho. Aqui a gente até tem uma relação legal. A gente tem que começar sempre porque eles mudam muito, mas a gente tem esse trabalho de ir lá, dizer, conversar. (Técnica do Cras 2. Tobias Barreto/SE).

Numa sociedade de consumo a mídia reforça muito mais o campo das necessidades imediatas e a mídia não tem um entendimento claro sobre o que vem a ser a política de assistência social, então todas as vezes que a mídia trata a assistência social na maior parte das vezes não a trata como politica. Ela trata como ação. Tanto é que os aspectos que mais vemos são os aspectos do voluntariado, das benfeitorias do lado humano do que o direito humano de ter acesso a uma das politicas de seguridade social. [...] Nossa! Mídia e 
assistência social balança. Constantemente estamos aqui no Balança ${ }^{88}$. População de rua então. A mídia não consegue entender dessa política. É uma mídia que está preparada para levantar os erros. Uma posição equivocada ainda da assistência não como direito, mas uma política assistencialista que protege, passa a mão na cabeça do pessoal. Recentemente fomos dar uma entrevista sobre o migrante e quando pegou o corte da reportagem só saiu um trechinho. Acho que ainda não conseguimos construir uma pauta geral na imprensa. A própria imprensa da prefeitura de assessoria de comunicação para divulgar a implantação eles não têm conteúdo. E isso dificulta o próprio usuário entender que ele está fazendo parte de uma política. (Técnicas da Gerência de Coordenação da Proteção Social Básica de Belo Horizonte/MG).

No geral acho que somos privilegiados aqui em São Gabriel. Não vejo a assistência social aqui colocada em desprestigio não. Acho que aqui a gente é privilegiado nos meios de comunicação. O secretário participou hoje das entrevistas e coisas assim. Os meios de comunicação não tem esse meio de conhecimento suficiente ainda para tirar esse mito (do assistencialismo). (Técnica do Cras Menino Jesus. São Gabriel/RS)

Nesse tempo que estivemos aqui sempre veio pessoas da mídia e pediram que falássemos sobre serviços para eles fazerem divulgação. Para trazerem mais famílias para os Cras e para saber para que público estamos voltados. Depois da inauguração do Cras aqui aumentou bastante o número de cadastros de pessoas procurando o Cras aqui. (Técnica do Cras Ribeirinho. Santarém/PA)

O representante dos usuários no CMAS de Belo Horizonte aponta a necessidade de se investir na comunicação de massa, para divulgar a política de Assistência Social, por ser a melhor forma de falar com o usuário.

a divulgação deveria ser mais no nível de jornal, rádio, televisão que atinge mais a massa. O governo deveria divulgar mais o que é o Cras. Muitas vezes o Cras é instalado em uma região e os moradores em si não conhecem o Cras. Sempre levo folhetos informativos. Fica difícil divulgar uma coisa que as pessoas não sabem o que é [...] a comunicação tem que ser constante. A distribuição impressa é muito importante, mas o mais é o boca a boca. É isso que divulga mais. Você levar a pessoa lá, ele vai ver o que é e transmitir ao outro. Apesar de que o rádio e a televisão falando já vão associar e quando você fala com a pessoa ela diz: já ouvi isso na rádio. No caso do rádio seria essa comunicação do boca a boca e aí entra o conselheiro, o Cras, as comissões locais divulgarem os equipamentos, o que é a assistente social que na verdade nós ainda pensamos que assistente social é para dar cesta básica, vale transporte. (Representante dos usuários no CMAS. Belo Horizonte/MG)

O usuário compreende que "o Suas veio para dar uma nova visão para a população. A população ainda não está entendendo e misturam o Sus com o Suas”. Na opinião dele, um dos motivos que geram essa confusão é que as siglas são quase idênticas e confundem o usuário. Acredita ainda que o trabalho do Cras altera as relações políticas porque discute a respeito dos direitos, e isso não agrada aos políticos.

O Cras tira muito isso do político. O político não gosta muito quando você começa a aprender e vai num equipamento desse aí e começa a aprender seus direitos. Então um lado é Cras, é vamos discutir, vamos conversar e fazer

\footnotetext{
${ }^{88}$ Referência ao programa Balanço Geral, da Record Minas.
} 
reuniões. Daí você começa a reconhecer que você é um cidadão e como cidadão tem alguns deveres, mas também têm direitos. Isso cria na pessoa a cidadania e a pessoa começa a participar mais da sociedade. Onde é implantado o Cras as pessoas participam mais. (Representante dos usuários no CMAS. Belo Horizonte/MG)

De acordo com as análises dos entrevistados, observa-se que a Comunicação Pública, no que tange os tipos de mensagens institucional e de gestão recebeu algum investimento, mas ainda está aquém dos desafios impostos pela lógica liberal, no contexto de hegemonia neoliberal.

A ausência de uma comunicação de governo direcionada ao cidadão que faz uso da Assistência Social ficou engolida pelo programa de transferência de renda Bolsa Família, em decorrência do alcance, e, por ser uma novidade, tem impactado nas ações e na dinâmica do sistema, uma vez que é função da comunicação de governo "a busca de legitimação da gestão estatal”, como afirmaram Gil e Matos (2013, p. 100).

A incapacidade do Estado em "trabalhar com a informação voltada para a cidadania" (Matos, 2009; Brandão, 2009) realizando contrapontos, inclusive aos programas sensacionalistas que usam das manifestações da expressão da questão social para aprofundar o preconceito sobre a pobreza, remete para a necessidade da democratização da comunicação no país. A ausência de vontade política das últimas gestões federais, em que pese alguns movimentos no governo Lula em enfrentar o monopólio das comunicações, tem afetado o direito à comunicação da sociedade em geral e em especial dos usuários da Assistência Social, permitindo que a mídia, como expressou a ex-assessora de comunicação do MDS, Adriana Moraes, atue como um partido político sem o ônus deste.

A comunicação de governo é uma aliada da Comunicação Pública na medida em que esta organiza e publiciza a informação sobre a política, dando ciência e prestando contas à sociedade em geral sobre as ações realizadas, além de evidenciar uma posição política inerente a uma sociedade democrática. A partir desse posicionamento que gera transparência, abrem-se as possibilidades para que a Comunicação Pública atue com o objetivo de reduzir as diferenças de compreensão da realidade, uma vez que é de sua natureza o diálogo pedagógico mediado pelo interesse de fortalecer a democracia e a cidadania. Esse cenário remete à relação dos técnicos com a comunicação junto aos usuários, que de acordo com eles representa na atualidade o maior desafio da Assistência Social. 


\subsubsection{Os técnicos e a Comunicação Pública nos Cras}

De acordo com os técnicos nos Cras, é muito difícil "transmitir o que somos na Assistência Social para os usuários e fazer com que o usuário reflita e saiba que ele está acessando um serviço de assistência social, e não um programa de outra secretaria" (Técnica do Cras 1 de Tobias Barreto/SE). Assim, para qualificar essa interlocução, os técnicos produzem informações do tipo institucional, que orientam sobre a estrutura, as atribuições e o funcionamento do Cras e da Assistência Social, indicando os direitos e deveres do usuário. Todos os Cras visitados possuem material gráfico, como se pode ver nas imagens abaixo (Figuras 11 e 12), sempre elaborado pela própria equipe com o apoio do nível central para a reprodução, ${ }^{89}$ de forma que esse recurso de comunicação seja entregue no primeiro contato com o usuário.

\section{Figura 11}

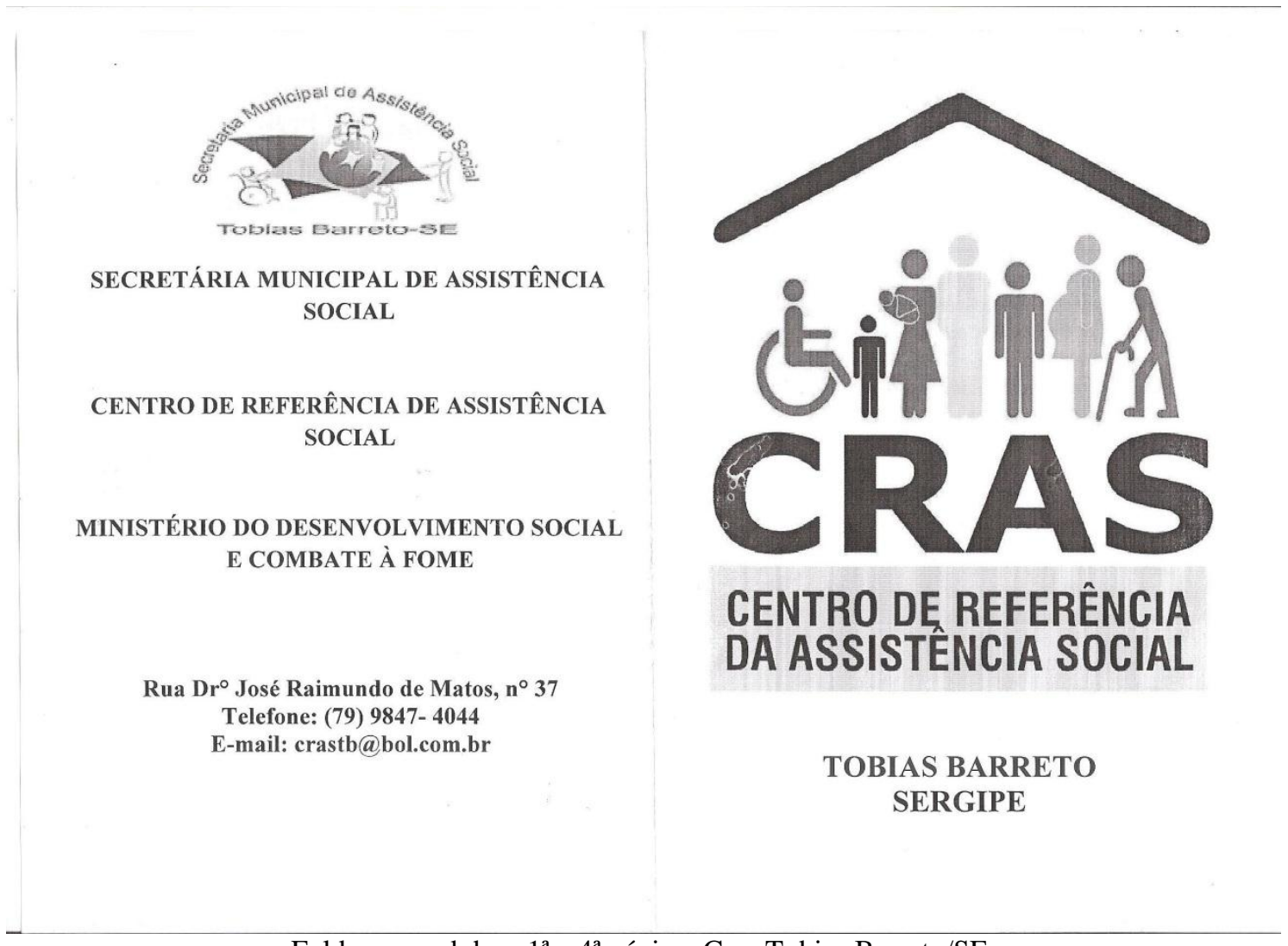

Folder, uma dobra. $1^{\mathrm{a}} \mathrm{e} 4^{\mathrm{a}}$ página. Cras Tobias Barreto/SE.

\footnotetext{
${ }^{89}$ As elaborações de materiais gráficos, páginas na rede social Facebook, faixas e outros são sempre realizadas pelos técnicos em processos de discussão coletiva interna. Dedicam um tempo a esse serviço. Por vezes, contam com um familiar ou uma pessoa conhecida, com habilidades com materiais gráficos, que colabora prestando um trabalho voluntário.
} 


\section{Figura 12}

\section{ATIVIDADES DESENVOLVIDAS}

- Atendimentos Psicossocial

- Visitas Domiciliares:

- Elaboração de Estudos e Relatórios Psicossocial;

- Encaminhamentos dos usuários aos Programas, Projetos e Serviços existentes;

- Encaminhamento de pessoas com deficiência e idosas ao Benefĩcio de Prestação Continuada - BPC;

- Reuniões Comunitárias;

- Palestras e Oficinas Socioeducativas;

- Serviço de Proteção e Atendimento Integral à Família PAIF.

\section{EQUIPE TÉCNICA}

- Assistentes Sociais Elaine Conceição Feitoz Milena Priscila Alves de Góes Rita de Cássia Gomes de França Norma Izabel Santos Alcântara

- Psicólogos

Charles Vinicius Bezerra de Souza

- Coordenadores:

Amanda Regina Fraga Santos Rodrigo Firmino Alves Santos

Auxiliar Administrativo: José Davi Ferreira Santos Recepcionista:Janoelson Batista de Santana

\section{O QUE É CRAS}

É uma unidade pública estatal descentralizada da política de assistência social, responsável pela organização e oferta de serviços da proteção social básica do Sistema Único de Assistência Social - SUAS, nas áreas de vulnerabilidade e risco social dos municípios.

Caracteriza-se como a principal porta de entrada do SUAS, sendo uma unidade que possibilita o acesso de um grande número de famílias a rede de proteção social de assistência social.

\section{OBJETIVO}

Prevenção de ocorrências de situações de vulnerabilidades e risco social no município por meio do desenvolvimento de potencialidades e aquisições, do fortalecimento de vínculos familiares e comunitários e da ampliação do acesso aos direitos de cidadania.

\section{PÚBLICO ALVO}

- População em situação de vulnerabilidade social decorrente da pobreza, ausência de renda, acesso precário e rede de serviços e garantia de direitos;

Famílias beneficiárias do Programa Bolsa Família em descumprimento das condicionalidades;

Beneficiários (as) do Benefício de Prestação Continuada $\mathrm{BPC}$;

Folder, com uma dobra. $2^{\mathrm{a}}$ e $3^{\mathrm{a}}$ página. Cras Tobias Barreto/SE.

Esse material funciona como um suporte ao trabalho de escuta que se realiza no cotidiano, sendo um desafio constante, uma vez que o usuário nem sempre apresenta a demanda de imediato, requerendo a dedicação de um tempo para que ocorra interação e confiança junto ao técnico. Outro desafio diz respeito ao uso de uma linguagem na justa medida, ou seja, aquela capaz de entrar em ressonância com as preocupações, com a situação, com a cultura e com o vocabulário do usuário.

O básico do nosso trabalho ele passa por uma transformação e transformação se faz através de informações, né? Nós temos a dificuldade de repassá-las. [...] Acho que a falha está na gestão dos técnicos no diálogo do dia-a-dia com o usuário mesmo. [...] Essa questão da comunicação vai muito da fala do técnico com o usuário e como são pessoas em extrema vulnerabilidade social e a questão de pouco estudo fica muito complicado porque às vezes o técnico vai muito técnico e aí não usa esse cuidado e é a questão que a gente tem falado nos grupos e me colocam mais usuária do que técnica porque às vezes falo muito a linguagem popular para que eles entendam. (Técnica do Cras 2. Tobias Barreto/SE)

Na concepção de Zémor (2009), o diálogo é considerado como uma atitude de serviço público e exige um mediador qualificado, igualmente identificado, capaz de estabelecer relações entre a administração e o usuário, a fim de receber a demanda, qualificá-la, apontando as possibilidades de encaminhamentos. Nesse caso, não se 
registrou, por meio de nossa observação, o uso de crachás que identificasse o técnico, e sim o uso de uniformes, sendo que, nos Cras, os usuários são acolhidos na recepção e, em seguida, encaminhados para o assistente social e/ou psicólogo, quando se identifica uma demanda que requer uma escuta qualificada.

Alguns Cras criam estratégias cotidianas de abordagem coletiva com a finalidade de apresentar o equipamento e a política, conforme podemos constatar na fala de uma técnica do Cras Ribeirinho, em Santarém:

\begin{abstract}
Essa acolhida é logo cedo quando a gente chega aqui. Logo que chego já tem vários usuários a gente no inicio faz um folder e entrega pra todos eles e levamos informações pra eles sobre o Cras e isso é feito todos os dias, entendeu? eles pensam que o Cras é só o Bolsa Família e aí é o momento de formalizar essa informação para eles. Eles entram e a gente faz aquela acolhida toda oferecemos um cafezinho e damos boas vindas. (Técnica do Cras Ribeirinho. Santarém/PA)
\end{abstract}

As reuniões do Paif ocorrem, em geral, uma vez por mês, com a definição dos temas desenvolvidos nessas reuniões sendo feita em conjunto com os usuários. Dentro de uma reunião se pensa o próximo assunto ou uma sequencia de assuntos. Isso, a princípio, seria o suficiente para atrair a participação, mas não é assim que ocorre. Para estimular a participação dos usuários nas reuniões do Paif, alguns Cras realizam os encontros de forma descentralizada. Por meio de parcerias com escolas, associações de bairro, entre outros equipamentos, buscam, com o apoio das lideranças locais, mobilizar as pessoas daquele entorno para participarem da reunião temática. Outros Cras condicionam o ingresso do usuário em oficinas, em cursos e em demais serviços ofertados pelo Suas à participação nessas reuniões, sob o argumento de que, como a Saúde e Educação são condicionantes à permanência no Programa Bolsa Família, participar do Paif é a condição da Assistência Social. Outras equipes de Cras investem na adesão em decorrência de empatias dos usuários com o tema.

Para alguns Cras, é importante telefonar para o usuário para lembrá-lo da reunião, em que pese, na opinião de quase todos os técnicos, trocarem excessivamente o número do celular. Além do telefonema, é comum entregarem, ao final do encontro, um lembrete com a data e o horário da próxima reunião, como se pode ver na figura 13 . De acordo com os técnicos:

Fazemos contato por telefone celular que tem um bom alcance. Eles sempre mudam o número do celular. Em cada reunião a gente tem que estar reforçando o mesmo celular para ter contato. A gente telefona, avisa e a gente já tem essa dinâmica com eles. Fazer a reunião e já deixar agendado e assim vai fluindo e mesmo assim antes da reunião a gente e dá uma ligadinha. A 
gente faz os lembretes e naquela reunião já deixa agendado a outra, mas mesmo assim a gente reforça o convite e por isso é que eu acho que está fluindo. E a gente peca um pouco em não divulgar o que a gente faz. Se tivesse um profissional a gente divulgaria mais. (Técnica do Cras Menino Jesus. São Gabriel/RS)

Então a gente deixa a convocação para que ele (usuário) compareça e nós temos os parceiros que são os lideres comunitários, os representantes, os agentes comunitários de saúde, as equipes do PSF. Eles acabam sendo nossos parceiros na comunicação. Como as reuniões do PAIF são descentralizadas ocorrem todas lá nas comunidades, não temos uma que seja aqui na se para a facilidade mesmo do acesso porque tem a questão do deslocamento para a sede e então para eles é nas comunidades e a gente fecha as parcerias, as comunicações com os espaços disponíveis da rede. Se tiver trabalho de convivência e fortalecimento de vínculos no povoado, no assentamento e a gente usa o espaço do serviço para fazer a reunião ou palestra. Nessa formação de cidadãos a gente faz sempre articulado com a rede, a exemplo do Programa de Saúde na escola com as questões sobre drogas, sexualidade, gravidez na adolescência. (Técnica do Cras 1. Tobias Barreto/SE)

Figura 13

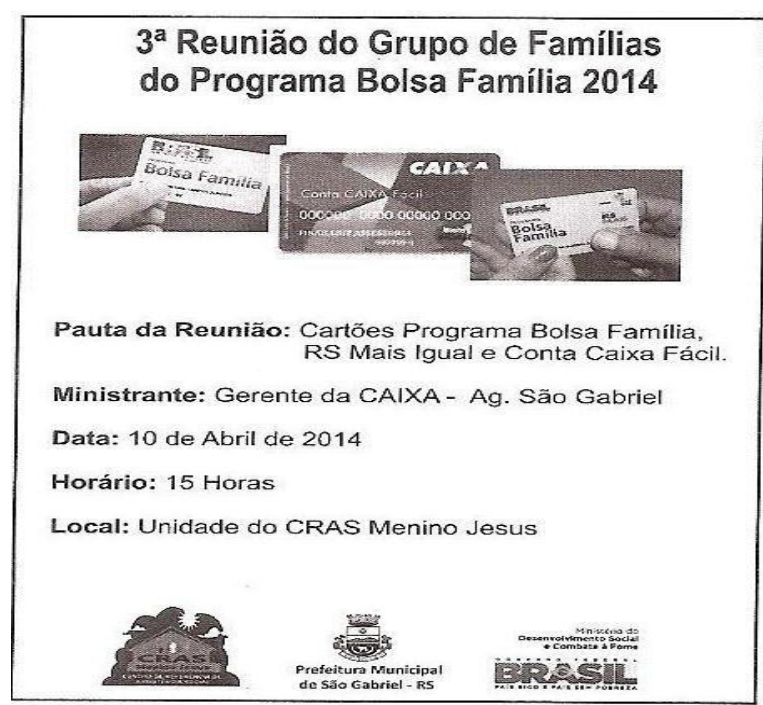

Lembrete da próxima reunião. Cras Menino Jesus, São Gabriel/RS.

Essas estratégias para assegurar a presença do usuário nas reuniões do Paif revelam concepções técnico-ético-políticas dos técnicos que, no contexto da correlação de forças presente na Assistência Social, reeditam com algumas práticas o mito fundador. Com base no depoimento de uma técnica do Cras Havaí/Ventosa, em Belo Horizonte, assegurar a participação dessas pessoas é um grande desafio, sendo necessário conjugar tema, horário, local e outras subjetividades nem sempre identificáveis pelos técnicos. Portanto, há uma necessidade de se criar estratégias para mobilizar os sentimentos e o interesse dessas pessoas, além das questões objetivas. O desafio para a superação desse limite está na forma de corresponsabilizar o sujeito no 
seu processo de inclusão. Ao não se construir essa diferenciação, termina-se recorrendo às velhas práticas, como, por exemplo, o clientelismo e o paternalismo.

Alguns técnicos questionam sobre a construção dos temas para as reuniões do Paif uma vez que reconhecem, de acordo com as normativas, esse espaço para trabalhar o usuário como protagonista da política. $\mathrm{O}$ entendimento dos técnicos é de que trocar informação com o usuário é fortalecê-lo para que ele próprio reivindique os seus direitos. Acreditam que o protagonismo tenha de ocorrer com a participação dos usuários no planejamento, na execução e na avaliação da política, e não na definição de temas que abordam o direito, uma vez que essa perspectiva funciona muito mais como comunicar sobre algo do que construir a consciência sobre os direitos, como se pode verificar no depoimento em entrevista do técnico em Belo Horizonte.

\begin{abstract}
O que mais vemos é a dificuldade que os profissionais vivenciam em relação à Politica de Assistência Social no campo com o usuário é: qual a oferta que vamos afiançar a este usuário? Porque geralmente quando vamos comunicar com o usuário não é numa perspectiva de trazer protagonismo, participação. Inclusão de processos e seriam processos mais democráticos e processos de escolha. Mas, não. É pra dar a ele o comunicado de algum programa ou alguma ação governamental que ele cumpriu ou descumpriu. Se a proteção social básica cumprisse o seu papel de trazer um processo de construção da consciência sobre direitos, sobre acesso aos direitos, sobre o não acesso e o porquê do não acesso seria contra hegemônico. Falar de protagonismo do usuário é falar que ele tem de participar tanto do processo de elaboração da política, da execução e avaliação. Se você não consegue atrair o usuário o processo de planejamento aí você tem que ver como é que você comunica para que haja um entendimento do que é a política. Você não vê nas normativas a discussão sobre comunicação. Você vê sobre orientação social. O protagonismo é vinculado ao controle da política, mas também é importante controlar a construção dessa política. No Caderno 2 do PAIF fica explícito quando ele vai responder as ações comunitárias e aí ele vai articular isso com a acolhida, ele vai falar assim: 'fornecer um conjunto de informações relacionadas ao serviço.' Então ele se concentra nisso. Não acho que temos feito pelo ao menos isso. (Técnico da Gerência de Coordenação da Política de Assistência Social de Belo Horizonte/MG)
\end{abstract}

Há, ainda, uma questão apontada por alguns técnicos entrevistados para essa pesquisa sobre as parcerias desenvolvidas pelo Cras junto a algumas lideranças comunitárias para a mobilização das reuniões do Paif e atividades comunitárias. No entendimento desses técnicos, essa ação sem uma reflexão crítica colabora por fortalecer junto aos usuários o clientelismo, exatamente por permitir uma associação por vinculação direta entre o Cras e a liderança, que muitas vezes se sustenta enquanto tal por meio de práticas autoritárias e conservadoras. Outra parceria desenvolvida sem criticidade, e que mantém a Assistência Social vinculada à moral cristã, é aquela realizada com setores religiosos no trabalho educativo, a exemplo das meninas de 12 a 
15 anos e senhoras de 40 a 50 anos grávidas, em Santarém, que participam de palestras realizadas pela igreja, e não por profissionais da saúde pública. O apontamento sobre a ausência de criticidade acerca da história e das concepções que transitam na Assistência Social por parte de alguns trabalhadores sociais faz com que o reordenamento da Assistência Social não altere as relações com o usuário, mantendo-se o favoritismo, o privilégio, o poder de persuasão, de mando e a moral cristã, como se pode averiguar abaixo, nas entrevistas de alguns técnicos.

O que me instiga é que um dos elementos que contribui, mas ao mesmo tempo pode prejudicar a política de comunicação direta com o usuário é a cultura política do território. A comunicação no território, as forças políticas do território por vezes elas contribuem como, por exemplo, a liderança. A comunicação da liderança no território às vezes é mais eficiente do que a comunicação do serviço, a Comunicação Pública. (Técnico da Gerência de Coordenação da Política de Assistência Social de Belo Horizonte)

Eu acho que a comunicação aparece quando a gente vai fazer o nosso planejamento mensal e vai fazer atividade em grupo. O grupo do PAIF vai trabalhar este mês a temática de métodos contraceptivos ou vai trabalhar a temática família, laços e ai como a gente tem que chamar esse povo? Tem que ligar pra quem? Vai ter que pedir para agente comunitária avisar, entregar os convites para as equipes. D. Maria da comunidade vai ter que entrar em contato com ela e é isso. Eu acho que a comunicação aparece no planejamento mensal. (Técnica do Cras 1. Tobias Barreto/SE)

Eu trabalhei muito com as associações de bairro, direcionado ao presidente, agente comunitário. [...] Então quando a gente se aproximou dos presidentes de bairro e nosso trabalho deu uma subida muito grande porque ficamos mais próximos mesmo da população. [...] Quando a gente quer fazer essas ações tem a parceria com os presidentes do bairro. $\mathrm{O}$ presidente na reunião da associação dele eles já divulgam e o boca a boca. (Técnica do Cras Urumari. Santarém/PA)

A questão dos fundamentos religiosos que é um passo atrás a tudo que fizemos em conceituação. Então temos vários embates. (Técnica do Cras 2. Tobias Barreto/SE)

Em Rubiataba/GO, as técnicas entrevistadas apontaram que consideram que os usuários não compreendem ainda a política de Assistência Social e elencaram três aspectos culturais típicos em seus comportamentos: "o comodismo; o assistencialismo e a corrupção". Mas, por meio da fala, percebe-se também que a diferença entre direito e privilégio não é algo tão resolvido assim para elas teoricamente.

O comodismo também está bem voltado pra eles né? [...] Ainda estão muito impregnados com o assistencialismo e quando começamos a falar de direito eles oh... Ou então quando vem o direito você tem que explicar que não é daquela forma. Você tem o direito, mas também tem o dever. Privilégio e direito são coisas importantes né? (Técnica do Cras. Rubiataba/GO) 
As parcerias no Cras ocorrem também junto às instituições públicas e privadas, com equipamentos públicos estatais que atuam no território. Essas parcerias possibilitam realizações de campanhas e intervenções conjuntas, como as duas campanhas de informação de interesse geral encabeçadas pelo MDS que acontecem anualmente, que são: a campanha de combate a exploração sexual de crianças e adolescentes, no dia 18 de maio, e a campanha de combate ao trabalho infantil, em 12 de junho. Além disso, alguns Cras desencadeiam outras campanhas, como em Tobias Barreto, sobre os direitos dos idosos e sobre a participação da Assistência Social no desfile de Sete de Setembro.

A gente produz material de campanha. Nós temos a produção de material que é divulgação, né? Tem que ter um toque porque não é só entregar a panfletagem. A gente tem que pensar que são coisas lúdicas que tem que atrair e não ser muito longas. Tem algumas reuniões que avisamos com o carro de som, ou mesmo vai de casa em casa avisando que vai ter reunião. Temos a campanha dos idosos e recentemente dialogamos com a população e de forma diferente que aqui tem uma tradição que a assistência tem que sair no desfile do Sete de setembro. A gente sempre tem procurado por aqui os temas sociais e leva isso para a avenida. Aqui fazemos também a campanha do MDS do trabalho infantil e combate a prostituição infantil. (Técnica do Cras 2. Tobias Barreto/SE)

No ano passado fizemos flyers e fomos em cada território. Cada equipe ficou uma parte. As pessoas que encontrávamos na rua nós conversávamos e os outros fomos colocando na caixinha do correio. Com um crachá e um colete do Cras. Era laranja. Cinco técnicos, uma estagiária e nossa recepcionista. (Técnica do Cras Havaí/Ventosa. Belo Horizonte/MG)

Sobre a questão financeira, os técnicos comentam que não há fonte orçamentária e nem recursos diretos para uma política de comunicação que permita campanhas ou outros materiais mais elaborados. Contam com o suporte orçamentário do gestor municipal ou do próprio Paif, que advém do governo federal.

A questão de um orçamento fixo e o recurso que temos para essas campanhas no município não são muitos e para você pagar um designer gráfico ou um jornalista você vai acabar diminuindo o seu trabalho e então os técnicos acabam se tornando gráficos. Tem um menino que trabalha na secretaria que dá uma melhorada. Quem monta é a secretaria mesmo. (Técnica do Cras 2, Tobias Barreto/SE)

Dentro da secretaria de comunicação tem um orçamento vinculado a GPAS para as festas, publicações, mas não são exatamente voltadas para os usuários. [...] O nosso aqui dentro da proteção social básica você não tem um orçamento específico para isso. [...] Você não tem dentro do orçamento que é repassado para o Cras ou algo que é específico só para a questão da mobilização, eventos ou comunicação. [...] Anualmente nós desenvolvemos um plano de ação com o Cras que é o que faz planejamento de todas essas atividades. Dentro dessas atividades à medida que surge a demanda a gente vai se organizando para estar atendendo. Normalmente a gente repassa um valor para o Cras para a gente estar desenvolvendo as atividades do PAIF que 
é 14 mil e são esses 14 mil para desenvolver todas as ações do planejamento do Cras. (Técnicas da Gerência de Coordenação da Proteção Social Básica de Belo Horizonte/MG)

A gente tem o recurso do governo federal que às vezes quer fazer uma divulgação das atividades que vai fazer e a gente pode estar utilizando o recurso do governo federal. (Técnica do Cras Menino Jesus, São Gabriel/RS)

Com restrições de recursos financeiros e sem acesso direto a profissionais de comunicação, alguns técnicos apontam dificuldades para desencadear ações dessa natureza que às vezes são sugeridas de forma hierarquizada, do gestor para os técnicos, e nem sempre o tema escolhido e/ou a forma desenvolvida é capaz de sensibilizar o usuário, como aponta uma técnica em Belo Horizonte.

Eu acho um esforço muito grande uma atividade coletiva. Quando consegue a gente começa pequeno e só depois que começa que um chama o outro. Muitas das metas, das coisas que são traçadas vêm de cima para baixo, né? Tem campanha disso e daquilo, tem que mobilizar, trazer o usuário e às vezes o usuário não quer aquilo. (Técnica do Cras Havaí/Ventosa, Belo Horizonte/MG)

Em Belo Horizonte, há um grupo chamado Núcleo de Mobilização Social ${ }^{90}$ (MOBS), constituído por quatro atores que se ocupam em traduzir, por meio da expressão artística e lúdica, questões afins à Assistência Social e aos direitos sociais (Foto 11). Há, no entanto, algumas problematizações por parte dos técnicos quanto ao papel do MOBS, que, até o momento, atende as demandas mais centrais do órgão gestor, sendo que atualmente existem 33 Cras no município com demandas para o trabalho nas comunidades. Há um impasse entre uma demanda expressiva e uma estrutura que só consegue atender demandas pontuais. Ao que tudo indica, o MOBS não

\footnotetext{
${ }^{90}$ O Núcleo de Mobilização Social (MOBS) foi criado em meados de 1998, sendo somente no ano de 2000 que o setor se organizou efetivamente e passou a ser constituído por 12 profissionais, sendo estes: assistente social, jornalistas, atores, educadores artísticos, publicitário, historiador, consultor em artemobilização. Recebeu essa denominação na secretaria de Assistência Social da Prefeitura de Belo Horizonte por agregar as funções clássicas de uma assessoria de comunicação e ainda ter por como meta a mobilização social em torno dos temas da Assistência Social. À época foi definido como missão: "contribuir para que a política de Assistência Social do município de Belo Horizonte seja mais acessível e inclusiva, desenvolvendo ações comunicativas, atividades educativas e intervenções mobilizatórias que possibilitam a ampliação da visibilidade dos programas, projetos e serviços da SMAS através da informação, articulação intersetorial e da sensibilização social” (Mobilização Social, 2001, memo). As ações do MOBS de davam por meio de duas grandes frentes: uma direcionada diretamente ao cotidiano da secretaria municipal de Assistência Social, tendo por objetivo dotar o trabalho técnico de recursos de linguagens que colaborassem para uma interlocução mais acessível com o usuário e a sociedade em geral e outra relacionada à construção de uma agenda de visibilidade da secretaria, com vistas a ampliar a sua inserção no imaginário da cidade, por meio de espaços inclusive na mídia. Os dados de 2003 indicam que o grupo de teatro realizou 30 atividades artísticas pedagógicas distintas e esteve presente em 36 eventos apresentando para um total de 25 mil pessoas. Ainda nesse mesmo ano, produziram 21 eventos, apresentando para 20 mil pessoas aproximadamente. Ao longo desses anos ocorreram duas reformas administrativas na prefeitura de Belo Horizonte, mas o MOBS não entrou no organograma oficial da secretaria de Assistência Social.
} 
foi incorporado à dinâmica do Suas e termina por se comportar como uma assessoria de comunicação no nível central. 


\section{Foto 11}

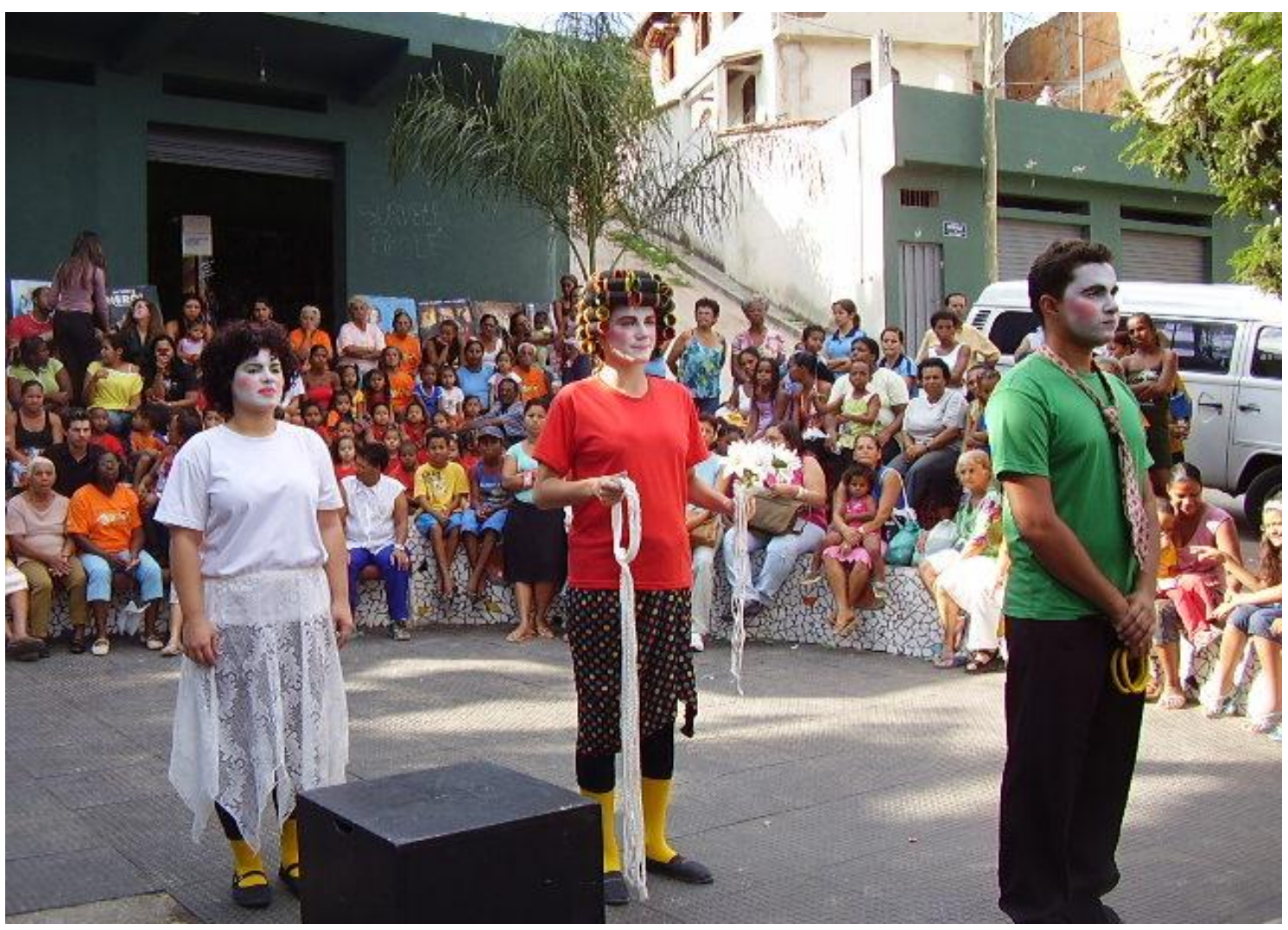

Grupo de Teatro de Mobilização Social (MOBS) apresentando à uma comunidade o que é o Cras. (2009). Foto: Arquivo MOBS/PBH.

Em todos os Cras visitados existem murais informativos, como sugere as normativas, sendo todos criados e mantidos pela própria equipe de referência. No entanto, há alguns técnicos que problematizam o efeito desse instrumento, considerando que não dominam técnicas de comunicação visual, entre outros conhecimentos necessários. Oportunizam para problematizar que os profissionais de comunicação também não têm uma qualificação que permita uma contribuição mais efetiva para a área, demonstrando que esse vácuo constitui tanto a realidade no âmbito municipal quanto federal, como narrou a diretora do departamento de gestão do Suas.

[...] Às vezes penso em colocar data, horário e local em vermelho e que assim eles vão prestar mais atenção, mas isso é o que a gente acredita que vai funcionar, mas há pessoas que estudam isso e sabem como chamar a atenção, né? Então parte do que a gente acredita. Não fomos capacitados pra isso. Por isso acho que tinha que ter uma capacitação casada. A gente tinha que ser capacitado junto com eles (profissionais da comunicação) porque eles também não dão conta de atender nossa demanda. Porque estando em um nível central eles não tem essa leitura do território. Então precisa casar a nossa experiência com a deles. (Técnica do Cras Alto Vera Cruz. Belo Horizonte/MG) 
Nos municípios de São Gabriel e Rubiataba, os técnicos dos Cras criaram uma página na rede social Facebook. Essa experiência, porém, não se estende aos demais Cras, uma vez que, de acordo com os técnicos, além da falta de recursos financeiros e de acesso a profissionais de comunicação, o que compromete a fluidez da comunicação junto aos usuários, assim como com a sociedade em geral, é a hierarquia na instituição, como apontaram os técnicos em Santarém e Belo Horizonte.

\begin{abstract}
Sobre a comunicação entre os técnicos e gestores aqui é hierarquizado, né? Aqui os técnicos precisam falar comigo e aí temos a coordenadora da proteção social básica do município e então ela coordena tudo o que é da proteção social básica, ou seja, os Cras e os outros programas que estão dentro dessa proteção. Os coordenadores de Cras já chegam com ela. Ela tem acesso com a secretária e com o MDS. Pode passar e-mail em toda situação que tiver. É hierarquizado, mas a comunicação funciona sim. Temos aqui no nosso município a gestora que é a nossa secretária de assistência social (primeira-dama) ela é muito aberta, mesmo quando o próprio coordenador de Cras precisa conversar com ela. Não é só com quem está lá próximo não, ela gosta de visitar os Cras e ouvir o que está acontecendo com o Cras também. (Técnica do Cras Ribeirinho. Santarém/PA)
\end{abstract}

Temos que usar várias formas, usar a criatividade para chegar a esse público. Mas a gente não pode criar blog, tudo tem que está lá tem que passar pela comunicação. [...] Quando a gente precisa de cartaz a gente comunica com a regional e eles remetem para a central. Às vezes é cartaz para evento e quando chega já passou a data. A gente as vezes corta caminho e chega direto a central sabe? Mas a gente sabe que não pode fazer. [...] $\mathrm{O}$ acesso da comunicação tanto no nível central como regional tudo é muito burocrático e muito moroso. Eu acho que quando a gente tá aqui no território a gente precisa de agilidade em todas as nossas ações. (Técnica do Cras Alto Vera Cruz. Belo Horizonte/MG)

Os Cras utilizam muito aquela lógica de fazer mural que eles não são visualmente muito bacanas assim, mas com relação a oferta de qualificação do usuário eles falam: ah eu pensei que o mural estava atualizado. É o que funciona e é o que você vai colocar tanto a oferta da prefeitura como a apresentação de um jornal que não é todo Cras que tem. (Técnica da Gerência de Coordenação da Proteção Social Básica de Belo Horizonte/MG)

A questão da hierarquia tem um impacto no trabalho dos técnicos e, consequentemente, na comunicação com os usuários e com a sociedade em geral, principalmente em instituições de grande porte, como é o caso de Belo Horizonte, que é uma metrópole. Lá, foi criada uma fan page com a participação de adolescentes entre 16 e 17 anos, usuários da Assistência Social, com o acompanhamento da assessoria de comunicação do órgão gestor. No entanto, esse canal de comunicação não foi reconhecido pela assessoria de comunicação do governo municipal, como narra o técnico coordenador da gerência de coordenação da política de Assistência Social. 
adolescente é o Pro Jovem que tem no Facebook. Então o Pro Jovem tem uma fan page que são adolescentes de 16 e 17 anos que participam e tem a assessoria de comunicação e um estagiário exclusivo para isso. Não está no site da prefeitura. Ele foi autorizado pela assessoria de comunicação, mas ele não está institucionalmente vinculado ao instrumento principal de comunicação da prefeitura. E aí tem um núcleo que é o coletivo dos jovens. É tipo um conselho da juventude, um conselho dos jovens onde eles discutem como vão ser as atividades. (Técnico da Gerência de Coordenação da Política de Assistência Social de Belo Horizonte)

Com base no exposto, percebe-se que os processos comunicativos instituídos entre os técnicos e os usuários são constituídos por várias estratégias que refletem a dualidade de concepções que sustentam a correlação de forças presentes na Assistência Social. Estão presentes tanto aqueles que consideram que o Estado deve agir pelo dever de informar quanto aqueles que reeditam o clientelismo e o pensamento conservador.

As condições analisadas no âmbito da totalidade da comunicação na Assistência Social têm sido determinantes para o improviso realizado pelos técnicos, sendo que algumas ações comprometem a dimensão ética da Comunicação Pública, uma vez comprometida com o interesse público, "sem a qual ela deixa de existir enquanto conceito" (Kçouski, 2013, p. 54).

A questão, destacada por Boschetti (2003), de que o (não) trabalho tenciona a assistência como política governamental, existindo um movimento circular que impede aqueles que têm trabalho de acessar direitos e, concomitante, marginaliza os que não têm trabalho ocorre também em relação ao messianismo e ao voluntarismo. Ao mesmo tempo em que a instituição da Assistência Social como política pública quer dizer o rompimento com essas práticas, no geral é exatamente por meio dela que os técnicos asseguram aos usuários o acesso à informação e à comunicação.

Percebe-se, com base na concepção dialética - que requer pensar a realidade como um conjunto articulado de partes -, que as condições de trabalho asseguradas aos trabalhadores sociais que operam o sistema são as mesmas ofertadas aos trabalhadores que utilizam o sistema, sendo estas determinadas pelo neoliberalismo. $O$ fato de a maioria desses trabalhadores serem mulheres agrava esse cenário, o que traz à tona a questão de gênero e sua relação com o mercado de trabalho, problema tão denunciado por pesquisadores e pelo movimento feminista. ${ }^{91}$

\footnotetext{
${ }^{91}$ De acordo com pesquisa apresentada no Fórum Econômico Mundial, ocorrido na terceira semana de novembro de 2015, o Brasil ficou na $133^{\mathrm{a}}$ posição, ou seja, é o segundo pior, à frente apenas de Angola, em relação à igualdade de salário entre homens e mulheres, segundo o Índice Global de Desigualdade de Gênero. Disponível em: <http://economia.uol.com.br/noticias/redacao/2015/11/22/brasil-e-penultimoem-ranking-de-diferenca-de-salarios-entre-homem-e-mulher.htm>. Acesso: em 22 nov. 2015.
} 
Um determinante que também produz impacto nos processos comunicativos e na Comunicação Pública nos Cras são os efeitos da precarização da formação profissional $^{92}$ dos técnicos. A inconsistência teórico-metodológica compromete as análises críticas e fortalece, entre outras práticas conservadoras, o messianismo e o voluntarismo. Todas essas questões, aliadas ao produtivismo característico desse modelo político e econômico, incidem sobre a cultura da subalternidade, que não é restrita aos usuários, conforme evidenciou Silva (2014).

O Cras, por ser uma unidade pública estatal, deve, na concepção de Zémor (2009), disponibilizar as informações, fornecer as regras do jogo coletivo e prestar contas de seus atos, contribuindo, assim, para as mudanças, tanto as comportamentais quanto as de organização social. Portanto, tem por competência desencadear processos, denominado por Gramsci (2001) como Catarse - que promove a mudança de consciência dos subalternos, facilitada, inclusive, pela relação entre os técnicos e os usuários estabelecida por meio de uma comunicação direta, entendida por Duarte (2009, p. 66) como o "instrumento (que) garante uma aprendizagem mais consistente e um nível de informação adaptado às necessidades do interessado, assim como o feedback tende a ser mais imediato e preciso". Martin-Barbero (2013, p. 273) colabora com a ideia de que os mediadores, compreendidos como os profissionais que atuam nas instituições "fazendo a conexão entre as experiências dos setores populares e outras experiências do mundo intelectual", contribuem com uma nova produção de sentidos e com a cultura popular, sendo o cotidiano fértil por ser um campo de construção histórica e em disputa.

No entanto, as possiblidades de desencadear um trabalho educativo, como sugere as normativas, e assegurar os princípios da Comunicação Pública estão

\footnotetext{
${ }^{92}$ De acordo com Larissa Dahmer Pereira (2008), os primeiros cursos na modalidade à distância (EAD) foram implementados em 2006 e ganharam uma proporção substancial de matrículas. Em 2009 52,3\% das matrículas nos cursos de Serviço Social já eram na modalidade EAD, elevando o Serviço Social ao terceiro maior curso ofertado nessa modalidade pelo país. Em viagem por algumas cidades no Vale do Jequitinhonha, em Minas Gerais, em junho de 2015, observou-se várias faixas informativas de uma instituição privada de ensino ofertando o curso de Serviço Social por 149,00 reais a mensalidade. A mesma instituição está com comercial na televisão, visto no dia 29/11/2015, no canal da TNT. Existem vários estudos e denúncias realizadas pelos Conselhos Regionais e Conselho Federal de Serviço Social sobre as condições e a qualidade asseguradas por estas instituições, sendo que a fiscalização do MEC é praticamente inexistente uma vez que esta modalidade de ensino faz parte da estratégia iniciada pelos acordos dos diversos governos junto aos organismos internacionais. Três momentos marcantes são identificados na expansão da educação superior no país: i) no regime denominado burguês-militar a educação superior ocupa um privilégio social conferido às camadas dominantes e ganha relevância através do setor privado; ii) no governo de FHC estabelece-se a segunda fase intensificando-se as ofertas de serviços educacionais pelo setor privado e ampliação da privatização interna das IES públicas; iii) o governo Lula reforça o empresariamento na educação e a certificação em larga escala.
} 
comprometidas em decorrência do baixo orçamento para os serviços socioassistenciais; da ausência de uma comunicação de governo para o setor; pelas forças conservadoras que se apoiam no primado liberal; pela incapacidade do governo e da sociedade em democratizar a comunicação no país; pela precarização da formação profissional e do trabalho; pela ausência de profissionais da comunicação nos próprios Cras ou no nível central da gestão da Proteção Social Básica, uma vez que por meio dos depoimentos é perceptível que, dependendo do porte do município, a assessoria de comunicação da secretaria gestora da política de Assistência Social e da prefeitura não dão conta da demanda cotidiana dos Cras . Como afirmou o representante dos usuários do CMAS de Belo Horizonte, "quando eu vejo uma assistente social eu sei que faz por amor. Ganha muito pouco, passam do horário de serviço, mas acontecer não depende só da vontade delas". Nesse sentido, em que pese as adversidades, as contradições, mas também as compatibilidades, é imprescindível conhecer como a mediação realizada pelos técnicos tem impactado os usuários, haja vista que a realidade é dinâmica e contraditória. Afinal, na dinâmica societária tudo é determinante para a superação do ser social.

\subsubsection{Os usuários nos Cras e a Comunicação Pública}

Este bloco tem apresenta, à luz das categorias de análise, como os usuários da política de Assistência Social se comunicam internamente, o que apreendem e como se relacionam com as tecnologias de comunicação. Importa, no entanto, tecer alguns comentários sobre o perfil dos usuários entrevistados nos Cras, em função de suas peculiaridades, uma vez que estes são os brasileiros (não) trabalhadores que, na dinâmica da estrutura econômica e social capitalista, foram excluídos, como apontou Coutinho (2000). São eles os herdeiros, constituídos historicamente, do sentido da colonização, do peso do regime escravista e pela peculiaridade do desenvolvimento desigual e combinado. São as pessoas de "cidadania invertida" (Teixeira, 1989), que não se reconhecem como cidadãos e que se sentem culpados e envergonhados por suas condições, uma vez convencidos historicamente pela moral liberal cristã e pela prática clientelista. Mas são também aqueles capazes de filtrar as mensagens que se dão por meio de mediações, como afirmou Martin-Barbero (2013), e que em suas "experiências (...) revelam movimentos contraditórios: do consenso à rebeldia, do conformismo à resistência, e alguns permanecem legitimando a subalternidade que lhes foi atribuída" (Silva, 2014, p. 165). 
A condição econômica, política, social e cultural mobilizam esses trabalhadores a buscar soluções para as suas vidas, mesmo que na maioria das vezes sejam paliativas. Assim, os motivos para procurarem o Cras são variados, sendo que algumas demandas não têm relação com a Assistência Social, como apontou um líder comunitário em Tobias Barreto, que estava ali no Cras com a expectativa, dentre outras, de que a Assistência Social melhorasse a estrada que dá acesso para a comunidade. Essas demandas de naturezas variadas direcionadas à Assistência Social revelam, do ponto de vista da comunicação, a fragilidade no tipo de informação institucional e na utilização de instrumentos de comunicação massivos, caracterizado por Duarte (2009) pela disseminação de informação para um máximo de pessoas. Revela também as contradições entre as políticas sociais e direitos sociais, considerando-se que a formulação e a execução dos serviços sociais relativizam a perspectiva universal dos direitos sociais, como apontou Behring (2000), burocratizando e focalizando as necessidades.

Muitos usuários procuram o Cras com a demanda de participarem de cursos e de oficinas por considerarem ser uma oportunidade de melhorar o futuro e por possibilitar alterações no mundo do trabalho, mais valorização profissional e mais remuneração. Sentem-se gratificados, prestigiados e otimistas por isso, como nos fala um usuário do Cras Alto Vera Cruz.

No social se você vai numa palestra você aprende a lidar com situações. Mas, o curso em si te traz renda, você se coloca melhor na sua empresa, na carreira melhor, de seu lar, na sua comunidade mesmo. (Usuário 1, em Belo Horizonte/MG)

Os murais informativos existentes nos Cras, percebidos pelos usuários, de acordo com as entrevistas, são os meios que informam sobre cursos e oficinas, sobre as informações relativas ao Programa Bolsa Família e sobre a oferta de empregos. Outros murais, com informações do tipo "utilidade pública", não são lidos pelos usuários. Os idosos justificam-se "ter pouca leitura" ou por enxergarem pouco. Os jovens e os adultos, em geral, ignoram os conteúdos dos murais. Ficam calados, esperando a próxima pergunta da entrevistadora, simulam ter lido ou manifestam que irão ler quando saírem dali. O que se observa é que a possibilidade de se comunicar com os usuários por meio de um instrumento de comunicação segmentado, por ser orientado para grupos de interesse específico em que há maior possibilidade de domínio do conteúdo, acesso, distribuição e retorno dos mesmos, como indicou Duarte (2009), termina por não 
acontecer, constatando-se o amadorismo já publicizado pelos técnicos, conforme se pode verificar nas fotos 12 e 13, abaixo. 
Foto 12

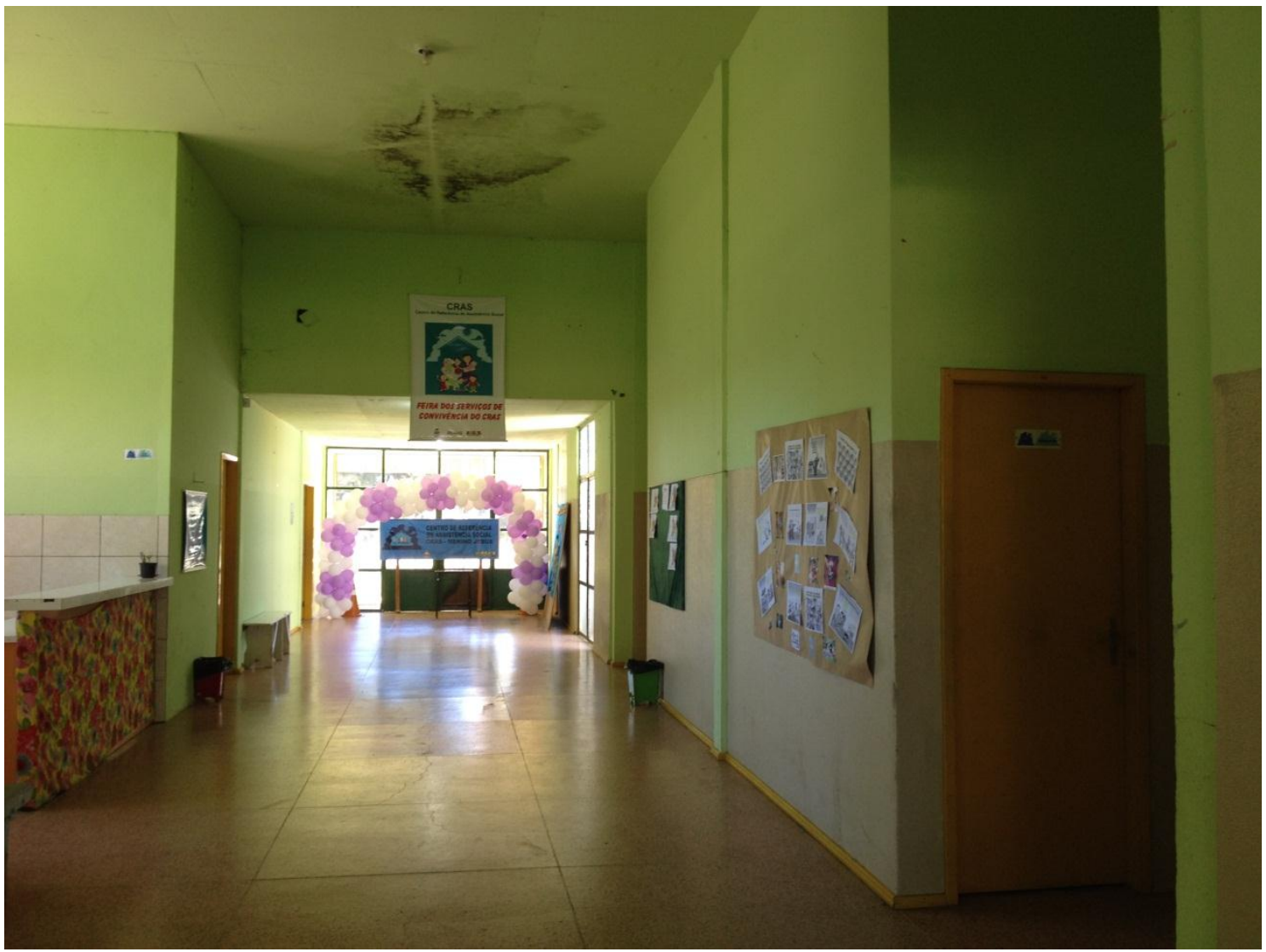

Corredor principal do Cras Menino Jesus. São Gabriel/RS. Foto: Solange Albernaz. Acervo pessoal.

\section{Foto 13}

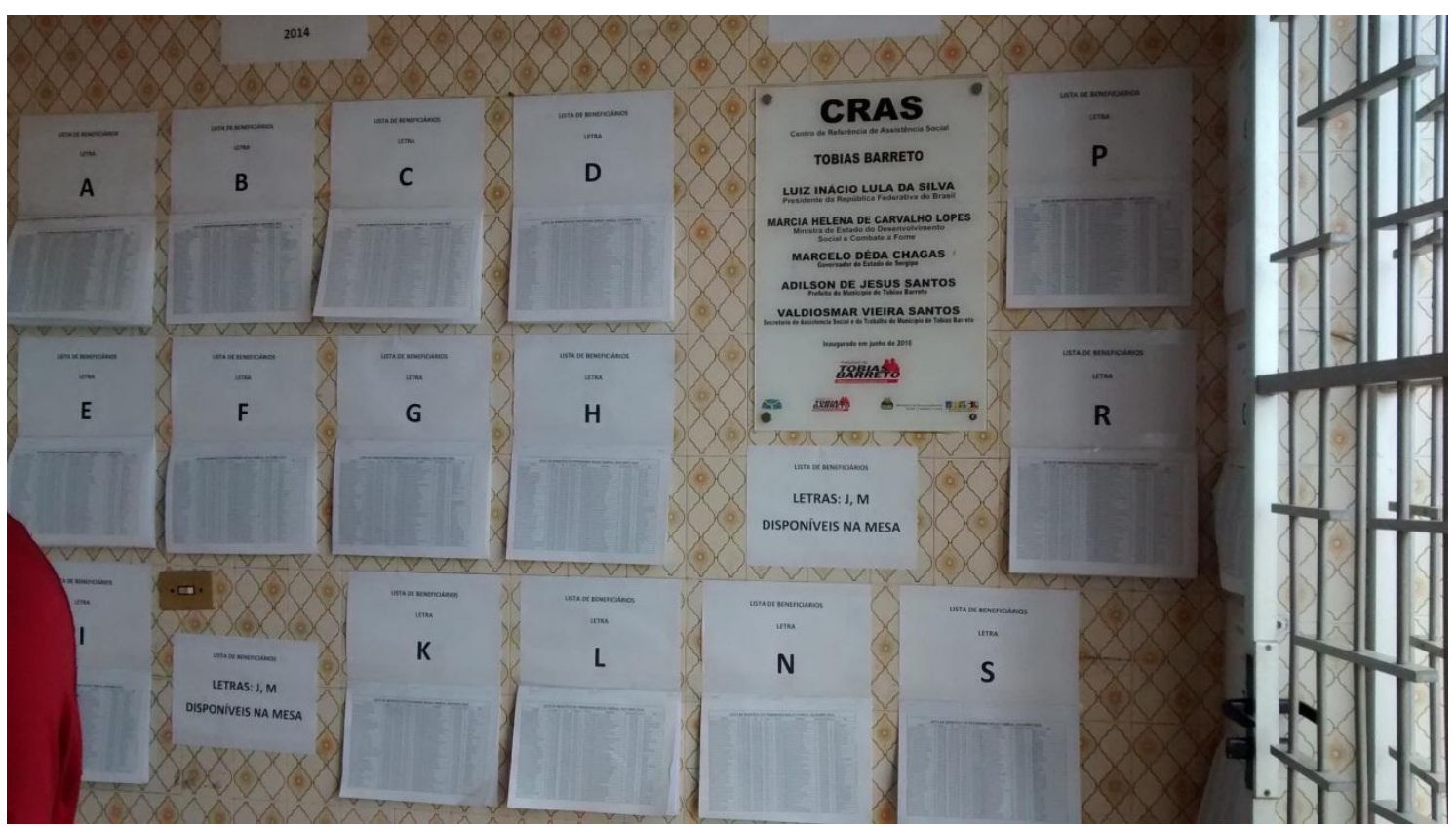

Informativos afixados nas paredes do Cras em Tobias Barreto/SE. Foto: Solange Albernaz. Acervo pessoal. 
Por meio da entrevista, percebeu-se que, por ordem de importância e na linguagem informada por eles, o que esperam resolver no Cras, por ordem crescente, é: o Bolsa Família; prática de oficinas e cursos; registro de documentos; proximidade de casa; o programa de baixa renda para diminuição da tarifa de energia elétrica (documento que atesta que a família está dentro dos critérios para o recebimento do desconto na tarifa de energia elétrica); ajudam quem precisa; conselhos por causa de problemas com filhos na escola; pra não sentir sozinha; e por causa dos passeios. De acordo com uma usuária de Belo Horizonte, a justificativa para se procurar o Cras é:

Porque é um lugar mais perto, atende a gente muito bem, muito bom, todo mundo aqui é excelente com a gente. Muito educado e eficaz. Todo problema venho aqui e sempre que venho tudo é resolvido e tudo de graça. (Usuária 5, de Belo Horizonte)

No geral, os entrevistados estão satisfeitos com o atendimento nos Cras, manifestando agradecimentos afetuosos e personificados aos técnicos. Demonstram, portanto, uma compreensão muito mais estruturada em relações clientelistas do que no entendimento de que o Estado é o único dentre os demais sujeitos envoltos nas dimensões da Comunicação Pública que age pelo dever de informar, uma vez que é no âmbito estatal que ocorre o reconhecimento do direito do cidadão e por meio do qual deve estar assegurado o princípio da impessoalidade (Kçouski, 2013; Matos 2009a).

Contudo, há também aqueles entrevistados em municípios diferentes que indicam uma morosidade do Cras na resolução da demanda, sendo esse problema relacionado principalmente ao Programa Bolsa Família. ${ }^{93}$ Muitos afirmam esperar por meses, e até anos, sem ter alguma informação a respeito. Com dificuldade de acesso a transporte, decorrente das distâncias entre a moradia e o equipamento, além do custo, muitas dessas pessoas, principalmente moradores de áreas rurais e populações ribeirinhas sem telefone próprio ou comunitário, realizam uma epopeia para, em algum momento conseguir, o benefício, o que nem sempre ocorre, como foi presenciado à época da visita ao Cras Ribeirinho, em Santarém.

Uma jovem senhora de etnia indígena, mãe de quatro filhos, acompanhada de duas filhas pequenas, moradora ribeirinha de Cachoeira do Aruã, a doze horas de barco

\footnotetext{
${ }^{93}$ Silva (2012, p. 78) informa que a demanda recebida nos Cras para inserção no Cadastro Único (CadÚnico) é muito maior que o número de contemplados no Programa Bolsa Família, sendo a inserção no cadastro condição para receber o benefício. Muitos municípios apresentam dificuldades para inserir, no CadÚnico, os cadastrados em tempo real, ou seja, em muitos casos, "a ineficiência na gestão do Cadastro e problemas operacionais no Sistema fazem com que indivíduos e famílias esperem por mais de ano para obterem sua inserção no CadÚnico, pois há distintas autonomias na gestão de benefícios e de serviços (o primeiro gerenciado pela esfera federal; e os demais, pela esfera municipal)."
} 
de Santarém, havia saído de sua casa às duas horas da manhã a fim de solucionar o problema que a estava impedindo de receber o benefício há um ano. De acordo com ela, o benefício foi repassado no primeiro mês e depois não o recebeu mais.

Eu vim protestar. Já protestei e agora tem que aguardar. Eu fiz um novo cadastro aqui [...] Não sei o que aconteceu porque fiz o cadastro em agosto (exatamente um ano anterior a entrevista) e eu mandei verificar e quando foi mês de março e quando foi abril e só agora em agosto que eu vim ver. Falaram que não estava nada sendo aceito e eu sai de lá sem saber o que é que está acontecendo. Depois eu voltei lá e ela verificou que não tinha dinheiro (se referindo à Caixa Econômica Federal). Eu vinha na data marcada e nada. Falaram pra eu perguntar e eu sai de lá sem saber o que estava acontecendo porque pelo meu cartão nada está bloqueado. Nos papelzinho vinha dizendo que tava cancelado os pagamento e não sei porque. Amanhã vou lá ver na Caixa Econômica se está lá. Aí não venho mais porque não vou gastar o que eu não tenho e é muito longe. (Usuária 5, de Santarém/PA)

No final daquela tarde, a técnica no atendimento percebeu que havia uma alteração em uma certidão de nascimento de um dos seus filhos e que não foi percebida por quem cadastrou, sendo este o provável motivo do bloqueio. Não se sabe se esse foi o motivo real e se foi solucionado. De qualquer forma, ela deveria passar a noite na cidade (dormem no barco que vieram) para tentar receber no dia seguinte, conforme foi informado pelos técnicos.

Outra beneficiária, entrevistada no Cras Ribeirinho em Santarém, informou ter utilizado o telefone 0800 do Bolsa Família para solucionar um problema de bloqueio do benefício. Segundo ela, "eu mesma só consigo quando às vezes dá um bloqueio e eu procuro a assistência social de Brasília e eu ligo. Ligo pra ver se eu resolvo. Ás vezes custa demais, mas resolvo" (Usuária 3, de Santarém/PA).

Em Tobias Barreto, por sua vez, uma beneficiária informou que há quase três anos esperava para resolver seu problema e descobriu que "tava no cadastro da minha mãe e não me falaram e eu vim e recadastrei de novo aí veio um com o mesmo nome que eu só que com data diferente. Cadastrei de novo e vamo vê o que vai acontece dessa vez". Ela informou ainda que usa a internet para olhar sua situação no Programa Bolsa Família. Segundo ela:

[...] eu já tentei, mas a gente só pega de 2007, 2008 e agora não pega não. Inclusive eu mexi pra ver se tinha meu número, mas é cansativo, demora muito e é muito longe daqui e pra mim vim aqui todo dia ou todo mês fica muito ruim. Aí eu mexo a internet pra ver se acho, mas nunca achei não. (Usuária 7, de Tobias Barreto/SE)

Essa situação expressa pelos usuários dos Cras é a negação da democracia, da cidadania e de tudo o que preconiza a política de Assistência Social e do que se propõe 
a Comunicação Pública, no que tange ser um fluxo informativo e comunicativo em prol do fortalecimento da cidadania e da democracia. Fica explícito nas experiências desses usuários que o cidadão não é principio, meio e meta, uma vez engolido pela burocracia e pelo mau gerenciamento. Não há, do ponto de vista da Comunicação Pública, a centralidade no cidadão e o respeito à sua condição de contribuinte, eleitor e usuário, como afirmou Zémor (2005). Há uma repetição da prática que subalterniza os pobres, reeditando a condição de merecedores ou não da ajuda como se fazia à época da Lei dos Pobres, ou da meritocracia praticada pelas benesses e concessões do Estado. Sob a era constitucional dos direitos sociais, o mito fundador mantém seu vínculo interno do passado como origem, reeditando-se em novas formas de subalternizar o indivíduo.

É certo que as experiências dos usuários influem na compreensão destes a respeito dos direitos sociais, considerando-se que, em geral, eles formam suas opiniões com base no empirismo e se informam por meio da transmissão oral, denominado por eles como "boca a boca", ou seja, pela experiência de outro. Nas entrevistas junto a eles, buscou-se conhecer como percebem os direitos sociais. Como estímulo à resposta, a pergunta foi realizada da seguinte forma: quando se fala em direitos sociais o que vem à cabeça? Você sente que têm direitos? Poucos foram os que responderam, demonstrando "a herança brasileira no trato dos direitos sociais: a cidadania pelo avesso", como afirmou Silva (2012, p. 103), mas as repostas obtidas colaboraram para que se possa aprofundar sobre o que esses usuários têm apreendido sobre os direitos com a vivência nos Cras.

As respostas indicam que alguns dos beneficiários percebem os direitos sociais, vinculados ao binômio direito e dever, demonstrando que "as classes subalternas acabam por internalizar essa cultura da dominação e assumem uma posição de subordinação àquilo que lhe é imposto" (Silva, 2012, p. 96). Carregam consigo a ideia de que para receber é preciso "fazer por onde", sendo essa concepção espelho da assistência social como um valor religioso e do pensamento liberal. Como apontou Boschetti (2003), são entendimentos que atravessaram séculos e fronteiras e se reatualizam numa conjuntura neoliberal.

Outros relacionaram os direitos sociais à ideia de igualdade dos direitos. A essa compreensão houve quem vinculasse à necessidade de se ter conhecimentos para poder lutar de forma certa, porque "para se ter direito social temos que correr atrás dos direitos. Não adianta buscar o direito social se eu não sei nada sobre ele. Não sei me 
defender diante de alguém que tenha todos os conhecimentos. Temos que lutar em busca daquilo na sociedade" (Usuário 1, de Belo Horizonte/MG).

Em que pese toda uma cultura liberal do direito, há aqueles usuários da política de Assistência Social que romperam com a lógica da dominação e que compreendem o lugar que ocupam na sociedade, que é o de luta por direitos. Esses sujeitos conseguiram desenvolver uma consciência capaz de compreender que cidadania não tem relação com concessão, mas com processos históricos resultantes de lutas permanentes, travadas pelas classes e segmentos subalternizados, sendo a democracia par e passo desse processo ou, como afirmou Coutinho (2000), o melhor conceito que expressa a cidadania.

Alguns usuários vincularam os direitos sociais ao acesso a benefícios e às políticas públicas, tais como Saúde, Educação e Previdência. Acreditam que o direito social tem a ver com proteção, esta inclusive associada à velhice, à questão do racismo e à violência contra a criança e a mulher. Tem-se nessa compreensão, talvez não com um grau de profundidade, a relação entre direitos sociais e o papel da política social de assegurar proteção a segmentos da classe trabalhadora em decorrência da desigualdade social expressa nas manifestações da questão social.

Porque no nosso país a gente tem direitos que é a aposentadoria, direito de saúde, assim por diante. Não é muito fácil, mas a gente tem. (Usuária 9, de Santarém/PA)

Outras entrevistas de usuários remeteram para a questão do trabalho como algo central na vida, por ser por meio dele que as pessoas se sustentam, mantendo a si e suas famílias. No entanto, ter direitos sociais significa ter acesso quando não houver trabalho. Essa condição, por vezes constrangedora, é o que possibilita, no entendimento desses usuários, o acesso a algum nível de ajuda, como se acionar as políticas sociais fosse sinônimo de incapacidade de manter a si mesmo.

Acho que é o direito das pessoas se sentir bem pelo direito do trabalho. Quando precisar de ajuda sair e ser atendido. Direitos iguais. (Usuária 1, de São Gabriel/RS)

Nunca tive ajuda de nenhum órgão, sempre foi através do meu trabalho. (Usuária 2, de Santarém/PA)

Como apontou Boschetti (2003), a tensão entre o trabalho e a assistência social enquanto política governamental se dá desde os primórdios, uma vez que, pela lógica do primado liberal do trabalho, o homem deve manter a si e a sua família com os ganhos de 
seu trabalho, desconsiderando que o salário no capitalismo não atende às necessidades do indivíduo e que sequer existe o pleno emprego.

A partir dessas respostas e das não respostas, percebe-se que, no geral, para os usuários, a Assistência Social ainda não se configura como uma política social que visa atender as necessidades sociais dos trabalhadores, sendo um direito de cidadania. Para os que vivem oscilantes no processo produtivo, responder o que são direitos sociais torna-se mais difícil, posto que na experiência pessoal a informação de interesse privado - uma vez se tratar de informações que dizem respeito exclusivamente do cidadão - não vem acompanhada da compreensão de que o acesso se dá como direito por ser um ressarcimento decorrente do modelo econômico em vigor. Assim, o acesso ao direito ainda vem no presente com o invólucro do passado, como se fosse ajuda.

A pesquisa também procurou conhecer como os usuários compreendem o Cras e a relação deste com a política de Assistência Social e os programas de transferência de renda. Percebe-se, em geral, não haver um entendimento do Cras enquanto um equipamento do Suas que gerencia, no território, os serviços socioassistenciais e benefícios sociais do Ministério do Desenvolvimento Social e Combate aà Fome. Como abordaram alguns dos técnicos entrevistados, o Programa Bolsa Família ofusca a política de Assistência Social, dificultando as ações de acompanhamento dos usuários pelas equipes de referência, principalmente nos locais onde não é o Cras que realiza o cadastro, uma vez que, para o usuário, a referência é o lugar do cadastramento. Muitos usuários informam que estão no Cras interessados apenas no Programa Bolsa Família, não fazendo nenhuma associação com a política e nem com o Cras como uma unidade do sistema e com os serviços que ele oferece. Há outros usuários que confundem assistência social com o assistente social ${ }^{94}$ e há outros ainda que entendem a assistência social e o Cras como benefícios de transferência de renda.

O interesse da gente é só o Bolsa Família mesmo. Eu nunca ouvi dizer de outras coisas que veio resolver no Cras. Assistência Social e o Cras? Deve ter, mas ninguém nunca foi me procurar em nada não. Aqui do Cras não. Essas coisas da saúde da muiê nunca mais foram, tem muitos anos. (Usuária 7, de Tobias Barreto/SE)

Acho que não há relação entre Cras e Assistência Social porque eu estou ouvindo falar agora em Assistência Social. Assistência Social é aquela pessoa

\footnotetext{
${ }^{94}$ Assistente social é um profissional graduado em Serviço Social, que, no Brasil, é regulado como um curso de nível superior com quatro anos de duração. Ao cumprir as exigências da formação profissional, o egresso se forma como bacharel em Serviço Social. Ao requerer registro no Conselho Regional de Serviço Social na região onde reside e irá trabalhar, o profissional recém-graduado receberá o título de assistente social, sendo essa profissão regulada desde 1957.
} 
que ajuda os outros né? Vamos supor que eu precise de uma coisa que eu não tenho condições de comprar e venho aqui, converso com as pessoas e a assistente social me ajuda. (Usuária 4, de Belo Horizonte/MG)

Não há relação entre o Cras e a Assistência Social porque meu assunto aqui é só esse do Bolsa Família. (Usuária 4, de Tobias Barreto/SE)

Cras pra mim é onde você cadastra para fazer o Bolsa Família. Eu acho que é isso porque eu não recebi nada e é o que o povo fala que aqui é que faz o Bolsa Família e depois vem aqui pra renovar de novo, sei lá. (Usuária 5, de Tobias Barreto/SE)

Sobre a Assistência Social e o Cras eu vejo como um programa de incentivação e para melhorar a educação das pessoas. É um benefício que o governo paga para as famílias carentes, né? (Usuário 2, de Santarém/PA)

Outros usuários permanecem relacionando Assistência Social à ajuda, não se reconhecendo como usuários dessa política, como é o caso dos usuários que frequentam os Cras que possuem atividades de convivência para os idosos. Há ainda aqueles que confundem Assistência Social com assistência em outras áreas das políticas sociais, a exemplo da política de Saúde. Toda essa incompreensão demonstra a fragilidade da comunicação da política que, em consequência, gera uma variedade de deducionismos, como se verifica nos depoimentos abaixo.

O Cras eu entendo assim que é um lugar para as pessoas conviverem assim. Para os idosos terem um lugar e uma atividade. A Assistência Social eu acho que é mais para auxiliar as pessoas né? A pessoa chega ali e fala os seus problemas e se for mais fácil resolve na hora e se não for eles orientam. Pra mim é isso. (Usuária 2, de São Gabriel/RS)

Assistência Social pra mim, sei não. A assistência social de passar em casa não sei não pra te falar a verdade a assistência social nunca passou na minha casa [...] nessa casa só passou porque eu avisei que tava com uns problemas e eu avisei pro pessoal não sei se daqui ou do conselho, não sei, aí a assistência social não me achou em casa e disse que ia voltar e até hoje num voltou. Eu tô com um monte de exame pra fazê lá e tô apertada. (Usuária 6, de Tobias Barreto/SE)

Bom, o Cras é especial aqui pra gente. Com a assistência social eu mexi com isso de criança e é muito bom também. Advogado de graça e conversa muito bem com a gente, uma pessoa aqui também com o meu menino foi muito boa, me ajudou muito. (Usuária 5, de Belo Horizonte/MG)

Outros usuários confundem os espaços físicos ocupados pelos equipamentos com a política, como foi em Tobias Barreto/SE em que a secretaria de Assistência Social funciona próxima ao Cras que atende a população rural. Em uma entrevista, o usuário disse: "Assistência Social é mais devagar, porque demora muito pra ser atendida" (Usuário 1, de Tobias Barreto/SE), referindo-se ao equipamento destinado à gestão, e não à política pública. 
O conselheiro representante dos usuários no CMAS de Belo Horizonte acredita que as pessoas não se importam muito com a Assistência Social porque estão mais preocupadas com a saúde, a educação e em ganhar dinheiro. Segundo ele, se "você fala educação o pessoal fala: opa! Quando é assistente social, ${ }^{95}$ eles falam: pode deixar pra depois. Não é necessidade. Num âmbito geral a assistente social não tem importância nenhuma porque ainda é um circulo muito fechado".

Na perspectiva da comunicação, o que se percebe é que o impacto da ausência da comunicação de governo sobre o usuário faz com que alguns deles não a percebam como uma política pública, sendo que para outros ela sequer existe. Ou seja, não havendo uma comunicação massiva por parte do setor de comunicação de governo, a busca por legitimação da gestão estatal, conforme definição de Matos e Gil (2013), não ocorre, dando a impressão inclusive de se tratar do comportamento dos membros de gestão, atribuídos como um "círculo muito fechado". Não havendo publicidade, não há transparência e nem prestação de contas. Portanto, falta à Assistência Social a atitude de Estado que funciona como um elemento estratégico de mediação entre os sujeitos sociais e o governo. Essa contribuição de governo poderia, de acordo com Brandão (2009), desencadear-se por meio de ações voltadas para a cidadania e sem ser por meio do embate argumentativo. Uma ação adequada seria prestar contas à sociedade a respeito do investimento realizado em Assistência Social e o que isso representa em uma sociedade desigual como é a brasileira.

Por meio das entrevistas junto aos usuários, procurou-se conhecer a relação deles com as novas tecnologias, como, por exemplo, o uso do celular. Apurou-se que a maioria dos usuários entrevistados possui telefone celular e não consideram que troquem tanto o número, sendo que a metade se comunica por meio de mensagens mesmo quando tem pouca leitura ou enxergam com dificuldade, contando com o auxílio dos filhos e dos netos. Alguns usuários mais idosos informam ter celular, mas possuem pouca paciência para operá-lo. Muitos recebem de presente o aparelho dos filhos como uma forma inclusive de monitorá-los. Decorrente do pouco interesse, alguns deles não memorizam o número do telefone, como nos informa uma usuária entrevistada em Belo Horizonte.

Tenho celular há pouco tempo. Eu quase não uso meu celular, eu não tenho paciência. Minha neta e meus netos é que sempre ficam vendo as mensagens

\footnotetext{
${ }^{95}$ Considera-se que o conselheiro, nesse caso, está se referindo à política de Assistência Social, e não ao profissional assistente social.
} 
nos telefones deles, mas o meu mesmo fica lá em cima da mesa. Vou fazer comida e deixo em cima da geladeira ou cai e minha neta informa que tá embaixo da cama. Eles me dão de presente. Aonde eu vou levo ele, mas ninguém liga pra mim. Ontem minha cunhada foi lá em casa e eu ia dar o meu número de celular e eu não sabia. Meu filho me passou o número e ainda não gravei. (Usuária 4, de Belo Horizonte/MG)

Desses usuários que indicaram ter celular, muitos possuem internet no próprio aparelho e alguns utilizam o programa de troca de mensagens WhatsApp. Esses usuários são mais jovens e tem filhos. Alguns indicaram que o uso do celular está condicionado a ter crédito e ao sinal, sendo que alguns só conseguem operar quando saem de sua comunidade. Há, inclusive, em algumas localidades, a transformação do aparelho celular em telefone fixo, pois o ligam em uma antena para captar o sinal. Dessa forma, o aparelho só pode ser usado naquele local. Quando questionados sobre ter computador em casa, poucos usuários informaram possuí-los, sendo um grupo bem reduzido o dos usuários entrevistados que utilizam. Dentre os que utilizam computador, alguns frequentam lan house ou a biblioteca da escola local.

A rede social Facebook é a campeã entre os que utilizam a internet, seguido pelo uso da internet para realização de pesquisas para os filhos. Há aqueles que têm e-mails, mas a maioria dos que usam a internet não tem. No geral, usam pouco. Porém, o Facebook é frequente e serve para aproximar dos amigos e da família quando distantes. Houve o caso de duas senhoras idosas, em São Gabriel/RS, que usam o programa de telechamadas Skype por causa de filhos que moram em outras localidades. Perguntou-se para os que utilizam o Facebook se conheciam as páginas do Ministério do Desenvolvimento Social e do Programa Bolsa Família nessa rede social, mas apenas uma pessoa em Tobias Barreto informou conhecer.

A experiência dos usuários com as novas tecnologias atesta o que muitos autores já explicitaram acerca desse período, sendo que, para Del Bianco (2005), a revolução tecnológica tem alterado a experiência de mundo assim como a revolução industrial modificou as relações técnicas de produção e as relações sociais à época. Sem dúvida, é esse o perfil daqueles quase um milhão de beneficiários do Programa Bolsa Família que se lançaram em um fim de semana nas ruas de 13 estados do país e que não identificaram nos Cras a possibilidade de esclarecer os fatos, uma vez que nem sempre essas unidades são referências para o cadastramento no Programa Bolsa Família e também porque $89,1 \%$ dos Cras funcionam entre 40 a 49 horas por semana, sendo provavelmente essa jornada cumprida nos dias úteis, e não aos finais de semana, como ocorreu com o episódio denominado como "boato do fim do Bolsa Família". Além 
disso, como o Programa Bolsa Família não consegue ter uma vinculação direta com a Assistência Social, para a opinião pública e para os beneficiários o que prevalece são as relações burocráticas e bancárias, no caso, representada pela Caixa Econômica Federal e pelas Casas Lotéricas.

No geral, os usuários indicaram que é por meio do rádio que eles obtêm as informações mais gerais e também sobre suas questões específicas, mas, para uma comunicação mais ágil com os usuários, consideram que a melhor forma de acessá-los é por ligação para telefone celular; boca a boca, que pode ser por meio de visita domiciliar; recado com o vizinho; aviso na Igreja; envio de carta; por meio de um telefone fixo ou rural; e por mensagem de celular. Eles indicam que os folhetos ajudam a esclarecer situações, como, por exemplo, problemas na escola, ofertas de trabalhos, lista de documentos para cadastro em programas, entre outros. Além disso, consideram que a TV seria um bom meio para divulgar os serviços do Cras, assim como a Comunicação Pública, como indicou uma usuária em Santarém/PA: "uma Comunicação Pública, um jornal, televisão".

O conselheiro representante dos usuários no CMAS de Belo Horizonte, por sua vez, considera que as melhores formas de comunicar com o usuário "tem que acompanhar a moda, né? Antigamente eram os impressos e hoje tem que ser algo bem mais rápido. Hoje as pessoas não tem tempo de ficar lendo.” No entanto, observa que os computadores da prefeitura são um antigos e, em alguns lugares, lentos, dificultando o trabalho. Considera também que a mensagem por meio do celular é uma boa ideia, mas não atinge a maioria das pessoas. Além disso, acredita que a mensagem funcionaria para os usuários da Assistência Social porque a política não possui Facebook.

De acordo com Kats (et al., 2005), a tecnologia é modelada por necessidades individuais e contextos sociais. Por meio de pesquisa, os autores relatam experiências positivas em que vários países (China, EUA, Ruanda, Quênia, entre outros) adotaram o uso de mensagens curtas, por meio do telefone móvel, para orientar a população, principalmente a de baixa renda, no combate e no enfrentamento de doenças como SARS, malária, HIV, entre outros serviços de saúde. A pesquisa realizada por Rego e Pinzani (2013, p. 141) junto às beneficiárias do Programa Bolsa Família, no período de 2006 a 2011, no interior do sertão brasileiro e no Vale do Jequitinhonha, indicou que algumas beneficiárias já “estão podendo comprar à prestação até telefones celulares", acompanhando a tendência mundial das novas formas de comunicação sem fio, a 
exemplo do telefone móvel, que oferece a possibilidade de mensagens curtas, fazendo aumentar substancialmente a sociabilidade.

A questão apontada pelo conselheiro em relação à linguagem, quanto a ser rápida em detrimento do pouco tempo disponível das pessoas, confirma a análise de Ramonet (2009), que afirma que o discurso atual, aos poucos naturalizado pela sociedade, caracteriza-se por ser um discurso rápido, com vistas a evitar o tédio, sendo tudo feito a partir de um modelo publicitário que utiliza artigos curtos, frases breves e títulos impactantes e com elementos de espetacularização ou de dramatização, para que se provoquem emoções.

Assim, aos poucos os usuários da Assistência Social vão se aproximando da sociedade midiatizada e, ainda que estejam formados culturalmente pela sociedade dos meios de comunicação de massas ou pela indústria cultural, já começam a experimentar processos comunicativos que ganharam velocidade e espaço com a presença de participantes sociais nas práticas e nos processos antes restritos à indústria cultural, como afirma Braga (2012). Assim, o receptor, considerado em outros tempos como passivo e acrítico, não só quebrou a lógica da fidelização, mas ainda faz seguir adiante as reações ao que recebe. Nessa perspectiva, a inserção cultural do receptor é compreendida como uma mediação fundamental entre a sociedade e as proposições da mídia de massa e se põe, historicamente, como um espaço da ação de resistência política e social. 


\section{CONSIDERAÇÕES FINAIS}

Este estudo sobre a Comunicação Pública junto aos usuários da política de Assistência Social evidenciou muitas questões, e a melhor delas é saber que "toda formação social é suficientemente contraditória, para ser historicamente superável" (Demo, 1995, p. 89), sendo essa a própria história da Assistência Social e também da Comunicação Pública no Brasil.

O conhecimento sobre a realidade da Comunicação Pública junto aos usuários dos Cras denuncia que, embora o Suas seja a materialização de uma luta histórica dos movimentos sociais pela assistência social em se transformar em uma política pública, sua implantação, tendo o neoliberalismo à brasileira como o fio condutor que não cessa de reeditar o clientelismo e a subalternidade, exige daqueles que constituem as forças em presença e que lutam pelos direitos humanos e sociais muita persistência, criatividade e, contraditoriamente, abnegação, voluntarismo e messianismo. Assim é a história dos homens, construída entre contradições e mediações, sendo a antítese a alma da dialética, uma vez que toda realidade social gera, por meio da dinâmica interna própria, o seu contrário. Desse modo tem sido a construção da democracia e das políticas públicas neste país. E em que pese o capitalismo nesse estágio desmontar os direitos trabalhistas, recuar nos direitos sociais, retroceder a democracia e expor como nunca o meio ambiente planetário a uma devastação sem precedentes, isso não significa o fim da história, mesmo com todo o poder da alienação histórica, capaz de fazer atravessar séculos e fronteiras concepções ideológicas opressoras, preconceituosas e segregadoras. Afinal, é por meio da práxis que se vinculam as condições objetivas e subjetivas para a superação e desenvolvimento do ser social.

A dinâmica societária se realiza com base em muitas totalidades e não se pode determinar que o fator econômico seja o único a promover as mudanças societárias, haja vista que os fatores sociais e culturais também são determinantes para a transformação da realidade social. Em cada totalidade da Assistência Social analisada observam-se focos de resistências quanto ao aprofundamento da democracia, ao acesso aos direitos humanos e sociais, o respeito ao trabalhador e ao exercício da cidadania, mesmo que isso ocorra em processos comunicativos em que o universo da Comunicação Pública seja desconhecido, o que não significa a ausência de um campo fértil para a sua realização. Afinal, as mesmas forças que asseguraram um compêndio de normativas e 
de orientações se espraiam anonimamente no cotidiano brasileiro, apesar das forças conservadoras.

Uma questão evidenciada nesta tese diz respeito à relação entre Comunicação de Governo e a Comunicação Pública, no sentido de que são complementares quando a Comunicação de Governo colabora na organização e na publicidade da política em geral. Pelas informações organizadas ao longo deste estudo, um dos grandes prejuízos para a Comunicação Pública junto ao usuário no cotidiano - para o debate público em relação ao objeto da política e suas especificidades, bem como para a superação do clientelismo/mito fundador - está no fato de inexistir uma política de comunicação de governo para a área, considerando-se ser uma de suas funções "a busca de legitimação da gestão estatal”, como afirmou Matos e Gil (2013, p. 100).

O fato de a Assistência Social não ser noticiada pelo governo nos meios de comunicação de massa como são outras áreas - e, inclusive, ser sombreada pelo Programa Bolsa Família como se não houvesse nenhuma relação - não colabora para o trabalho cotidiano, como apontou o conselheiro de Belo Horizonte, usuários e as equipes técnicas de referência. Ou seja, além de não prestar contas de seus feitos, o governo compromete o desempenho dos serviços, negligencia o direito à comunicação e, consequentemente, não fortalece a democracia, o exercício de cidadania e nem colabora para o rompimento com a cultura da subalternidade. Daí que não se podem criticar os usuários por não verem nenhuma relação entre a Assistência Social, o Cras e o Programa Bolsa Família.

Tem-se a impressão de que, para o núcleo duro do governo federal, a não publicidade da Assistência Social decorre da falta de reconhecimento de sua importância enquanto uma política estratégica para os trabalhadores. Ou ainda que, sob a pressão e diversidade da demanda da Assistência Social, visto que seu universo são as expressões da questão social, o governo termina apostando na publicização da transferência de renda por expressar uma síntese desse amplo universo, além de, ao satisfazer o mercado, tornar mais palatável aos olhos da sociedade a assistência aos pobres, apesar da mesquinharia de alguns setores da classe dominante, que detêm parte expressiva da mídia, que, por sua vez, alimenta permanentemente a opinião pública com a ideia do comodismo, do "ensinar o homem a pescar" e outras máximas ignorâncias totalmente descompromissadas com os interesses dos trabalhadores.

É certo que a compreensão da Comunicação Pública como um direito transversal às políticas sociais é algo muito recente, ainda com poucos estudos. No entanto, o 
direito à comunicação é tão antigo quanto as lutas por democracia e por cidadania. É compreensível que na primeira e na segunda fase de implantação do Suas essa questão ficasse relegada, em que pese as normativas apontarem na direção do direito à informação e à formação cidadã. É de se estranhar, no entanto, a comunicação não entrar na fase denominada de "qualificar o sistema". A respeito disso, importa destacar o pouco acúmulo quanto às ações comunicativas organizadas na área e o despreparo dos profissionais de comunicação no trato com o tema e, em consequência, com as pessoas que o circundam, como foi mencionado nas entrevistas tanto no âmbito nacional quanto municipal. Há de se refletir e buscar respostas para compreender essa lacuna, uma vez que a Comunicação Pública é uma unidade dialética entre a dimensão humana e técnica da comunicação, conforme indicou Gomes (2007). Portanto, necessita também da presença dos profissionais que detêm suas técnicas, seja no nível nacional como também nos munícipios, com a função de atender a Proteção Social Básica. Em meio a tantas categorias profissionais que disputam serem reconhecidas como necessárias ao Suas, quais são os motivos que mantêm afastados os profissionais de comunicação desse debate político, dessa busca por mercado de trabalho?

Outra evidência percebida é que a Comunicação Pública não tem sido priorizada pelas gestões municipais e estaduais, em que pese, em alguns munícipios, o controle social indicar a necessidade, reproduzindo, nessas esferas de governo, a mesma condução que o governo federal dá a comunicação para a área. Essa ausência ocorre por motivações diversas, podendo-se afirmar que algumas se dão por influência do primado liberal, que, às vezes, vem acompanhado, inclusive, de valores religiosos. Para muitos destes, o Estado não tem a tarefa de trabalhar com a informação voltada para a cidadania (Matos, 2009; Brandão, 2009), sendo asseguradas apenas as estruturas exigidas pelo MDS para que o repasse de recursos financeiros não fique comprometido. Optam, portanto, pelos rendimentos que o clientelismo pode oferecer em suas várias modalidades. Por isso não se preocupam com os baixos investimentos de infraestrutura ou na produção de instrumentos na justa medida para a compreensão do cidadão, uma vez que a Assistência Social enquanto política pública é invisível. Apostam no voluntarismo como alternativa às precárias condições de trabalho, no compromisso técnico-ético-político dos profissionais, que, por sua vez, disponibilizam celulares, carros e energia sem remuneração. Não se importam que a política fique à deriva da boa vontade de terceiros, de arranjos comunitários, da polivalência dos técnicos que se disponibilizam, como, por exemplo, designers gráficos, fotógrafos, jornalistas, atores, 
dançarinos, relações públicas, etc., contanto que entrem nas estatísticas positivas rendendo-lhes retornos financeiros e políticos e que tenham eventos para irem, serem vistos discursando para povo e tenham imagens para a imprensa.

Essa situação evidencia a subalternização da própria política, sendo que esta se reproduz na condição de muitos gestores municipais na relação com os prefeitos e com os trabalhadores, como corroborou Silva (2014). São colocados nessa condição também em decorrência do baixo investimento financeiro destinado aos serviços socioassistenciais. Entretanto, é preciso ser cauteloso em relação à questão dos recursos financeiros, uma vez que a diferença é muito significativa entre o que foi e o que é. Torna-se necessário, também, atentar-se para a transferência de responsabilidades para os municípios, uma vez que muito se imputa, mas pouco se remunera, principalmente em modelos de gestão descentralizada. Porém, o que se observa em geral na Assistência Social é que o governo federal tem assumido responsabilidades em conjunto com os municípios, sendo que alguns deles fazem menos do que poderiam fazer tendo em conta as possibilidades de sua arrecadação, considerando-se que, no geral, os governos de estados são omissos ou pouco participativos. Essa prática política que subalterniza a política e tudo o que a envolve o faz por compromisso com o conservadorismo e para reeditar o mito fundador que se exprime sempre de forma que pareça se tratar de uma novidade, e não de uma repetição de si mesmo. Com esses liberais convictos, a margem de negociação deve ser muito pequena, sendo necessária muita austeridade na fiscalização e, também, monitoramento da política pública.

Se, por um lado, esse conservadorismo é expressão de uma ideologia, estando no campo da política seu enfretamento e na gestão o controle da qualidade dos serviços ofertados, por outro lado, a reprodução pode ser fruto da ignorância, principalmente quando está associada aos técnicos, por mais contraditório que isso pareça. Todavia, ao considerarmos a precarização da formação profissional, sendo o ensino a distância a expressão maior da mercadologização da formação em Serviço Social nos últimos anos, não é de se estranhar, por parte desses profissionais, a reedição do passado e a confusão entre conceitos tão elementares como direitos sociais e privilégio, entre outras práticas que reproduzem e reforçam a exclusão e que não apontam para a superação e protagonismo dos subalternos. Afinal, quem são os mais de 250 mil trabalhadores que operam a Assistência Social no Brasil? Alguns assistentes sociais com os quais tivemos contato em conversas informais nas visitas realizadas omitiram a instituição de sua formação e alguns nos confidenciaram suas inseguranças profissionais em decorrência 
da formação precarizada resultante, na maioria, pelo ensino a distância. O que se sabe é que esses trabalhadores também estão submetidos às mesmas regras do capital e buscam, por meio da formação uma ascensão profissional, uma vida melhor. Se o mercado oferece uma formação profissional em nível superior sob a chancela das facilidades advindas das novas tecnologias e da sociedade midiatizada, com a aquiescência do governo, não há porque um trabalhador resistir.

O mesmo governo que, em obediência ao mercado, permite a oferta de um ensino superior precarizado aos trabalhadores, acessível a eles devido ao baixo valor das mensalidades (e a consequente precarização dos professores universitários), é também aquele que não enfrenta o debate para a democratização da comunicação, permitindo que a mídia funcione como um partido, sem o ônus dele, como afirmou a assessora de comunicação do MDS, Adriana Moraes. Sendo assim, é preciso destacar o preço que a sociedade brasileira tem pagado desde a era FHC, decorrente da possibilidade de reeleição para mais um mandato no executivo, considerando-se o clientelismo partidário. Como afirmou Martin-Barbero (2013), os partidos se ocupam apenas de se sustentarem no poder, e, em se tratando da hegemonia neoliberal, assegura-se os interesses do capital em detrimento do interesse geral. No Brasil, já se vão duas décadas de neoliberalismo e até o momento avançou-se pouco em relação à democratização da comunicação.

Com base nas considerações expostas acima, é praticamente uma ingenuidade restringir o CapacitaSuas ao conteúdo restrito das normativas da política. É preciso reconhecer que a execução da política está comprometida quando, por mais improvável que pareça, um técnico de nível superior não consegue distinguir que a abordagem de um agente público da saúde é diferente da abordagem com bases religiosas sobre sexualidade e saúde da mulher. É preciso que o CapacitaSuas seja um canal de interlocução com o técnico e que possibilite a esse trabalhador perceber o contexto de sua ação profissional, a escolher melhor as ferramentas de trabalho.

Esta tese evidencia ainda que a ausência da Comunicação Pública nos Cras esvazia o potencial do Suas, que, de acordo com Silva (2014), tem a atribuição de levar os usuários à participação ativa da vida política, contribuindo assim para a manutenção e para a ampliação de direitos para as classes subalternas, e, consequentemente, contribuindo para a ampliação e a consolidação da democracia na sociedade brasileira.

Com a Resolução do CNAS $n^{\circ} 11$, de 23 de setembro de 2015, além da caracterização dos usuários, definiram-se também os seus direitos e participação na 
política de Assistência Social e no Sistema Único de Assistência Social. A Resolução informa que serão considerados representantes de usuários somente os sujeitos coletivos vinculados a serviços, programas, projetos, benefícios e transferência de renda da política de assistência social, devendo se mobilizarem sob diversas formas, tais como: associações, movimentos sociais, fóruns, conselhos locais de usuários, redes ou outras denominações, desde que tenham entre os seus objetivos a defesa e a garantia de indivíduos e coletivos de usuários do Suas. A partir dessa Resolução, gestores públicos estatais ou das entidades ou organizações de assistência social e trabalhadores do Suas não representam mais os usuários nas instâncias deliberativas do Suas - nos conselhos e nas conferências de Assistência Social -, devendo os conselhos de Assistência Social efetivarem programas de formação para usuários e lideranças comunitárias. Com essa Resolução estão reafirmados os apontamentos para que, de acordo com o segundo parágrafo do artigo $4^{\circ}$, seja assegurado ao usuário "o direito de ter acesso a informações e orientações relativas aos serviços, programas, projetos, benefícios e transferência de renda no âmbito da Política Pública de Assistência Social, em linguagem clara, simples e acessível" com vistas ao protagonismo político e social do usuário.

Outra evidência proporcionada pelo estudo desenvolvido diz respeito à proximidade entre os tipos de mensagem da Comunicação Pública, proposto por Duarte (2009), e o que vem sendo desenvolvido na Assistência Social, em que pese a ausência de reflexão a respeito do direito à comunicação, resistências e até oposição na própria política, o que faz gerar muita precariedade, comprometendo o desenvolvimento da Comunicação Pública. No entanto, é possível perceber um potencial, considerando-se que o que é praticado pode ser melhorado ou superado, no caso de haver vontade política inclusive para o enfrentamento das práticas conservadoras.

Ao abordar o tipo de mensagem institucional verifica-se que há o contato direto entre usuário e equipe de referência no cotidiano, a existência de materiais impressos informativos e a utilização de redes sociais (Facebook), estando os equipamentos próximos aos usuários e estes, por sua vez, satisfeitos com o atendimento das equipes de referência do Cras. No entanto, o material é produzido pelos próprios técnicos, o que dificulta a produção de instrumentos na justa medida, acarretando problemas na comunicação e a necessidade de esclarecimentos a respeito das especificidades da política, tendo como consequência o não reconhecimento por parte dos usuários e da sociedade em geral. 
Em relação ao tipo de mensagem que diz respeito às informações de gestão, o que se percebe é que com o advento do Suas há uma maior circulação interna das informações, deliberações, normativas e capacitações, por meio de materiais impressos e de tecnologias ligadas à internet. Porém, há uma dificuldade por parte dos agentes gestores dirigentes em assegurar a comunicação enquanto uma política de gestão, não afirmando, portanto, a Assistência Social como política pública. Não há estratégias de comunicação de massa e tampouco com a mídia comercial, acarretando, assim, em muitas incompreensões por parte do público usuário e a quase invisibilidade da área como política pública. Assim, conceitos básicos como Assistência Social, assistente social, Serviço Social, acompanhamento familiar, entre outros, são sempre confundidos.

As informações do tipo de utilidade pública dizem respeito às informações que estão relacionadas ao dia a dia das pessoas, portanto, estão ligadas à Assistência Social, à rotina dos Cras, aos atendimentos individuais e às reuniões coletivas realizadas com fins educativos. Percebe-se que há uma comunicação direta por meio da escuta e do diálogo entre a equipe de referência e os usuários, seja individualmente, coletivamente ou comunitariamente, sendo que a proximidade do local de moradia favorece a uma maior compreensão a respeito da cultura dessas pessoas. Contudo, falta uma melhor identificação do técnico, afinal, apenas a utilização de uniformes não assegura transparência. Constatou-se a necessidade de um suporte de comunicação adequado, por parte das prefeituras, às atividades internas e externas na comunidade. Além disso, em alguns Cras visitados, a forma de garantir a participação dos usuários pelos técnicos reproduz relações autoritárias, paternalistas e tuteladas, que reforçam a subalternidade, de partida negligenciando as normativas e as suas finalidades, o que, do ponto de vista da Comunicação Pública, é irreparável, considerando-se o seu compromisso com a democracia e o atendimento ao cidadão como meio e meta de todo o trabalho.

A Prestação de Contas é um tipo de informação que prevê a apresentação e esclarecimentos sobre as decisões políticas e sobre o uso de recursos públicos, inclusive de ordem orçamentária e financeira. Como vimos anteriormente, a Assistência Social possui uma gestão compartilhada entre os entes federados e conta com controle social. De dois em dois anos são realizadas as conferências nacional, estaduais e municipais, para a avaliação e a deliberação de diretrizes para a política. Em todo o país estão em funcionamento os Conselhos de Assistência Social no âmbito nacional, estaduais e municipais, e os repasses financeiros ocorrem somente por meio dos Fundos de Assistência Social (nacional, estadual e municipal) sob o monitoramento do controle 
social. Permanece, no entanto, a questão do baixo percentual aplicado nos serviços continuados da Assistência Social. Além disso, a prestação de contas é limitada aos operadores do sistema, haja vista a ausência de uma comunicação de massa.

Já as informações do tipo de interesse privado são aquelas que dizem respeito exclusivamente ao cidadão ou às instituições privadas. Trata-se dos serviços prestados no Suas e, especificamente, nos Cras em relação ao acompanhamento às famílias inseridas nos serviços e nos benefícios sociais. Percebe-se um compromisso e um esforço da equipe técnica em viabilizar o direito do cidadão, havendo uma variedade de canais para comunicação direta, sendo que os usuários, em geral, têm acesso às novas tecnologias de comunicação. No entanto, a infraestrutura é precária, o que acarreta, muitas vezes, em negligência e em desrespeito com o usuário, como ocorre principalmente em relação ao Programa Bolsa Família.

A informação do tipo mercadológico refere-se à divulgação de produtos e serviços que participam de concorrências no mercado. Na Assistência Social seria uma divulgação ao contrário, não de produtos para concorrer no mercado, mas de captação de quem presta serviços socioassistenciais no mercado, uma vez que parte dos serviços da política são ofertados por meio de parceria entre o Estado e entidades da sociedade civil, sendo repassados recursos financeiros públicos para a prestação de serviços assistenciais. Desde a era Vargas, a relação com as entidades filantrópicas sempre foi decidida pelo próprio Presidente da República, seguido pelo Congresso Nacional e, posteriormente, pelo Conselho Nacional de Serviço Social (CNSS), cuja composição envolvia políticos e pessoas da elite, que fornecia o título de filantropia com vistas à isenção de impostos. Ao longo da história ocorreram muitas denúncias envolvendo algumas dessas entidades, o que suscitou, após a Constituição de 1988, o debate sobre o papel do Conselho Nacional de Assistência Social em relação ao registro das entidades e de concessão de Certificado de Entidade Beneficente de Assistência Social (Ceas). Em novembro de 2005, foi aprovada uma Resolução pelo Conselho Nacional de Assistência Social (CNAS) que definiu sobre as características essenciais para o reconhecimento e para o registro de entidades de Assistência Social nos conselhos de Assistência Social. A partir dessa Resolução não se caracterizam como entidades e organizações de assistência social as entidades religiosas, os templos, os clubes esportivos, os partidos políticos, os grêmios estudantis, os sindicatos e as associações que visem somente ao benefício de seus associados, que dirigem suas atividades a público restrito, categoria ou classe. Em que pese a seleção da rede filantrópica, isso não quer dizer que a 
concepção majoritária entre esses prestadores de serviços socioassistenciais seja a da assistência social como um direito à proteção social, haja vista o perfil religioso e político de muitas dessas entidades.

Quanto ao tipo de mensagem que disponibilizam os dados públicos, isto é, os dados produzidos pelo Estado que dizem respeito à coletividade, como, por exemplo, as leis, as normas, os estudos e as estatísticas, na Assistência Social todas as leis e normativas são disponibilizadas em versões impressas e no site do MDS. Em todos os eventos da área sempre há um estande do ministério para distribuição gratuita desses materiais.

Outra ferramenta criada em 2007, é o Censo Suas, regulamentado pelo Decreto 7.334/2010. Trata-se de um processo de monitoramento que coleta dados por meio de um formulário eletrônico preenchido pelas secretarias e pelos conselhos de Assistência Social anualmente, no decorrer do segundo semestre de cada ano. O Censo Suas tem se consolidado como um dos principais instrumentos para o planejamento e para o monitoramento da Assistência Social ao produzir informações que permitem o acompanhamento das unidades gestoras e prestadoras de serviços do Suas, bem como do controle social, estando disponível no site do MDS para acesso da sociedade em geral.

Esses materiais, porém, só existem em versões para gestores e técnicos. Somente em 2005 e em 2006 foi distribuída pelo MDS uma revista com uma história em quadrinhos que informava sobre o Suas, a sua organização e a sua estrutura, bem como sobre o controle social. Foram distribuídos 80.000 exemplares, porém, essa publicação não está disponível no site do MDS.

Quanto às formas da Comunicação Pública apontadas por Zémor (2009), na Assistência Social podemos considerar que, em relação à estrutura de organização, de armazenagem e de socialização da informação, houve algumas alterações, como, por exemplo, a recente reformulação do site do MDS, melhorando a organização, o que otimiza as buscas e o acesso às informações. No site, há um investimento também em relação à acessibilidade. Além disso, o Censo Suas tem se configurado como uma ferramenta de planejamento e já foi premiado no $16^{\circ}$ Concurso Inovação na Gestão Pública Federal, em 2011. Contudo, o acesso dos usuários aos dados continua sem investimento, não havendo canais com linguagem acessível e nem o incentivo ao acesso para aqueles que já usam a internet. 
Em relação à recepção, podemos concluir que os Cras adotaram a identificação indicada pelo MDS e os imóveis próprios propiciam uma recepção próxima ao entendimento da recepção da Comunicação Pública. Porém, a presença de equipamentos multimídia nos Cras não quer dizer que haja oferta de informações numa linguagem ajustada ao público usuário e nem tampouco os assuntos disponibilizados na TV aberta são compatíveis com uma cultura emancipadora. Além disso, nenhum técnico estava identificado com nome e função, embora estejam uniformizados na maioria dos lugares.

Quanto à escuta e ao diálogo, eles compõem o cotidiano dos Cras e são o principal instrumento de trabalho junto aos usuários. Percebe-se que ambos requerem tempo e capacidade de mediação do técnico em relação ao usuário. Essas duas ações são apontadas pelos trabalhadores como um grande desafio, considerando-se que, de acordo com os técnicos, o tempo requerido é incompatível com o desempenho de outras muitas atividades e, em relação à linguagem, é comum os comentários sobre a necessidade de qualificação e de revisão, uma vez que a linguagem oral utilizada precisa ser uma linguagem ajustada ao perfil do usuário, e o conteúdo compatível com uma abordagem emancipadora.

Sobre as Campanhas de informação de interesse geral, há uma adesão nacional à duas campanhas ${ }^{96}$ cujos indicadores sociais no país são relevantes e que ocorrem principalmente porque o governo federal assegura recursos financeiros para a realização delas. Percebe-se o empenho das equipes de referência dos Cras para a realização de tais campanhas em articulação com a rede. No entanto, além de os recursos financeiros serem parcos, não há um apoio de profissionais de comunicação para a produção de materiais para visibilidade do evento. Muitas vezes, são reproduzidos os nomes das campanhas sem nenhum ajuste, o que produz faixas longas e inadequadas inclusive às ruas estreitas da maioria das cidades, que, por sua vez, são de pequeno porte.

A respeito da comunicação interna, da publicidade dos serviços e da valorização da política institucional, o que se percebe em relação à comunicação interna é que ocorreram mudanças significativas, mas, em relação à comunicação externa, seja para o público atendido ou para a sociedade em geral, ou ainda para as políticas sociais setoriais, parceiros da rede privada e a mídia, entre outros, a ausência de investimentos é total, o que compromete não só a legitimidade e desenvolvimento da política, mas também a própria democracia.

\footnotetext{
${ }^{96}$ Trata-se das campanhas de combate a exploração sexual de crianças e adolescentes, bem como a de combate ao trabalho infantil.
} 
Reconhecer a comunicação como um direito humano integrado ao direito e à política de Assistência Social é reconhecê-la como uma política cuja informação é de interesse geral, sendo o cidadão a principal motivação. É assumir que essa política tem um compromisso estratégico com os segmentos mais estigmatizados da classe trabalhadora e, portanto, requer uma comunicação cujo processo seja maior que informar, tornando-se necessário que os instrumentos sejam criados na justa medida. É preciso, por fim, dotar de mais recursos financeiros para que a comunicação, entendida como um todo, invista em infraestrutura, logística, em condições de trabalho, em melhores salários, na contratação de técnicos especializados em comunicação e publicize que, embora os tempos sejam de recrudescimento do liberalismo, a Assistência Social enquanto política pública é mais que uma simples ajuda, sendo por isso que se luta por ela. Como disse o conselheiro em Belo Horizonte: "a Assistência Social tem um diferencial que é o de que ela fala com o coração. A gente vai aprendendo, né?"

Ao longo da pesquisa, percebeu-se que há várias formas e possibilidades de comunicação com os usuários de modo a qualificar seu entendimento sobre a política de Assistência Social e o cotidiano, estimulando o protagonismo e a cidadania. A era digital, inclusive, amplia as possibilidades dessa interlocução, pois tornou possível a mescla do texto, do som e da imagem, não estando os usuários tão distantes assim do acesso a essas tecnologias.

Percebeu-se ainda que as questões apresentadas inicialmente e que foram a motivação de toda a pesquisa revelaram um universo muito mais amplo e complexo que apontam para muitas compatibilidades entre a Comunicação Pública e a Assistência Social, em que pese as contradições.

Sem dúvida, há um caminho ainda a ser percorrido na Assistência Social em relação à produção de instrumentos na justa medida para a comunicação com o usuário - e que esteja articulada aos tipos, formas e à singularidade da Comunicação Pública. Como bem disse o escritor Saramago: "não tenhamos pressa, mas não percamos tempo". 


\section{REFERÊNCIAS}

ADORNO, Theodor; HORKHEIMER, Max. A indústria cultural: o esclarecimento como mistificação das massas. Dialética do esclarecimento: fragmentos filosóficos. Rio de Janeiro: Jorge Zahar, 1985.

AFONSO, L. Pesquisa Qualitativa sobre metodologias de Trabalho Social com Famílias no âmbito do PAIF. Serviços de Consultoria no âmbito do Programa PNUD BRA/04/046.

ANTUNES, Ricardo. Os sentidos do trabalho: ensaio sobre a afirmação e a negação do trabalho. São Paulo: Boitempo, 1999.

BARBOSA, LÍVIA. O Jeitinho brasileiro: a arte de ser mais igual do que os outros. Rio de Janeiro: Elsevier, 2006.

BEHRING, Elaine Rossetti. Principais abordagens teóricas da política social e da cidadania. Cadernos de Capacitação em Serviço Social e Política Social. Módulo 3. Brasília: UnB, 2000.

Política Social no Capitalismo Tardio. São Paulo: Cortez, 1998.

Brasil em Contra-Reforma, desestruturação do Estado e perda de direitos.

São Paulo: Cortez, 2003.

; SANTOS, Silvana Mara Morais dos. Questão social e direitos. In:

CFESS/ABEPSS. Serviço Social: direitos sociais e competências profissionais. Brasília, 2009.

; BOSCHETTI, Ivanete. Política Social: fundamentos e história. Biblioteca

Básica. Volume 2. São Paulo: Cortez, 2006.

BOSCHETTI, Ivanete. Assistência Social no Brasil: um direito entre a originalidade e conservadorismo; $2^{\mathrm{a}}$ edição. Brasília, 2003.

BENJAMIM, Walter. A obra de arte na era de sua reprodutibilidade técnica. Magia e técnica, arte e política. Ensaios sobre literatura e história da cultura. Obras escolhidas volume 1. São Paulo: Editora Brasiliense.

BEZZON, Lara Andréa Crivelaro. "Análise político-sociológica do reencontro da sociedade civil brasileira com a cidadania e a democracia segundo a perspectiva da comunicação pública". In: OLIVEIRA, Maria José da Costa. Comunicação Pública. Campinas: Alínea, 2004.

BIANCO, Nelia R. Noticiabilidade no rádio em tempos de Internet. Disponível em: <http://www.bocc.ubi.pt/pag/bianco-nelia-noticiabilidade-radio-temposinternet.pdf $>$. Acesso em: 27 jan. 2016.

E tudo vai mudar quando a digital chegar. Disponível em:

<http://www.bocc.ubi.pt/pag/bianco-nelia-radio-digital.pdf>. Acesso em: 18 jul. 2012. 


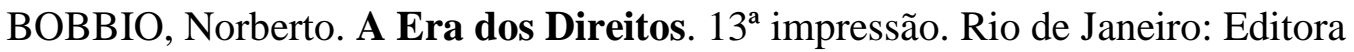
Campus, 1992.

O futuro da democracia. São Paulo: Paz e Terra, 2000.

BOSCHETTI, Ivanete. Assistência Social no Brasil: um direito entre a originalidade e conservadorismo. $2^{a}$ edição. Brasília: GESST/SER/UnB, 2003.

" "As Forças de Apoio e de Oposição à Primeira Proposta de Regulamentação da Assistência Social no Brasil". In: Cadernos do CEAM - Centro de Estudos Avançados Multidisciplinares -, ano III, nº 11, UnB, Brasília, 2002.

BOURDIEU, Pierre. "A construção do objeto". In: BOURDIEU, Pierre et alii. O Oficio do Sociólogo. Rio de Janeiro: Vozes, 2004.

BRAGA. José Luiz. "Circuitos versus campos sociais”. In: MATTOS, Maria Ângela; JUNIOR, Jeder Janotti; JACKS, Nilda (orgs.). Mediação \& Midiatização. Salvador. EDUFBA; Brasília; Compós, 2012.

BRANDÃO, Elizabeth. Comunicação Pública. Texto apresentado no XXI Congresso Brasileiro de Ciências da Comunicação. Recife, 1998. (mimeo)

Usos e significados do conceito de comunicação pública. Anais do VI

Encontro dos Núcleos de Pesquisa da Intercom, 2006. Disponível em: <http://www.portcom.intercom.org.br/pdfs/38942022201012711408495905478367291 786.pdf>. Acesso em: 27 jan. 2016.

" "Conceito de comunicação pública". In: DUARTE, Jorge. Comunicação

Pública: Estado, Mercado, Sociedade e Interesse Público. 2ª ed. São Paulo: Atlas, 2009.

BRIGGS, Asa \& BURKE, Peter. Uma História Social da Mídia: De Gutenberg à Internet. Rio de Janeiro: Jorge Zahar Editora, 2006.

CAPPARELLI, Sérgio \& LIMA, Venício A. Comunicação e Televisão: desafios da Pós-Globalização. São Paulo: Hacker, 2004.

CARNOY, Martin. Estado e Teoria Política. 16a ed. São Paulo: Papirus, 1986.

CARVALHO, José Murilo. Cidadania no Brasil. 16ª ed. Rio de Janeiro: Civilização Brasileira, 2013.

CARVAlHO, Maria do Carmo Brant; NETTO, José Paulo. Cotidiano: Conhecimento e Crítica. $5^{\text {a }}$ ed. São Paulo: Cortez, 2000.

CASTELO, Rodrigo. O novo-desenvolvimentismo e a decadência ideológica do pensamento econômico brasileiro. Revista Serviço Social e Sociedade, n. 112, out./dez. 2012. 
A Questão Social na origem do capitalismo: pauperismo e luta operária na teoria social de Marx e Engels. Dissertação (Mestrado em Serviço Social) - Programa de Pós-Graduação em Serviço Social, Centro de Filosofia e Ciências Humanas, Universidade Federal do Rio de Janeiro - UFRJ, Rio de Janeiro, 2006.

CASTELLS, Manuel. Internet e sociedade em rede. In: Por uma outra Comunicação. Dênis Moraes (org.). 4ª edição. Rio de Janeiro: Record, 2009.

A Sociedade em Rede. A Era da Informação: economia, sociedade e cultura, volume 1. São Paulo: Paz e Terra, 1999.

A sociedade em rede: do conhecimento à política. In CASTELLS, Manuel; CARDOSO, Gustavo. A sociedade em rede: do conhecimento à acção política. Portugal. Conferência promovida pela Presidência da República. Imprensa Nacional, Casa da Moeda: Debates 4, 2005.

CASTRO, Iêda Maria Nobre de. Assistência Social e cultura política: os efeitos do Sistema único de Assistência Social na construção da cultura do direito: estudo de caso sobre Fortaleza e Sobral - Ceará. Tese (Doutorado em Políticas Sociais) - Departamento de Serviço Social do Instituto de Ciências Humanas, Universidade de Brasília, Brasília. 2015.

CHAUÍ, Marilena. Cultura e democracia. São Paulo: Cortez. 10ª edição, 2003. Brasil: Mito Fundador e sociedade autoritária. São Paulo: Fundação Perseu Abramo, 2000.

COIMBRA, M. A.” Será que o marxismo responde à pergunta de como surgem as políticas sociais?" In: ABRANCHES, S. et alii. Política Social e combate à pobreza. Rio de Janeiro: Zahar, 1987.

COUTINHO, Carlos Nelson. Contra a Corrente: ensaios sobre democracia e socialismo. São Paulo: Cortez, 2000.

COUTO, B. R. O direito social e a Assistência Social brasileira: uma equação possível? São Paulo: Cortez, 2004.

DEMO, Pedro. Metodologia Científica em Ciências Sociais. $3^{\text {a }}$ ed. São Paulo: Editora Atlas, 1995.

DUARTE, Jorge. "Instrumentos de Comunicação Pública". In: Comunicação

Pública: Estado, Mercado, Sociedade e Interesse Público. 2a ed. São Paulo: Atlas, 2009.

VERAS, Luciara (org.). Glossário de Comunicação Pública. Brasília: Casa das Musas, 2006. Atlas, 2005.

BARROS, A. Métodos e técnicas de pesquisa em comunicação. São Paulo: 
DRAIBE, Sônia. A política social no período FHC e o sistema de proteção social. Revista Tempo Social, v. 15, USP, São Paulo, nov. 2003.

FALEIROS, Vicente P. Natureza e desenvolvimento das políticas sociais. Cadernos de Capacitação em Serviço Social e Política Social. Módulo 3. Brasília: UnB, 2000.

A política social do Estado Capitalista. São Paulo: Cortez, $3^{a}$ ed., 1980.

FERREIRA, Luciene Braz; Torrecilha, Nara; MACHADO, Samara Haddad Simões. A Técnica de observação em estudos de administração. XXXVI Encontro da ANPAD. Rio de Janeiro, 2012. Disponível em:

<http://www.anpad.org.br/admin/pdf/2012_EPQ482.pdf>. Acesso em: 7 nov. 2015.

FIGUEIREDO, Kênia Augusta. Novos desafios para o Serviço Social na era das comunicações. Dissertação (Mestrado em Serviço Social) - Programa de Mestrado da Escola de Serviço Social da Universidade Estadual do Rio de Janeiro, 2005. (mimeo)

. "O assistente social na era das comunicações". In: SALES, Mione Apolinário; RUIZ, Jefferson Lee de Souza (orgs.). Mídia, Questão Social e Serviço Social. $2^{a}$ ed. São Paulo: Cortez, 2010.

FILHO, Paulo Celestino da Costa. Jornalismo Público: por uma nova relação com os públicos. Revista Organicom, ano 3, n. 4, São Paulo, USP, 2006.

FLICK, Uwe. Introdução à pesquisa qualitativa. $3^{\text {a }}$ ed. Porto Alegre: Artmed, 2009.

FREIRE, Paulo. Extensão ou Comunicação? 12ª ed. São Paulo: Paz e Terra, 2002.

Pedagogia do Oprimido. 17ª ed. Rio de Janeiro: Paz e Terra. 1987.

GIL, Antonio Carlos. Métodos e Técnicas de Pesquisa Social. 5 ed. São Paulo: Atlas, 1999.

FRIGOTTO, Gaudêncio. O enfoque da dialética materialista histórica na pesquisa educacional. In: FAZENDA, Ivani (org.). Metodologia da pesquisa educacional. $10^{\mathrm{a}}$ ed. São Paulo: Cortez, 2006. p. 69-90.

GOMES, Raimunda Aline Lucena. A comunicação como direito humano: um conceito em construção. Dissertação (Mestrado em Comunicação Social) - Programa de Pós-Graduação do Centro de Artes e Comunicação da Universidade Federal de Pernambuco - UFPE, 2007.

GRANEMANN, Sara. "O processo de produção e reprodução social: trabalho e sociabilidade”. In: CFESS/ABEPSS. Serviço Social: direitos sociais e competências profissionais. Brasília, 2009.

GRAMSCI, Antonio. Cadernos do Cárcere. Volume 3. Edição e tradução: Carlos Nelson Coutinho. Coedição: Luiz Sérgio Henriques e Marco Aurélio Nogueira. Rio de Janeiro: Civilização Brasileira, 2001. 
Cadernos do Cárcere. Volume 4. Edição e tradução: Carlos Nelson Coutinho. Coedição: Luiz Sérgio Henriques e Marco Aurélio Nogueira. Rio de Janeiro: Civilização Brasileira, 2001.

HALL, Stuart. A identidade cultural na pós-modernidade. Rio de Janeiro: DP\&A, 2006.

HARVEY, David. Condição Pós-Moderna. São Paulo: Loyola, 1993.

HASWANI, Mariângela. "O discurso obscuro da lei”. In: MATOS, Heloiza (org.). Comunicação pública: interlocuções, interlocutores e perspectivas. São Paulo: ECA/USP, 2013.

Comunicação Governamental: em busca de um alicerce teórico para a realidade brasileira. Revista Organicom, ano 3, n. 4. São Paulo: USP, 2006.

HEGEL, Georg W. Friedrich. Fenomenologia do espírito. trad. Paulo Meneses. Petrópolis: Vozes, 1992.

IAMAMOTO, Marilda Villela. Serviço Social em tempos de capital fetiche: capital financeiro trabalho e questão social. São Paulo: Cortez, 2007.

CARVALHO, Raul. Relações Sociais e Serviço Social no Brasil. 15ª ed. São

Paulo: Cortez, 2003.

O Serviço Social na contemporaneidade: trabalho e formação profissional. $5^{\text {a }}$ ed. São Paulo: Cortez, 2001.

IANNI, Octávio. A sociedade global. Rio de Janeiro: Civilização Brasileira, 1992.

JAPIASSÚ, Hilton; MARCONDES, Danilo. Dicionário Básico de Filosofia. Rio de Janeiro: Jorge Zahar, 1996.

KATZ, James E.; RICE, Ronald E.; ACORD, Sophia. Usos da internet e de tecnologias móveis nos sistemas de saúde: abordagens sociais e organizacionais num contexto comparativo. In: CASTELLS, Manuel; CARDOSO, Gustavo (orgs.). A sociedade em rede: do conhecimento à acção política. Portugal. Conferência promovida pela Presidência da República. Imprensa Nacional, Casa da Moeda: Debates 4, 2005.

KERLINGER, F.N. "Problemas, Hipóteses e variáveis". In: Metodologias da pesquisa em Ciências Sociais. São Paulo: EPU, 2007.

KOÇOUSKI, Marina. "Comunicação pública: construindo um conceito”. In: MATOS, Heloiza (org.). Comunicação pública: interlocuções, interlocutores e perspectivas. São Paulo: ECA/USP, 2013.

KONDER, Leandro. O que é dialética. $8^{\text {a }}$ ed. São Paulo: Brasiliense, 1984.

KOSIK, Karel. Dialética do Concreto. Rio de Janeiro: Paz e Terra, 1995. 
KUNSCH, Margarida M. Krohling. Comunicação pública: direitos de cidadania, fundamentos e práticas. In: MATOS, Heloiza (org.). Comunicação pública: interlocuções, interlocutores e perspectivas. São Paulo: ECA/USP, 2013.

LARA, Maurício. As sete portas da comunicação pública: como enfrentar os desafios de uma assessoria. Belo Horizonte: Gutenberg, 2003.

LESSA, Sérgio. Lukács e a Ontologia: uma introdução. Revista Outubro, São Paulo, ed. 5, 2006. Disponível em: <http://outubrorevista.com.br/wpcontent/uploads/2015/02/Revista-Outubro-Edic\%CC\%A7a\%CC\%83o-5-Artigo06.pdf>. Acesso em: 26 jan. 2016.

LIMA, Venício A. de. Mídia, Teoria e Política. $2^{\text {a }}$ ed. São Paulo: Fundação Perseu Abramo, 2004.

. Liberdade de expressão x liberdade de imprensa. Direito à comunicação e a democracia. São Paulo: Publisher Brasil, 2010.

Política de Comunicações: um balanço dos governos Lula (2003-2010). São Paulo: Publisher Brasil, 2012.

Comunicação e Cultura: as ideias de Paulo Freire. São Paulo: Fundação Perseu Abramo, 2011.

A comunicação como direito fundamental. Observatório da Imprensa. Ed. 770, de 29 out. 2013. Disponível em: <http://observatoriodaimprensa.com.br/armazemliterario/_ed770_a_comunicacao_como_direito_fundamental/>. Acesso em: 22 jan. 2016.

LÖWY, Michael. Ideologias e Ciência Social: elementos para uma análise marxista. 19a ed. São Paulo: Cortez, 2010.

MALINA, André. O Método Dialético e a Escola. Disponível em:

<http://cev.org.br/biblioteca/o-metodo-dialetico-e-escola/>. Acesso em: 21 jan. 2016.

MANDEL, Ernest. O capitalismo tardio. São Paulo: Abril Cultural, 1985.

MARQUES, José de Melo; SATHLER, L. Direitos à Comunicação na Sociedade da informação. São Bernardo do Campo: Umesp, 2005.

MARSHALL, T.H. Cidadania, classe social e status. Rio de Janeiro: Jorge Zahar, 1967.

MARTÍN-BARBERO, Jesús. Dos meios às mediações: comunicação, cultura e hegemonia. $7^{\mathrm{a}}$ ed. Rio de Janeiro: Editora UFRJ, 2013.

MATTELART, Armand e Michèlle. História das Teorias da Comunicação. $7^{\mathrm{a}}$ ed. São Paulo: Edições Loyola, 2004. 
MATOS, Heloiza Helena Gomes. Comunicação Política e Comunicação Pública. Revista Organicom, ano 3, n. 4, USP, São Paulo, 2006.

“Comunicação pública, esfera pública e capital social”. In. DUARTE, Jorge. Comunicação Pública: Estado, Mercado, Sociedade e Interesse Público. $2^{a}$ ed. São Paulo: Atlas, 2009a.

A Comunicação Pública no Brasil e na França: desafios conceituais. Anais XXXII Congresso Brasileiro de Ciências da Comunicação. Intercom - Sociedade Brasileira de Estudos Interdisciplinares da Comunicação XXXII Congresso Brasileiro de Ciências da Comunicação - Curitiba, PR - 4 a 7 de setembro de 2009 IX Colóquio Brasil-França de Ciências da Comunicação, 2009b. Disponível em: <http://www.intercom.org.br/papers/nacionais/2009/resumos/R4-3060-1.pdf>. Acesso em: 26 jan. 2016.

; GIL, Patrícia Guimarães. “Quem é o cidadão na comunicação pública?” In: MATOS, Heloisa (org.). Comunicação pública: interlocuções, interlocutores e perspectivas. São Paulo: ECA/USP, 2013.

MEDITSCH, Eduardo. Teorias do Rádio: Textos e Contextos. Volume 1. Florianópolis: Insular, 2005.

MELUCCI, Alberto. Challenging codes: collective action in the information age. Cambridge: University Press, 1996.

MINAYO, Maria Cecilia de Souza (org.). Pesquisa Social, Teoria, método e criatividade. $22^{\mathrm{a}}$ ed. Rio de Janeiro: Vozes, 2003.

MONTEIRO, Graça França. A singularidade da Comunicação Pública. In. DUARTE, Jorge. Comunicação Pública: Estado, Mercado, Sociedade e Interesse Público. $2^{a}$ ed. São Paulo: Atlas, 2009.

MORAES, Dênis. "Gramsci e as mutações do visível: comunicação e hegemonia no tempo presente". In: . Mutações do visível: da comunicação de massa à comunicação em rede. Rio de Janeiro: Pão e Rosas, 2010.

MOTA, Ana Elisabete. "Crise capitalista e as transformações na produção capitalista". In: CFESS/ABEPSS. Serviço Social: direitos sociais e competências profissionais. Brasília, 2009.

MURTINHO, Rodrigo de Martinez Torres. Estado, comunicação e cidadania: diálogos pertinentes sobre a relação entre direito à saúde e direito à comunicação. Tese (Doutorado em Comunicação Social) - Programa de Pós-Graduação do Instituto de Arte e Comunicação Social da Universidade Federal Fluminense, 2012.

NAPOLITANO, Carlos José. A regulação Jurídica da comunicação social na Constituição de 1988. Intercom - Sociedade Brasileira de Estudos Interdisciplinares da Comunicação. XXXIV Congresso Brasileira de Ciências da Comunicação - Recife, PE - 2 a 6 de setembro de 2011. 
Disponível em: <http://www.intercom.org.br/papers/nacionais/2011/resumos/R6-19011.pdf $>$. Acesso em: 31 ago. 2015.

NETTO, José Paulo. Democracia e transição socialista: escritos de teoria e política. Belo Horizonte: Oficina de Livros, 1990.

. Transformações societárias e Serviço Social. Serviço Social e Sociedade, n. 50, ed. Cortez, São Paulo, 1996.

2011.

Introdução ao estudo do método de Marx. São Paulo: Expressão Popular,

Capitalismo Monopolista e Serviço Social. 5a ed. São Paulo: Cortez, 2006.

NEVES, Ângela Vieira. Cultura Política e Democracia Participativa: Um estudo sobre o orçamento participativo. Rio de Janeiro: Gramma, 2008.

NOGUEIRA, Marco Aurélio. As possibilidades da política: ideias para a reforma democrática do Estado. São Paulo: Paz e Terra, 1998.

A dialética Estado/Sociedade e a construção da Seguridade Social pública. In:

Cadernos ABONG, n. 30. São Paulo, 2001.

NOVELLI, Ana Lucia Coelho Romero. O papel institucional da Comunicação pública para o sucesso da governança. Revista Organicom, ano 3, n. 4, USP, São Paulo, 2006.

OLIVEIRA, Heloisa Maria José de. Cultura Política e Assistência Social: uma análise das orientações dos gestores estaduais. São Paulo: Cortez, 2003.

OLIVEIRA, Maria José da Costa. "Comunicação Pública e os setores não estatais". In: OLIVEIRA, Maria José da Costa. Comunicação Pública. Campinas: Alínea, 2004.

OSTROWER, Fayga. Criatividade e processos de criação. 17ª ed. Petrópolis: Vozes, 1987.

PAULA, Renato Francisco dos Santos. Serviço Social, Estado e desenvolvimento capitalista: (im)possibilidades neodesenvolvimentistas e projeto profissional. Tese (Doutorado em Serviço Social) - Programa de Estudos Pós-Graduados em Serviço Social, Pontifícia Universidade Católica de São Paulo, São Paulo, 2013.

PEREIRA, Larissa Dahmer. Educação e Serviço Social: do confessionalismo ao empresariamento da formação profissional. São Paulo: Xamã, 2008.

PEREIRA, Potyara Amazoneida P. Necessidades humanas: subsídios à crítica dos mínimos sociais. São Paulo: Cortez, 2000.

A Assistência Social na perspectiva dos direitos: critica aos padrões

dominantes de proteção aos pobres no Brasil. Brasília: Thesaurus, 1996. 
Utopias desenvolvimentistas e política social no Brasil. Revista Serviço Social

e Sociedade, São Paulo, n. 112, p. 729-753, out./dez. 2012.

PEREIRA, Potyara A. P. Política social: temas \& questões. $2^{\mathrm{a}}$ ed. São Paulo: Cortez, 2009.

PERUZZO, Cicilia Maria Krohling. "Direito à Comunitária, Participação Popular e Cidadania". In: OLIVEIRA, Maria José da Costa. Comunicação Pública. CampinasSP: Alínea, 2004.

Direito à comunicação comunitária, participação popular e cidadania. Lumina, v. 1, p. 1-29, 2007.

Observação participante e pesquisa ação. In: DUARTE, Jorge; BARROS, Antônio (org.). Métodos e Técnicas de Pesquisa em Comunicação. $2^{\mathrm{a}}$ ed. São Paulo: Atlas, 2012.

PONTES, Reinaldo. "Mediação: categoria fundamental para o trabalho do assistente social". In: Cfess/Abepss/Cead-UnB. Caderno de Capacitação em Serviço Social e Política Social. Módulo 4. Brasília: UnB, 2000.

Mediação e Serviço Social. $6^{a}$ ed. São Paulo: Cortez, 2009.

POUPART, Jean et alii. A pesquisa qualitativa enfoques epistemológicos e metodológicos. Rio de Janeiro: Vozes, 2008.

RAICHELES, Rachel D. Desafios da gestão democrática das Políticas Sociais. In: Cfess/Abepss/Cead-UnB. Caderno de capacitação em Serviço Social e Política Social - Módulo 3. Brasília: UnB, 2000.

RAMOS, Murilo César. Comunicação, direitos sociais e políticas públicas. In: MARQUES DE MELO, J.; SATHLER, L. Direitos à Comunicação na Sociedade da informação. São Bernardo do Campo: Unesp, 2005.

; SANTOS, Suzy dos. Políticas de Comunicação: busca teórica e práticas. São Paulo: Paulus, 2007.

RAMONET, Ignácio. O poder midiático. In: MORAES, Dênis de (org.). Por uma outra comunicação: mídia, mundialização cultural e poder. $4^{\mathrm{a}}$ ed. Rio de Janeiro: Record, 2009.

REGO, Walquiria Leão; PINZANI, Alessandro. Vozes do Bolsa Família Autonomia, dinheiro e cidadania. São Paulo: Editora Unesp, 2013.

RODRIGUES, João Antonio. A teoria social de Marx e o Serviço Social. Revista Serviço Social e Realidade, v. 12, n. 1, Unesp, Franca, 2003. (mimeo)

RUIZ, Jefferson Lee de Souza. Comunicação como direito humano. In: SALES, Mione Apolinário; RUIZ, Jefferson Lee de Souza (org.). Mídia, Questão Social e Serviço Social. $2^{\mathrm{a}}$ ed. São Paulo: Cortez, 2010. 
SALES, Mione Apolinário. Cidadania das Famílias, Direitos de Crianças e Adolescentes: O Desafio da Assistência Social. Publicação do Conselho Federal de Serviço Social. Brasília, 2002.

SANTOS, Claudia Mônica dos. Na prática a teoria é outra? Mitos e dilemas na relação entre teoria, prática, instrumentos e técnicas no Serviço Social. Rio de Janeiro: Lumen Juris, 2010.

SANTOS, Josiane Soares. Neoconservadorismo Pós-moderno e Serviço Social brasileiro. São Paulo: Cortez, 2007. Coleção Questões da Nossa Época.

SANTOS, Milton. O Espaço Cidadão. $4^{a}$ ed. São Paulo: Nobel, 1998.

Por uma outra globalização: do pensamento único à consciência universal. $6^{\mathrm{a}}$ ed. São Paulo: Editora Record, 2005.

SANTOS, Wanderley Guilherme. Cidadania e Justiça. $3^{\text {a }}$ ed. Rio de Janeiro: Campus, 1994.

SARAIVA, Enrique; FERRAREZI, Elizabete (org.). Políticas Públicas. Coletânea Volume 1. Escola Nacional de Administração Pública. Brasília, 2006.

SARDINHA, Antônio Carlos. Comunicação, controle social das políticas públicas e os desafios para a Comunicação Pública nos conselhos gestores de saúde. Revista e-Com, vol. 5, n. 1, 2012. Disponível em:

<http://revistas.unibh.br/index.php/ecom/article/view/803/447>. Acesso em: 5 ago. 2013.

SARLO, Beatriz. Cenas da Vida Pós-Moderna: Intelectuais, arte e videocultura na Argentina. Rio de Janeiro: UFRJ, 2006.

SEMERARO, Giovanni. Cultura e Educação para a democracia: Gramsci e a sociedade civil. Petrópolis: Vozes, 1999.

SILVA, Juremir M. O que pesquisar quer dizer. Porto Alegre: Bookman, 2001. (mimeo)

SILVA, Marta Borba. Assistência Social e seus usuários - entre a rebeldia e o conformismo. São Paulo: Cortez. 2014.

SIMIONATTO, Ivete. Gramsci: sua teoria, incidência no Brasil, influência no Serviço Social. $3^{\text {a }}$ ed. São Paulo: Cortez, 2004.

SODRÉ, Muniz. O Globalismo como neobarbárie. In: MORAES, Dênis (org.). Por uma outra Comunicação. $4^{\mathrm{a}}$ ed. Rio de Janeiro: Editora Record, 2009.

SPOSATI, Aldaiza. Assistência x Assistencialismo x Assistência Social. In:

CNAS/ABONG. I Conferência Nacional de Assistência Social. Brasília:

CNAS/ABONG/apoio UNICEF, 1995. 
SUBIRATS, Joan; KNOEPFEL, Peter; LARRUE, Corinne; VARONE, Frederic. Análisis y gestión de políticas públicas. Ariel. Barcelona, 2008.

TAVARES, Maria Augusta. "Acumulação, trabalho e desigualdades sociais". In: CFESS/ABEPSS. Serviço Social: direitos sociais e competências profissionais. Brasília, 2009.

TEIXEIRA, Sônia Fleury. Assistência na Previdência Social: uma política marginal. In VV. AA. Os direitos (dos desassistidos) sociais. São Paulo: Cortez, 1989.

THOMPSON, John B. A Mídia e a Modernidade. Uma teoria social da mídia. Petrópolis: Vozes, 1998.

TOMANIK, Eduardo Augusto. O olhar no espelho: conversas sobre a pesquisa em ciências sociais. $2^{\mathrm{a}}$ ed. revisada. Maringá: Eduem, 2004.

TONET, Ivo. Método Científico, uma abordagem ontológica. São Paulo: Instituto Lukács, 2013.

TORRES, Iraildes Caldas Torres. As primeiras damas e a Assistência Social: relações de gênero e poder. São Paulo: Editora Cortez, 2002.

TRAVANCAS, Isabel. Fazendo etnografia no mundo da comunicação. In: Métodos e Técnicas de Pesquisa em Comunicação. DUARTE, Jorge; BARROS, Antônio (org.). $2^{a}$ edição. São Paulo: Atlas, 2012.

WELS, Ana Maria Córdova. Estudo sobre assessorias de comunicação social na esfera pública estadual: práticas profissionais e processo comunicacional. Revista Organicom, ano 3, n. 4, USP, São Paulo, 2006.

WILLIAMS, Raymond. Cultura e Sociedade: de Coleridge a Orwell. Petrópolis: Vozes, 2011.

WIMMER, Miriam. Direitos, democracia e acesso aos meios de comunicação de massa. Tese (Doutorado em Comunicação Social) - Faculdade de Comunicação da Universidade de Brasília, 2012.

WOLTON, Dominique. Informar não é comunicar. Porto Alegre: Sulinas, 2011.

YASBEK, Maria Carmelita. Classes Subalternas e Assistência Social. $4^{\mathrm{a}}$ ed. São Paulo: Cortez, 2003.

Pobreza no Brasil contemporâneo e formas de seu enfrentamento. Revista Serviço Social e Sociedade, São Paulo, n. 110, p. 288-322, abr./jun. 2012.

ZÉMOR, Pierre. La Comunication Publique. PUF, Col. Que sais-je? Paris, 1995. Tradução de Elizabeth Brandão. Impressão eletrônica, 2005. Disponível em: <https://comunicacaopublicaufes.files.wordpress.com/2011/12/comunicacaopublicapierrezemor-traducao.pdf>. Acesso em: 22 jan. 2016. 
As formas da Comunicação Pública. In: DUARTE, Jorge. Comunicação

Pública: Estado, Mercado, Sociedade e Interesse Público. 2a ed. São Paulo: Atlas, 2009. 


\section{Documentos oficiais:}

BRASIL. Censo SUAS 2014 - Resultados Nacionais, Secretarias Municipais de Assistência Social, Gestão Municipal. Brasília, Coordenação Geral de Vigilância Socioassistencial. Secretaria Nacional de Assistência Social. Ministério do Desenvolvimento Social e Combate à Fome. Abril de 2015. (Mimeo)

BRASIL. Censo SUAS 2014 - Resultados Nacionais, Centros de Referência da Assistência Social, CRAS. Brasília, Coordenação Geral de Vigilância Socioassistencial. Secretaria Nacional de Assistência Social. Ministério do Desenvolvimento Social e Combate à Fome. Abril de 2015. (Mimeo)

BRASIL. Comissão Intergestores Tripartite. Protocolo de Gestão Integrada de Serviços, Benefícios e Transferências de Renda no âmbito do Sistema Único de Assistência Social - SUAS (Resolução nº 7, de 10 de setembro de 2009). Brasília: MDS, 2009.

BRASIL. Conselho Nacional de Assistência Social. Tipificação Nacional de Serviços Socioassistenciais (Resolução n. 109, de 11 de novembro de 2009). Brasília: MDS, 2009.

BRASIL. Conselho Nacional de Assistência Social. Resolução n ${ }^{\circ} 11$ de 23 de setembro de 2015. Caracteriza os usuários, seus direitos e sua participação na Política Pública de Assistência Social e no Sistema Único de Assistência Social, e revoga a Resolução $n^{\circ}$ 24, de 16 de fevereiro de 2006. Brasília: MDS, 2015.

BRASIL. Constituição da República Federativa do Brasil. Brasília: Senado Federal, 1988.

BRASIL. Dialoga Brasil. Site do governo Federal. Disponível em: <http://dialoga.gov.br/\#/artigo/108073>. Acesso em: 27 jan. 2016.

BRASIL. Ministério do Desenvolvimento Social e Combate à Fome. Jornal MDS, $\mathrm{n}^{\circ}$ 26, 2010.

BRASIL. Lei Orgânica da Assistência Social. Lei no ${ }^{\circ}$ 8.742, de 7 de dezembro de 1993. Brasília: Senado Federal, 1993.

BRASIL. Lei Orgânica da Assistência Social. Lei nº 12.435, de 6 de julho de 2011. Brasília: Senado Federal, 2011.

BRASIL. Ministério do Desenvolvimento Social e Combate à Fome. Orientações Técnicas: Centro de Referência de Assistência Social - Cras. Brasília: MDS, 2012.

BRASIL. Ministério do Desenvolvimento Social e Combate à Fome. Política Nacional de Assistência Social (PNAS). Brasília: MDS, 2004. 
BRASIL. Ministério do Desenvolvimento Social e Combate à Fome. Política Nacional de Assistência Social (PNAS). Norma Operacional Básica de Recursos Humanos do SUAS (NOB/RH). Brasília: MDS, 2006.

BRASIL. Ministério do Desenvolvimento Social e Combate à Fome. Secretaria Nacional de Assistência Social (SNAS). Proteção Básica do Sistema Único de Assistência Social. Orientações para o acompanhamento das famílias beneficiárias do Programa Bolsa Família no âmbito do Suas. Brasília, 2006.

BRASIL. Ministério do Desenvolvimento Social e Combate à Fome. Secretaria Nacional de Assistência Social (SNAS). Slides sobre o organograma MDS. Decreto $\mathrm{n}^{\circ}$ 7.493, de 2 de junho de 2011.

BRASIL. Ministério do Desenvolvimento Social e Combate à Fome. Secretaria Nacional de Assistência Social (SNAS). Orientações Técnicas sobre o Paif. Volume 1. O Serviço de Proteção e Atendimento Integral à Família (Paif), segundo a Tipificação Nacional de Serviços Socioassistenciais. 1ª edição. Brasília, 2012.

BRASIL. Ministério do Desenvolvimento Social e Combate à Fome. Secretaria Nacional de Assistência Social (SNAS). Orientações Técnicas sobre o Paif. Volume 2. Trabalho Social com Famílias do Serviço de Proteção e Atendimento Integral à Família (Paif). $1^{\text {a }}$ edição. Brasília, 2012.

BRASIL. Ministério do Desenvolvimento Social e Combate à Fome. Política Nacional de Assistência Social (PNAS). Norma Operacional Básica (NOB/Suas). Brasília: MDS, 2005.

BRASIL. Instituto Brasileiro de Geografia e Estatística. Censo 2010. Disponível em: <http://censo2010.ibge.gov.br/>. Acesso em: 28 jan. 2016.

BRASIL. Ministério do Desenvolvimento Social e Combate à Fome. Relatório de Gestão de 2014. Disponível em:

<http://www.mds.gov.br/bolsafamilia/RelatorioGestao2014.pdf.pagespeed.ce.t0LhupiRB.pdf $>$. Acesso em: 22 jan. 2016.

MNDH. Carta de Brasília - Encontro Nacional de Direitos Humanos. Brasília: Câmara dos Deputados, 2005. Disponível em: <http://www2.camara.leg.br/atividadelegislativa/comissoes/comissoes-ermanentes/cdhm/noticias/endh_cartabrasilia $>$. Acesso em: 10 fev. 2014.

\section{Fontes de Jornais online}

Governo federal desmente boato sobre suspensão do Bolsa Família. G1, Brasília, 18 mai. 2013. Caderno Brasil. Disponível em: <http://g1.globo.com/brasil/noticia/2013/05/governo-federal-desmente-boato-sobresuspensao-do-bolsa-familia.html>. Acesso em 19 mai. 2013.

GAMA, Aliny. Boato Boato sobre fim do Bolsa Família causa confusão e tumulto em Estados do Nordeste. UOL, Maceió, 19 mai. 2013. Disponível em:

$<$ http://noticias.uol.com.br/cotidiano/ultimas-noticias/2013/05/19/boato-sobre-fim-do- 
bolsa-familia-causa-confusao-e-tumulto-em-estados-do-nordeste.htm>. Acesso em: 19 mai. 2013.

PF vai investigar boato sobre suspensão do Bolsa Família. UOL, Maceió, 19 mai. 2013. Disponível em: <http://noticias.uol.com.br/cotidiano/ultimasnoticias/2013/05/19/pf-vai-investigar-boato-sobre-suspensao-do-bolsa-familia.htm>. Acesso em: 20 mai. 2013.

GUIDU, Fábio. SÁ, Danilo. Em AL, boato sobre fim do Bolsa Família correu entre vizinhos. Folha de S.Paulo, Recife e Natal, 20/05/2013. <http://www1.folha.uol.com.br/poder/2013/05/1281666-em-al-boato-sobre-fim-dobolsa-familia-correu-entre-vizinho.shtml>. Acesso em: 20 mai. 2013.

Com boato, 900 mil beneficiários do Bolsa Família sacaram R $\$ 152$ milhões - Rio está entre os estados que mais registrou movimentação nas agências durante o fim de semana. O Globo, Rio de Janeiro, 20 mai. 2013. Disponível em: <http://oglobo.globo.com/brasil/com-boato-900-mil-beneficiarios-do-bolsa-familiasacaram-152-milhoes-8440894>. Acesso em: 20 mai. 2013.

Boato faz Caixa Econômica antecipar 900 mil benefícios do Bolsa Família.

RiachãoNet, Picos, 20 mai. 2013. Disponível em: <http://www.riachaonet.com.br/boato-faz-caixa-economica-antecipar-900-milbeneficios-do-bolsa-familia/>. Acesso em: 20 mai. 2013.

TELES, Giovana. Boato sobre fim do Bolsa Família leva 900 mil pessoas a agências da CEF. G1, Bom Dia Brasil, Brasília, 21 mai. 2013. Disponível em: $<$ http://g1.globo.com/bom-dia-brasil/noticia/2013/05/boato-sobre-fim-do-bolsa-familialeva-900-mil-pessoas-agencias-da-cef.html>. Acesso em: 21 mai. 2013.

TALENTO, Aguirre. Carvalho, Daniel. Caixa alterou Bolsa Família na véspera de boato sobre programa. Folha de S.Paulo, Fortaleza e São Paulo, 25 mai. 2013. Disponível em: <http://www1.folha.uol.com.br/poder/2013/05/1284718-caixa-alterou-bolsafamilia-na-vespera-de-boato-sobre-programa.shtml>. Acesso em: 25 mai. 2013.

MAGALHÃES, Vera. Caixa reconhece ter cometido erro no caso do Bolsa Família. Banco mudou pagamento um dia antes de boato, mas omitiu informação. Folha de S.Paulo, São Paulo, 28 mai. 2013. Caderno Poder. Disponível em: <http://www1.folha.uol.com.br/fsp/poder/111185-caixa-reconhece-ter-cometido-errono-caso-do-bolsa-familia.shtml>. Acesso em: 28 mai. 2013.

LEITÃO, Matheus. Pagamento antecipado vira foco de inquérito da PF sobre Bolsa Família. Para agentes, liberação de beneficio pela Caixa é principal linha de investigação dos boatos. Folha de S.Paulo, Brasília, 4 jun. 2013. Caderno Poder. Disponível em: <http://www1.folha.uol.com.br/poder/2013/06/1289341-pagamentoantecipado-vira-foco-de-inquerito-da-pf-sobre-bolsa-familia.shtml>. Acesso em: 4 jun. 2013.

MACEDO, Fausto. Policia Federal conclui que boato do Bolsa Família foi espontâneo. O Estado de S.Paulo, São Paulo, 12 jul. 2013. Disponível em: 
<http://politica.estadao.com.br/noticias/geral,policia-federal-conclui-que-boato-dobolsa-familia-foi-espontaneo,1052863>. Acesso em: 12 de jul. 2013.

PF conclui que boato sobre fim do Bolsa Família foi espontâneo. G1, São Paulo, 12 jul. 2013. Disponível em: <http://g1.globo.com/politica/noticia/2013/07/pf-conclui-queboato-sobre-fim-do-bolsa-familia-foi-espontaneo-1.html>. Acesso em: 13 jul. 2013.

SIMÕES, Eduardo. PF conclui que boato sobre fim do Bolsa Família foi espontâneo. Terra, 12 jul. 2013. Disponível em: <http://noticias.terra.com.br/brasil/politica/pfconclui-que-boato-sobre-fim-do-bolsa-familia-foiespontaneo,42995a236f3df310VgnCLD2000000dc6eb0aRCRD.html>. Acesso em: 13 jul. 2013.

COUTINHO, Filipe. Magalhães, João Carlos. Caixa antecipou pagamento do Bolsa Família sem licença. Folha de S.Paulo, Brasília, 16 jul. 2013. Caderno Poder. Disponível em: <http://www1.folha.uol.com.br/poder/2013/07/1311596-caixaantecipou-pagamento-do-bolsa-familia-sem-licenca.shtml>. Acesso em: 16 de jul. 2013. 


\section{ANEXOS \\ Anexo 1 \\ Roteiro de entrevista dos usuários da Assistência Social ${ }^{97}$}

1. Por que você procurou o Cras? O que estava procurando no Cras?

2. Como soube que seria no Cras o atendimento para o seu problema? Qual era o seu pedido/demanda?

3. O que te trouxe aqui foi resolvido? Como?

4. O que você achou do atendimento? O pessoal entendeu ou conseguiu resolveu o seu problema?

6. Pra você o que é o Cras? E o que é Assistência Social? Que importância tem esse lugar pra você e sua família?

7. Você já recebeu folhetos, algum material com informação aqui no Cras? O que dizia? Foi útil?

8. Você lê os materiais pregados no Cras? O que dizem?

9. Qual poderia ser a melhor forma do Cras comunicar com você?

10. Novas mídias:

- Você usa de celular? SMS; internet;

- Você tem computador em casa? Usa Lan House? Outro?

- Acessa internet para: Consulta página do Bolsa Família; Secretaria/prefeitura; ter informação/noticias; Lazer.

- Você usa rede social? Conhecer/atualizar amigos

\footnotetext{
${ }^{97}$ Este roteiro é um instrumento da pesquisa sobre comunicação pública na política de Assistência Social realizada por Kênia Augusta Figueiredo, doutoranda em Comunicação pela Universidade de Brasília.
} 
11. Como você define o que são direitos sociais.

12. Você acha que aqui você aprende coisas que são uteis para a sua vida e para os seus familiares?

13. Pra você quais são as melhores formas de comunicar com as pessoas que usam os serviços da política de Assistência Social. 


\section{Anexo 2}

\section{Roteiro de entrevista para representante de usuário no Conselho Municipal de} Assistência Social ${ }^{98}$

1. O que você espera da política de Assistência Social?

2. Como você avalia a comunicação com os usuários da política de Assistência Social?

Como percebe? Por quais meios? Em quais momentos?

3. Como seria a comunicação ideal com os usuários? E sobre o que seria? Com qual frequência?

4. Como o CMAS pode colaborar para otimizar a comunicação na política de Assistência Social? Fez-se sugestão; se já discutiu o assunto nas reuniões; se há queixas dos usuários;

5. Quais são as melhores formas de comunicar com o usuário da política de Assistência Social? Quais formas, meios, estratégias.

6. Avaliar a questão da internet, celular pelos usuários, comunicação, autocomunicação.

\footnotetext{
${ }^{98}$ Este roteiro é um instrumento da pesquisa sobre comunicação pública na política de Assistência Social realizada por Kênia Augusta Figueiredo, doutoranda em Comunicação pela Universidade de Brasília.
} 


\section{Anexo 3}

\section{Roteiro de entrevista para a equipe técnica da Assistência Social ${ }^{99}$}

Em relação a sua experiência na gestão da política de Assistência Social:

1. Como você percebe a comunicação na política de Assistência Social?

2. Como você percebe a comunicação na política de Assistência Social com o usuário da política? E como deveria ser?

3. Como vocês organizam a comunicação com os usuários da Assistência Social?

4. Há um orçamento específico para as atividades de comunicação?

5. As normativas determinam que o Paif deve: produzir material educativo; realizar campanhas; qualificar e formar usuários na perspectiva cidadã; estimular o protagonismo político e assegurar o direito a informação.

6. Como é pensado a realização destes elementos? Quem fez, quando, como?

7. De que forma? Estratégias, momentos, com qual frequência.

8. Com qual orçamento? E com qual equipe (especialidades)?

9. Os Cras devem realizar "busca ativa" e monitorar o cumprimento das condicionalidades dos usuários do PBF. Existe uma política de comunicação estruturada pra este fim? Há diretrizes, estrutura e recursos? Quais são as orientações?

10. Como você percebe a relação da mídia com a Assistência Social?

11. Como você percebe a relação que os profissionais da Assistência Social tem com o direito a comunicação?

\footnotetext{
${ }^{99}$ Este roteiro é um instrumento da pesquisa sobre comunicação pública na política de Assistência Social realizada por Kênia Augusta Figueiredo, doutoranda em Comunicação pela Universidade de Brasília.
} 


\section{Anexo 4 \\ Roteiro de entrevista para os gestores da Assistência Social ${ }^{100}$}

\section{I-Características Gerais}

1. Número de Habitantes:

2. Principais fontes de arrecadação:

3. Estrutura da política de Assistência Social:

\section{- Para os municípios:}

3.1. Número de CRAS;

3.2. Número e formação dos funcionários especializados;

3.3. Forma de contratação;

3.4. Estimativa de pessoas atendidas pela Assistência Social;

3.5. Estimativa de pessoas atendidas pela Assistência Social por dia.

\section{II - Questões reflexivas}

1. De que forma está estruturada a comunicação com os usuários da Assistência Social?

2. Com qual orçamento?

3. As normativas determinam que o PAIF deve: produzir material educativo; realizar campanhas; qualificar e formar usuários na perspectiva cidadã; estimular o protagonismo político e assegurar o direito a informação.

3.1. Como tem sido pensado a realização destes elementos?

\footnotetext{
${ }^{100}$ Este roteiro é um instrumento da pesquisa sobre comunicação pública na política de Assistência Social realizada por Kênia Augusta Figueiredo, doutoranda em Comunicação pela Universidade de Brasília.
} 
3.2. De que forma?

3.3 Com qual orçamento? E com qual equipe (especialidades)?

4. Os CRAS devem realizar "busca ativa" e monitorar o cumprimento das condicionalidades dos usuários do PBF. Existe uma política de comunicação estruturada pra este fim? Há diretrizes, estrutura e recursos? Quais são as orientações?

5. Como você percebe a comunicação na política de Assistência Social?

6. Como você percebe a comunicação na política de Assistência Social com o usuário da PNAS?

7. A mídia e a Assistência Social?

8. A comunicação e os profissionais da Assistência Social?

9. Os Instrumentos de comunicação/ capacidade de execução/ orçamento?

10. O trabalho da assessoria de comunicação na política de Assistência Social? 


\section{Anexo 5}

\section{ROTEIRO DE ENTREVISTA}

\section{ASSESSORIA DE COMUNICAÇÃO DO MDS (pesquisa exploratória)}

\section{I - DADOS PESSOAIS DA ASSESSORA DE COMUNICAÇÃO}

1-Cargo;

2-Função;

3-Formação profissional;

4- Há quanto tempo está no MDS e, em especial, na Assessoria de Comunicação.

\section{II - DADOS SOBRE A ASSESSORIA DE COMUNICAÇÃO}

1. Como foi o processo de estruturação da Assessoria de Comunicação?

Histórico da implantação: o que faz, como faz, com quais instrumentos, com quais objetivos e finalidade, publico alcançado, missão, metas e projetos.

2. Como está organizada a rotina da Assessoria de Comunicação?

Composição e número de componentes da equipe; produtos e ações (atendimento a imprensa; produção de material impresso; Rádio; TV; mídias sociais; produção de material educativo).

2.1. Quem cuida da publicidade? Quais são as orientações?

3. Quais as frentes de atuação e segmentos sociais priorizados?

4. Como é realizada a comunicação junto aos usuários?

5. Como é a realizada a comunicação com a mídia?

6. Como é monitorada a política de comunicação do MDS?

\section{III - DADOS REFLEXIVOS}

Como a assessoria compreende: 
a- A Política de Assistência Social?

b- A assessoria de comunicação para a política de Assistência Social?

c- A comunicação na política de Assistência Social?

d- O organograma do MDS?

e- A comunicação com o usuário da PNAS?

f- A mídia e a Assistência Social?

g- A comunicação e os profissionais da Assistência Social?

h- Os Instrumentos de comunicação/ capacidade de execução/ orçamento?

i- Como se dá a participação da assessoria de comunicação na Conferencia Nacional de AS? e dos profissionais da comunicação nas instâncias de debate e deliberação da PNAS; 


\section{Anexo 6}

\section{ROTEIRO DE ENTREVISTA}

\section{DIRETORIA DE IMPLANTAÇÃO DO SUAS} (pesquisa exploratória)

\section{I - DADOS PESSOAIS DA DIRETORA DE IMPLANTAÇÃO DO SUAS}

1-Cargo;

2-Função;

3-Formação profissional;

4- Há quanto tempo está no MDS e, em especial, na diretoria.

\section{II - DADOS SOBRE A DIRETORIA DE IMPLANTAÇÃO DO SUAS}

1. Como foi o processo de estruturação da diretoria de implantação do Suas? Histórico da implantação, objetivos e finalidade, missão, metas e projetos.

2. Como está organizada a rotina da diretoria de implantação do Suas?

Composição e número de componentes da equipe; produtos e atividades

\section{III - DADOS REFLEXIVOS}

1. As normativas determinam que o PAIF deve: produzir material educativo; realizar campanhas; qualificar e formar usuários na perspectiva cidadã; estimular o protagonismo político e assegurar o direito a informação.

1.1. Como tem sido pensado a realização destes elementos?

1.2. De que forma?

\subsection{Com qual orçamento?}

2. Os CRAS devem realizar "busca ativa" e monitorar o cumprimento das condicionalidades dos usuários do PBF. Existe uma política de comunicação estruturada pra este fim? Há diretrizes, estrutura e recursos? Quais são as orientações? 
3. O trabalho junto aos usuários diz respeito a articulação entre os entes federados sendo competência dos municípios a relação mais direta. Existe um monitoramento por parte do MDS da qualidade da comunicação entre poder público e usuários? Existe o registro de experiências que asseguram o direito a comunicação?

4. Como você percebe a assessoria de comunicação na política de Assistência Social?

5. A comunicação na política de Assistência Social?

6. O organograma do MDS?

7. A comunicação com o usuário da PNAS?

8. A mídia e a Assistência Social?

9. A comunicação e os profissionais da Assistência Social?

10. Os instrumentos de comunicação/capacidade de execução/orçamento? 